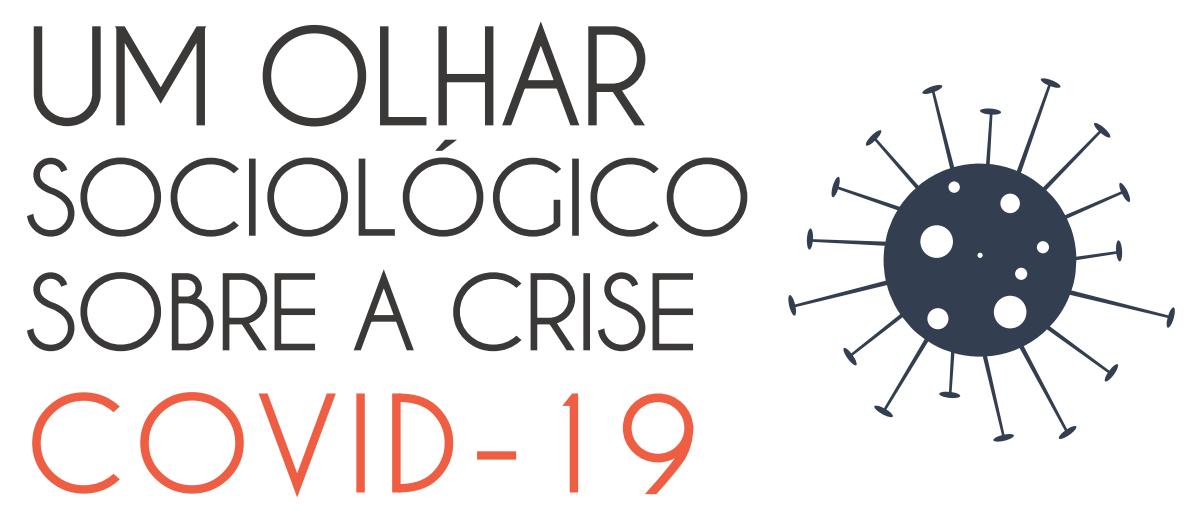

EM LIVRO

O R G A I Z A D ORES

RENATO MIGUEL DO CARMO

INÊS TAVARES

ANA FILIPA C ÂNDIDO

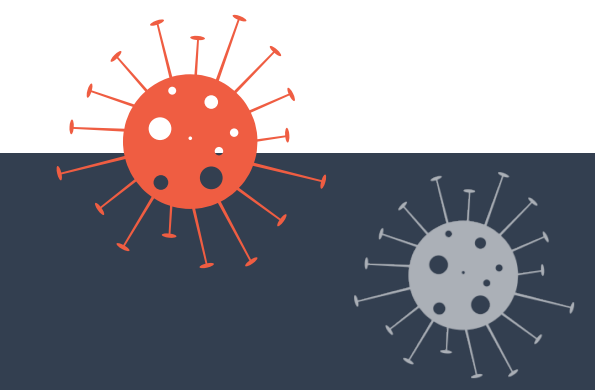

ALDA BOTELHO AZEVEDO

ANA DRAGO

ANA RAQUEL MATIAS

ANTÓNIO FIRMINO DA COSTA

FERNANDO DIOGO

FREDERICO CANTANTE

JOÃO TEIXEIRA LOPES

JOSÉ SOARES NEVES

LUISA SCHMIDT

MADALENA DUARTE

MARIA DO MAR PEREIRA

SOFIA ABOIM

SUSANA DA CRUZ MARTINS TIAGO CORREIA

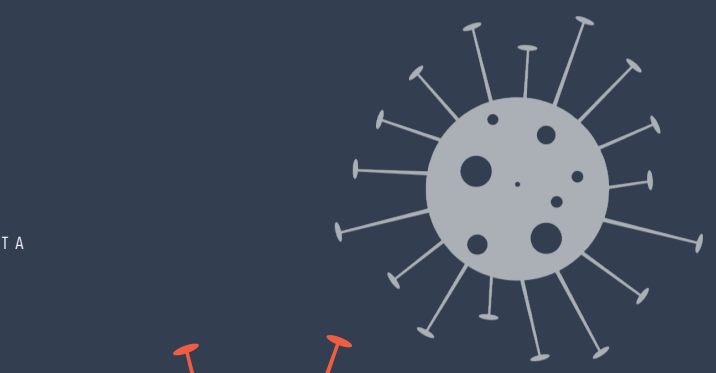

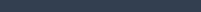

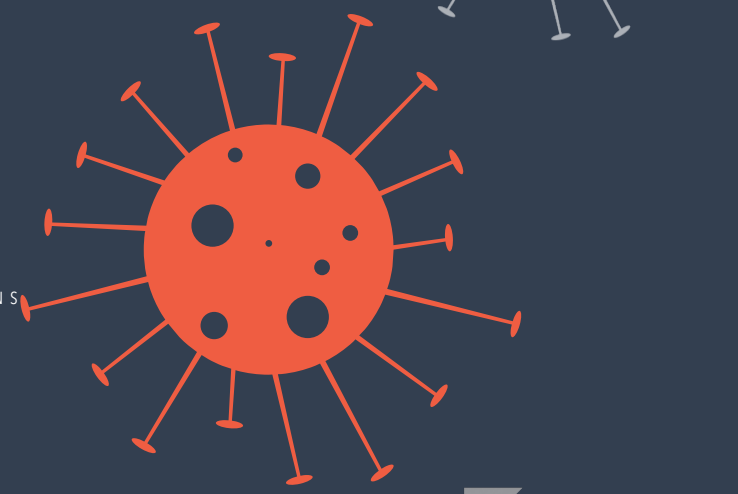


(C) Renato Miguel do Carmo, Inês Tavares e Ana Filipa Cândido (organizadores), 2020

Renato Miguel do Carmo, Inês Tavares e Ana Filipa Cândido (organizadores)

\section{Um Olhar Sociológico sobre a Crise Covid-19 em Livro}

Primeira edição: novembro de 2020

ISBN: 978-972-8048-58-7

DOI: $10.15847 / C I E S O D 2020$ covid19

Capa: Ana Filipa Cândido

Edição gráfica de texto e composição: Inês Tavares

Revisão de texto: Inês Tavares e Renato Miguel do Carmo

Reservados todos os direitos para a língua portuguesa,

de acordo com a legislação em vigor, por Observatório das Desigualdades

Observatório das Desigualdades, CIES-Iscte, Av. das Forças Armadas, 1649-026 Lisboa

E-mail: info@observatório-das-desigualdades.com

Site: http://observatorio-das-desigualdades.com

Como citar: Carmo, Renato Miguel do; Inês Tavares; e Ana Filipa Cândido (orgs.) (2020), Um Olhar Sociológico sobre a Crise Covid-19 em Livro, Lisboa, Observatório das Desigualdades, CIES-Iscte. Consultar aqui: https://www.observatorio-dasdesigualdades.com/2020/11/29/umolharsociologicosobreacovid19emlivro/ 
Índice

INTRODUÇÃO

Ana Filipa Cândido, Inês Tavares e Renato Miguel do Carmo

DESIGUALDADES SOCIAIS E PANDEMIA

António Firmino da Costa

A SAÚDE E A COVID-19 EM PORTUGAL: UMA REFLEXÃO A MEIO CAMINHO ANDADO

Tiago Correia

A EDUCAÇÃO E A COVID-19: DESIGUALDADES, EXPERIÊNCIAS E IMPACTOS DE UMA PANDEMIA NÃO ANUNCIADA

Susana da Cruz Martins

O IMPACTO DA CRISE DA COVID-19 NAS DESIGUALDADES SOCIOLINGUÍSTICAS E ÉTNICO-RACIAIS

Ana Raquel Matias

ELOGIO DA CO-PRESENÇA NO ENSINO SUPERIOR: BREVES NOTAS

João Teixeira Lopes

O SECTOR ARTÍSTICO E CULTURAL, IMPACTOS E DESAFIOS DA CRISE PROVOCADA PELA COVID-19

José Soares Neves

HABITAÇÃO, PANDEMIA, CRISE

Ana Drago

PANDEMIA E AMBIENTE: IMPACTOS E CONSEQUÊNCIAS

Luísa Schmidt

COVID-19 E DESIGUALDADES DE GÉNERO: UMA PERSPETIVA

INTERSECCIONAL SOBRE OS EFEITOS DA PANDEMIA

Sofia Aboim 
O IMPACTO DA COVID-19 NA VIOLÊNCIA NAS RELAÇÕES DE INTIMIDADE: PISTAS PARA REFLEXÃO

Madalena Duarte

ENVELHECIMENTO NAS COMUNIDADES NO PÓS-COVID-19

A DESIGUALDADE ECONÓMICA E A CRISE EXISTENCIAL DO PAÍS

Frederico Cantante

A POBREZA E A PANDEMIA EM PORTUGAL, UM ENSAIO

Fernando Diogo

A PANDEMIA NA ACADEMIA: FAZER, E TRANSFORMAR, O TRABALHO CIENTÍFICO EM TEMPOS DE COVID-19

Maria do Mar Pereira

HABITAR O TEMPO: UMA POLÍTICA DE RECONSTRUÇÃO DO SIMBÓLICO

Renato Miguel do Carmo

BALANÇO E PERSPETIVAS DE FUTURO: O IMPACTO DA COVID-19 E A (RE)PRODUÇÃO DAS DESIGUALDADES SOCIAIS

Inês Tavares e Ana Filipa Cândido 


\section{INTRODUÇÃO}

\section{Ana Filipa Cândido, Inês Tavares e Renato Miguel do Carmo}

Investigadores do Observatório das Desigualdades, Iscte - Instituto Universitário de Lisboa, CIES-Iscte

O processo de formação deste livro nasce a partir de uma rubrica de vídeos com nome homónimo a este livro ${ }^{1}$ promovida pelo Observatório das Desigualdades, publicados com uma média bissemanal entre 7 de abril e 8 de junho de 2020. Tanto pelo interesse e projeção que a rubrica alcançou, como pelo potencial acrescido que os contributos em vídeo poderiam ter no registo escrito, convidámos os autores a escrever um capítulo sobre o tema abordado inicialmente. Os textos reunidos neste livro apresentam uma reflexão diferente $e$, de certa maneira, mais aprofundada, decorrente de um maior distanciamento em relação ao início da pandemia ou das características intrínsecas que este novo formato suscita.

Neste momento as sociedades atravessam uma crise profunda e singular provocada pela pandemia Covid-19. O período de confinamento representou um esforço monumental por parte dos indivíduos e respetivas famílias. $O$ isolamento não só quebrou a regularidade dos laços e das ligações sociais em copresença e proximidade física, como está a gerar um conjunto de processos disruptivos decorrentes do confinamento e do prolongamento de um conjunto de restrições sociais e cívicas no período posterior. Não há sociedade decente que se baseie no desligamento e na interrupção das relações sociais ou no aprofundamento drástico das vulnerabilidades socioeconómicas. O que estamos a viver representa uma anormalidade que não pode (não deve) transformar-se no novo normal. Se isso

\footnotetext{
${ }^{1}$ A rubrica encontra-se no youtube e pode ser consultada aqui
} 
acontecer é a própria noção de sociedade que pode estar em causa. De maneira a melhor compreendermos os impactos e as consequências desta crise - que é simultaneamente sanitária e socioeconómica - nas desigualdades sociais, desafiámos vário/as sociólogo/as a refletir sobre esta realidade a partir do olhar especializado. Os seus contributos, primeiro em forma de entrevista e agora em registo escrito, podem, assim, ajudar a dar algum sentido a toda esta incerteza e instabilidade que partilhamos coletivamente.

É neste sentido que o presente livro nasce, apresentando uma reflexão continuada sobre i) as primeiras pistas para analisar a atual situação; ii) a relevância das políticas públicas tomadas desde o início do surto e que políticas serão necessárias implementar; iii) que mudanças existirão nas diferentes esferas em análise; iv) que impacto e consequências esta pandemia tem e terá nas desigualdades sociais.

Torna-se assim relevante analisar $\bigcirc$ acentuar e intensificar das desigualdades sociais já percetíveis nas atuais sociedades, de modo a enfrentá-las de forma mais esclarecida no momento presente e no desenho de políticas públicas futuras. Neste quadro, compreende-se ainda que a sistemática produção científica tem sido de elevada importância na elaboração de respostas adequadas.

Gostaríamos de agradecer os contributos dos autores dos capítulos deste livro - Alda Botelho Azevedo, Ana Drago, Ana Raquel Matias, António Firmino da Costa, Fernando Diogo, Frederico Cantante, João Teixeira Lopes, José Soares Neves, Luísa Schmidt, Madalena Duarte, Maria do Mar Pereira, Sofia Aboim, Susana da Cruz Martins, Tiago Correia - que o tornaram bastante interessante de um ponto de vista sociológico acerca da análise das mudanças suscitadas pelo impacto da pandemia. ${ }^{2}$

Convidamos os leitores a ler os capítulos que se seguem, consubstanciando-se em reflexões sociológicas acerca das consequências desta pandemia nas desigualdades sociais. No final de

\footnotetext{
2 Bem como a Cristina Roldão, Manuel Carvalho da Silva e Rui Pena Pires pela participação nos vídeos da rubrica.
} 
cada capítulo foi inserido o vídeo correspondente à entrevista realizada no âmbito da rubrica.

Cada texto foi escrito ao abrigo do novo acordo ortográfico ou da antiga grafia, consoante decisão do autor. 


\section{CAPÍTULO 1}

\section{DESIGUALDADES SOCIAIS E PANDEMIA}

\section{António Firmino da Costa}

Sociólogo, CIES-Iscte, Iscte - Instituto Universitário de Lisboa

Quando no início do ano de 2020 a pandemia Covid-19 se disseminou no planeta, encontrou a sociedade humana mundial com um panorama de desigualdades sociais muito acentuadas. São desigualdades sociais múltiplas: económicas, educativas, de género, étnico-raciais; desigualdades no trabalho, nas liberdades, nos direitos, de cidadania, e outras. Além de múltiplas, essas desigualdades interligam-se entre si, de formas complexas, por vezes paradoxais, e produzem várias injustiças sociais e diversos tipos de discriminações (Costa, 2012). No conjunto, não são congruentes com padrões de civilização aceitáveis nos tempos atuais.

Conhecemos já bastante acerca dessas desigualdades sociais contemporâneas: a) desigualdades dentro dos países; b) desigualdades entre os países; c) desigualdades globais (Milanovic, 2016). Porém, só a partir da crise financeira de 2008, e das políticas de austeridade que the seguiram, com o enorme agravamento de problemas económicos, sociais e políticos daí decorrentes - só a partir daí começou a criar-se na esfera pública mundial uma perceção alargada de que, afinal, as desigualdades sociais no mundo atual são muito elevadas e que, em algumas dimensões decisivas, têm estado a agravar-se, de forma rápida e intensa.

É o caso das desigualdades de rendimentos, e, ainda mais, o caso das desigualdades de riqueza. Há cerca de quatro décadas que estas desigualdades de rendimentos e de riqueza têm vindo a acentuar-se na generalidade dos países, afunilando de forma desproporcionada os rendimentos e a riqueza num topo exíguo de hiper-ricos e hiperpoderosos (Piketty, 2014). 
Além das desigualdades de rendimentos e riqueza, estão igualmente a aumentar outras desigualdades no mundo atual. No entanto, também é verdade que outras desigualdades têm vindo a diminuir.

Por exemplo, o forte crescimento económico da China ao longo das últimas décadas conduziu a uma certa redução das desigualdades de rendimento médio da população entre a China e os países ocidentais (desigualdade entre países). Esta desigualdade entre países contribuiu, pois, para alguma redução das desigualdades no mundo como um todo (desigualdades globais). Porém, ao mesmo tempo, as desigualdades internas de rendimento da população da China passaram a aumentar significativamente (desigualdades dentro do país). Neste aspeto, de sentido contrário ao do anterior, as desigualdades internas deste país têm contribuído para o aumento das desigualdades de rendimentos do conjunto da população mundial (desigualdades globais).

Outro exemplo: as desigualdades educativas a nível global evidenciam também tendências ambivalentes. Por um lado, o alargamento dos sistemas educativos em grande parte do mundo tem reduzido as desigualdades de educação - as quais, ainda há meio século, estabeleciam um fosso enorme entre uma fração ínfima da sociedade com escolaridade de nível médio ou superior e a grande maioria da população que tinha apenas escolaridade elementar ou mesmo nenhuma. No último meio século, a situação alterou-se bastante a este respeito, como é sabido, reduzindo-se significativamente as desigualdades educativas. A entrada forte da população feminina na escola e os resultados educativos obtidos por ela é componente decisiva desta diminuição das desigualdades de educação.

Por outro lado, no entanto, desta nova situação surgiram também novas dinâmicas educativas inigualitárias. Um caso ilustrativo são as novas exclusões sociais educativas - daqueles que, por razões variadas, "vão ficando para trás", de fora dos novos padrões de escolaridade geral (Ávila, 2008). Outro caso ilustrativo é a nova clivagem meritocrática, que se vai estabelecendo entre os segmentos sociais com graus educativos superiores e os outros segmentos sociais, com 
vantagens e oportunidades muito desiguais, muito contrastantes - nas atividades profissionais, nas garantias de emprego, na capacidade de acompanhar as transformações tecnológicas, nos padrões culturais, nas redes de interconhecimento, na valorização do status, no reconhecimento social (Todd, 2017; Piketty, 2019).

Por exemplo, nos EUA, esta nova clivagem meritocrática soma-se com outra clivagem, entre os 1\% com concentração híper-acentuada de riqueza e poder face à aos outros $99 \%$ da população em geral. A confluência dessas duas desigualdades tornou-se explosiva nos EUA: no plano político, no plano sociocultural, no plano ambiental, no plano das relações internacionais, no plano da saúde pública (Case e Deaton, 2020) - e, agora, na situação dramática ali atingida na nova pandemia.

Quando a atual pandemia começou, a situação das desigualdades sociais no mundo caracterizava-se dessa maneira, retratada aqui em traços breves. Perante este panorama de desigualdades pré-existente, que impactos trouxe a pandemia Covid-19 nas desigualdades sociais contemporâneas?

Para já, no imediato, as evidências apontam, infelizmente, para o agravamento das desigualdades sociais no mundo e, na maior parte dos casos, em cada país. Primeira constatação: os mais desfavorecidos e vulneráveis estão a ficar ainda mais desfavorecidos e mais vulneráveis. Não se encontram praticamente exemplos de sentido contrário.

Na América Latina, na Ásia e em África - com grande parte das populações de rendimentos muito baixos, níveis reduzidos de escolaridade, atividade profissional informal ou com pouco enquadramento legal, condições de habitação precárias, sistemas de proteção social muito limitados e sistemas de saúde também muito limitados - aí, as situações de desigualdade têm vindo a agravar-se em muitas paragens, e, em muitas outras, estão em risco iminente.

As notícias mediáticas têm vindo a mostrar casos de grande vulnerabilidade e por vezes de grande dramatismo - por exemplo na Índia ou no Brasil. Porém, em muitas outras situações do mundo mais 
desfavorecido, nem sequer há praticamente notícias sobre elas. Pouco se fala do que lá se passa.

Nos países de maior desenvolvimento humano, em que Portugal se inclui, os impactos da pandemia Covid-19 no agravamento das desigualdades sociais têm estado também a verificar-se de maneira muito evidente e muito preocupante. Em diversas categorias sociais verificam-se situações de desigualdade acrescida e outras são atingidas por novas situações de desigualdade.

Desde logo, a categoria social dos trabalhadores de baixas remunerações e baixas qualificações. Muitos deles, com situações contratuais precárias ou mesmo na economia informal, eram à partida os mais mal situados na escala das desigualdades sociais, e estão agora a ser dos mais atingidos, quer pelos impactos diretos da crise pandémica, em termos de propagação da infeção, quer por impactos económicos que decorreram das respostas imediatas de contenção à pandemia, respostas indispensáveis do ponto de vista da saúde pública, mas com consequências económicas muito negativas, e que provavelmente se irão prolongar bastante.

São trabalhadores manuais e de serviços - operários industriais, trabalhadores dos transportes, da construção civil, da manutenção urbana, dos serviços pessoais - em geral com baixas remunerações, muitas vezes com situações de emprego precárias. Parte deles, com frequência os mais vulneráveis, são imigrantes, de grupos étnicos minoritários e pessoas alvo de estigmatização racista.

Na crise pandémica, e perante as suas consequências económicas e sociais, eles têm vindo a ser atingidos pelo agravamento das desigualdades. Aliás, de forma paradoxal: muitos deles são afetados fortemente por desemprego, subemprego, trabalho temporário, precariedade, risco de pobreza; e muitos deles prosseguem atividades que asseguram o funcionamento de estruturas, abastecimentos e cuidados de base - sem recurso ao teletrabalho, por razões inerentes a essas atividades. Tem sido usada, a respeito deles, a categoria de "trabalhadores essenciais", e eles têm sido dos mais expostos à infeção 
e à doença, tendo ao mesmo tempo baixas remunerações e baixas garantias contratuais no emprego.

Outra categoria social, os jovens adultos. São também eles dos mais afetados pelos impactos da pandemia, em termos de agravamento das desigualdades sociais. Antes da pandemia já era assim, mas agora as circunstâncias deles agravaram-se: dificuldades agravadas quanto ao emprego, quanto aos rendimentos, quanto ao prosseguimento de estudos superiores, quanto à autonomia pessoal. Em todo o mundo, são os jovens adultos que mais são alvo de desemprego, subemprego e precariedade laboral. Alguns ficaram sem rendimentos, muitas vezes colocados em situação muito difícil, ainda mais quando têm crianças nos seus agregados familiares.

Outra categoria social, os trabalhadores independentes. Foram também dos mais afetados pelo agravamento das desigualdades. Com o confinamento de pessoas e atividades, muitos ficaram sem atividade profissional e sem rendimentos de qualquer origem. Parte deles ficou colocada em situação de "pobreza instantânea".

Outra categoria social, os idosos. Têm sido também dos mais diretamente atingidos pela doença, pela sua maior vulnerabilidade à doença e pela sua maior vulnerabilidade às suas consequências mais gravosas. Porém, não só pelos riscos de saúde acrescidos, mas também pelas condições de existência social de muitos deles, quer devido a situações económicas de baixos rendimentos, quer devido a situações de laço social fragilizado, envolvendo dependência e/ou isolamento.

Outra categoria social, as crianças e jovens em idade escolar. Têm tido dificuldades em prosseguir quer as aprendizagens escolares, quer a socialização interpares, ambas fundamentais nos percursos sociais de crescimento. Estão em desigualdade educativa face às gerações anteriores e o afastamento físico e relacional das escolas alarga ainda mais as desigualdades entre eles - consoante os recursos educativos e económicos desiguais das respetivas famílias. As desigualdades de oportunidades futuras entre eles cavaram-se ainda mais.

E ainda outra categoria social, as mulheres, em especial as que trabalham em atividades de baixas qualificações e baixos rendimentos - 
também particularmente afetadas pela crise pandémica, em termos de agravamento de desigualdades sociais: quer pela suspensão ou encerramento de atividades económicas em que estão em maioria, por exemplo na hotelaria, restauração e serviços pessoais; quer pelo prosseguimento de atividades profissionais de esforço e risco agravado, sem recurso a teletrabalho, nomeadamente em serviços de saúde, lares de idosos, apoios domésticos, entre outros; e, ainda, pelo trabalho familiar ainda mais sobrecarregado nas situações de confinamento.

Para além deste balanço rápido de situações de desigualdade agravadas, pela pandemia e pelas suas consequências imediatas, podem já colocar-se questões de fundo para o futuro próximo. Há vários tópicos relevantes a este respeito, evidentemente. Mas gostaria de assinalar aqui apenas três, com implicações para a redução das desigualdades sociais no mundo atual - e também em Portugal. São três questões que nos interpelam para o futuro próximo: as desigualdades e o Estado social; as desigualdades e a transformação digital; as desigualdades e a ciência.

\section{Desigualdades e Estado social}

É sabido que os sistemas públicos de saúde, de educação e de proteção social têm sido fundamentais na contenção de desigualdades sociais ainda maiores. Apesar disso, nas últimas décadas, têm sido objeto de políticas de restrição ou mesmo tentativas de quase aniquilação.

No entanto, como seria o impacto social da pandemia em Portugal se não houvesse um Serviço Nacional de Saúde, de carácter basicamente universal, em que todas as pessoas afetadas pudessem ser tratadas da infeção, independentemente dos seus recursos económicos e da sua condição social? Como seria se não houvesse um sistema público de proteção social, se não houvesse pensões de reforma e de velhice, subsídios de desemprego e doença, e vários outros instrumentos de proteção social? Como seria se não houvesse sistema 
público de educação, com as soluções - parciais e provisórias encontradas no imediato da pandemia, e, sobretudo, com a manutenção, após desconfinamento, do enquadramento da grande maioria da população escolar no ensino público básico, secundário e superior?

Todos estes sistemas públicos do Estado social têm muitas lacunas e deficiências. Em certos períodos das décadas anteriores foram alvo de restrições e amputações. A própria ideia de Estado social, e dos seus sistemas públicos universais ou quase universais, foi alvo de tentativas de descredibilização.

Porém, esta gravíssima crise de saúde pública, e a crise económica e social a ela associada, demonstraram à evidência que a instituição do Estado social é indispensável para uma existência civilizada em sociedade no mundo atual. E, em particular, é fundamental para a contenção das desigualdades sociais em agravamento, e, desejavelmente, para as reduzir.

Em todo o caso, para que o Estado social desempenhe as suas funções e contribua decisivamente para a redução das desigualdades sociais, há duas prioridades que se tornaram salientes com a crise atual: o reforço dos sistemas públicos do Estado social e a acentuação do seu carácter universal.

\section{Desigualdades e transformação digital}

Com a crise de saúde pública da pandemia, o processo de transformação digital da sociedade teve um impulso enorme. Boa parte das soluções imediatas encontradas perante a crise pandémica tem envolvido instrumentos digitais.

Nas universidades, de maneira praticamente instantânea, o ensino tornou-se - provisoriamente - ensino à distância, com apoio em plataformas digitais. Vastos sectores económicos e administrativos foram rapidamente reorganizados com recurso maciço ao teletrabalho. O comércio eletrónico aumentou significativamente. Nas relações de família, amizade e sociabilidade, as comunicações eletrónicas 
multiplicaram-se e intensificaram-se. Tem surgido uma variedade de iniciativas comunicacionais, criativas, lúdicas e de experimentação nos estilos de vida. Na saúde, cresce rapidamente a utilização de novas tecnologias digitais por médicos e outros profissionais da saúde - e, com a pandemia Covid-19, surgiram as aplicações controversas de monitorização da infeção e da doença. Estão também a surgir, cada vez mais, instrumentos de base digital para a monitorização da mobilidade das pessoas e na monitorização de vários dos seus atos quotidianos.

E é aqui, justamente, que as questões se complicam, nomeadamente quanto às desigualdades sociais. Com efeito, tornamse cada vez mais evidentes as ambivalências da transformação digital. Estes dispositivos digitais, e a sua utilização generalizada, trazem sem dúvida enormes potencialidades, para diversos domínios. Mas trazem também enormes ameaças para os modos de existência humana em sociedade, nomeadamente de novos agravamentos e novos tipos de desigualdades sociais (Harari, 2018). Não se trata apenas de um vago horizonte futuro. É algo que está já bem presente e que agora a resposta à pandemia recolocou num novo patamar.

Veja-se, por exemplo, a nova concentração de dados. A par da reconhecida concentração de riqueza no mundo, extremamente desigual, constituiu-se agora uma nova concentração de dados, em meia dúzia de mega-empresas digitais e em alguns estados hiperpoderosos.

É uma assimetria gritante, com múltiplas implicações inigualitárias muito preocupantes. Já gerou algumas respostas institucionais, a mais conhecida das quais é a recente Regulamentação Geral de Proteção de Dados, da União Europeia, que tem méritos, mas que é também muito limitada face à magnitude do problema. Uma das suas maiores lacunas é, precisamente, a de não contemplar respostas a algumas das desigualdades sociais mais preocupantes implicadas na nova concentração de dados.

Outro exemplo é a impregnação dos algoritmos por preconceitos e critérios discriminatórios - nuns casos por inadvertência, noutros casos intencionalmente. Os critérios discriminatórios pré-existentes em 
sociedade, quando inscritos em algoritmos, tornam-se automatizados e multiplicados, reproduzindo e acentuando as desigualdades sociais. Além disso, na conceção de alguns algoritmos podem ser introduzidos novos critérios discriminatórios, desenhados especificamente para conduzir a determinadas configurações socialmente inigualitárias.

É certo que também seria possível construir algoritmos desenhados especificamente com orientação contrária, isto é, no sentido de garantir direitos de cidadania, evitar enviesamentos discriminatórios e conduzir a efeitos sociais de maior equidade. Há alguns exemplos interessantes neste sentido (Colclough, 2020). Porém, pelo menos para já, esta última possibilidade está largamente por se concretizar.

Outro exemplo são os sistemas de crédito social, implementados na China - em que as pessoas são monitorizadas nas suas atividades diárias por meios digitais: onde se localizam, quando se deslocam, quem contactam, quando e onde fazem compras, que atividades fazem ou não fazem, sendo-lhes atribuídos "pontos" positivos e "pontos" negativos e, em consequência, sendo-lhe ajustado em permanência o ranking da sua reputação pessoal, perante as autoridades e perante outras pessoas - e em consequência, também, o seu acesso, ou não, a recursos, empregos, casas, escolas, viagens, e tudo o mais (Kostka, 2019).

Em suma, uma estratificação social gerida por meios digitais, dirigida por hierarquias político-administrativas, com efeitos socialmente inigualitários generalizados.

Estes exemplos (a concentração de dados digitais, a impregnação dos algoritmos por critérios discriminatórios, os sistemas de crédito social), ilustram o que tem sido designado como a sociedade de vigilância (Zuboff, 2019): uma possível consequência distópica da transformação digital, conducente a desigualdades sociais cada vez mais acentuadas e cada vez mais presentes, de forma intersticial, em toda a organização social e em toda a existência humana em sociedade.

Acontece que - como sempre aconteceu, noutras transformações tecnológicas - as chamadas novas tecnologias disruptivas podem ser 
desenhadas e aplicadas de várias maneiras e com consequências sociais alternativas.

Tudo está a acontecer rapidamente e a crise pandémica é também um momento de encruzilhadas. As tecnologias digitais nomeadamente as envolvidas nas respostas à crise sanitária, económica e social - estão a ser tecnicamente desenhadas e socialmente utilizadas com agravamento das desigualdades e com surgimento de novas desigualdades? Ou poderão ser tecnicamente desenhadas e socialmente utilizadas para a redução das desigualdades sociais, incorporando nos seus protocolos e aplicações um conjunto de critérios de respeito pelas liberdades democráticas, pelos direitos humanos e pelo sentido de justiça social?

\section{Desigualdades e ciência}

As possibilidades de enfrentar no imediato a pandemia Covid-19 e as expectativas de obtenção de soluções para a doença no médio prazo têm sido, em grande parte, depositadas pela opinião pública na ciência e nos cientistas, desde logo nos médicos, epidemiologistas, biólogos e outros especialistas da saúde.

Mais ainda. Em poucos meses, cientistas, universidades, centros de investigação, laboratórios, ensaios clínicos, projetos de pesquisa, conhecimentos científicos, necessidades de mais conhecimento científico, controvérsias científicas - tudo isto passou a fazer parte da conversação pública. Em certa medida, nas atuais circunstâncias, a cultura científica dos cidadãos parece ter dado um passo mais avançado (Entradas, 2020).

É certo que a esfera pública é atravessada também por fake-news, teorias obscurantistas, opiniões anti-científicas e mensagens de desinformação, veiculadas por "bolhas" nas redes sociais e por aparelhos de propaganda comandados por políticos autoritários como Trump ou Bolsonaro, Putin ou Xi Jinping. Nessa constelação cultural perversa, o desrespeito pelos factos e o desrespeito pelos direitos aparecem em conjunto. À luz do dia ou em contrabando, germinam 
nessa constelação cultural, em afinidade eletiva, o desrespeito pelo conhecimento científico e o desrespeito pelas liberdades democráticas.

No entanto, os inquéritos feitos em vários países do mundo, já em plena crise de saúde pública, mostram que a maioria das pessoas está a atribuir nova credibilidade e confiança à ciência e aos cientistas. Num contexto em que as políticas públicas e as ações quotidianas dos cidadãos sejam mais informadas pelo conhecimento científico, serão também maiores as possibilidades das desigualdades sociais serem conhecidas melhor e enfrentadas de maneira mais esclarecida.

Neste sentido, os contributos das ciências sociais ganham relevância específica na situação atual - quer em si mesmas, quer em colaboração interdisciplinar com outras ciências, nomeadamente com as ciências da vida e da saúde e com as ciências e tecnologias digitais.

Perante o cortejo de entorses à justiça social e ameaças à existência humana democraticamente organizada que a intensificação das desigualdades está a gerar, mais ainda numa situação extraordinária de crises encadeadas - pandémica, económica e social -, os contributos das ciências sociais tornam-se indispensáveis, quer para o melhor conhecimento das novas circunstâncias inigualitárias, quer para uma ação mais informada na contenção e desagravamento das desigualdades sociais nas novas circunstâncias.

Referências bibliográficas

Ávila, Patrícia (2008), A Literacia dos Adultos, Lisboa, Celta.

Case, Anne; e Angus Deaton (2020), Deaths of Despair and the Future of Capitalism, Princeton, Princeton University Press.

Colclough, Christina (2020), "Workers' rights: negotiating and co-governing digital systems at work", Social Europe.

Costa, António Firmino (2012), Desigualdades Sociais Contemporâneas, Lisboa, Mundos Sociais. 
Entradas, Marta (2020), Preocupados mas Confiantes, na Ciência e nas Decisões Políticas (Estudo de opinião pública sobre a comunicação da Covid-19. Resultados preliminares), Lisboa, CIES-Iscte.

Harari, Yuval Noah (2018), 21 Lições para o Século XXI, Amadora, Elsinore.

Kostka, Genia (2019), "China's social credit systems and public opinion", New Media \& Society, 21(7), pp. 1565-1593.

Milanovic, Branko (2016), Global Inequality, Cambridge (Mass.), The Belknap Press of Harvard University Press.

Piketty, Thomas (2019), Capital and Ideology, Cambridge (Mass.), The Belknap Press of Harvard University Press.

Piketty, Thomas (2014), Capital in the Twenty-First Century, Cambridge (Mass.), The Belknap Press of Harvard University Press.

Todd, Emmanuel (2017), Où en sommes-nous?, Paris, Seuil.

Zuboff, Shoshana (2019), The Age of Surveillance Capitalism, London, Profile Books. 
Entrevista realizada a António Firmino da Costa no âmbito da rubrica "Um olhar sociológico sobre a crise Covid-19", publicada a 8 de junho de 2020.

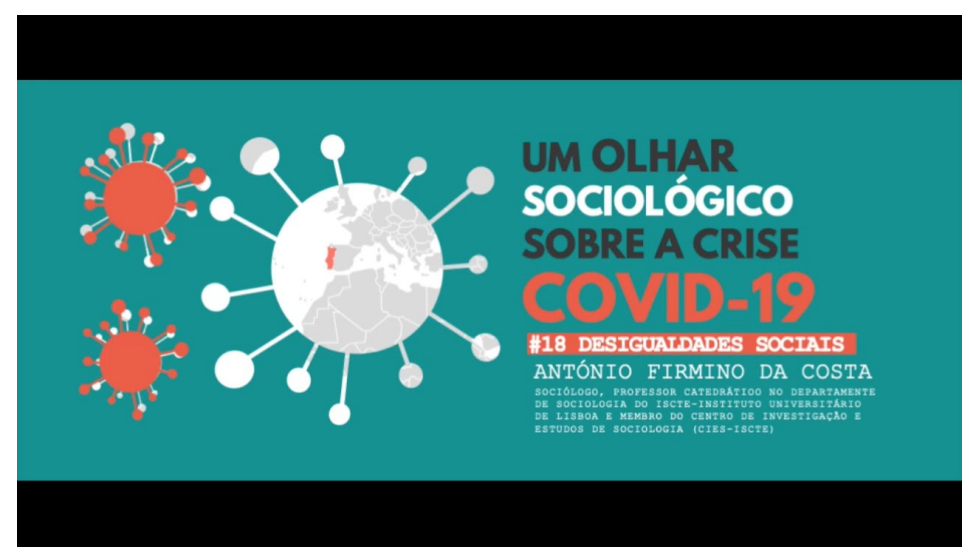




\section{CAPÍTULO 2}

A SAÚDE E A COVID-19 EM PORTUGAL: UMA REFLEXÃO A MEIO CAMINHO ANDADO

\section{Tiago Correia}

Sociólogo, Professor de saúde internacional, UHMT - Universidade Nova de Lisboa

Introdução

Os últimos meses foram vertiginosos numa realidade desconhecida. Isso motiva a urgência da procura de novos factos e números atualizados, mas que nem sempre informam ou ajudam a compreender o que estamos a viver e o que podemos esperar.

Nos primeiros dias de abril de 2020 fui desafiado pelo Observatório das Desigualdades para pensar sobre o que estávamos a viver no contexto da saúde e projetar o futuro em relação à pandemia e às desigualdades sociais (Correia, 2020a). Vivíamos a primeira fase do Estado de Emergência e as dúvidas sobrepunham-se às respostas.

Cinco meses após essa reflexão convido a um olhar retrospetivo. Este texto foi escrito nos primeiros dias de setembro e procurou perceber como as tendências de abril evoluíram e em que medida essa reflexão ajuda a compreender o que ainda temos pela frente, mesmo que o futuro não seja de projeção fácil.

É certo que uma epidemia causada por uma infeção respiratória era mais do que esperada, mas o facto de se tratar de um novo agente infecioso e da rapidez com que atingiu a totalidade do planeta torna tudo muito mais difícil de compreender, gerir e prever. Em termos cronológicos, se se confirmar a produção de uma ou mais vacinas das que se encontram na terceira fase de ensaios clínicos, então estaremos a meio caminho: 6 meses volvidos, 6 meses pela frente. Mas o que temos pela frente não será fácil porque o passado não se vai repetir: temos mais respostas e sabemos como agir, mas o perfil 
epidemiológico parece estar a alterar (a contaminação está a ocorrer mais em pessoas jovens e daí o aumento de casos assintomáticos) e teremos a circunstância da circulação de outros vírus respiratórios habituais no outono e inverno.

A estrutura deste ensaio tem por base as perguntas que me foram colocadas em abril. Recordarei os pontos gerais das minhas respostas, a que acrescento uma interpretação crítica sobre o que se verificou e o que não se verificou. Termino com uma reflexão sobre o futuro imediato.

\section{Pistas para analisar a situação pandémica}

Disse que a análise da pandemia deveria basear-se em três pistas: controlar as cadeias de transmissão, minimizar a exposição ao mercado e garantir a gestão comunitária da doença. Mantenho a convicção que estas são as principais pistas para uma boa análise da situação.

Em relação ao controlo das cadeias de transmissão, parece hoje claro que o objetivo é evitar que um número significativo de pessoas precise de cuidados de saúde. Sabe-se que quanto mais a procura cresce, menor é a qualidade dos cuidados prestados porque o risco de erros involuntários aumenta e as opções terapêuticas disponíveis não são suficientes. Foi isso a que assistimos em Itália, Espanha ou EUA. Foi isso também que vimos ser a preocupação da China, quando em janeiro dá início à construção de hospitais que ficaram concluídos e operacionais em poucas semanas.

Estar atento ao controlo das cadeias de transmissão tem duas outras implicações. Uma diz respeito aos objetivos epidemiológicos e políticos, a outra aos indicadores que devem ser analisados na evolução epidemiológica. Referi noutro texto (Correia, 2020b) que os vários países têm seguido quatro objetivos distintos: erradicar as cadeias de transmissão (Nova Zelândia, Islândia ou Tailândia), gerir as cadeias de transmissão (generalidade dos países europeus), ignorar as cadeias de transmissão (EUA, Brasil e Reino Unido numa fase inicial) e incapacidade de gerir as cadeias de transmissão (generalidade dos países de baixo 
rendimento). Referi também que não só não tem havido uma mensagem clara sobre qual o objetivo a seguir em Portugal, como em Portugal a única opção é apostar na gestão das cadeias de transmissão. Isto significa que é expectável o surgimento de novas infeções, que tentar erradicar as cadeias de transmissão é virtualmente impossível devido a fatores sociodemográficos, epidemiológicos, políticos e económicos do país, e que as consequências dessa tentativa seriam tão ou mais prejudiciais do que a próprio SARS-CoV-2. Refiro-me a aspetos tão diversos como a redução do rendimento das famílias, ao aumento das desigualdades na aprendizagem escolar e ao agravamento das condições de saúde.

A ausência desta mensagem provoca medo na população e o desgaste dos decisores técnicos e políticos perante novos surtos. Este medo e desgaste tem aumentado ao longo dos meses.

Em traços gerais, os fatores que considero tornarem impossível a erradicação das cadeias de transmissão em Portugal são: a estrutura etária envelhecida da população e o quadro de vulnerabilidade da população idosa (entenda-se a conjugação de baixa escolaridade e rendimento, as condições da institucionalização em lares, a ausência de laços familiares e as más condições de habitabilidade - ver Cabral et al., 2013); a elevada incidência de doenças crónicas e de comorbilidades (Correia, Carapinheiro e Raposo, 2018); os imperativos decorrentes da livre circulação de pessoas no âmbito da União Europeia e do Espaço Schengen, mas também os imperativos de salvaguarda do bem-estar individual e de combate às desigualdades sociais inscritos no Estado de Direito Democrático que, tanto quanto possível, devem limitar opções políticas mais repressivas; por fim, a estrutura económica e produtiva do país, incluindo as características do emprego (a forte componente de atividades dos sectores primário e secundário, a preponderância de micro e pequenas empresas, o número de trabalhadores independentes, a precariedade laboral e os baixos salários).

foco na gestão das cadeias de transmissão e não na sua erradicação faz com que não haja um número mágico de novos casos que nos indique se estamos bem ou mal. Desde logo, porque não há 
termos de comparação exatos. Chamo a atenção para os limites das comparações internacionais: sabemos o quanto os países não adotam os mesmos critérios estatísticos nem a mesma política de rastreio e testagem. Sabemos também que as comparações não são estáticas porque têm em linha de conta a evolução comparativa entre países.

Daqui decorre a segunda implicação: que indicadores devem ser analisados na evolução epidemiológica? Como se percebe, não dou relevância exclusiva ao número de novos casos, mas sim à conjugação com a evolução percentual, olhando simultaneamente para valores diários e semanais para identificar tendências mais e menos imediatas. A este respeito, as variações diárias em Portugal têm estado abaixo de $1 \%$, indicador que considero positivo na gestão da transmissão. Outros indicadores que tenho em conta numa doença para a qual ainda não há cura nem a chamada imunidade de grupo e que continuamos a saber que na maioria dos casos é assintomática ou provoca sintomas ligeiros são o número diário de internamentos, incluindo em unidades de cuidados intensivos, e de óbitos. Estes indicadores têm estado muito estáveis com tendência a melhorar (salvo raros episódios), o que reforça a minha leitura de que o país tem conseguido gerir as cadeias de transmissão.

Em suma, o que importa estar atento é o crescimento repentino de casos, pois sabe-se que em certo momento esse aumento terá reflexo nos internamentos e, consequentemente, nos óbitos. Como referi, considero que a persistência diária de novos casos é expectável e não é em si um problema, porque o único objetivo epidemiológico e político possível de seguir em Portugal, sem comprometer em demasia a vida social e económica, é a gestão dos contágios.

A segunda pista que referi foi o grau de exposição ao mercado, quer das famílias quer dos países. Quanto às famílias procurava chamar a atenção para dois aspetos: a prestação e o financiamento privado. Sabendo-se que parte não menosprezável da atividade em saúde em Portugal depende do sector privado (em concreto, os meios complementares de diagnóstico e terapêutica, a saúde oral, mas também as consultas médicas e a atividade cirúrgica) (Correia, 2019), 
quis alertar para a possibilidade de deixar de haver prestação privada de cuidados de saúde (em que o exemplo paradigmático foi a entrada do SAMS em regime de layoff), simultaneamente com a menor capacidade das famílias em financiar esse acesso. Tínhamos os primeiros sinais de aumento do desemprego e diminuição do rendimento. Estava por se perceber as consequências para os resultados em saúde e para o possível aumento da procura no Serviço Nacional de Saúde (SNS).

Passado este tempo percebe-se que o problema teve contornos sistémicos não diretamente a ver com o mercado. É verdade que a atividade privada foi reduzida a níveis cujas implicações para a saúde e para o aumento da procura no SNS não foram inteiramente conhecidas. Mas é óbvio que a parte fundamental do problema está relacionado com a suspensão da atividade programada não-Covid-19 em hospitais e cuidados de saúde primários do SNS. Desenvolvo esta questão mais à frente.

Quanto aos países, procurava chamar a atenção para desequilíbrios bem conhecidos no acesso a tecnologias médicas. Referia-me à velha dicotomia norte/sul, que descreve condições desiguais entre países de alto e baixo rendimento para disponibilizarem cuidados de saúde às populações. A compra do stock mundial de Remdesivir pela Administração Trump é o exemplo mais claro deste argumento.

Restam poucas dúvidas que a geografia, nacional e internacional, deve ser entendida como uma construção política marcada pela injustiça na disponibilidade de meios e na exploração de recursos e pela desigual atenção a problemas e procura de soluções (Soja, 2010). A questão mais óbvia tem a ver com a disponibilização de vacinas. Mas não devem ser ignoradas questões mais subtis como avaliar a conformidade dos ensaios clínicos com os princípios éticos consagrados ou a adequação das respostas políticas de confinamento,

\footnotetext{
1 Medicamento antiviral destinado a outros vírus (Ébola ou Marburg) e que tem sido ensaiado a título experimental em doentes com Covid-19, não havendo ainda indicações claras sobre os seus resultados.
} 
higienização, distanciamento social e utilização de meios de proteção individual nos diferentes países. Isto, tanto do ponto de vista económico (sobretudo em contextos de pobreza e de outras vulnerabilidades sociais) como do ponto de vista epidemiológico (na gestão de outras doenças infeciosas e crónicas).

A terceira pista que referi foi a gestão comunitária da doença. Sabendo-se que parte significativa das pessoas infetadas não requer cuidados médicos em instalações de saúde, mas sabendo-se que este vírus é de elevada transmissibilidade, a devida atenção é necessária para evitar o aumento repentino de casos e essa atenção deve residir na comunidade. É na comunidade que primeiramente se intervém para reduzir fatores de risco (por exemplo, na gestão dos transportes públicos ou na utilização de espaços fechados). É na comunidade que se compreende a maior ou menor dificuldade em conter as cadeias de transmissão (por exemplo, sabe-se que a conjugação de elevada concentração populacional, agregados familiares numerosos, precariedade laboral e baixos rendimentos dificultam a contenção das cadeias de transmissão). É na comunidade que estão as infraestruturas para apoiar as pessoas em isolamento ou quarentena. É na comunidade que se encontram as redes de apoio que contribuem para repor alguma normalidade social e psíquica em tempos disruptivos. É na comunidade que se adotam os comportamentos individuais preventivos que podem diminuir o ritmo de transmissão do vírus. Em suma, é na comunidade que encontramos as principais estruturas, recursos e comportamentos de promoção da saúde e prevenção da doença.

Tornou-se inequívoco ao longo destes meses, e a situação vivida na região de Lisboa e Vale do Tejo serve como exemplo, que a gestão comunitária da doença tende a ser tanto mais efetiva quanto mais rápida for a testagem, a produção de diagnóstico e a capacidade de mobilizar recursos para manter as pessoas em isolamento. Entre o Instituto Nacional de Saúde Dr. Ricardo Jorge, o Laboratório Militar, o Instituto Nacional de Investigação Agrária e Veterinária, laboratórios privados, laboratórios de hospitais públicos e de universidades, contamse cerca de 90 instalações que realizam testes diários (Fronteira e 
Augusto, 2020). Isto é determinante num país em que o objetivo epidemiológico e político só pode passar pela gestão das cadeias de transmissão.

Também é verdade que a gestão das cadeias de transmissão na comunidade deixaram a nu problemas de intersectorialidade horizontal e vertical das políticas e dos organismos públicos e privados. A persistência de surtos na região de Lisboa e Vale do Tejo em junho e julho e aquilo que se tem vindo a saber sobre os óbitos no lar de Reguengos de Monsaraz ilustram o quanto mais trabalho é preciso no envolvimento dos vários atores centrais e locais e na fiscalização da qualidade dos serviços prestados pelo Estado a grupos vulneráveis. Fica a dúvida sobre se as devidas lições foram retiradas destes casos perante a possibilidade de aumento de casos de Covid-19 durante o outono e inverno. É certo que os problemas têm uma natureza estrutural que requerem alterações estruturais (por exemplo, no reforço do internamento na Rede de Cuidados Continuados Integrados, dos serviços domiciliários e dos meios financeiros e recursos humanos para a área da saúde pública). Ainda assim, medidas imediatas têm de estar pensadas para evitar as dificuldades sentidas na gestão dos contágios em Lisboa e na situação vivida nos lares. Nos últimos dias foi anunciada a constituição de equipas de emergência para atuar em lares em situação de contágio (Lusa, 2020). A satisfação com que a medida foi recebida contrasta com o atraso com que foi tomada. Era óbvio que uma parte importante das Estruturas Residenciais Para Idosos (EPRI) não tinha capacidade de cumprir os planos de contingência.

Adequação das políticas públicas à situação pandémica

Após alguma inconsistência inicial na antecipação da importação de casos e na monitorização das pessoas que tinham estado em mobilidade, o decretar do Estado de Emergência em março trouxe maior afinação das respostas políticas e, mais importante, a preocupação de planeamento das fases subsequentes. Contudo, o arrastar da situação pandémica e das suas ramificações pela economia, 
trabalho, solidariedade social, finanças, educação, ciência, cultura, serviços públicos, infraestruturas e administração interna, torna difícil a avaliação nominal de todas as medidas entretanto adotadas. Todos temos memória de decisões mais e menos consensuais e todos temos noção de que tem havido momentos de maior e menor aproveitamento político.

Neste ensaio apenas consigo fazer uma avaliação genérica da adequação das políticas públicas e, em termos globais, considero que a ação dos decisores políticos (órgãos de soberania, autoridades de saúde, municípios), dos principais partidos políticos e dos meios de comunicação social contribuiu para a estabilidade epidemiológica e política necessária num momento de emergência sem paralelo. Encaro a discordância política e a vigilância, tanto jornalística como por parte da sociedade civil, como mecanismos úteis para a riqueza do debate público e como contrapesos que melhoram a tomada de decisão em momentos vertiginosos. Claro que retiro de tudo isto o aproveitamento político e corporativo, a demagogia e a sobreposição de interesses parciais face ao interesse coletivo.

Ainda assim, não posso deixar de notar que o início de setembro tem sido marcado pelo aumento da crispação política, da partidarização de decisões técnicas e da divergência editorial no relato jornalístico da atualidade pandémica. Estes factos deixam antever um ambiente de fragmentação política e social na gestão da Covid-19 durante os meses do outono e inverno. As consequências negativas não tardarão a manifestar-se.

Por certo podemos referir medidas que se tenham revelado ineficazes ou contraproducentes (por exemplo, a sobrecarga de funções dos médicos de medicina geral e familiar no acompanhamento de doentes Covid-19, de doentes não-Covid-19 e de utentes institucionalizados em ERPIs que tem levado à demora nas respostas nos cuidados de saúde primários e ao desgaste dos profissionais) (Schreck, 2020). Por certo podemos criticar a oscilação nalgumas orientações das autoridades que dificultaram a gestão do dia-a-dia e 
contribuíram para alguma desinformação (por exemplo, a definição de regras para a utilização das máscaras) (Malta e Coelho, 2020).

Mas sublinho que o que vamos conhecendo de outros países mostra que tal ineficácia e oscilações não são problemas exclusivos de Portugal, logo têm menos a ver com a suposta má qualidade das decisões e mais com a complexidade de fenómenos novos para os quais as políticas vão sendo testadas, por vezes, na tentativa e erro. Sublinho ainda que parte dessa ineficácia e oscilações decorreu da própria Organização Mundial de Saúde (OMS). O papel da OMS na gestão desta pandemia é um tema que deve ser tratado à parte, ainda que seja óbvio que a OMS tem sido um bode expiatório fácil no debate nacional. A OMS está no epicentro de geografias injustas, desiguais e contraditórias, comunica para o mundo inteiro e tem de produzir informações concretas para países em situações não comparáveis entre si. Não subscrevo que não se proceda a uma avaliação crítica da ação da OMS. O que digo é que para que isso seja feito é necessário compreender os meandros desta organização e que o seu funcionamento assenta em tensões, direi, irresolúveis. Algumas pistas para essa compreensão podem ser lidas em português em Almeida e Campos (2020).

Mesmo que faça uma avaliação global positiva da adequação das políticas não deixo de olhar para dois aspetos que podem afetar o resultado das respostas políticas. O primeiro é a fiscalização das medidas implementadas. Por muito bom que seja o desenho das políticas, compete às autoridades a sua fiscalização e sabemos o quanto isso nem sempre tem funcionado, pelo menos sem o auxílio dos holofotes mediáticos. O funcionamento dos lares serve novamente como exemplo. O segundo aspeto diz respeito à colagem partidária de organismos técnicos e das decisões que têm sido tomadas. Quanto aos organismos técnicos refiro-me à Direção-Geral da Saúde (DGS), que vem sendo arrastada para a realpolitik. Sendo cada vez mais óbvio o desgaste da instituição e da Diretora-Geral, os atores políticos devem proteger este organismo sob pena do agravamento do seu descrédito numa altura de incerteza sobre as medidas que terão de contar com a 
adesão da população. Quanto às decisões tomadas, a esmagadora maioria - senão todas - têm respaldo em orientações da OMS, na literatura científica e estão em linha com as opções seguidas nos países com os quais Portugal se compara. Claro que a especificidade de cada país obriga a medidas nem sempre coincidentes. A persistência de surtos na região de Lisboa em junho e julho são exemplo disso. Daí ter afirmado que não vejo outra solução para Portugal senão a gestão dos contágios, assumindo como inevitável a persistência diária de casos e de um número residual de óbitos, mesmo que noutros países os resultados epidemiológicos, sobretudo durante os meses de verão, tenham sido melhores.

Tentar separar as medidas técnicas dos partidos que as propõem não visa proteger nem atacar qualquer ator político. Procura, isso sim, contribuir para uma leitura justa sobre o quanto daquilo que se tem vivido em Portugal podia ou tinha forma de ser gerido de outra forma. Volto a chamar a atenção para as debilidades sociodemográficas, epidemiológicas e económicas do país que ajudam a contextualizar porque faço uma avaliação global positiva das políticas públicas.

\section{Mudanças no sistema de saúde}

Afirmei que passada a pandemia não antevia mudanças na estrutura e no funcionamento do sistema de saúde em Portugal. Ou seja, que apesar da situação pandémica ter exposto as fragilidades dos sistemas de saúde, pelo menos no caso português, tudo voltará a uma relativa normalidade.

Mantenho essa leitura, mesmo que hoje tenhamos uma noção mais clara dos problemas que o SNS terá de gerir no futuro imediato. Refirome à suspensão da atividade programada não urgente (consultas, cirurgias e meios complementares de diagnóstico e terapêutica) (Maia, 2020), cujas consequências ainda não são bem conhecidas além do aumento da mortalidade "não-Covid-19" (Nogueira, 2020). Percebe-se que tem havido descompensação no acompanhamento de doenças crónicas, na produção de diagnósticos e no agravamento da saúde 
mental. Parece óbvio que precisamos de atingir um ponto de equilíbrio. É tão grave um "óbito Covid-19" como um "óbito não-Covid-19" e é tão grave falhar o rastreio da Covid-19 como falhar o rastreio de outras doenças infeciosas e crónicas.

Em traços gerais, atribuo a resistência a tais mudanças à falta de consenso sobre o papel e o estatuto do SNS no sistema de saúde. O SNS não foi na sua origem, nem tem sido ao longo das décadas, uma construção pacífica e a consequência disso são políticas vai-e-vem ou a escusa de debates que se tornaram verdadeiros tabus, mesmo que esses debates sejam fundamentais para assegurar 0 respeito pelos princípios constitucionais de universalidade, generalidade e tendencial gratuitidade dos cuidados. Estes tabus são a necessidade de repensar a arquitetura do financiamento do sistema de saúde, a sucessiva incapacidade de alterar a organização do trabalho entre os vários grupos profissionais e a sucessiva indefinição do papel que a prestação privada deve assumir perante o SNS. Portanto, situações como aquela que vimos de conflito entre a Ordem dos Médicos e o governo a partir do caso do lar de Reguengos de Monsaraz, quanto a mim, têm muito mais significado político, senão mesmo partidário, do que uma discordância corporativa neutral.

Em resumo, os principais motivos de mudança que considero existirem no sistema de saúde não dizem respeito à Covid-19, mas às indefinições e bloqueios que o sistema de saúde tem vindo a sofrer no campo político. O tempo passa sem que o sistema de saúde esteja a ser adaptado à realidade epidemiológica, social e demográfica do país.

\section{Políticas após a pandemia}

À margem das mudanças estruturais que identifiquei, a gestão da Covid-19 tem demonstrado o quanto os sistemas de saúde precisam de estar devidamente equipados a nível da promoção da saúde, prevenção da doença e respostas para o tratamento, cura e gestão da doença. Isto traduz-se na necessidade de investimento em meios técnicos, tecnológicos e humanos nos cuidados de saúde primários, onde se 
inclui a saúde pública, cuidados hospitalares e cuidados paliativos e continuados. É devido à necessidade desta amplitude de respostas que precisamos de debater os tabus que sinalizei.

A situação que vivemos tem mostrado que qualquer sistema de saúde tem pontos fortes e fracos. No caso português, o ponto forte tem sido a produção de diagnóstico, o que envolve a disponibilidade de testes, de equipas de colheita, de uma rede laboratorial público-privada que tem estado acima de qualquer crítica, de normas para o seguimento dos casos suspeitos, dos que aguardam confirmação e dos casos confirmados, e de meios tecnológicos (por exemplo, as falhas na linha de Saúde24 durante os meses de março e abril foram resolvidas com relativa prontidão e eficácia). O ponto fraco tem sido o acompanhamento dos casos confirmados e a manutenção do funcionamento do SNS para os casos "não-Covid-19". Estas situações têm muito a ver com a política de recursos humanos no SNS, em concreto a falta de profissionais, a má distribuição de profissionais por especialidades, regiões e valências de cuidados (primários, secundários e continuados) e desequilíbrios na organização e divisão do trabalho entre grupos profissionais (Correia et al., 2018). A contratação de mais de 5.500 profissionais para o SNS desde março é uma demonstração deste argumento.

Mas mesmo que estas lacunas sejam corrigidas, importa perceber que a capacidade dos sistemas de saúde para lidar com a magnitude de contágios que tivemos com o SARS-CoV-2 será sempre limitada. O sistema de saúde representa apenas uma das componentes para a gestão de uma epidemia e se nada for feito noutros domínios, o resultado será certamente o colapso das infraestruturas e dos profissionais de saúde. Foi isso que vimos acontecer em países tão diferentes como a China, Itália, Espanha, EUA, Brasil, México, África do Sul ou Índia. É neste sentido que se deve intervir na intersectorialidade entre áreas de governação (intersectorialidade horizontal) e na intersectorialidade entre níveis de decisão (vertical). Referi o quanto é preciso fazer mais e melhor a este respeito em Portugal. 
Além da aposta intersectorial, o primeiro foco de ação para controlar uma pandemia é a nível internacional. Quanto mais cedo se intervir, mais eficazes serão os resultados. Como tenho dito: as epidemias não se gerem, evitam-se através da capacidade de serem antecipadas. No contexto de progressiva facilidade de circulação de pessoas à escala planetária é imperativo o reforço da cooperação internacional para o rastreio, identificação e reporte de doenças infeciosas. $\bigcirc$ que a Covid-19 deixou claro foi que as relações geopolíticas internacionais permaneceram num grau de tensão e hierarquia desfasado face aos avanços na mobilidade internacional de pessoas e mercadorias. A eficácia da saúde pública de um país deixou de ser matéria exclusiva desse país e a seriedade do reporte por parte das autoridades nacionais perante instâncias internacionais é tanto um assunto de ética como de direito internacional.

A esta questão também não são alheios temas como a ecologia e as relações de comércio internacional. Porque não pode ser assumido como um acaso o facto de epidemias por infeções respiratórias causadas por contágio animal terem origem em países asiáticos e a resposta não é apenas as lacunas das condições sanitárias dos mercados locais. Para isso em muito contribuem as lógicas de organização da produção agropecuária e o "contágio" de modos e estilos de vida. Não pode passar despercebido que o aumento do consumo de proteína animal nos países asiáticos nos últimos 50 anos seguiu padrões idênticos àqueles verificados nos países ocidentais no começo do século $X X$ e que se relacionam com a industrialização, a globalização de gostos e tendências, o comércio internacional de bens alimentares frescos/vivos e a redução dos custos de produção (FAO, 2002). Há cada vez mais sinais e menos dúvidas de que a pressão simultânea dos países asiáticos e ocidentais sobre os recursos naturais é incomportável para o planeta e que mudanças terão de acontecer nas expectativas de consumo e estilos de vida. 
Impacto da pandemia nas desigualdades em saúde

A influência de fatores sociais no contágio de doenças e no estado de saúde das pessoas é bem conhecida. A este respeito, a Covid-19 não trouxe nada de novo. Sabemos que as características do emprego potenciam o risco de exposição e de contágio. Por exemplo, há atividades que simplesmente não podem ser exercidas à distância e que a segurança dos trabalhadores depende tanto dos seus comportamentos individuais, como da qualidade das medidas preventivas asseguradas pelas entidades empregadoras. A precariedade laboral e os baixos salários também dificultam a gestão dos contágios devido ao medo de despedimento ou de não renovação de contratos e aos casos de multi-trabalho em que as pessoas acumulam atividades, muitas vezes por via informal, para compor o seu rendimento.

Sabemos também aquilo que se chama a cumulatividade dos fatores de desigualdade social. Ou seja, que existem diversos atributos que produzem desigualdades sociais (por exemplo, a idade, o género, a escolaridade, a rede familiar, de amigos e de conhecidos, etc.) e que esses atributos se condicionam mutuamente. Pessoas com escolaridade mais baixa tendem a ter rendimentos mais baixos, atividades laborais de maior risco para a saúde, uma rede de apoio menos eficaz para auxílio em caso de necessidade, menor capacidade de compreender a informação e por aí fora. Em contraponto, pessoas com escolaridade mais alta tendem a ter rendimentos mais altos, atividades laborais de menor risco para a saúde, uma rede de apoio mais eficaz e maior capacidade de compreender a informação.

Nos meses de março e abril percebeu-se que as pessoas com menor rendimento foram as que mais perderam rendimento e que mais foram expostas ao vírus (Barómetro Covid-19, 2020). À luz da cumulatividade dos fatores de desigualdade social é de esperar que estas pessoas sejam também aquelas com piores condições de saúde, que mais precisam de se expor ao vírus (por exemplo, não podendo optar pelo trabalho à distância ou tendo que utilizar espaços públicos, incluindo os 
transportes) e que têm maior dificuldade para filtrar as boas e más informações sobre este vírus.

Nos meses mais recentes tem havido uma alteração do perfil sociodemográfico dos contágios. Ocorrem crescentemente em pessoas mais jovens. Neste momento é este facto que explica que o aumento de novos casos não esteja a levar ao aumento de internamentos e de óbitos. Por norma, o vírus é assintomático ou causa sintomas ligeiros à esmagadora maioria das pessoas que não têm outras doenças.

Mas esta alteração veio reacender um debate que tem na sua essência uma forma de desigualdade social. Refiro-me à desigualdade motivada pela idade. Assiste-se a um "cisma grisalho" em que os esforços de mitigação dos contágios são criticados porque a doença afeta pessoas já vulneráveis a outras doenças e que os efeitos económicos e laborais desses esforços são, por isso, desproporcionais face aos ganhos. Cabe-me dizer o seguinte: qualquer doença tem associada significados, onde se inclui medos e expectativas. Duvido que o argumento da desproporcionalidade das medidas de mitigação fosse usado caso o SARS-CoV-2 afetasse as crianças, tal como aconteceu com a gripe espanhola entre 1918 e 1920. Nessa circunstância, estou certo de que não haveria o ímpeto em usar o argumento económico. Ora, limitar o direito à vida por qualquer motivo, incluindo motivos económicos, não só é inconstitucional como representa um retrocesso civilizacional que envergonha. $\bigcirc$ processo civilizacional tem sido construído com base em diversas formas de solidariedade, entre as quais a etária, a de género, de nacionalidade, de grau de escolaridade, e a relativa à condição de saúde, etc..

Por si só este argumento justifica que se procurem as melhores soluções para conter as cadeias de transmissão e assim proteger os grupos vulneráveis, tal como fazemos (ou temos a obrigação de fazer) em relação a qualquer outra doença. Também é relativamente óbvio que essas soluções têm de ter um ponto de equilíbrio em relação aos efeitos perversos que causam. É isso que as autoridades políticas querem dizer quando afirmam que o país não aguenta um novo confinamento. 
Além deste argumento, o facto de se tratar de um novo vírus, e de ser o primeiro coronavírus a atingir a escala planetária, deve motivar todas as cautelas enquanto a ciência procura respostas concretas. Se ainda há dúvidas sobre os meios de transmissão do vírus, a duração dos anticorpos e se as consequências da Covid-19 são apenas respiratórias ou podem ser sistémicas, é imprudente desconsiderar a proteção da população.

\section{Pistas sobre o que nos espera}

Não tenho dúvida que medidas de mitigação são necessárias para gerir as cadeias de transmissão do SARS-CoV-2. Defendo esta posição devido à falta de conhecimento científico acerca do vírus e ao facto de em países tão diferentes assistirmos ao colapso dos sistemas de saúde e ao aumento de mortes evitáveis quando as medidas tardam. Por muito que no futuro se chegue à conclusão de que afinal o vírus não é tão prejudicial como inicialmente se suspeitou, a ação política de hoje não pode esperar por essas evidências e tem que avançar com base nas experiências passadas e no conhecimento disponível, por muito contraditório que esse conhecimento possa ser. Também por isso reforço a necessidade de as pessoas compreenderem as mudanças de posição e as dúvidas acerca de várias medidas. Isso decorre da falta de respostas científicas concretas e de ser necessário colocar numa balança os ganhos e as perdas quando se opta num sentido ou noutro sentido.

No início de setembro de 2020 os casos voltam a subir a nível mundial. Na Europa isto acontece ainda antes do outono e do regresso escolar. Não é clara a evolução dos casos nas próximas semanas, mas as condições teóricas deixam antever uma situação complicada de gerir: é necessário manter as pessoas em circulação ao mesmo tempo que essa circulação irá potenciar contágios de SARS-CoV-2 e de outros vírus respiratórios. Isto irá acontecer num ambiente político mais crispado e de maior desconfiança das pessoas. É importante que haja uma mensagem clara que por muito que façamos temos apenas condições de ir gerindo as transmissões, não erradicá-las. Nessa gestão é 
fundamental que as pessoas adotem os comportamentos preventivos atualmente conhecidos e que haja a disponibilidade de testes para testar os contactos de casos confirmados. Antevejo menor disponibilidade das pessoas para aceitarem manter-se em quarentena, pelo que a política de testagem é a única solução para permitir a manutenção da vida social e laboral.

Perante o surgimento constante de novos casos, as pessoas devem compreender a necessidade de adaptar os seus comportamentos a várias circunstâncias. O mesmo se aplica a empregadores e aos decisores políticos na definição das regras para o funcionamento das atividades comerciais e para a convivência social. Dentro do atual quadro preventivo, certas regas devem ser proporcionais à situação epidemiológica. Foi isso que aconteceu em diversas freguesias de Lisboa e concelhos limítrofes que se mantiveram no Estado de Calamidade.

O que não me parece adequado - nem acredito que tenha adesão das pessoas - é que as mesmas restrições sejam aplicadas independentemente da situação epidemiológica local e que as populações não tenham a informação sobre o que se passa nos locais onde vivem, trabalham e procuram atividades de lazer. Ou seja, os comportamentos e as regras da vida quotidiana devem ser definidos através de diferentes riscos epidemiológicos a nível local (o que pode corresponder a freguesias ou concelhos). É esta a abordagem seguida na Nova Zelândia. Estão definidos diferentes níveis de alerta e as medidas correspondentes em função das cadeias de transmissão ativas, do número de casos, do número de casos nas últimas 24 horas, do número de pessoas recuperadas e da origem e estado atual da transmissão. Uma reflexão da aplicação destes princípios em Portugal é dada por Sakellarides e Araújo (2020).

Até haver uma vacina ou a doença se tornar endémica, temos de ter noção que vamos viver momentos de maior e menor restrição da nossa normalidade. Para já, não identifico sinais que me levem a temer que esta situação ameace definitivamente direitos e garantias individuais. Vejo que o que temos pela frente é muito mais uma lógica de 
circunstâncias (já lhe chamei "ioiô") na qual em certos momentos teremos de decidir o que é verdadeiramente essencial e acessório na nossa vida quotidiana. Tal significa que certas vontades e comportamentos poderão não ter forma de ser concretizados num dado momento. Certamente encontraremos formas criativas de reinventarmos a procura de bem-estar e de prazer com a convicção de que a velha normalidade poderá não tardar muito a regressar.

\section{Referências bibliográficas}

Almeida, Célia; e Rodrigo Pires de Campos (2020), "Multilateralismo, ordem mundial e Covid-19: questões atuais e desafios futuros para a OMS", Saúde em Debate (ahead of print).

Barómetro Covid-19 (2020), Opinião Social: Pandemia aumenta fosso das desigualdades, Lisboa, Escola Nacional de Saúde Pública.

Cabral, Manuel Villaverde; Pedro Moura Ferreira; Pedro Alcântara da Silva; Paula Jerónimo; e Tatiana Marques (2013), Processos de envelhecimento em Portugal: usos do tempo, redes sociais e condições de vida, Lisboa, Fundação Francisco Manuel dos Santos.

Correia, Tiago (2020a), Um olhar sociológico sobre a crise Covid-19|\#1 Tiago Correia, Lisboa, Observatório das Desigualdades.

Correia, Tiago (2020b), "A gestão política da Covid-19 em Portugal: contributos analíticos para o debate internacional", Saúde em Debate, ahead of print.

Correia, Tiago (2019), "Saúde", em Ricardo Paes Mamede e Pedro Adão e Silva (coords.), Menos Reformas, Melhores Políticas, Lisboa, IPPS-IUL, pp. 12-16.

Correia, Tiago; Graça Carapinheiro; e Hélder Raposo (2018), "Desigualdades Sociais na Saúde: um olhar comparativo e compreensivo" em Renato Miguel do Carmo e outros (coord.), Desigualdades Sociais: Portugal e a Europa, Lisboa, Mundos Sociais, pp. 23-39.

Correia, Tiago; Gilles Dussault; Inês Gomes; Mário Augusto; Marta Temido; e Patrícia Nunes (2018), "Recursos humanos na saúde: o que se sabe e o que falta saber", em OPSS (coord.), Relatório Primavera 2018, Lisboa, OPSS, pp. 68-107. 
FAO (2002), Some Issues Associated with the Livestock Industries of the AsiaPacific Region, Tailandia, Food and Agriculture Organization of the United Nations, Regional Office for Asia and the Pacific.

Fronteira, Inês; e Gonçalo Figueiredo Augusto (2020), Portugal - Covid-19 Health System Response Monitor, Brussels, European Observatory on Health Systems and Policies.

Lusa (2020), "Covid-19: Brigadas com 400 profissionais vão apoiar lares afetados por surtos", Lusa (publicado online a 4 de setembro 2020).

Maia, Ana (2020), "Mais de 40\% dos doentes à espera de cirurgias fora do prazo aceitável", Público (publicado online a 17 agosto 2020).

Malta, João Carlos; e Miguel Coelho (2020), "Medina critica indefinição da DGS em relação ao uso das máscaras", Rádio Renascença (publicado online a 14 abril 2020).

Nogueira, Mariana Almeida (2020), "Três gráficos para perceber os picos da mortalidade este ano em Portugal", Visão (publicado online a 4 agosto 2020).

Sakellarides, Constantino, e Fernando Araújo (2020), "A Public Health Strategy for the COVID-19 Pandemic in Portugal: Learning from International Experience", Acta Médica Portuguesa, 33(7-8), pp. 456-458.

Schreck, Inês (2020), "Utentes desesperam para marcar consulta nos centros de saúde", Jornal de Notícias (publico online a 8 de julho 2020).

Soja, Edward (2010), Seeking Spatial Justice, Minnesota, University of Minnesota Press. 
Entrevista realizada a Tiago Correia no âmbito da rubrica "Um olhar sociológico sobre a crise Covid-19", publicada a 7 de abril de 2020.

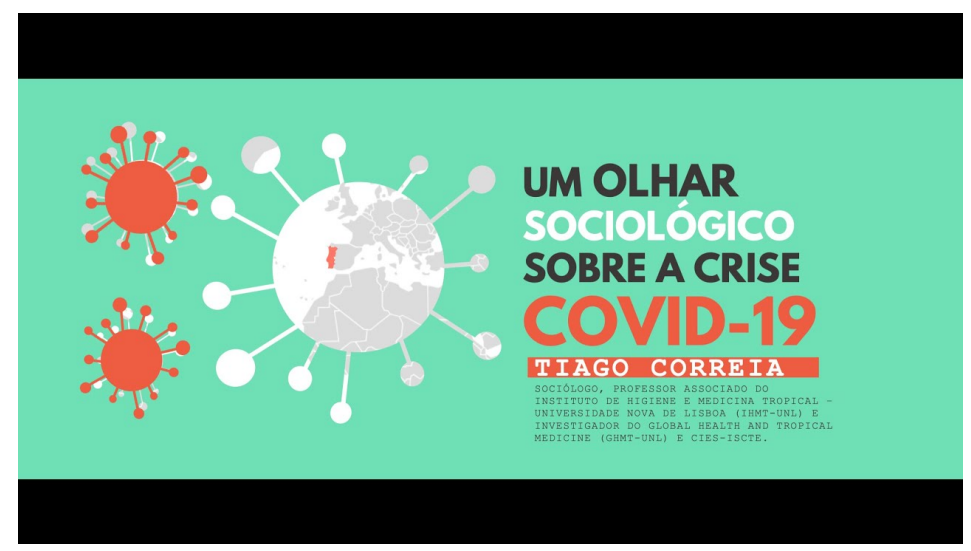




\section{CAPÍTULO 3}

A EDUCAÇÃO E A COVID-19: DESIGUALDADES, EXPERIÊNCIAS E IMPACTOS DE UMA PANDEMIA NÃO ANUNCIADA

\section{Susana da Cruz Martins}

Professora na Escola de Sociologia e Políticas Públicas (Iscte - Instituto Universitário de Lisboa), Investigadora do CIES-Iscte

\section{Introdução}

Se a pandemia provocada pela Covid-19 fosse um episódio passado da nossa história contemporânea, talvez o pudéssemos recordar com a distância necessária para analisar as suas consequências diretas e os mecanismos de mudança por ele acionados numa série de áreas e dimensões sociais da nossa vida coletiva. Neste caso iremos aproveitar o conhecimento já disponível sobre uma pandemia ainda em curso.

Uma dessas áreas, onde a pandemia teve e continua a ter impactos muito vincados, foi a educação e, mais propriamente, os sistemas educativos e as escolas, onde um dos mais evidentes e diretos foi o fecho das escolas. Este encerramento não foi, em si, um evento singular na nossa história. A gripe pneumónica, ou gripe espanhola como também é conhecida, talvez a mais mortífera de todos os tempos (Sobral e Lima, 2018), obrigou igualmente ao fecho de escolas e ao adiamento dos exames de acesso à universidade (Almeida, 2012). Algumas das anteriores pandemias já carregavam consigo os efeitos colaterais da globalização. Isto se neste largo recipiente conceptual pudermos incluir, por exemplo, os movimentos internacionais dos militares ao serviço da I Guerra Mundial. Eles, que entre outros fardos, transportaram consigo esse vírus da gripe pneumónica. No entanto, em 2020 tal encerramento não se traduziu na interrupção do ano letivo nem, pelos menos totalmente, das atividades letivas ou escolares, e tais condições permitem analisar esta experiência histórica, não só como repentina, mas como relativamente original. 
Tal originalidade é reforçada pela simultaneidade do encerramento das escolas, não só em Portugal, mas em quase todo o mundo (Nações Unidas, 2020).

Este capítulo procura analisar as primeiras manifestações desta pandemia nas escolas, apresentando algumas das semelhanças e diferenças entre sistemas educativos a partir desta experiência; identificar as medidas políticas adotadas para fazer face aos seus efeitos nas escolas; fazer o reconhecimento das suas consequências nas desigualdades, em particular nas desigualdades educativas; e sinalizar as possíveis transformações na educação e no sistema como parte das consequências do episódio pandémico.

Uma nota adicional de reforço da problemática prende-se com o equacionamento dos impactos e reações à pandemia, tendo a instituição escolar como a principal referência dessa análise, as suas funções e características num quadro organizacional e de governança específicos. Muitas das medidas tomadas, mesmo que necessárias do ponto de vista sanitário, são contrárias à própria essência institucional da escola e das suas funções primordiais. Certamente esta questão terá que estar sempre presente na própria análise das repercussões da pandemia nos sistemas educativos.

Pistas de análise e experiências internacionais

Os meses de março e abril de 2020 foram marcados pelo fecho total ou parcial das escolas um pouco por todo o mundo. No início desse mês de abril, cerca de $91 \%$ dos estudantes, em termos mundiais, foram afetados pelo encerramento, pelo menos em parte, das escolas, com efeitos relativamente generalizados em 193 países. ${ }^{1}$ Esta foi mesmo a consequência mais drástica e direta da pandemia nos sistemas educativos (Nações Unidas, 2020).

Esta medida inicial não foi de carácter educativo, teve apenas critérios de saúde para a sua concretização. A seguir somaram-se preocupações sociais e educativas para minimizar os efeitos imediatos, desde logo muito drásticos, nos sistemas educativos.

A impossibilidade de interação direta e presencial entre estudantes e professores interrompeu o processo de aprendizagem sem que uns e outros se

\footnotetext{
1 Isto de acordo com dados compilados pela UNESCO.
} 
pudessem preparar para esse facto. $\bigcirc$ que é conhecido em Portugal é que as escolas reagiram de forma muito diversificada ao restabelecimento do contacto com os seus estudantes. As iniciativas para o retomar da relação educativa e do processo de ensino-aprendizagem foram também pautadas por realidades muito diferenciadas. Tal variabilidade foi visível na concretização de um ensino à distância, nas suas lideranças (em muitas escolas teve um carácter atomizado, cada professor usava uma estratégia ou plataforma, noutras houve maior coordenação) e na sua capacidade comunicacional (nomeadamente, no contacto com alunos e famílias).

Em termos mundiais, o estabelecimento do ensino à distância teve formatos e dispositivos também muito distintos. A figura 1 é muito elucidativa a este respeito: a internet foi o meio privilegiado para o retomar do contacto entre professores e estudantes. Na Europa, e excetuando o pré-escolar, o uso da internet foi de $100 \%$ em todos os níveis de ensino. Realidade bem diferente em África, onde esta possibilidade foi, comparativamente, mais reduzida, ainda que presente em muitas das suas escolas (figura 1). De uma outra perspetiva, a utilização da internet reforçou-se sempre nos níveis de escolaridade mais avançados. A rádio só foi usada de forma relevante nos países africanos, mais propriamente na CITE$^{2}$ 1, por exemplo, em que mais de 2 terços dos seus países fizeram esta utilização. A televisão foi também um meio muito importante, nomeadamente em países africanos e asiáticos (rondando os 75\% nas CITES 2 e 3) e na Europa, embora tivessem prevalecido os formatos digitais, aquele meio serviu de dispositivo complementar ou de articulação com outros.

2 UNESCO, Classificação Internacional Tipo da Educação (CITE) 2011. 
Figura 1 - Instrumentos para o ensino à distância, por regiões mundiais e níveis de ensino (2020) (em intervalos de \%)
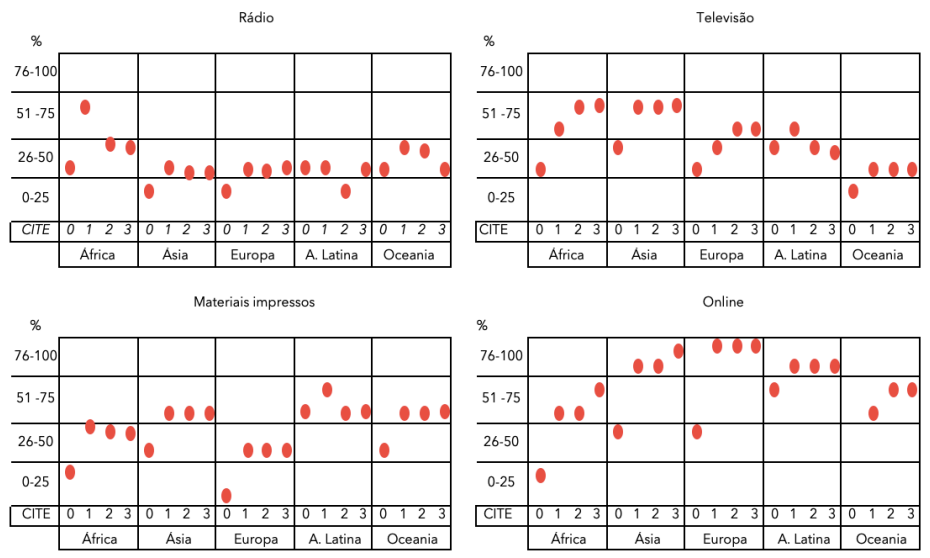

Fonte: adaptado de Nações Unidas (2020: 13).

A reação pronta para o ensino à distância dependeu de capacidades e recursos do próprio sistema, no que diz respeito às seguintes dimensões de atuação (UNESCO, 2020:2-3): a) resposta tecnológica (uso pronto de plataformas de aprendizagem digital, transmissões na televisão e rádio de conteúdos curriculares para todos. E, ainda, o acesso por parte das famílias a eletricidade, telefones, televisores, rádio, dispositivos digitais, internet e dados móveis, entre outros); b) acessibilidade a materiais de ensino e aprendizagem alinhados com os currículos nacionais (oferecidas através de plataformas online, programas de TV ou em casa em materiais impressos); c) apoio pedagógico e à aprendizagem em casa (prende-se, por exemplo, com a preparação dos professores para promover o ensino à distância e a disponibilidade e capacidade dos pais para promover a aprendizagem efetiva em casa); d) monitorar os processos de ensino à distância, acompanhar $\mathrm{o}$ acesso às aulas e o envolvimento nelas, avaliar os 
resultados da aprendizagem, e obter respostas imediatas de ensino à distância para atingir metas de longo prazo.

O relatório da UNESCO (2020), quando levanta as respostas acionadas durante o período de fecho das escolas, organizadas nas dimensões anteriormente expostas, dá conta também de problemas na execução dessas respostas. Por um lado, a dificuldade imediata em colocar à disposição aulas e conteúdos, devidamente enquadrados nos currículos e acessíveis através da internet ou na televisão ou na rádio. Por outro, os desafios colocados à transição de regimes de ensino, por parte dos professores, e as diferentes possibilidades de famílias de contextos culturais e experiências escolares diversos para acompanhar a aprendizagem em espaço doméstico. Por fim, a monitorização e acompanhamento das aprendizagens, tendo em conta o envolvimento dos estudantes, são, naquele contexto, difíceis de se realizarem, ainda para mais com a utilização de vias relativamente unidirecionais ou de pouca interação, como são por exemplo os programas de televisão (idem, 2020:2-3).

Em Portugal esta experiência foi vivida com as escolas encerradas, com o ensino presencial interrompido para todos os níveis de escolaridade, apenas com aulas presenciais para os $11^{\circ}$ e $12^{\circ}$ anos nas disciplinas cujos respetivos exames nacionais funcionassem como requisitos para o acesso ao ensino superior. Nos restantes anos de escolaridade mantiveram-se atividades de ensino e aprendizagem à distância, incluindo a avaliação aos alunos em moldes adaptados às circunstâncias; diversificando-se as estratégicas de comunicação (e-mail e outras plataformas de comunicação e-learning) e facultando conteúdos e instrumentos educativos adicionais, de fácil acesso, que as escolas e alunos puderam ter em conta (como os conteúdos em televisão, nomeadamente o \#EstudoEmCasa).

As soluções encontradas noutros países foram também o ensino à distância, sobretudo nas suas vias digitais ou online. Algumas ilustrações podem ser interessantes para um reconhecimento e análise das estratégias empreendidas. 
Em muitos países europeus a continuidade fez-se sobretudo a partir de plataformas digitais a partir do próprio Ministério da Educação, ou através de websites ou de plataformas e-learning (ou sistemas de gestão da aprendizagem, como também são conhecidas) (Banco Mundial, 2020). Nos casos da Áustria, Bulgária e República Checa, as mais variadas estratégias foram, como em Portugal, complementadas com conteúdos para televisão fornecidos por iniciativa também do Ministério da Educação. Ainda na Áustria e na Bulgária, o Ministério da Educação preparou um portal próprio, ou repositório de conteúdos, para apoio ao ensino à distância apenas para professores e/ou gestores escolares.

Na Croácia (cf. Banco Mundial, 2020), uma boa parte do ensino fezse através da televisão e é privilegiada a via telefónica para o contacto com os pais e, subsequentemente, com os filhos (estudantes).

A Finlândia (idem, 2020) foi um dos países que empenhou um conjunto de estratégias mais diversificadas e flexíveis, que pudemos conhecer a partir dos relatos largamente divulgados. Tal deve-se ao facto de, em circunstâncias relativamente normais ou regulares, a educação presencial já se conjugar com ambientes virtuais de aprendizagem. O seu sistema educativo acrescenta às plataformas genericamente utilizadas, jogos e simuladores nas suas estratégias educativas, tendo também já muito consolidada a comunicação entre escola e família. Apresenta, ainda, um conjunto de repositórios e bibliotecas de recursos educativos abertos divulgados e postos à disposição das escolas e seus atores, pela Agência Nacional Finlandesa para a Educação, em conjunto com o Ministério da Educação e Cultura.

Uma outra dimensão muito importante do processo de ensino aprendizagem e que mereceu muitas preocupações, nacionais e internacionais, foram os processos de avaliação e aferição das aprendizagens dos alunos. Aquilo que também foi sendo evidenciado, quer pela comunicação social quer por agências internacionais, como o Banco Mundial, ${ }^{3}$ e que de certa forma segmentou países na sua

\footnotetext{
3 Banco Mundial (2020).
} 
atuação, foi a continuidade ou a descontinuidade das avaliações de desempenho dos alunos (para o ano letivo de 2019/2020). Também a este propósito se pode fazer algumas ilustrações. Na Áustria, a avaliação do desempenho dos alunos foi interrompida até o recomeço das aulas presenciais. Por outro lado, em alguns países foram cancelados os exames, como na Suécia e em França, onde só será tida em conta a avaliação contínua. Em Itália está mesmo previsto um equivalente próximo às passagens administrativas. ${ }^{4}$ No Reino Unido, 50 governo cancelou de imediato, logo a seguir ao anúncio de fecho das escolas, os exames do ensino secundário e acesso ao ensino superior. $\bigcirc$ esquema final para a avaliação destes alunos resulta numa combinação da avaliação dos professores e o desempenho da escola e da turma em que se inserem. Sobre todas estas questões, os países organizados por governos regionais e/ou federais tiveram estratégias relativamente diferenciadas do ponto de vista interno em cada região - foi assim em Espanha e na Alemanha, onde a especificidade na atuação comportou uma forte componente de autonomia das suas regiões ou Länders.

Todas estas medidas foram tomadas tendo por referência um quadro de condições (nomeadamente digitais, incluindo diferentes conteúdos e instrumentos em diferentes avanços e graus de concretização e disponibilização entre países), de recursos qualificacionais e de competências digitais populacionais muito distintos, bem como possibilidades de autonomia diferenciada dos diferentes atores para a sua utilização e estratégia de ensino aprendizagem, resultando numa constelação de dimensões e variáveis que ainda não permite uma equação completa para a reflexão sobre as desigualdades observadas.

\footnotetext{
${ }^{4}$ Como veio nos vários meios de comunicação.

5 Tal arranjo vem documentando na imprensa e o debate levantado em Inglaterra sobre este processo também.
} 
Orientações políticas para um cenário imprevisível

Como já foi referido, dada a situação pandémica, o fecho das escolas tornou-se inevitável, aliás, uma medida quase universal, e a que teve mais efeitos no sistema educativo e na vida dos alunos. Tratou-se, pois, de uma medida de saúde pública e não tanto educativa.

Depois do fecho das escolas, um dos princípios implicados nas medidas políticas adotadas em Portugal foi o da continuidade do ano letivo. As soluções para que essa continuidade marcasse esta experiência é que foram muito diferenciadas e muito dependentes de desiguais recursos e infraestruturas para o efeito. A lógica que imperou nos discursos políticos foi a de criar no sistema a menor disrupção possível num cenário já de si de grande disrupção. Este princípio marcou também a lógica da avaliação do desempenho e dos resultados dos alunos que, com adaptações várias, foram continuadas. Tal não aconteceu, como regra, em todos os países. Veja-se em Itália, ${ }^{6}$ onde as avaliações foram interrompidas e os alunos transitaram de ano sem as classificações referentes ao ano letivo que se concluía em 2020. A incidência, com maior acuidade de medidas para atender aos anos terminais do secundário, pode querer dar conta de uma maior preocupação para que se conclua a escolaridade obrigatória e mais alunos possam transitar para o ensino superior.

Esta lógica da continuidade (possível) do ano letivo, mesmo que realizada à distância, vem plasmada no Decreto-Lei n. ${ }^{\circ}$ 14-G/2020 de 13 de abril, em que se estabelece as medidas excecionais e temporárias na área da educação, no âmbito da pandemia da doença Covid-19.

Muitas das medidas, tornadas conhecidas em abril de 2020, transportaram consigo o mérito de constituírem um relativo consenso entre os atores fundamentais e intervenientes. Em Portugal, o dia 09 de abril de 2020 trouxe o anúncio desse conjunto de medidas, pelo Primeiro-ministro, e vertidas para o mesmo Decreto-Lei, que orientam de forma mais concreta o modo como o sistema educativo deveria

\footnotetext{
${ }^{6}$ Difundido aqui.
} 
reagir a esta pandemia. Para o seu debate e definição foram convocadas as associações e organizações representantes dos dirigentes escolares, dos pais e encarregados de educação e dos professores.

Por outro lado, criaram-se modalidades flexíveis e diversificadas de continuação de comunicação entre escolas e os seus alunos e possibilidades que atendem aos vários contextos para difusão de conteúdos curriculares, onde o mais emblemático e com intenções de universalidade foi a transmissão de conteúdos pela televisão, a fazer lembrar o modelo da "telescola", com uma designação de imagem tecnológica reconvertida (\#EstudarEmCasa).

O confinamento colocou em evidência as dificuldades das escolas em entrarem no digital e adaptarem-se a esses contextos e recursos. Para as contrariar o governo lançou o programa - a Escola Digital onde se propõe um investimento de 400 milhões de euros. ${ }^{7}$

O retorno às aulas para um novo ano letivo foi marcado pela necessidade de a escola voltar ao seu modelo presencial e poder funcionar como tal - uma escola. No entanto, procurou-se a sustentabilidade do ensino presencial articulando com a segurança, traduzida em medidas de saúde e proteção de todos os atores em ambiente escolar. Tal obrigou ao reforço das lideranças e direções escolares em torno de instrumentos de planeamento e monitorização. Esta dupla vertente esteve também assente nesse duplo eixo, tanto da saúde e segurança (veja-se o Referencial Escolas - Controlo da Transmissão de COVID-19 em Contexto Escolar), ${ }^{8}$ como educativo, perspetivando-se estratégias de recuperação das aprendizagens (tendo

\footnotetext{
7 Este programa propõe-se dotar os alunos de computadores e reforçar a cobertura de rede, a aquisição de software, com dois tipos de programas: um para desenvolver a "capacitação digital dos docentes" e outro para a desmaterialização dos manuais escolares. Ver informação aqui.

${ }^{8}$ Que pode ser consultado aqui.
} 
por base o documento Orientações para a Recuperação e Consolidação das Aprendizagens, ${ }^{9}$ do Ministério da Educação).

Como nas várias áreas, as medidas para fazer face à crise e impactos da pandemia, por terem um carácter de urgência, tenderam a sobrepor-se a outros programas e políticas em curso, nomeadamente as respeitantes à promoção do sucesso escolar, à inclusão e à prevenção do abandono escolar. Pode, deste modo, haver o risco de as direções escolares se centrarem neste problema conjuntural, criando uma espécie de suspensão das políticas em meio escolar.

\section{A pandemia e o reforço das desigualdades}

O impacto cabal desta crise ainda não o conhecemos, mas um dos seus efeitos mais nefastos e mais difíceis de contrariar é o do agravamento das desigualdades.

Esta pandemia não encontrou sistemas educativos "livres de desigualdades". Estes contextos institucionais, na sua construção histórica, têm marcas constitutivas de desigualdade. Mesmo sabendo que os recursos que os sistemas educativos geram são essenciais no alargamento de oportunidades educativas e sociais, na promoção da igualdade e mobilidade social (Martins, 2017; Martins et al., 2016), são também muito evidentes as manifestações de desigualdades no seu interior (Green, Preston e Janmaat, 2006), onde Portugal é um referente observacional importante (cf. Seabra, 2009; Sebastião, 2009). Os dados do último PISA (OCDE, 2019) evidenciam, embora em graus diferenciados, desempenhos e competências de crianças e jovens distintos de acordo com as condições socioeconómicas dos pais. Para Portugal essa diferença é relativamente importante, embora encontremos maiores desigualdades entre os jovens do Luxemburgo, da Alemanha e da Hungria, ou muito mais reduzidas em países como Noruega ou Dinamarca.

\footnotetext{
9 Que pode ser consultado aqui.
} 
Em certa medida, a escola é um dos instrumentos mais eficazes para contrariar as desigualdades de partida, que assentam nos contextos e recursos familiares. Talvez tenha sido tal verificação que a pandemia mais abalou, aumentando os seus impactos no sistema educativo e a clarificação e aprofundamento das desigualdades de um modo tão crítico.

Em primeiro lugar, e talvez onde o conhecimento sociológico no domínio educativo tem dado contributos mais sólidos, a análise de como os contextos e recursos das famílias se traduzem nos percursos e desempenhos escolares dos filhos. Algumas das questões clássicas da sociologia da educação continuam, assim, a ter fundamento para a análise das desigualdades verificadas nos sistemas de educação e formação - vejam-se os estudos consagrados de Coleman e outros nos EUA (1966), ou de Bourdieu e Passeron em França (1964 e 1970) ou de Bernstein em Inglaterra (1975). Estes contributos, pioneiros e validados por muitos dos que lhes sucederam, permitem-nos dar conta que quando as aprendizagens ficam mais dependentes dos seus contextos familiares, como foi o caso do período de confinamento (entre março e junho de 2020), mais desiguais nas suas aquisições se tornam. A importância dos contextos e recursos das famílias no sucesso académico é habitualmente evidente, sobretudo no quadro de sociedades muito desiguais como a nossa, aspetos já muito antecipados por aqueles autores nos anos 60 e 70. Ora, um regime de ensino à distância, instalado para atender ao estado pandémico e até de emergência, tornou tais enunciados ainda mais evidentes. As escolas vinham a fazer bons progressos sobre o seu impacto na redução das desigualdades de aprendizagem e sucesso (Martins et al., 2018). Esta nova condição torna esse esforço ainda mais exigente e complexo. Estas desigualdades têm diferentes expressões quando consideramos o género ou a etnia, que tendem a marcar a longevidade e o sucesso dos percursos escolares (Mateus, 2017).

Em segundo lugar, numa outra dimensão do problema, identificamos as escolas e professores com realidades e capacidades instaladas muito desiguais para lidar com o regime de ensino à 
distância. No entanto, no acesso à internet sem fios (wireless Lan) nas escolas, por parte dos estudantes, Portugal apresenta dos valores mais altos da UE, sobretudo nos níveis de escolaridade mais elevados (CITE 2 e 3), mas com um dos piores rácios de aluno por computador (ou notebooks, tablets, etc.) (Comissão Europeia, 2019). Por outro lado, o que nos diz um relatório da rede Eurydice (2019), muito recente, é que em Portugal a formação digital e tecnológica adaptada à educação não existe de forma obrigatória na formação de professores. Os professores portugueses do ensino básico (CITE 1 e 2) são dos que têm menores níveis de confiança nas suas competências digitais (Comissão Europeia, 2019), nomeadamente na criação de conteúdos digitais e da literacia a lidar com a informação e dados. ${ }^{10}$ Contudo, é indesmentível o esforço levado a cabo por estes protagonistas em tempo pandémico, colocando em evidência um processo de adaptação repentina e de difícil equivalente na nossa história recente.

Em terceiro lugar, o acesso às tecnologias de informação por parte das famílias é muito diferenciado. Por exemplo, o acesso à banda larga nos agregados domésticos portugueses é dos mais desiguais, de acordo com as condições socioeconómicas das famílias, na Europa ( $\mathrm{Di}$ Pietro et al., 2020). Dados da Comissão Europeia (2019) dizem-nos, por exemplo, que em Portugal o acesso dos alunos é menor que a média desse conjunto de países, sublinhando desde logo desigualdades entre países. Mas dentro do nosso país também são de realçar as diferenças digitais entre a população. Isso é mais notado entre os mais jovens, ou seja, as crianças mais novas têm menos acesso do que as restantes. Ora, uma modalidade de ensino apoiada nesse tipo de acesso a computadores pessoais, internet e outros dispostitos digitais cria desigualdades entre famílias. Se não houver políticas de grande reforço de uso das tecnologias de comunicação nas famílias com jovens e crianças, o acesso à escola passa a ser o acesso à internet. Depois coloca problemas de desigualdade potencial em regiões com

10 Note-se que, em simultâneo, são dos mais envelhecidos da Europa (Rodrigues e outros, 2016), o que torna os processos de mudança e inovação um pouco mais exigentes. 
diferentes tipos de infraestruturas digitais e com diferentes níveis de acesso. Como se houvesse uma nova "interioridade", esta agora relativa ao acesso às redes digitais, que representa também um novo acesso à escola.

Em quarto lugar, Portugal nas últimas décadas teve uma das maiores reduções do abandono escolar na Europa, afastando-se das últimas posições, onde permanecem Espanha, Malta, Roménia ou até mesmo Itália. A interrupção de todas as atividades escolares presenciais (e não só as aulas), que impedem a presença na escola, reforçam, mais uma vez, a preocupação com o aumento do abandono escolar. A incidência de políticas de maior urgência para atender aos anos terminais do secundário, pode querer dar conta de uma maior preocupação para que se conclua a escolaridade obrigatória e que tantos ou mais alunos possam transitar para o ensino superior.

Notas finais: Na educação, o que mudará? E que políticas poderão ser equacionadas?

As respostas a estas duas interrogações carregam consigo ainda um lado muito especulativo. Para se conhecer melhor os efeitos desta pandemia, ainda em curso, devemos continuar a procurar conhecimento e a monitorizar as medidas que vão sendo tomadas para conter os seus piores impactos no sistema educativo.

Algumas tendências começam já a assentar no sistema e prendemse com matérias que, não sendo novas, a pandemia suscitou com maior acuidade e de modo mais premente.

O apelo e a mobilização das tecnologias de informação e comunicação na relação pedagógica e educativa vão, certamente, intensificar-se. Tal não pode obliterar o que tem sido o modelo escolar, baseado no presencial, e que favorece não só as aprendizagens e a sua maior equidade, como permite formas mais aprofundadas na socialização das novas gerações e na realização de sociabilidades por parte das crianças e jovens, tão essenciais para o seu crescimento. Atenda-se que o ensino à distância foi uma solução de recurso e só 
nessa condição deverá voltar a ser relevante ou dominante, ou seja, quando o presencial for uma impossibilidade. Talvez, em sede de autonomia escolar, se possam criar soluções mais diversificadas que permitam ter como essencial o regime presencial, mas combinando com exercícios realizados à distância ou feitos através de vias tecnológicas ou digitais.

A pandemia, e todo o período de confinamento, veio suscitar, não só em Portugal mas também noutros países, o debate sobre as avaliações de desempenho dos alunos, que já vinham a ser transformadas e repensadas pelas escolas, questionando a centralidade de instrumentos como testes ou exames, e que agora serão, certamente, alvo de uma nova discussão na sua relação com as aprendizagens e nas competências agora exigíveis.

As várias respostas nacionais não poderão ser feitas nos mesmos moldes nem vestir o mesmo fato. Devem precisamente atender aos seus contextos diferenciados e especificidades próprias. Também com a informação que já dispomos é possível descortinar alguns dos caminhos de atuação, como os enunciados a seguir, que permitem acudir ou fazer face ao pós-pandemia.

Uma das vias é reforçar recursos de escolas que demonstrem estratégias e capacidade para combater as desigualdades. Tal reforço deve prever, paralela e adicionalmente, o alargamento da ação social aos alunos cujas famílias ficaram com poucos rendimentos, nomeadamente a partir da crise gerada pela pandemia. Tais instrumentos, utilizados de forma associada, deverão constituir uma estratégia para evitar o abandono escolar.

Uma outra refere-se à qualificação dos professores. Neste momento, e segundo um relatório da Eurydice (2019) já aqui referido, somos dos poucos países da Europa em que a formação de professores não inclui competências digitais, nem de forma específica, nem de forma genérica ou transversal. Depois desta pandemia, tal tornou-se uma necessidade premente, permitindo também a aproximação aos contextos e universos informacionais e comunicacionais dos seus alunos e, se possível, nas escolas. A maior utilização de instrumentos de ensino à 
distância não se deve traduzir na desvalorização do espaço escolar e de um dos seus principais agentes, os professores. Pelo contrário, estes devem ser capacitados para continuarem a ser mediadores chave na relação educativa.

É muito importante o reforço de um plano tecnológico para as escolas e para o sistema educativo, que de certa forma foi interrompido ou muito contido a partir do início da década passada, curiosamente como resposta de contenção da crise financeira. É já conhecido o plano para o investimento de 400 milhões de euros, no quadro do programa Escola Digital. Tal resulta num enorme esforço (incluindo hardware e software), que não deve desconsiderar a importância de incluir as famílias, muito desiguais no seus recursos e competências digitais, a favor de uma estratégia de inclusão escolar.

A dimensão de turmas pode ser outro aspeto crítico. Num estudo recente, levado a cabo pelo CIES (Capucha et al., 2017), deu-se conta que a dimensão reduzida das turmas beneficiava sobretudo os alunos mais vulneráveis e desfavorecidos. Tal parece ainda mais relevante se tivermos que contemplar e agilizar novamente processos de ensino à distância, ou num registo presencial que obrigue a distanciamento entre os participantes de uma sala de aula (professores e alunos).

A melhoria da comunicação em espaço escolar parece ser outra questão a considerar. A dotação da administração escolar, não apenas de sistemas de informação sobre os seus alunos, que, aliás, tem tido um grande incremento nos últimos anos, mas também de comunicação. Só em 27\% das nossas escolas CITE 1, 49\% das CITE 2 e $43 \%$ das CITE 3, os alunos (em mais de 50\%) têm endereço de e-mail institucional da escola a que pertencem. Tais dados dão conta de uma enorme distância das escolas da Suécia $(90 \%, 97 \%$ e $96 \%$, respetivamente), da Islândia (90\%, $90 \%$ e 55\%, pela mesma ordem das CITE) ou da Finlândia (onde os valores são 79\%, 86\% e 99\%) (Comissão Europeia, 2019). Ou seja, uma direção escolar, sobretudo daqui para a frente, terá que sofisticar o seu sistema de comunicação com os alunos e as famílias. Aliado a estas medidas de comunicação poderá estar também o próprio desenho de uma estratégia de prevenção do abandono escolar. 
A promoção do acesso ao ensino superior, mesmo para os que estiveram em vias profissionais ou noutras vias alternativas, com muito riscos associados na transição para uma aprendizagem exclusivamente digital (CEDEFOP, 2020), é determinante. Os sistemas educativos mais avançados já massificaram o ensino superior na sua população em idade ativa. A prioridade dada ao seu acesso é, portanto, justificada.

Para finalizar, a análise permite ainda refletir os arranjos variados, onde são peças essenciais a autonomia das escolas, os recursos que têm disponíveis e a capacitação dos atores escolares.

Terminamos assim como começámos, levantando o véu sobre alguns dos problemas que atingiram as escolas e os sistemas educativos, mas ainda longe das conclusões finais sobre esta crise.

\section{Referências bibliográficas}

Almeida, Maria Antónia Pires de (2012), "O Porto e as epidemias: saúde e higiene na imprensa diária em períodos de crise sanitária, 1854-56, 1899, 1918", Revista de História da Sociedade e da Cultura, 12, pp. 371-391.

Banco Mundial (2020), How countries are using edtech (including online learning, radio, television, texting) to support access to remote learning during the COVID-19 pandemic.

Bernstein, Basil (1975), Language et Classe Social: Codes Socio-linguistiques et Contrôle Social, Paris, Les Éditions de Minuit.

Bourdieu, Pierre; e Jean-Claude Passeron (1964), Les Héritiers: Les Étudiants et la Culture, Paris, Les Éditions de Minuit.

Bourdieu, Pierre; e Jean-Claude Passeron (1970), La Reproduction: Élements pour Théorie du Systéme de L'Enseignement, Paris, Minuit.

CEDEFOP (2020), Digital gap during COVID-19 for VET learners at risk in Europe.

Capucha, Luís (org.); Belmiro Cabrito; Helena Carvalho; João Sebastião; Susana da Cruz Martins; Ana Rita Capucha; Cristina Roldão; Inês Tavares; e Pedro Mucharreira (2017), A Dimensão das Turmas no Sistema Educativo Português: Relatório final, Lisboa, CIES-IUL. 
Coleman, James S. (org.), Ernest O. Campbell, Carol J. Hobson, James McPartland, Alexander M. Mood, Frederick D. Weinfeld, e Robert L. York (1966), Equality of Educational Opportunity, Washington, Government Printing Office.

Comissão Europeia (2019), 2nd Survey of Schools: ICT in Education Objective 1: Benchmark progress in ICT in schools, Luxemburgo, Publications Office of the European Union.

Di Pietro, Giorgio; Federico Biagi; Patricia Costa; Zbigniew Karpiński; e Jacopo Mazza (2020), The likely impact of COVID-19 on education: Reflections based on the existing literature and international datasets, EUR 30275 EN, Publications Office of the European Union, Luxembourg, 2020.

Eurydice (2019), Digital Education at School in Europe. Report, Luxembourg, Publications Office of the European Union, Comissão Europeia/EACEA/ Eurydice.

Green, Andy; John Preston; e Jan Germen Janmaat (2006), Education, Equality and Social Cohesion: A Comparative Analysis, Nova lorque, Palgrave.

Martins, Susana da Cruz (2017), "Expansão, desigualdades e desempenhos dos sistemas educativos: um olhar cruzado entre os dois lados do Atlântico", em M. G. J. Setton (Ed.), Mérito, Desigualdades e Diferenças: Cenários da (in)justiça escolar, Brasil e Portugal, São Paulo, Annablumme Editora.

Martins, Susana da Cruz; Rosário Mauritti; Nuno Nunes; Ana Lúcia Romão; e António Firmino da Costa (2016), "A educação ainda é importante para a mobilidade social? Uma perspetiva das desigualdades educacionais da Europa do Sul no contexto europeu", Revista Portuguesa de Educação, 29 (2), pp. 261-285.

Martins, Susana da Cruz; João Sebastião; Pedro Abrantes; e Maria de Lurdes Rodrigues (2018), "Desigualdades e políticas educativas. Portugal no Contexto Europeu" em R. Carmo e outros (orgs.), Desigualdades Sociais: Portugal e a Europa, Lisboa, Mundos Sociais, pp. 7-22.

Mateus, Sandra (2017), "Vantagens na desvantagem? Articulando marcadores de diferença na análise sociológica do sucesso escolar", em M.G. J. Setton (Ed.), Mérito, Desigualdades e Diferenças: cenários da (in)justiça escolar Brasil e Portugal, S. Paulo, Annablume, pp. 179-201. 
Nações Unidas (2020), Policy Brief: Education during COVID-19 and beyond.

OCDE (2019), PISA 2018 Results (Volume II): Where All Students Can Succeed, PISA, OECD Publishing, Paris.

Rodrigues, Maria de Lurdes; João Sebastião; João Trocado da Mata; Luís Capucha; Luísa Araújo; Mariana Vieira Silva; Susana da Cruz Martins; e Valter Lemos (2016), Educação. 30 Anos de Lei de Bases, Lisboa, Mundos Sociais.

Seabra, Teresa (2009). "Desigualdades escolares e desigualdades sociais", Sociologia, Problemas e Práticas, 59, pp. 75- 106.

Sebastião, João (2009), Democratização do Ensino, Desigualdades Sociais e Trajectórias Escolares, Lisboa, Fundação Calouste Gulbenkian.

Sobral, José Manuel; e Maria Luísa Lima (2018), "A epidemia da pneumónica em Portugal no seu tempo histórico", Ler História, 73, pp. 45-66.

UNESCO (2020), UNESCO - COVID-19 Resposta educacional, Nota Informativa 2.1 - Setor de Educação.

Fontes de informação

Banco Mundial

Direção-Geral da Saúde

Jornal Público

Ministério da Educação

Rádio Renascença 1

Rádio Renascença 2

The Guardian

UNESCO 
Entrevista realizada a Susana da Cruz Martins no âmbito da rubrica "Um olhar sociológico sobre a crise Covid-19", publicada a 16 de abril de 2020.

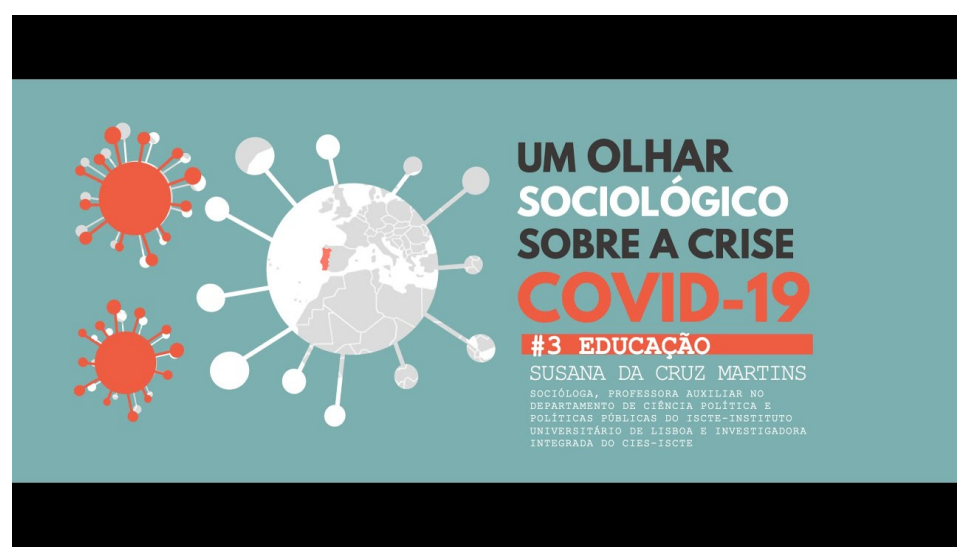




\section{CAPÍTULO 4}

O IMPACTO DA CRISE DA COVID-19 NAS DESIGUALDADES SOCIOLINGUÍSTICAS E ÉTNICO-RACIAIS

\section{Ana Raquel Matias}

Investigadora integrada e Professora Auxiliar Convidada no Iscte - Instituto Universitário de Lisboa, Investigadora no CIES-Iscte

Diversidade e desigualdades linguísticas - breve introdução

A nossa sociedade caracteriza-se por uma crescente presença de população de origem estrangeira, resultando na co-existência de indivíduos falantes de línguas de diferentes partes do mundo - e não só línguas oficiais dos diferentes países de que são originários, como também línguas regionais e locais que ultrapassam fronteiras nacionais. Esta é uma das consequências linguísticas dos fenómenos migratórios, ou seja, da mobilidade internacional de mulheres, homens, jovens e crianças, que trazem consigo toda uma riqueza de línguas. E face à presença dessas línguas na sociedade portuguesa, todos temos a possibilidade de, pelo menos potencialmente, aceder a diferentes culturas, à história e às normas de outras sociedades, a várias formas de conhecimento e legados científicos, a variadíssimas produções culturais, isto é, a tudo o que numa língua se transporta.

Atualmente, esta diversidade de línguas ecoa nos diferentes contextos laborais e sectores de atividade económica em todo o território nacional (por exemplo, turismo, comércio e serviços, construção civil, indústria, agricultura, cultura, habitação, ensino, saúde, etc.). Em termos geracionais, a população escolar do nosso sistema de ensino reflecte bem essa mudança demográfica (Oliveira e Gomes, 2017). Por exemplo, existem escolas na Área Metropolitana de Lisboa onde convivem mais de 80 nacionalidades diferentes, o que significa que a língua portuguesa, enquanto principal língua oficial de 
escolarização, convive nesses espaços escolares com mais de 50 línguas diferentes (Mateus, Pereira, e Fischer, 2008).

No entanto, o reconhecimento e a valorização da diversidade linguística presente no Portugal contemporâneo não é igual para cada uma destas línguas. A valorização social que lhes é atribuída depende menos do número dos seus falantes e mais do estatuto social que lhes é atribuído na sociedade portuguesa (Matias, 2017). Línguas "menorizadas"1 ou de origem imigrante como o cabo-verdiano provavelmente a segunda língua mais falada em Portugal, depois do português - não gozam do mesmo reconhecimento que o inglês, o francês ou o alemão. A importância social que aferimos a cada língua explica-se, em parte, na história das relações político-económicas entre os territórios implicados e respectivos falantes, mas também nessas mesmas dinâmicas à escala global. Por exemplo, a hegemonia internacional da língua inglesa, a recente valorização do mandarim, ou, por contrapartida, uma menor valorização social do russo ou do árabe - tudo línguas faladas por populações actualmente residentes em Portugal, com uma presença demográfica muitíssimo relevante à escala global, mas cuja relevância social depende da geopolítica internacional que influencia o território em que nos encontramos, neste caso as políticas da União Europeia.

Não sendo objectivo desta reflexão entrar em detalhe sobre esses processos, importa salientar que a forma como valorizamos e lidamos com cada uma das línguas em presença no território português é muito variada, e que esse tratamento diferenciado é independente do número de falantes que possam aqui residir. Esta diferenciação reflecte-se não apenas na disponibilização da informação e oferta de infraestruturas de literacia nestas línguas, como também nas escolhas de quais línguas usar na disseminação de informação cidadã a vários níveis: seja no acesso ao trabalho, à habitação, à educação, à saúde ou a uma

\footnotetext{
1 Ver discussão em Matias (2017) e Flores e Rosa (2015: 169), optando a autora pelo conceito de "menorização" por oposição à minoria, realçando os processos através dos quais a desvalorização linguística acontece.
} 
participação cidadã. Ou seja, os cidadãos residentes em Portugal não estarão todos no mesmo pé de igualdade no acesso à informação que necessitam para exercer os seus direitos e deveres se as línguas que melhor dominam não forem disponibilizadas, seja formal ou informalmente.

Diversidade linguística e o acesso à língua oficial

O reconhecimento que a diversidade linguística tem vindo a caracterizar a nossa sociedade motivou também um investimento significativo em políticas de ensino de língua portuguesa para a população não falante de português. Temos, assim, observado programas de ensino de Português Língua Não Materna (PLNM), Português para Falantes de Outras Línguas (PFOL), Português como Língua de Acolhimento (PLA), Português como Língua Segunda (PLS) ou Português como Língua Adicional (PLA). Esta tem sido uma das prioridades de há 20 anos para cá nas políticas de integração de populações de origem estrangeira, seja nas escolas portuguesas, nos centros de formação, instituições de ensino superior, organizações não governamentais, fundações privadas, associações locais, etc. (Matias, Oliveira e Ortiz, 2016).

No caso dos filhos de imigrantes em idade escolar, desde 2006 foi criada a disciplina de Português Língua Não Materna com o objectivo de permitir o acesso à língua de escolarização - neste momento existe oferta curricular para todos os níveis de ensino. No entanto, nem todas as escolas têm conseguido reunir as condições requeridas nas orientações desta medida educativa (Madeira et al., 2014), que estipulam turmas por níveis de escolaridade e níveis de conhecimentos na língua portuguesa, leccionadas por professores que possuam formação adequada. Observa-se antes a prática de turmas mistas em termos de níveis de escolaridade e de conhecimento da língua portuguesa, ou através de aulas de apoio extracurriculares. Adicionalmente, a generalidade dos docentes tem formação de ensino para falantes de português como língua materna, de ensino de outras línguas estrangeiras ou em educação básica do $1 .^{\circ}$ ciclo. Estas 
condicionantes têm óbvias implicações nos primeiros anos de integração destes alunos no sistema de ensino, podendo comprometer o seu sucesso escolar em todas as outras disciplinas.

No caso dos aprendentes adultos, a instabilidade profissional que pode caracterizar alguns destes aprendentes, assim como a sua difícil conciliação com necessidades familiares e os horários escolares, tem-se confrontado com uma inflexibilidade dos programas existentes ao nível dos horários e possibilidades de mudanças de turma. Também a necessidade de ter um documento de regularização válido para aceder a estes programas ou à sua certificação final tem sido um obstáculo. E, ainda, o facto da larga maioria destes programas estar pensada para um perfil de aprendente com níveis de literacia significativos. Em suma, os que vivem situações de maior vulnerabilidade, e para quem a aprendizagem da língua portuguesa (enquanto língua oficial) poderia constituir uma ferramenta de mobilidade social urgente no exercício dos seus direitos e criação de autonomia financeira perante maiores riscos de precariedade e exploração, são antes aqueles que mais dificuldades têm tido no acesso a estes programas (Matias, Oliveira e Ortiz, 2016).

Porquê focar na desigualdade linguística no actual contexto de crise?

Não há dúvida de que a pandemia trouxe a desigualdade linguística para o primeiro plano, de forma global e sem precedentes, e continuará a moldar as agendas de investigação sociolinguística durante algum tempo (Piller, 2020). ${ }^{2}$

\footnotetext{
2 Tradução da autora: "There is no doubt that the pandemic has brought linguistic inequality to the fore in globally unprecedented ways and will continue to shape sociolinguistic research agendas for some time to come". Em Ingrid Piller (24 abril 2020), Language on the Move, "Language challenges of Covid-19 are a pressing issue - Language and health".
} 
Um dos aspectos chave para a contenção de doenças contagiosas é efectivamente a comunicação de informação sobre saúde pública. Sendo a actual crise caracterizada pela significativa diminuição da mobilidade de pessoas e mercadorias, acompanhada por um crescente fluxo de informação, as tecnologias de informação tornaram-se imprescindíveis na prevenção e controlo de epidemias (Ortega, 2020). E porque sabemos também que 0 acesso às tecnologias é um dos principais factores de aceleramento das desigualdades sociais, aqui o papel das tecnologias na disponibilização de informação social em saúde é ainda mais crucial para todos aqueles que não têm acesso a informação suficientemente fiável mas são inundados com informação de origem duvidosa (a designada "pandemia de desinformação"). ${ }^{3}$

Há muito que se discute que um dos eixos fundamentais no combate às desigualdades reside no desenvolvimento de possibilidades de os cidadãos adquirirem competências que thes permitam usufruir de forma crítica e confiante as tecnologias de informação social (Ortega, 2020). Desde 2006 que na União Europeia se integraram as competências digitais numa lista de oito competências essenciais e interdependentes para a aprendizagem ao longo da vida, desde a idade pré-escolar até à idade pós-reforma (Comissão Europeia, 2006). ${ }^{4}$ Entre estas, encontramos as competências digitais, as competências de comunicação na língua materna e em línguas estrangeiras, as competências básicas em ciências e tecnologia e de sensibilidade e expressão culturais - todas questões centrais na presente discussão. Também se tem reconhecido que algumas categorias populacionais apresentam maiores riscos de se constituírem numa subclasse digital (digital underclass) (Ortega, 2020),

3 "Infodemic" em inglês. Ver a este propósito a recente anunciada colaboração da Organização Mundial de Saúde (OMS) com a Wikipédia, na promoção e realização de recursos de livre acesso dedicados à Covid-19, atualmente disponibilizados em cerca de 175 línguas.

4 Ver Recomendação do Parlamento Europeu e do Conselho, 18 dezembro 2006, sobre as competências essenciais para a aprendizagem ao longo da vida (2006/962/CE). 
nomeadamente populações com baixos graus de literacia, jovens em situação de abandono escolar precoce, desempregados de longa duração, trabalhadores em períodos de licença prolongados, idosos, pessoas com deficiência e, justamente, os migrantes (Comissão Europeia, 2006). Falamos, assim, de condicionantes que podem gerar dificuldades na consulta de informação de saúde médica sobre o vírus; no acesso e usufruto de consultas de telemedicina; no preenchimento de requerimentos de apoio ao desemprego, rendas de habitação e outros; e mesmo na orientação da escolaridade dos filhos a partir de casa.

Adicionalmente, não será demais lembrar que as condições de saúde dos cidadãos dependem de vários factores (Ortega, 2020), nomeadamente do seu estatuto socioeconómico; da sua ocupação profissional (profissionais na linha da frente, trabalhadores essenciais); das infraestruturas existentes (higiene urbana, condições habitacionais e laborais); do seu acesso às ofertas de cuidados de saúde; e do estatuto social racializado que lhes é atribuído. De facto, muitas das populações falantes de línguas "menorizadas" encontram-se sobrepresentadas em profissões essenciais (sectores como agricultura, lacticínios, aviários, construção civil, limpezas, motoristas de táxis, serviços de venda a retalho (Piller, 2016; Van Bavel et al., 2020, citados por Ortega, 2020). Muitas destas profissões caracterizam-se por relações laborais precárias e/ou tendo condições de risco para a saúde - constituindo-se os seus profissionais potenciais grupos de risco face à Covid-19. Adicionalmente, muito do trabalho científico dedicado ao impacto da diversidade linguística nas sociedades contemporâneas tem procurado desconstruir as relações históricas do impacto do racismo na diversidade linguística em presença, chamando a atenção para a interseccionalidade histórica entre noções de diversidade linguística, de raça, racismo e populações socialmente racializadas (como por exemplo: raciolinguística de Flores e Rosa, 2015 e interseccionalidade de Crenshaw, 1989, citada por Ortega, 2020). E porque estas correlações são estruturais e históricas, e se reflectem nas 
condicionantes acima referidas, os seus efeitos são, consequentemente, visíveis nas desigualdades implicadas no acesso à saúde.

Importa, então, perguntar como é que a crise pandémica Covid-19 tem tornado mais complexa a inclusão de populações multilingues mais vulneráveis. A resposta deverá começar pela constatação de que a língua é um elemento crucial na mediação do acesso à saúde, da qual depende, primeiramente, a compreensão da informação disponível e, segundamente, o conhecimento sobre a qualidade dos cuidados de saúde aos quais se necessita aceder. As barreiras linguísticas podem, assim, comprometer de forma grave a actualização e a qualidade da informação de saúde pública acessível a populações linguisticamente diversas, sobretudo se socialmente desfavorecidas. Um plano de serviços linguísticos de resposta a emergências deveria ser incluído na prevenção e controlo de emergências públicas, constituindo por si só um teste à sua gestão (Ortega, 2020) - questão que será retomada mais adiante. As autoridades oficiais têm aqui um papel chave enquanto canais de inclusão ou exclusão no acesso à saúde, através das suas políticas linguísticas nesta área.

Pistas internacionais sobre o impacto da Covid-19 em populações linguisticamente diversas

Em Março de 2020 o site Language on the Move5, e a sua revista Multilingua, lançaram uma chamada de artigos científicos para um número especial que desse conta do impacto da pandemia Covid-19 sobre populações linguisticamente diversas em várias partes do

5 Language on the Move é um site de investigação sociolinguística com revisão de pares, que tem como objectivo divulgar a investigação sociolinguística a um vasto público à escala global e cujos trabalhos incidem sobre multilinguismo, aprendizagem de línguas, e comunicação intercultural nos contextos da globalização e migração. Ver aqui. 
mundo6. As expectativas do desafio lançado foram largamente superadas, ao receberem mais de 200 artigos (dez vezes mais do que tinham previsto) de trabalhos científicos oriundos de mais de 30 países, com particular destaque para o hemisfério Sul do planeta. Face à adesão recebida, os organizadores decidiram alargar os seus fóruns sociolinguísticos sobre a Covid-19, editando um número especial acerca da investigação sociolinguística sobre os efeitos da pandemia na China; promovendo Covid-19 Archives com informação de vários países dedicadas aos desafios linguísticos da Covid-197; e abrindo a possibilidade de submissão de artigos individuais sobre os desafios linguísticos da Covid-19 até 2022. ${ }^{8}$

O conjunto de trabalhos submetidos permitiu ainda realizar um balanço dos temas e preocupações fundamentais dos estudos existentes sobre o impacto da diversidade linguística das sociedades contemporâneas, a partir do qual foi possível retirar cinco grandes conclusões:

1. Observa-se, em diferentes países e regiões, limitações linguísticas na informação governamental sobre saúde pública e outras

6 Nome da publicação: "Linguistic diversity and public health: sociolinguistic perspectives on Covid-19 (Diversidade linguística e saúde pública: perspectivas sociolinguísticas sobre a Covid-19 - tradução da autora)" editada por Ingrid Piller (Macquarie University, Sydney), Jie Zhang (Zhongnan University of Economics and Law, Wuhan) e Jia Li (Yunnan University, Kunming). Ver também aqui.

7 Ver aqui.

8 Observa-se o mesmo para outras plataformas e iniciativas, como por exemplo as chamadas de artigos referidas na página Language on the Move, nomeadamente um número especial sob o nome: "Indigenous Innovation in Higher Education during the Corona-virus pandemic" do Journal of Global Indigeneity; o trabalho de recolha de trabalhos no website Language resources do International Year of Indigenous Languages 2019; a campanha \#ResearchAcrossBoarders lançada pela Fundação Humboldt - the Humboldt Network on the Corona Pandemic - envolvendo investigadores de variadíssimos domínios científicos (ver, por exemplo, 16 vídeos com investigadores da África do Sul, Alemanha, Argentina, Benin, China, EUA, Israel, Maurícias e Nigéria, aqui e aqui). 
comunicações de serviço público dirigidas a populações linguisticamente diversas;

2. Destacam-se problemas relacionados com a tradução e normas terminológicas multilingues em informação sobre saúde pública e investigação médica, cuja pouca sensibilidade à diversidade cultural aumenta o risco de menor eficácia comunicacional para com as populações-alvo;

3. Observa-se o reforço das desigualdades na saúde com a crise Covid-19, justificada por uma maior inacessibilidade à informação sobre saúde pública por parte dos grupos desfavorecidos, incluindo aqui populações indígenas, migrantes e refugiados e pessoas com diferentes tipos de deficiência. Esta questão tem merecido particular destaque na ONU9 e na disseminação das estatísticas por categorias étnico-raciais de casos de infecção, hospitalização e morte por Covid-19;10

4. Constata-se a necessidade urgente de investir numa análise crítica sobre o crescente uso de linguagem racista e discriminatória aquando a discussão sobre saúde pública, com particular destaque para os discursos produzidos nos meios políticos, na comunicação social, nas plataformas digitais várias e no espaço público físico no geral;

5. Ainda assim, observa-se um reforço de estratégias de gestão da diversidade linguística, de cima para baixo e de baixo para cima, com o objectivo de ultrapassar as barreiras linguísticas observadas. Aqui, uma questão importante e positiva reside na importância de uma efectiva coordenação entre as diferentes entidades envolvidas nas decisões a várias escalas, ou seja, implicando a sociedade civil e as associações que estão no terreno a trabalhar com as populações-alvo. Portanto, estes estudos permitiram demonstrar que uma horizontalidade na

\footnotetext{
9 Tendência reforçada a Junho de 2020, por Michelle Bachelet, Alta Comissária para os Direitos Humanos, Conselho para os Direitos Humanos, Organização das Nações Unidas. Ver aqui.

10 Ver, por exemplo, nos EUA, Centers for Disease Control and Prevention, 2020 (ver aqui) e Yaphet et al., 2020 (ver aqui), em França, Pascual, 2020 (ver aqui) ou no Reino Unido, Mclntyre, 2020 ( ver aqui).
} 
forma de abordar as questões colocadas e na tomada da decisão, leva a uma maior eficácia na resolução dos problemas, por contraste às decisões tomadas de cima para baixo com pouca participação e controlo na forma como as medidas são posteriormente operacionalizadas no terreno e junto das populações-alvo - isto seja na escolha das medidas a implementar, seja nas estratégias de acesso à informação.

O contexto português no impacto da pandemia Covid-19

Entre a população adulta estrangeira, os que mais dificuldades têm tido no acesso a programas de ensino da língua portuguesa serão exactamente aqueles que estarão menos seguros no acesso à informação de saúde pública e informação médica certificada, quando divulgada em língua portuguesa. São, por isso, aqueles que se encontram em situação de grande desvantagem nas suas tomadas de decisões de forma mais adequada - seja ao nível da família, da comunidade, do trabalho e da escolaridade dos filhos. Reconhecendo que estas dificuldades existem, as entidades governamentais e não-governamentais responsáveis têm alargado os meios e plataformas de comunicação num número cada vez mais diversificado de línguas. Mas a operacionalização dessa informação junto destas populações depende muito de quem trabalha no terreno. E nem sempre as instituições responsáveis dispõem dos recursos necessários para chegar junto das pessoas mais necessitadas e, consequentemente, acompanhá-las no acesso à informação e esclarecimento necessários para que estes possam ser encaminhados da forma mais adequada, e tomar as suas decisões autonomamente.

No primeiro semestre de 2020 estas limitações foram por demais evidentes no caso dos requerentes de asilo. A urgência das necessidades vividas por estes cidadãos tornou-se gritante a vários níveis: no acesso à habitação, à alimentação, ao trabalho e à informação de saúde pública necessária. Ainda hoje persistem as limitações linguísticas e de sensibilidade cultural na informação e disponibilização 
sobre saúde pública, que já eram problemas diagnosticados antes da pandemia da Covid-1911. Destaca-se a necessidade de intérpretes e tradutores profissionais conhecedores da realidade desta população, dos seus processos legais, das suas línguas e práticas culturais a nível da saúde e cuidados de saúde - de forma a poder proporcionar um sentimento de segurança para estas populações e para aqueles que com elas trabalham.

Por outro lado, o fenómeno da Covid-19 obrigou professores e aprendentes a ensinar e aprender online, implicando conhecimentos prévios de literacia digital e disponibilidade de recursos adequados (Ortega, 2020). Embora nos últimos anos a integração da tecnologia no ensino tenha avançado em termos de adequação de recursos, pela primeira vez milhares de professores e aprendentes viram-se obrigados a confiar no ensino e aprendizagem online. Só que nem todos estariam preparados para este desafio e nem sempre os apoios disponibilizados pelas infra-estruturas locais seriam os mais adequados. Esta utilização repentina e generalizada das tecnologias online pôs a descoberto os efeitos da desigualdade de acesso a infra-estruturas e recursos. Encerradas as bibliotecas e outros locais de acesso público à internet, os pais viram-se obrigados a assumir a orientação antes estruturada pela escola, tornando toda a família ainda mais dependente da língua maioritária e do conhecimento digital prévio para levar a cabo o processo de aprendizagem dos filhos - gestão difícil para pais multilingues com recursos económicos e digitais limitados.

No caso das famílias com maiores dificuldades, a passagem para o formato digital e para a telescola acentuaram as dificuldades já observadas com o PLNM. Na impossibilidade de uma interacção com o professor mais espontânea e continuada que o contexto presencial permitiria, os alunos ficaram muito dependentes do acompanhamento ainda possível dos seus professores de PLNM através do formato digital

11 Ver Santinho, Rebelo e Cardoso (2020a; 2020b) no jornal o Público em Maio de 2020, "Aㅡ covid-19 e o descortinar das práticas do sistema de asilo português", e no blog da Faculdade de Direito da Universidade de Oxford, Reino Unido, em Junho de 2020. 
ou, nos casos em que tal deixou de ser possível, pela telescola. E mesmo que a telescola tenha oferecido a disciplina de PLNM, esta oferta não foi direccionada para os diferentes níveis de ensino, ao contrário das outras disciplinas. ${ }^{12}$ A grelha da telescola propunha aulas PLNM simultaneamente para todos os alunos do $1 .^{\circ}$ ao $9 .^{\circ}$ ano, diferenciando apenas entre os níveis de iniciação e intermédio. Visto que nem todos os alunos estão no mesmo nível de aprendizagem nem apresentam o mesmo nível de necessidades de aprendizagem, seja pelo seu nível de escolaridade, seja pelo seu nível de conhecimento da língua portuguesa, as actuais condicionantes acentuaram eventuais dificuldades do processo de aprendizagem, sobretudo quando a interacção com os professores foi substancialmente diminuída ou mesmo suprimida.

\section{A propagação de linguagem discriminatória e racista}

A propagação de linguagem discriminatória e racista que podemos observar desde o início da pandemia Covid-19 é, por um lado, motivada pela construção mediática sobre a origem do vírus e o seu impacto em diferentes populações e, por outro lado, pela "pandemia de informação" enganosa crescente. Desde logo, na forma como as narrativas focaram a China como responsável pela pandemia ("the Kung Flu", "Chinese flu" ou "China vírus")13, levando a que diferentes comunidades de origem asiática espalhadas pelo mundo sofressem actos de discriminação e racismo. Num segundo plano, observa-se a construção de uma retórica sobre necessidades e riscos específicos de

\footnotetext{
12 Estudo em Casa - Grelha da semana.
}

13 Janeiro de 2020, Le Monde; Março de 2020, New York Times; Maio de 2020, BBC News; Documentos-relatórios sobre os media e experiências individuais nos EUA, um dos países mais atingidos pela pandemia Covid-19 a nível mundial: Coronavirus discrimination in the News (the Asian Pacific Planning and Policy Council (A3PCON), Chinese for Affirmative Action (CAA), San Francisco State University, Asian American Studies); Stop AAPI Hate Reporting Center; Abril de 2020, New Center for Public Integrity/lpsos Poll. 
populações particularmente vulneráveis - nem sempre motivadas pelas razões anteriormente explicadas, antes reactivando memórias históricas de racismo e discriminação. Todas estas preocupações têm sido alertadas pela Organização Mundial de Saúde e o Human Rights Watch ${ }^{14}$, pelas Nações Unidas (como já referido acima) e, no plano nacional, a partir de uma larga plataforma de colectivos e cidadãos antiracistas ${ }^{15}$.

Em Portugal assiste-se, infelizmente, à propagação deste tipo de linguagem, como se poderá recordar na forma como em Maio de 2020 um meio de comunicação social discutiu a proposta de um partido de extrema direita sobre medidas de confinamento específicas para as comunidades ciganas em Portugal. Utilizaram o mesmo tipo de linguagem e não consideraram como interlocutores legítimos os representantes das comunidades respetivas ${ }^{16}$. Outro caso foi a forma como em Abril de 2020 foram abordadas as necessidades urgentes de requerentes de asilo em Portugal em tempos de pandemia;17 ou, ainda, na forma como foi retratado o caso dos cidadãos de origem estrangeira que, por necessidades económicas graves, se dirigiram em massa aos serviços de solidariedade numa mesquita na Amadora. ${ }^{18}$

\footnotetext{
14 Human Rights Watch; Maio de 2020, National Geographic.

15 Ver aqui.
}

16 Ver Fórum TSF: "André Ventura propõe plano de confinamento para a comunidade cigana", 7 de Maio de 2020; e "Entidade Reguladora para a Comunicação Social (ERC) recebe participações contra TSF sobre Fórum relativo a proposta do Chega", 12 de Maio de 2020.

17 Requerentes de Asilo (Abril de 2020), no jornal o Público (ver aqui e aqui) e no jornal Correio da Manhã (ver aqui).

18 Mesquita da Amadora (Maio de 2020), na revista Sábado; na TVI24; e na SIC Notícias. 
Será possível mitigar as desigualdades sociolinguísticas e as procedentes desigualdades sociais?

Em jeito de conclusão, gostaria de tentar delinear possíveis respostas a esta pergunta, em cinco pontos.

Primeiro, dos vários impactos da pandemia Covid-19, há uma lição positiva a retirar, seja em Portugal como em muitos outros contextos do planeta: qualquer intervenção será sempre mais eficaz quanto mais colaborativa for (e a várias escalas). No caso urgente dos requerentes de asilo em Portugal, a intervenção de emergência realizada num curto espaço de tempo foi mais eficaz a partir do momento que as entidades governamentais trabalharam junto com as entidades não governamentais responsáveis pelo acolhimento e com as associações que trabalham com mais proximidade junto destes cidadãos. Retira-se daqui que as estratégias de acolhimento no futuro deverão ser discutidas o mais horizontalmente possível, aproveitando o conhecimento que cada instituição e organização tem adquirido e acumulado ao longo do tempo. É na partilha dessa informação e no trabalho colaborativo que a resposta oferecida tem, continuamente e em múltiplos contextos nacionais e continentais, se revelado mais adequada.

Segundo, confirma-se a necessidade urgente de intérpretes e tradutores, não só em número como sobretudo detentores das competências necessárias, para que as respostas sejam efectivamente adequadas à realidade em causa. $\bigcirc$ recurso a mediadores linguísticos e culturais informais e voluntários gera novas pressões com a Covid-19 que vão para lá da interpretação/tradução. Muitas vezes são crianças, jovens, esposos, outros familiares ou conhecidos, nem sempre bem acolhidos nas instituições de saúde (Cox et al., 2019; Flores et al., 2012, citados por Ortega, 2020), e cuja prática pode originar tensões face aos riscos de imprecisões, erros e desadequação de tópicos não negligenciáveis. Sabendo que o número de profissionais de saúde com competências para cumprir este papel é ainda escasso, corre-se o risco de observar graves consequências para a saúde, pela consequente 
demora na tomada de decisão na procura de apoio médico; na identificação da instituição de saúde onde se dirigir e dos meios de transporte necessários; na forma de receber cuidados adequados na instituição de saúde em causa (Ortega, 2020).

Não pretendendo desvalorizar o esforço da ajuda voluntária e tradução/interpretação face à inexistência de outras respostas, importa, ainda assim, assumir que o nível de competências implicado neste tipo de trabalho é exigente. Tratam-se de competências que implicam conhecimentos sobre os contextos de origem e as referências culturais das populações junto das quais se pretende intervir, sendo igualmente importante saber aferir o nível de conhecimento em diferentes línguas da população-alvo e as necessidades a este nível; ter conhecimento dos processos de legalização em território nacional (variando entre requerentes de asilo, refugiados ou estrangeiros com a situação regularizada em Portugal); e, finalmente, ter formação sobre como disseminar informação médica certificada e de saúde pública. No seu todo, falamos de níveis de exigência de conhecimento e competências bastante elevados, e só uma formação adequada e acompanhada, que permita a colaboração entre as entidades no terreno com as entidades governamentais, poderá, a longo prazo, dar respostas mais eficazes não só às populações mais vulneráveis como para todos os que necessitem destes serviços.

Terceiro, sabendo que o acesso à tecnologia acelera as desigualdades sociais existentes, é urgente dar um foco prioritário às necessidades de aquisição de literacia digital. Destacam-se aqui propostas globalmente trabalhadas e que suscitaram outra chamada de artigos: ${ }^{19}$

19 Ver, por exemplo, chamada de artigos em Elsevier Journals "Teaching and learning languages online: Challenges and responses" edited by Xuesong (Andy) Gao, School of Education, the University of New South Wales, Sydney, Australia; Jian (Tracy) Tao, School of Foreign Studies, Shanghai University of Finance and Economics, Shanghai, China. 
- Conceber actividades de aprendizagem online eficazes e envolventes, de forma a motivar aprendentes para uma aprendizagem eficaz;

- Criar espaços de partilha de experiências de ensino online entre professores, procurando reflectir como serão estas experiências no longo prazo;

- Preparar adequadamente os professores de línguas para o ensino online;

- Desenvolver comunidades online para alunos e professores de línguas;

- Avaliar o progresso dos alunos de línguas e apoiá-los nas suas necessidades de progresso;

- Disponibilizar apoio e envolvimento técnico às famílias no uso das plataformas online.

E porque os estudos existentes têm persistentemente chamado a atenção à ausência de respostas eficazes para uma melhor interpretação e comunicação intercultural/transcultural em contextos de saúde, parece igualmente importante definir estratégias concertadas no trabalho da investigação científica. Nomeadamente, insistindo na produção sistemática dos resultados da investigação sobre a relação entre desigualdades sociais e desigualdades linguísticas, ainda muito dispersa (Ortega, 2020); promovendo a colaboração interdisciplinar com investigadores na área da saúde de diferentes domínios científicos (por exemplo, \#ResearchAcrossBorders, \#Covid19, \#Corona, ver nota de rodapé 8); promover a escuta e recolha das experiências de jovens multilingues e respectivas famílias; dar particular atenção às profissões onde se concentram maior número de trabalhadores/as falantes de outras línguas; e ter presente que na base de uma sociedade multilingue reside uma relação histórica estruturante entre noções de diversidade linguística, de raça e de racismo de populações socialmente racializadas (Flores e Rosa, 2015; Crenshaw, 1989, citada por Ortega, 2020). 
Finalmente, as populações mais vulneráveis, sejam estrangeiras ou nacionais, estão na linha da frente do embate da crise económica gerada pela pandemia Covid-19. São os trabalhadores com relações laborais mais frágeis, e com recursos económicos mais instáveis, os principais atingidos, e os estrangeiros com relações contratuais mais descartáveis os primeiros a perder os seus postos de trabalho e a sofrer uma redução dos recursos económicos. Face aos níveis de crescimento de pobreza que se tem observado, algumas entidades, governamentais, inter-governamentais e não-governamentais têm estado preocupadas com a possibilidade de regressão dos níveis de exploração actuais de cidadãos mais vulneráveis. ${ }^{20}$ Será por isso urgente definir como prioritário o acompanhamento adequado destas populações. Somos todos partes da mesma comunidade, nacionais e estrangeiros, e o bem de uns será com certeza o bem de todos.

\section{Referências bibliográficas}

Comissão Europeia (2006), Recomendação do Parlamento Europeu e do Conselho, 18 dezembro 2006, sobre as competências essenciais para a aprendizagem ao longo da vida.

Flores, Nelson; e Jonathan Rosa (2015), "Undoing Appropriateness: Raciolinguistic Ideologies and Language Diversity in Education", em Harvard Educational Review, Vol. 85 (2), pp. 149-171.

Madeira, Ana (coord.) (2014), Avaliação de Impacto e Medidas Prospectivas para a Oferta do Português Língua Não Materna (PLNM) no Sistema Educativo Português, FCSH/Universidade Nova de Lisboa, DGE.

Mateus, Maria Helena; Dulce Pereira; e Glória Fischer (2008), Diversidade Linguística na Escola Portuguesa, ILTEC/FCG.

Matias, Ana Raquel; Nuno Oliveira; e Alejandra Ortiz (2016), "Implementing training in Portuguese for Speakers of Other Languages in Portugal: the case of adult immigrants with little or no schooling", em Language And Intercultural Communication, Vol. 16 (1), pp.1-18.

20 UNODC (2020), COVID-19 response; Rádio Renascença, Maio de 2020. 
Matias, Ana Raquel (2017), "O lugar das línguas imigrantes não-europeias na sociologia das migrações internacionais", em Padilla, Beatriz; Joana Azevedo e Thais França (orgs.), Migrações Internacionais e Políticas Públicas Portuguesas, Lisboa, Mundos Sociais, pp. 151-172.

Oliveira, Catarina Reis; e Gomes, Natália (2017), "Estudantes estrangeiros nos diferentes níveis de ensino", Boletim Estatístico OM N³, Coleção Imigração em Números, Observatório das Migrações.

Ortega, Lourdes (2020), "How is COVID-19 affecting second language acquisition?", em The 2020 Einar Haugen Lecture, Center for Multilingualism in Society Across Lifespan, aula apresentada na University of Oslo, 23 Setembro 2020, Oslo.

Seabra, Teresa; Sandra Mateus; Ana Raquel Matias; e Cristina Roldão (2018), "Imigração e Escolaridade: Trajetos e Condições de Integração", em Carmo, Renato Miguel do, João Sebastião, Susana Cruz Martins, Joana Azevedo, António Firmino da Costa (coord.), Desigualdades Sociais: Portugal e a Europa, vol. III. Migrações, Fluxos e Espaços, Mundos Sociais ed. , Lisboa, pp. 301-314.

Textos, artigos, blog de um Website

AAVV (2020), "Covid-19: a luta antirracista não faz quarentena", em Opinião Coronavírus Público, data de edição: 13.04.2020, consultado em 23.10.2020.

Acácio, Manuel (2020), "André Ventura propõe plano de confinamento para a comunidade cigana", em Sociedade. Política. Fórum TSF, data de edição: 07.05.2020, consultado em 23.10.2020.

Asian American Pacific Islander (AAPI) (2020), Civil Rights Organizations, Stop AAPI Hate Reporting Center.

Bachelet, Michelle (Alta Comissária para os Direitos Humanos, Organização das Nações Unidas), "Global update on human rights and the impact of the COVID-19 pandemic", 30 de Junho de 2020, comunicação apresentada na 44. ${ }^{\text {a }}$ sessão do Conselho para os Direitos Humanos, consultado em 23.10.2020. 
Botelho, Leonete (2020), "Requerentes de asilo transferidos para Santa Margarida recusaram-se a sair do autocarro", em Coronavírus. Público, data de edição: 21.05.2020, consultado em 23.10.2020.

Cebron, Valentin e Pauline Petit (2020), "« Garde ton virus, sale Chinoise!» : avec le coronavirus, le racisme antiasiatique se propage en France", em Planéte Societé Le Monde, data de edição: 29.01.2020, consultado em 23.10.2020.

Centres for Disease Control and Prevention (CDC Gov) (2020), Covid-19 Cases, Hospitalization, and Death by Race/Ethnicity, data de edição: 08.08.2020, EUA, consultado em 23.10.2020.

Curado, Miguel e João Carlos Rodrigues (2020), "Refugiados de hostel com coronavírus em fuga ocultam paradeiro", em Sociedade. Correio da Manhã, data de edição: 24.04.2020, consultado em 23.10.2020.

\#EstudoEmCasa - Grelha da semana, RTP Memória, www.rtp.pt/estudoemcasa, consultado em 23.10.2020.

Ga, Xuesong A., Jian T. Tao (eds.) (2020), "Teaching and learning languages online: Challenges and responses", in Elsevier Journals, consultado em 23.10.2020.

Helier Cheung, Helier, Zhaoyin Feng e Boer Deng (2020), "Coronavirus: What attacks on Asians reveal about American identity", em Coronavirus pandemic BBC News data de edição: 27.05.2020, consultado em 23.10.2020.

Human Rights Watch (2020), "Covid-19 Fueling Anti-Asian Racism and Xenophobia Worldwide. National Action Plans Needed to Counter Intolerance", 12 de Maio de 2020, consultado em 23.10.2020.

The Humboldt Foundation (2020) Coronavirus Pandemic \#ResearchAcrossBoarders, consultado em 23.10.2020. Ver também aqui.

International Year of Indigenous Languages 2019 (2020), "Covid-19 Pandemic: Language Matters", consultado em 23.10.2020.

Jeung, Russell, Sarah Gowing e Kara Takasaki (2020), "News Accounts of Covid-19 Discrimination 2/9-3/7/20. Executive Summary", A Report for the Asian Pacific Planning and Policy Council (A3PCON), Chinese for Affirmative Action (CAA), San Francisco State University Asian American Studies, entre 9 de Fevereiro a 7 de Março 2020, consultado em 23.10.2020. 
Mclntyre, Niamh (2020), "Black men in England three times more likely to die of Covid-19 than white men", em UK Society. the Guardian, data de edição: 19.06.2020, consultado em 19.06.2020.

New Center for Public Integrity (2020), "Ipsos Poll finds most Americans say the Coronavirus Pandemic is a Natural Disaster", Abril de 2020, consultado em 23.10.2020.

Pascual, Julia (2020), "Immigrés : une mortalité deux fois plus élevée face à la pandémie de Covid-19", em Societé, Imigration et Diversité Le Monde, data de edição: 07.07.2020, consultado em 23.10.2020.

Piller, Ingrid, Jie Zhang e Jia Li (ed.) Language on the Move (2020, online), "Language challenges of Covid-19 are a pressing issue - Language and health", Language on the Move, 24 abril 2020), consultado em 23.10.2020.

Pincha, João Pedro (2020), "Há mais pensões sobrelotadas em Lisboa, o que faz temer explosão de casos", em Coronavírus. Público, data de edição: 21.04.2020, consultado em 23.10.2020.

Roque, Ângela (2020), "Tráfico humano. "A pandemia fortaleceu as vulnerabilidades de quem já era explorado" ", em Entrevista a Gabriella Bottani. Rádio Renascença, data de edição: 19.05.2020, consultado em 23.10.2020.

Santinho, Cristina, Dora Rebelo e Sílvia Cardoso (2020a), "A covid-19 e o descortinar das práticas do sistema de asilo português", em Opinião o Público, data de edição: 31.05.2020, consultado em 23.10.2020.

Santinho, Cristina, Dora Rebelo e Sílvia Cardoso (2020b), "Covid-19, the "Undercover" Portuguese Asylum System, and Its Jerry-Riggings", em Border Criminologies blog da Faculdade de Direito da Universidade de Oxford, Reino Unido, data de edição: 30.06.2020, consultado em 23.10.2020.

Strochlic, Nina (2020), "America's long history of scapegoating its Asian citizens", em History \& Culture - National Geographic, data de edição: 02.09.2020, consultado em 23.10.2020.

Tavernise, Sabrina e Richard A. Oppel Jr. (2020), "Spit On, Yelled At, Attacked: Chinese-Americans Fear for Their Safety", em the New York Times, data de edição: 23.03.2020, consultado em 23.10.2020. 
Yaphet Getachew et al. (2020), Beyond the Case Count: The Wide-Ranging Disparities of COVID-19 in the United States (Commonwealth Fund, Sept. 2020). data de edição: 10.09.2020, consultado em 23.10.2020. Ver também aqui.

United Nations Office on Drugs and Crimes (UNODC) (2020), Impacto da Pandemia Covid-19 no Tráfico de Pessoas. Conclusões preliminares e mensagens com base em um rápido balanço", em Covid-19 Response ONU, consultado em 23.10.2020.

Artigos de jornal sem autor identificado:

(2020) "Fila com mais de 300 pessoas na Amadora por um saco de comida", em TVI24, data de edição: 06.05.2020, consultado em 23.10.2020.

(2020) "Confusão em distribuição de alimentos na Amadora acalmou com a presença da polícia", em Coronavírus. SIC Notícias, data de edição: 06.05.2020, consultado em 23.10.2020.

(2020) "OMS e Wikipédia anunciam colaboração para combater desinformação sobre coronavírus", Covid-19 Lusa, Jornal o Público data de edição: 22.10.2020, consultado em 23.10.2020.

Agência Lusa (2020), "Covid-19: Mesquita da Amadora ajuda pessoas que ainda "vivem à luz de velas"", em Coronavírus. Portugal. Sábado, data de edição: 07.05.2020, consultado em 23.10.2020.

Agência Lusa (2020), "Entidade Reguladora para a Comunicação Social (ERC) recebe participações contra TSF sobre Fórum relativo a proposta do Chega", em Sociedade Observador, data de edição: 12.05.2020, consultado em 23.10.2020. 
Entrevista realizada a Ana Raquel Matias no âmbito da rubrica "Um olhar sociológico sobre a crise Covid-19", publicada a 15 de maio de 2020.

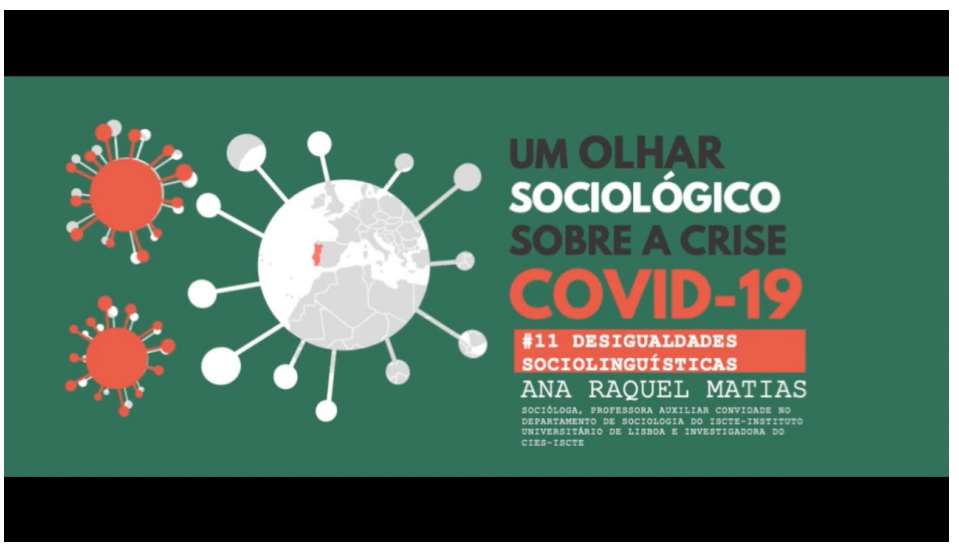




\section{CAPÍTULO 5}

\section{ELOGIO DA CO-PRESENÇA NO ENSINO SUPERIOR: BREVES NOTAS}

\section{João Teixeira Lopes}

Sociólogo, Professor da Faculdade de Letras da Universidade do Porto (FLUP), Investigador do ISUP, Presidente da Associação Portuguesa de Sociologia

Que a pandemia revelou a centralidade do conhecimento sociológico, parece ser hoje já um adquirido. Não apenas pela enorme necessidade que as pessoas sentem de incorporar conhecimento para, com isso, mudarem as suas práticas, ajustando-as às emergências sociais; não somente pela pertinência do vasto património sociológico acumulado sobre a aceleração do risco, da incerteza e das consequências não pretendidas da ação, em sociedades cada vez mais globalizadas e desreguladas, mas também pelo cariz revelador e multiplicador de velhas e novas desigualdades sociais que, mais do que tudo, tornam este vírus um fenómeno social. A des-naturalização da pandemia é um passo primeiro mas crucial para a sua compreensão e uma exigência para respostas integradas, inovadoras e não burocráticas.

No ensino superior, a emergência desocultou as desiguais condições de vida dos estudantes. Mostrou um território a várias velocidades, com um diverso acesso à banda larga ou a computadores devidamente apetrechados. Em temos de fetichismo e euforia tecnológica e de glorificação da "internet das coisas", importa ter em conta a internet das pessoas, isto é, o modo como a ela acedem e como dela se apropriam. No pico da pandemia, durante as minhas aulas via zoom, vários foram os estudantes que tinham de fazer escalas com os irmãos para o uso de computador ou que passavam tormentos pela debilidade da rede que teimava, paradoxalmente, em desconectá-los.

As aulas presenciais, nunca é de mais relembrá-lo, possuem, além do mais, uma singularidade insubstituível e radicam na articulação entre 
a linguagem das palavras e a linguagem dos comportamentos espacialmente situados. A aprendizagem necessita de uma forte componente de co-presença, mesmo em níveis avançados, como o ensino superior. $O$ cariz intersubjetivo da ação pedagógica assenta numa imbrincada combinação de palavra, gesto, mímica, dramatização, em que as performances corporais dos sujeitos educativos em situação desempenham um papel crucial na motivação, na expressão e na diversificação de estratégias comunicativas. Os estudantes das classes populares são quem mais pode beneficiar da atenção dada às múltiplas formas de expressão que não se limitam ao mundo das palavras e que penetram no que Edward T. Hall apelidou de "linguagem silenciosa", esse conjunto de finos e complicados "padrões de comportamento que determinam a gestão do tempo, as relações espaciais, as atitudes face ao trabalho, ao divertimento e à aprendizagem" (Hall, 1994: 11).

$\mathrm{Na}$ verdade, tudo depende, na relação pedagógica, da consciência sociológica do docente, do cardápio de possibilidades e instrumentos pedagógicos e da cultura institucional vigente. Mas o professor com consciência sociológica sabe como os mais desfavorecidos usam a complexidade linguística como recurso, se como tal for reconhecida e valorizada. O chão comum da aprendizagem vive de pormenores, de atenção às regiões que ligam diferentes apropriações do espaço (Goffman, 1993), de mediações, dos fios, mais frágeis ou mais vincados, que unem o quotidiano da vida em presença à rigidez das instituições e das estruturas sociais. Não raras vezes, nessas mediações, margens e interstícios, os estudantes menos capitalizados encontram guiões improvisados, informações preciosas, ainda que implícitas ou informais, pistas para a ação, ocasiões táticas de resistência e de afirmação. $\mathrm{Na}$ fantasmagoria virtual reifica-se a fala privilegiada do professor, o monopólio do uso da palavra e uma ordem do discurso tão artificial quanto linear e isenta de ruídos, imprevistos e conflitos. A aula, como treino de esfera pública, de escrutínio de argumentos e de confronto entre visões do mundo, sai irremediavelmente prejudicada.

Quero com estes argumentos salientar a especificidade distintiva do ensino presencial. Não ignoro, contudo, a importância de fatores que 
estão a montante e que, em intersecção, explicam as desigualdades no ensino superior (de acesso, de sucesso, de percurso): origens sociais, circuitos de escolarização anteriores, incorporação de hábitos de estudo; ordem familiar valorizadora (ou não) do trabalho escolar; redes de sociabilidade; pertença a associações, clubes, partidos, movimentos sociais; políticas educativas; sistemas de ação social; condições infraestruturais nos locais de ensino; etc. (Costa et al., 2014).

Em suma, os aspetos institucionais-organizacionais devem ser entendidos na articulação fecunda com dimensões contextuais macro-estruturais, mas também com os quadros de interação nos quais se desenrola a existência (e a agência, o projeto) estudantil.

O nível interacional de co-presença, aliado a uma consciência sociológica do professor (mesmo que não seja sociólogo, entenda-se) pode ajudar a fazer a diferença e insinua-se no efeito-escola, efeito-turma, efeito-professor. Na relação à distância mediada por computador, tal potencial desvitaliza-se significativamente.

Ainda assim, foi importante que as instituições de ensino superior tenham decidido, em resposta rápida e relativamente eficaz, manter uma rede de apoio aos estudantes consubstanciada, entre outros fatores, na manutenção da rotina das aulas, mesmo que virtuais. Essa decisão decerto impediu níveis superiores de anomia, de abandono e de insucesso. Contribuiu para manter laços e redes. Todavia, não glorifico essa solução de recurso, nem advogo a sua normalização. Ela deve ser, na minha opinião, um complemento subordinado à matriz do ensino presencial. Tal como o teletrabalho não constitui o Alfa e Ômega da reestruturação das organizações e relações laborais, também a crença voluntarista no ensino à distância traduz (trai?) uma nostalgia higienista de relações limpas do atrito e da sujidade da fricção, do contacto e da interação social. Entendamo-nos: sem ensino presencial perde-se a possibilidade de fazer universidade, nas hipóteses que apenas a sociabilidade promíscua permite - o jogo da alteridade, a impregnação do outro, a diversificação de repertórios, o laço, a ponte e a socialização do "estar junto" aqui e agora, nas múltiplas nuances de 
familiaridade e estranhamento, proximidade e distância, mesmidade e diferença.

Uma derradeira nota. Importará, no futuro, reforçar a formação pedagógica dos professores do ensino superior que, em geral, é insuficiente e autodidata. Hoje, mais do que nunca, a reflexão sobre a complexidade da relação pedagógica como relação de comunicação verbal e não verbal deveria ser objeto de um trabalho colaborativo e organizado, sem eclipsar as potencialidades que transporta.

Referências bibliográficas

Costa, António Firmino da; João Teixeira Lopes; e Ana Caetano (2014), Percursos de Estudantes no Ensino Superior. Fatores e processos de sucesso e insucesso, Lisboa, Mundos Sociais.

Goffman, Erving (1993), A Apresentação do Eu na Vida de Todos os Dias, Lisboa, Relógio d'Àgua.

Hall, Edward T. (1994), A Linguagem Silenciosa, Lisboa, Relógio d'Àgua. 
Entrevista realizada a João Teixeira Lopes no âmbito da rubrica "Um olhar sociológico sobre a crise Covid-19", publicada a 27 de abril de 2020.

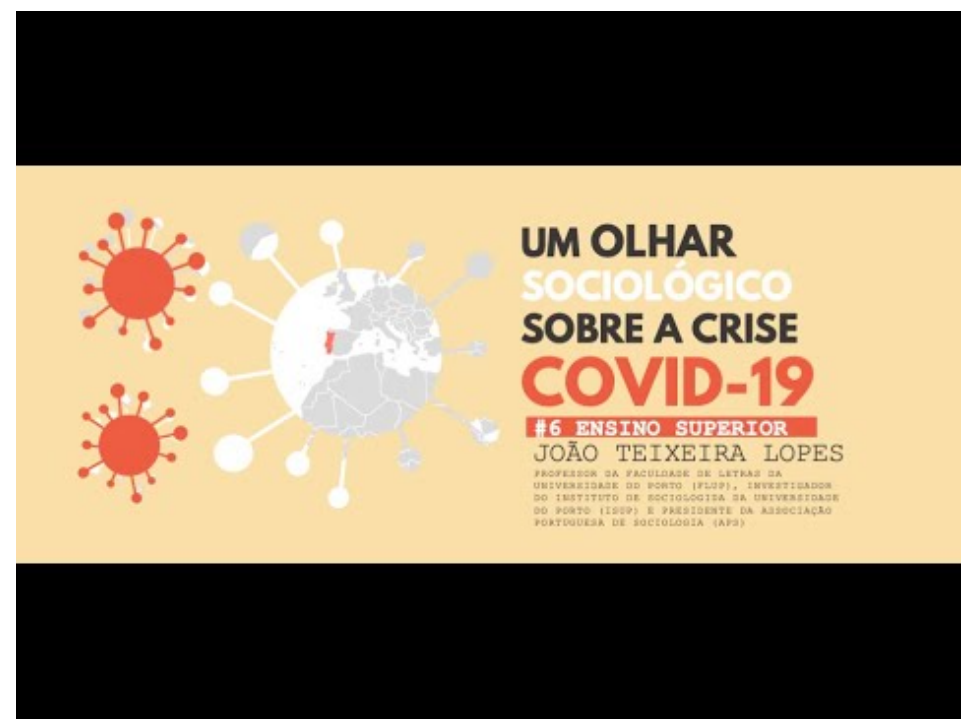




\section{CAPÍTULO 6 \\ O SECTOR ARTÍSTICO E CULTURAL, IMPACTOS E DESAFIOS DA CRISE PROVOCADA PELA COVID-19}

\section{José Soares Neves}

Investigador integrado e subdiretor do CIES-Iscte, Professor do Departamento de Sociologia no Iscte - Instituto Universitário de Lisboa, Diretor do Observatório Português das Atividades Culturais

A crise provocada pela Covid-19 teve forte impacto nos profissionais, nas organizações e nas instituições culturais e tornou mais visíveis os desafios que se colocam às políticas públicas, em particular, e de modo mais lato às relações entre sociedade e cultura, em inúmeras dimensões e cujo alcance ainda está longe de ser conhecido em toda a sua extensão. Neste texto avanço algumas pistas eventualmente úteis para a reflexão que os impactos e os desafios suscitam.

Começo por relembrar a complexidade do que designamos por cultura, e situo as fontes que nos permitem acompanhar as repercussões da crise, e as posições que têm vindo a suscitar. Abordo de seguida as respostas à crise pelas políticas públicas - e as questões associadas à sua eventual adequação e suficiência - para referir depois alguns efeitos que podemos antecipar no funcionamento dos mundos da arte e da cultura. Nesta sequência procuro identificar, com as incertezas que a crise ainda em evolução acarreta, possíveis medidas que importará equacionar no pós-crise. $E$, deste ponto de vista, também os desafios que se colocam no plano das desigualdades do acesso à cultura merecem particular destaque.

1. Com o eclodir da crise pela Covid-19 a cultura ganhou uma visibilidade acrescida, porventura mais alargada do que em momentos anteriores, destacando-se os efeitos negativos nos profissionais, nas organizações e no sector de um modo geral, e também a necessidade de medidas de diversa ordem, cultural, social, económica. Mas por isso 
mesmo talvez seja importante começar por relembrar a complexidade e as múltiplas dimensões em que é possível desdobrar o que designamos por cultura na contemporaneidade, mesmo considerando uma definição pragmática, ou seja, como uma das áreas governativas das políticas públicas (Santos et al., 1998). Desde logo pela diversidade de domínios que incluem as artes performativas, as artes visuais, o património (os monumentos e os museus, o património imaterial), os arquivos, as bibliotecas públicas, o livro e a imprensa, o audiovisual e o multimédia, diversidade que se alarga se tivermos em conta também as funções, desde a criação/produção à receção/consumo, passando pela mediação/distribuição (Bina et al., 2012).

Complexidade que ganha novos contornos consoante nos referimos ao sector cultural ou ao sector cultural e criativo (Quintela e Ferreira, 2018), ou ainda se tivermos em conta os sectores económicos em presença, ou seja, o sector público, o sector privado lucrativo e o sector privado não lucrativo ou terceiro sector (Gomes, Lourenço e Martinho, 2006). Ou se tivermos também em conta os géneros ou correntes artísticas, e respetivos cruzamentos, e as noções de cultura (popular, de massas, cultivada) (Santos, 2012). Ou ainda se tivermos presente a multiplicidade de agentes sociais envolvidos nos mundos da arte e da cultura, incluindo os criadores e todos aqueles que contribuem para que as obras e os eventos ocorram (Becker, 2010[1982]), e também os consumidores, os públicos (Crane, 1992: 112) e a diversidade de perfis profissionais, do estatuto de independentes, com vínculos precários, temporários ou parciais, aos trabalhadores por conta de outrem, com vínculos estáveis, permanentes.

Ou seja, as crises, agora em particular a crise devido à pandemia pela Covid-19 na cultura, fazem-se sentir em múltiplos planos, de modos variáveis e com efeitos igualmente diversos. Assim, falar da atual situação de crise na cultura significa ter em conta realidades e efeitos possivelmente muito diferentes.

$\mathrm{Na}$ fase inicial, as pistas disponíveis para analisar os impactos da Covid-19 na cultura estavam nas notícias e nas posições veiculadas no espaço mediático, nas redes sociais, nos sítios da internet, pelas 
organizações do sector e pelo governo, e depois nos resultados de inquéritos de organizações profissionais, nacionais e internacionais, e mais recentemente nos estudos promovidos por várias instituições e centros de investigação.

As posições e os inquéritos das organizações profissionais têm sido muito marcadas pela avaliação dos impactos económicos com vista a vincar a necessidade de respostas políticas, económicas e sociais, e sua urgência, e de exigir medidas especificas por parte dos governos para o respetivo domínio.

Em Portugal, várias organizações realizaram e divulgaram inquéritos aos seus associados, individuais e/ou coletivos, sobre os impactos da crise, de que são exemplo os promovidos pelo CENA-STE (três inquéritos realizados) ${ }^{1}$, pela GDA $^{2}$ e pelo ICOM-Portugal ${ }^{3}$. Entre os estudos realizados, menciono um de março de 2020 com base nas notícias de imprensa, posições de entidades públicas e privadas, legislação e orientações do Ministério da Cultura (Gama, 2020) e um outro de julho de 2020 com base nas respostas dos responsáveis por monumentos nacionais em Portugal sobre impactos durante o período do confinamento e medidas a adotar na sequência da crise (Neves et al., 2020).

No plano internacional, a situação devido à Covid-19, embora variando em escala, tem muitos pontos em comum: paragem precoce e generalizada das instituições e das atividades dominantemente presenciais (espetáculos, exposições, etc.), incerteza quanto a contratos e compromissos anteriormente firmados, estagnação das receitas, diminuição das procuras de trabalho, perda de rendimentos, incerteza quanto aos rendimentos no futuro imediato e à viabilidade da continuidade a prazo das atividades no sector das artes e da cultura por parte de organizações privadas e de profissionais independentes.

\footnotetext{
1 CENA-STE, ver aqui.

2 GDA, ver aqui.

3 ICOM-Pt, ver aqui.
} 
Neste plano, um dos estudos com um balanço mais abrangente é o da OCDE (Travkina e Sacco, 2020). Este e outros estudos entretanto realizados destacam os efeitos económicos, sociais e culturais nos profissionais independentes dos sectores criativo e cultural, com vínculos precários, uma categoria fortemente atingida devido à quebra de rendimentos, e na viabilidade económica destes sectores a curto prazo que a crise da Covid-19 veio evidenciar (Comunian e England, 2020: 118).

2. As medidas das políticas públicas de resposta à crise são várias, com diferentes alcances e que se vêm sucedendo, tal como aliás para outros sectores, procurando responder às situações que se vão revelando. Refletem de algum modo as articulações intergovernamentais de informação no plano da União Europeia. E aproximam-se das recomendações imanadas de instituições internacionais como a UNESCO, que preconiza medidas que fomentem a resiliência em três vertentes: apoios diretos a artistas e profissionais da cultura (benefícios sociais, aquisição de obras, compensação de quebras de rendimento e criação e oportunidades de formação com estágios remunerados), apoios às organizações dos sectores culturais e criativos (e.g. antecipando o pagamento de apoios, compensando perdas por quebras nas atividades) e orientadas para melhorar a competitividade das indústrias culturais e criativas (e.g. promovendo a realização de estudos e avaliações de modo a informar as medidas a adotar, promovendo os conteúdos nacionais) (UNESCO, 2020).

Nesse sentido são em geral adequadas, o que não significa que sejam suficientes. O balanço feito pela OCDE no já citado relatório sugere uma posição modesta de Portugal no conjunto das medidas políticas nas quatro vertentes consideradas: financiamento público, apoio ao emprego, adiamento de pagamentos e processos administrativos facilitados e políticas estruturais. Por exemplo, Portugal está ausente nas políticas estruturais, nas quais a OCDE considera a qualificação e criação de emprego de trabalhadores criativos, a 
mobilização de conhecimento e avaliação de impacto, a digitalização, entre outras (Travkina e Sacco, 2020: 53).

$\mathrm{Na}$ fase inicial, em Estado de Emergência, com a supressão dos eventos públicos e o encerramento ao público dos equipamentos culturais, logo a 14 de março, foram tomadas medidas dirigidas às organizações como a manutenção dos apoios financeiros às artes, assegurada a validade dos contratos de espetáculos e outras atividades artísticas e culturais já firmados por parte dos municípios, a regulação das entradas antecipadamente pagas pelos públicos para espetáculos. Após a reabertura ao público, existiram medidas de apoios à programação cultural, à adaptação dos espaços e equipamentos culturais independentes para corresponderem às medidas de saúde pública. E também medidas direcionadas às pessoas, designadamente de apoio social aos trabalhadores independentes. Algumas medidas abrangem todos os sectores (layoff e apoios aos trabalhadores independentes por parte da Segurança Social), outras são específicas da cultura, através do Ministério da Cultura, e foram fixadas no Programa de Estabilidade Económica e Social (Resolução do Conselho de Ministros $n^{\circ} 41 / 2020$, de 6 de junho). ${ }^{4}$

São respostas aos problemas que foram sendo identificados, com preocupação pelos mais vulneráveis, sobretudo os trabalhadores do sector privado, independentes, por conta própria, temporários ou parciais, com situações contratuais precárias (Carmo e Matias, 2019), situações comuns no sector da cultura, com uma incidência significativa de desproteção social.

Têm sido dadas várias respostas às questões económicas e sociais, designadamente a proteção dos rendimentos e a salvaguarda da capacidade criativa e de produção, procurando minimizar assim impactos imediatos e futuros, sociais e culturais; e a procura de agregar aos apoios públicos apoios privados. São medidas que, como antes referido, parecem ser em geral adequadas, embora não necessariamente suficientes - têm sido várias as manifestações por

\footnotetext{
${ }_{4}^{4}$ Programa de Estabilização Económica e Social, ver aqui.
} 
parte de trabalhadores do sector que destacam essa insuficiência - o que dependerá em grande medida da duração da crise de saúde pública.

Dependem também, nesse contexto, das soluções governativas de resposta às novas e antigas necessidades que se têm vindo a evidenciar na área da cultura e que vierem a ser implementadas, algumas das quais têm provocado algum debate, e expectativa, mais recentemente polarizado na proposta do Orçamento de Estado para 2021.5 Deste ponto de vista, uma medida em preparação que merece particular destaque é o "estatuto dos profissionais da cultura", de regulação do exercício da profissão e da proteção social, uma matéria que ganhou destaque no atual contexto, mas que decorre de diversas outras iniciativas governativas e alterações legislativas nas últimas duas décadas (Garcia et al., 2014: 46-48).

De todo o modo, tal como preconiza o relatório da UNESCO atrás citado, tanto a adequação como o alcance das medidas devem ser objeto de estudos de avaliação de modo a aferir com rigor o seu impacto e a informar as medidas a adotar na fase pós-crise.

3. $\bigcirc$ funcionamento dos mundos da arte e da cultura terá seguramente mudanças decorrentes da experiência da atual crise. Uma delas tem que ver com a maior importância do digital nos vários domínios artísticos e culturais. Não tanto do ponto de vista da criação - os criadores e produtores têm uma utilização intensiva de novas tecnologias - mas sobretudo na mediação, na receção e no consumo.

Destaco aqui as questões do consumo. Por um lado, estamos com possibilidades de acesso acrescidas aos conteúdos online por parte das organizações e dos criadores e artistas, o que permitiu evidenciar a importância da cultura, mas também a fragilidade da economia cultural (Banks, 2020), sendo que um problema que se coloca aqui é a remuneração do trabalho artístico e cultural de modo a assegurar a sua sustentação que garante a continuidade da criação (Becker, 2010[1982]).

\footnotetext{
5 Ver aqui.
} 
Este aspeto é talvez mais notório no domínio das artes do espetáculo, mas aplica-se aos vários domínios, e em particular aos projetos emergentes e a artistas mais jovens, uma vez que em situações de crise as apostas dos apoios privados (e das audiências) se dirigem sobretudo para projetos e artistas consagrados (Bonet e Donato, 2011).

Por outro lado, enfrentamos sérias restrições quanto aos espetáculos ao vivo e outros eventos eminentemente presenciais, como os festivais e as festas populares, de efervescência coletiva (Santos e Costa et al., 1999) que caracterizam muitos dos eventos culturais, em particular na música popular.

Assim, na perspetiva dos eventos para grupos, coletivos de indivíduos, são mais notórios os efeitos de limitação e de retração das ofertas e das procuras, eventualmente menos sentidos na cultura cultivada, normalmente mais contidos em termos de quantidade e de proximidade física dos participantes.

Do ponto de vista dos pequenos grupos, das famílias, dos indivíduos, é expectável a emergência de novas dietas de consumo cultural, com recuo das práticas de saída face às domésticas - aliás já dominantes, se pensarmos desde logo na televisão, como mostram os estudos disponíveis sobre participação cultural, mas agora com o acréscimo dos consumos via online.

Todos estes fatores sugerem também mudanças nas relações de sociabilidade inerentes à participação em eventos culturais (Lopes, 1998: 200; Mantecón, 2009), propensos que são a contextos sociais deste tipo, muitas vezes motivos para saídas em família, em grupos mais ou menos alargados, para encontros de amigos e conhecidos.

Sugerem ainda mudanças no funcionamento das instituições culturais com serviços para os públicos, sobretudo nas mais procuradas pelo turismo - genericamente as instituições do património cultural, os monumentos, os museus - devido às fortes quebras de receitas e à necessidade de adequação ao menor número de visitantes, de novo maioritariamente nacionais (Neves et al., 2020). E também nas organizações e nas empresas de concertos/festivais de verão, ao ar livre, 
em especial de música e de pop/rock, que vinham registando níveis crescentes de adesão (Neves e Miranda, 2020).

4. Será talvez cedo para antecipar as políticas a implementar depois desta crise, uma vez que não é ainda nítido como iremos emergir dela. Em todo o caso, estão a ser pensadas várias linhas (que eu diria) estratégicas, para o médio prazo, no horizonte 2030, como por exemplo no domínio dos museus (Camacho, 2020), mas também nos equipamentos culturais (vide Rede Portuguesa de Teatros e Cineteatros), no apoio financeiro às artes, no cinema, entre outros.

Ainda assim, destaco quatro linhas de política pública que será importante implementar, acompanhar... e avaliar no sentido da melhoria do cumprimento dos seus objetivos. Desde logo, as questões do estatuto do profissional da cultura, das condições laborais e da proteção social dos trabalhadores independentes. Para além da importância da manutenção (e eventual alargamento) dos apoios financeiros às entidades privadas, coloca-se também a necessidade urgente de dotar os serviços públicos dos recursos (humanos e financeiros) necessários para enfrentar os (velhos e) novos desafios que se colocam, e que se adivinham, para assegurar e melhorar a prestação dos serviços que constam das suas missões.

Uma terceira linha de incentivo prende-se com a participação cultural por parte da população, de formação de públicos, mas também de uma forma mais direta, neste contexto, de (re)criação de mercados culturais. Vale a pena lembrar que Portugal tinha, antes da presente crise, um dos mais baixos níveis de práticas culturais da população entre os países da União Europeia, posição que aliás se agravou em virtude da anterior crise económica e financeira (Eurobarómetro, 2013). Haverá novo agravamento? Possivelmente sim, há que estudar e tomar medidas de acordo com as conclusões obtidas.

Uma quarta tem que ver com a produção de conhecimento nesta área. Como investigador, parece-me importante destacar a necessidade de melhorar o conhecimento científico sobre o sector da cultura, dada a escassez de estudos e de linhas de pesquisa capazes de iluminar as suas 
diversas componentes, na dupla perspetiva da atualidade como das evoluções registadas, de informar o desenho, a implementação e a avaliação de medidas e políticas.

Por exemplo, sabemos pouco sobre a evolução dos níveis de participação cultural dos portugueses e do impacto das várias conjunturas (favoráveis ou desfavoráveis, como a atual). Não temos uma linha de inquérito longitudinal às práticas culturais da população. Essa é uma das vertentes. A outra é que também sabemos muito pouco sobre o conjunto dos equipamentos, das entidades e dos agentes artísticos e culturais, dos criadores aos técnicos, os intérpretes, passando pelos mediadores, ou seja, dos intervenientes nos mundos da arte. Deste ponto de vista, o trabalho independente é paradigmático.

Acompanhando as preocupações de informação por conhecimento científico das medidas de políticas públicas na área da saúde, por esta altura muito destacadas, penso ser importante deixar também uma chamada de atenção para que essa necessidade se faz sentir também na área da cultura (Neves, no prelo). 6

5. Do ponto de vista das desigualdades, e em particular das desigualdades sociais no acesso à cultura (e, na perspetiva da democratização, em especial à cultura cultivada), um ponto de grande relevância refere-se ao impacto na qualificação da população. A escolaridade, é sabido, é o principal fator de desigualdades sociais no acesso à cultura (Bourdieu e Darbel, 1966), sendo um fator particularmente importante em Portugal na atualidade, diretamente relacionado com os relativamente baixos níveis de escolaridade da população (Neves, 2015; Neves e Gomes, 2018). Desse ponto de vista, talvez o aspeto mais importante é que a recuperação que se vinha dando nos últimos anos, com níveis de qualificação mais elevados da

\footnotetext{
6 A este propósito destaco, entre outras eventuais iniciativas do Ministério da Cultura direcionadas para a investigação, o Estudo Sector Artístico em Portugal, lançado em fins de julho de 2020, uma parceria institucional da DGARTES com o ISCTE-IUL, a cargo do Observatório Português das Atividades Culturais.
} 
população portuguesa, e também associado a maiores níveis de proximidade com a cultura, se mantenha. Não é certo. Digamos que a questão central aqui é talvez esta: em que medida é que a crise económica associada à crise da Covid-19 se refletirá na educação, na frequência do sistema de ensino e, por essa via, no acesso e na participação cultural?

Por outro lado, porventura num sentido mais positivo, são de assinalar as competências digitais melhoradas, mais desenvolvidas pelas exigências escolares e profissionais (próprias e dos filhos) devido ao trabalho/estudo à distância, por aqueles que tiveram acesso aos conteúdos por disporem dos equipamentos adequados, importa ressalvar. E sabemos que isso não se tem revelado fácil para uma parte importante das famílias, em que as questões de concorrência de equipamentos para dar sequência às várias necessidades e aos vários usos requeridos - culturais, profissionais, de ensino - se têm revelado algo difíceis.

Portanto constatam-se impactos diferentes, por um lado de melhoria, por outro de dificuldades acrescidas, o que quer dizer também acréscimo de desigualdades. Ou seja, desigualdades pelo acesso aos equipamentos, com reflexos a vários níveis, para além dos que advêm dos diferentes níveis de literacia digital. E, noutro plano, desigualdades que se podem adivinhar devido às exigências de distância social, ou melhor, física, e suas implicações nas ofertas em eventos presenciais, na sua disseminação no território nacional e de que forma é que isso pode levar ao agravamento das desigualdades territoriais no acesso à cultura.

\section{Notas finais}

A crise pela Covid-19 teve inúmeros impactos e veio acrescentar mais desafios - uns novos, outros que decorrem de problemas que já anteriormente se manifestavam - ao sector da cultura. Procurei neste texto referir alguns aspetos porventura úteis para refletir o contexto atual e outros que dele decorrem para o período pós-crise Covid-19. 
Em síntese, defendi que essa reflexão deverá ter em conta a diversidade do que designamos por sector cultural nas suas múltiplas dimensões, umas mais expostas aos efeitos imediatos da crise (parte importante dos profissionais independentes, com vínculos laborais precários, de todos os domínios e funções, pela perda de rendimentos e fragilidade em termos de proteção social), outras menos, mas que de uma forma ou de outra serão afetadas. O contexto de crise veio trazer nova visibilidade ao sector da cultura no espaço mediatário e digital, online, pela exposição do contexto cultural (cancelamento de eventos, encerramento de instituições, diminuição dos públicos, agora quase exclusivamente nacionais) económicos e sociais (perda de rendimentos, fragilidade ou ausência de proteção social). Motivou também novos estudos e relatórios nacionais e internacionais que permitiram enquadrar o caso português no plano internacional, não só quanto aos efeitos como também quanto às medidas políticas de resposta à crise.

Deste ponto de vista, as respostas têm sido genericamente adequadas, o que não significa necessariamente suficientes. Decorreram num contexto de urgência, têm enquadramento no plano internacional, mas, também neste plano, mostram ainda diversas fragilidades, por exemplo nas medidas estruturais de preparação da fase pós-Covid-19.

E estas medidas serão fundamentais para dar continuidade, sem quebras acentuadas e com maior consistência, ao funcionamento dos mundos da arte e da cultura, que encontram talvez, no desenvolvimento do digital, online, uma das principais mudanças, em particular na mediação e no consumo. Outra mudança situa-se na ausência, ou mitigação, das relações de sociabilidade inerentes à participação (como públicos ou outras) em eventos culturais presenciais.

Entre as medidas a adotar estão as que visam promover justamente a participação cultural - em certa medida a revitalização do mercado cultural - e as que possibilitarão a realização de estudos que contribuam para conhecer melhor a realidade portuguesa e informar o desenho, acompanhamento e avaliação das políticas culturais. 
Por último, importa ter em atenção os impactos da pandemia na qualificação dos portugueses, no sentido em que a escolaridade é um dos principais fatores de desigualdades sociais no acesso à cultura. Num outro prisma, importa também estudar como irão evoluir a posse de equipamentos e as competências (literacia) digitais, em princípio uma das dimensões com impacto positivo. Finalmente, penso ser importante procurar entender os eventuais impactos da Covid-19 nas desigualdades do acesso à cultura numa perspetiva territorial.

\section{Referências bibliográficas}

Banks, Mark (2020), "The work of culture and C-19", European Journal of Cultural Studies, 23(4), pp. $648-654$.

Becker, Howard S. (2010[1982]), Mundos da Arte, Lisboa, Livros Horizonte.

Bina, Vladimir; Philippe Chantepie; Valérie Deroin; Guy Frank; Kutt Kommel; Josef Kotynek; e Philippe Robin (2012), ESSnet-Culture Final Report, Luxemburgo, ESSnet Culture e Eurostat.

Bonet, Lluís; e Fabio Donato (2011), "The Financial Crisis and its Impact on the Current Models of Governance and Management of the Cultural Sector in Europe", ENCACT Journal of Cultural Management and Policy, 1(1), pp. 4-11.

Bourdieu, Pierre; e Alain Darbel (1966), L'Amour de L'Art: Les Musées et Leur Public, Paris, Les Éditions de Minuit.

Camacho, Clara Frayão (coord.) (2020), Grupo de Projeto Museus no Futuro. Relatório Final.

Carmo, Renato Miguel do; e Ana Rita Matias (2019), Retratos da Precariedade, Lisboa, Tinta da China.

Comunian, Roberta; e Lauren England (2020), "Creative and cultural work without filters: Covid-19 and exposed precarity in the creative economy", Cultural Trends, 29(2), pp. 112-128.

Crane, Diana (1992), The Production of Culture. Media and the Urban Arts, Newbury Park, Londres e Nova Deli, Sage. 
Eurobarómetro (2013), Cultural Access and Participation. Special Eurobarometer 399, Bruxelas, Comissão Europeia.

Gama, Manuel (coord.) (2020), Impactos da COVID-19 no setor cultural português: Resultados preliminares de março de 2020 Working report POLObs \#1, CECS-POLOBS.

Garcia, José Luís; João Teixeira Lopes; José Soares Neves; Rui Telmo Gomes; Teresa Duarte Martinho; e Vera Borges (coord.) (2014), Mapear os Recursos, Levantamento da Legislação, Caracterização dos Atores, Comparação Internacional, Lisboa, SEC/GEPAC.

Gomes, Rui Telmo; Vanda Lourenço; e Teresa Duarte Martinho (2006), Entidades Culturais e Artísticas em Portugal, Lisboa, OAC.

Lopes, João Teixeira (1998), "Sociabilidade e consumos culturais: contributos para uma sociologia da fruição cultural ", Sociologia, l(8), pp. 179-188.

Mantecón, Ana Rosas (2009), "O que é o público?", Poiésis, 14, pp. 175-215.

Neves, José Soares (2015), "Práticas culturais e desigualdades na Europa" em Carmo, Renato Miguel do e António Firmino da Costa (Orgs.), Desigualdades em Questão: Análises e Problemáticas, Lisboa, Mundos Sociais, pp. 31-41.

Neves, José Soares (no prelo), "Políticas culturais e infraestruturas de pesquisa: o caso português".

Neves, José Soares (coord.); Sofia Costa Macedo; Maria João Lima; Jorge Santos; e Ana Paula Miranda (2020), Os Monumentos Nacionais de Portugal e a Abertura ao Público. Impactos decorrente da COVID-19, Lisboa, Observatório Português das Atividades Culturais, CIES, ISCTE-IUL.

Neves, José Soares; e Rui Telmo Gomes (2018), "Práticas culturais e acesso à cultura" em Carmo, Renato Miguel do; João Sebastião; Joana Azevedo; Susana da Cruz Martins; e António Firmino da Costa, Desigualdades Sociais: Portugal e a Europa, Lisboa, Mundos Sociais, pp. 41-52.

Neves, José Soares; e Ana Paula Miranda (2020), Concertos de música em Portugal, Lisboa, OPAC-Observatório Português das Atividades Culturais, CIES, ISCTE-IUL. 
Quintela, Pedro; e Claudino Ferreira (2018), "Indústrias culturais e criativas em Portugal: Um balanço crítico de uma nova 'agenda' para as políticas públicas no início deste milénio", Revista Todas as Artes, 1(1), pp. 88-110.

Santos, Maria de Lourdes Lima dos (2012), Sociologia da Cultura. Perfil de Uma Carreira, Lisboa, ICS.

Santos, Maria de Lourdes Lima dos (coord.), et al., (1998), As Políticas Culturais em Portugal, Lisboa, OAC.

Santos, Maria de Lourdes Lima dos; e António Firmino da Costa (coords.), Rui Telmo Gomes; Vanda Lourenço; Teresa Duarte Martinho; José Soares Neves; e ldalina Conde (1999), Impactos Culturais da Expo'98, Lisboa, OAC.

Travkina, Ekatarina; e Pier Luigi Sacco (2020), Culture shock: COVID-19 and the cultural and creative sectors, OCDE.

UNESCO (2020), Culture in Crisis. Policy guide for a resilient creactive sector, Paris, UNESCO. 
Entrevista realizada a José Soares Neves no âmbito da rubrica "Um olhar sociológico sobre a crise Covid-19", publicada a 13 de abril de 2020.

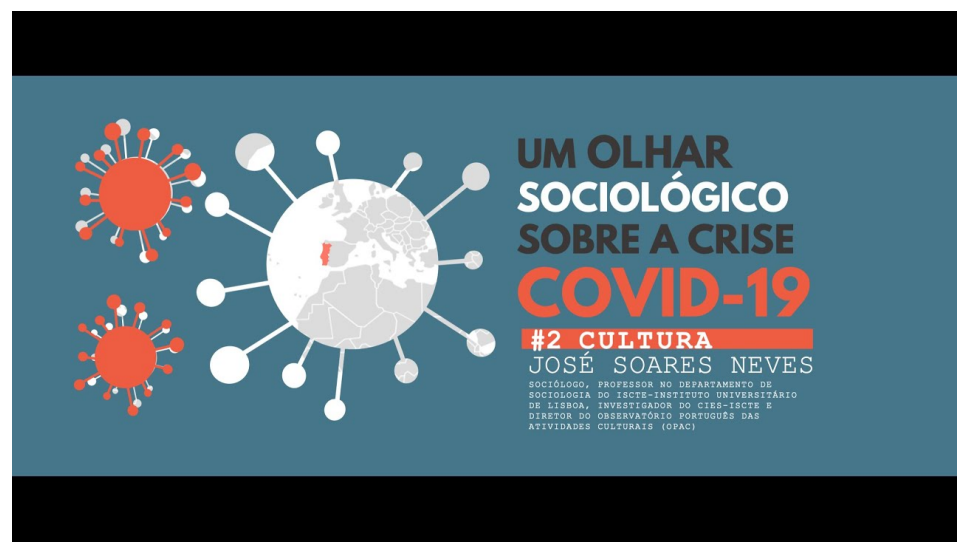




\section{CAPÍTULO 7 \\ HABITAÇÃO, PANDEMIA, CRISE}

\section{Ana Drago \\ Socióloga, Investigadora do Centro de Estudos Sociais em Lisboa}

Nos primeiros dias do confinamento, a habitação emergiu como decisiva no combate à nova pandemia da Covid-19. Um pouco por todo o mundo, governos, especialistas e autoridades de saúde apontaram a importância de todos "ficarem em casa"; na imprensa e nas redes sociais, figuras públicas multiplicaram-se nesse apelo; e nós próprios repetimos o mote nas conversas angustiadas com familiares e amigos. A casa - a habitação - tornou-se, assim, o mais eficaz instrumento de contenção da propagação da pandemia e, nos meses em que "ficámos em casa", o espaço doméstico reinventou-se para milhões de pessoas como local de trabalho ou sala de aula, ginásio ou oficina.

As diferenças nas formas de habitar e as várias geografias sociais que as compõem revelaram-se marcantes nessa vivência do confinamento - a diversidade de estruturas urbanas, as portentosas densidades populacionais das grandes metrópoles, o próprio espaço disponível das habitações fizeram com que esse período de reclusão doméstica fosse vivido de forma muito diferente pelos vários segmentos sociais. E, porque sabemos que a desigualdade social conta sempre, não só a comodidade oferecida pelas habitações como as diferentes possibilidades de fazer face aos custos da habitação, num momento em que a economia (quase) parava, pesaram igualmente no modo como diversos grupos sociais experienciaram o longo confinamento.

Neste texto propomo-nos a refletir sobre os impactos da pandemia no campo da habitação, procurando dar conta quer dos seus efeitos mais imediatos, quer de outros que se perspetivam, por agora, ainda meio adivinhados. Como noutros domínios da vida social, no campo da 
habitação cruzam-se diferentes dimensões políticas, sociais e económicas. A habitação é a casa no sentido afetivo de lar - isto é, espaço da domesticidade, da família, de descanso e de convívio. Mas em torno da casa cruzam-se igualmente outras dimensões - o emprego e a economia; a localização no território, e as oportunidades e os constrangimentos que essa localização implica; as disparidades de rendimentos e a origem social. A habitação é, portanto, mais que "casa" - é mercado, rendimento e/ou dívida; é um campo onde se inscrevem lógicas de reprodução de desigualdades estruturais; e, nas nossas economias financeirizadas, a habitação tem vindo igualmente a tornar-se num dos objetos primordiais de investimento e rentabilidade, ligando o sistema bancário, diferentes agentes económicos e as próprias estratégias de investimento e poupança dos agregados familiares.

Em Portugal, as desigualdades no campo da habitação contaram certamente no momento em que chegou a pandemia. Apesar de consagrada como direito da cidadania democrática, a habitação tendeu a permanecer na história da democracia portuguesa como uma dimensão de reprodução das desigualdades sociais. Como vários investigadores têm repetidamente demonstrado, as políticas de habitação nunca escaparam a um estatuto de relativa menoridade no conjunto das políticas sociais que procuraram dar corpo aos direitos sociais da democracia (Rodrigues et al., 2016; Serra, 2019). Assim, ao longo das últimas décadas e pela mão de diversos governos, os gastos públicos no sector foram sempre muito reduzidos; a provisão pública de resposta habitacional foi parca; e desde cedo que no quadro democrático prevaleceu uma orientação política que responsabilizou as famílias pelo financiamento da habitação, incentivando o endividamento para compra de casa própria. Na exata medida em que, em Portugal, a habitação foi sempre mais mercado do que direito social, a desigualdade que permeou o acesso à habitação em Portugal implicou que, no contexto pandémico, não só tivéssemos largos segmentos sociais para quem o confinamento exigiu um esforço acrescido, como tudo indica será sobre esses segmentos socialmente 
mais frágeis que a crise económica que se anuncia para os próximos tempos trará dificuldades no domínio da habitação.

Sem pretensão de esgotar o tema, procuramos nas próximas páginas fazer uma reflexão tendo como foco principal a questão da habitação na sociedade portuguesa face a estes tempos de incerteza. Organizamos essa reflexão em dois passos. Num primeiro momento, procuramos convocar alguns indicadores que nos permitem ler o modo como o confinamento foi vivido por diferentes segmentos sociais e como a configuração desigual do campo da habitação foi lida e respondida pelas medidas postas em marcha pelo governo a partir de março de 2020. Num segundo momento, lançando mão de uma abordagem assumidamente mais prospetiva, argumentamos que os efeitos da crise pandémica na economia portuguesa apontam para o risco de vivermos um agravamento significativo das desigualdades na habitação em Portugal. Na verdade, se não contarmos com políticas públicas fortes, há indícios de que assistiremos ao acentuar de uma dualização social em torno da capacidade de suportar o acesso a uma habitação adequada por parte de largos estratos sociais. Assim, tudo parece apontar para que a questão dos custos da habitação se colocará como um marcador relevante das desigualdades sociais, reproduzindo e cimentando no campo da habitação outras desigualdades que se desenham ao nível do rendimento e nas formas de inserção no mercado de trabalho. Face à pandemia e no campo da habitação, encontraremos de um lado um grupo composto pelos proprietários de casa própria que têm a sua hipoteca já saldada ou que beneficiam de prestações pouco significativas em relação aos seus rendimentos, que têm emprego estável e/ou pouco afetado pela contração económica - para este grupo a habitação não era e não será um problema e, em determinados casos, pode até ser uma fonte de rendimento. Mas, do outro lado, encontraremos ocupantes proprietários fortemente endividados e com elevadas prestações; arrendatários nas grandes áreas metropolitanas com custos elevados; e segmentos de trabalhadores que, com a retração da atividade económica, correm o risco de perda de emprego e/ou forte redução de rendimentos. Para 
este segundo grupo, a habitação pode tornar-se uma dimensão grave de privação.

A desigualdade habitacional quando a casa foi a primeira "vacina" disponível

Talvez o momento em que no contexto da pandemia a relação entre habitação, rendimento e inserção no mercado de trabalho assumiu uma maior clareza na sociedade portuguesa foi aquando da definição de medidas especiais de confinamento para 19 freguesias das periferias suburbanas da Área Metropolitana de Lisboa (AML). Os dados então coletados pelo INE (2020) apontavam a relevância da espacialização das desigualdades na estrutura urbana e nas características habitacionais. Era nestas freguesias suburbanas que se concentravam grandes densidades populacionais e espaços domésticos mais exíguos e, tudo apontava, era também aqui que se agregavam segmentos da população com modelos de inserção no mercado de trabalho que não Ihes permitiam o recurso ao teletrabalho; nem dispunham de rendimentos que thes permitissem acolher perdas salariais significativas. Seguindo o que víamos noutros contextos pelo mundo fora - talvez de forma quase cristalina em Nova lorque onde, num espaço de hiperdensidade habitacional, as comunidades mais pobres foram assimetricamente castigadas pelo contágio - também em Portugal a desigualdade no trabalho e na habitação tinha óbvios efeitos epidemiológicos.

Assim, a reflexão sobre os efeitos da pandemia no campo da habitação deve ter em conta duas dimensões: por um lado, as condições de habitabilidade que condicionaram a forma como diferentes agregados experienciaram o confinamento; e, por outro lado, a capacidade financeira de fazer face aos custos da habitação.

A primeira dimensão pede que olhemos com atenção alguns traços que caracterizam as condições de habitação em Portugal. Os dados que conhecemos mostram como o esforço de "ficar em casa" foi significativo para largas camadas - destacamos aqui três traços. Em 
primeiro lugar, e embora já longe dos tempos dos extensos bairros de lata que rodeavam os grandes centros urbanos até meados dos anos 90, Portugal acolhe ainda hoje um conjunto significativo de agregados familiares que vivem em habitações precárias ou profundamente degradadas que implicam a necessidade de realojamento. Em 2018, o Instituto da Habitação e da Reabilitação Urbana (IHRU) estimava que quase 26 mil famílias vivessem em situação de carência habitacional grave (IHRU, 2018: 3). Vale a pena sublinhar que essas necessidades de realojamento se situam maioritariamente nas áreas metropolitanas - é, portanto, nas principais cidades que a habitação permanece como um desafio político. Em segundo lugar, Portugal surge marcado por níveis relevantes de privação habitacional. Cerca de um terço dos portugueses experienciam algum tipo de privação habitacional, e são significativos os problemas na qualidade das habitações - humidades, tetos ou paredes degradadas, etc. - indicando fraca qualidade construtiva, mas também a incapacidade financeira de muitos agregados em solucionar estes problemas. E, em terceiro lugar, a sociedade portuguesa continua a exibir taxas relevantes de sobreocupação habitacional: 9,5\%, quase o dobro do valor da vizinha Espanha. Aliás, contrariando a descida da sobreocupação habitacional, Portugal registou, já após a crise de 2011-2013, um retomar do aumento da sobrelotação nos territórios suburbanos e nas cidades médias. ${ }^{2}$ Tudo indica que, já antes da pandemia, o acesso à habitação se estava a tornar um problema para as camadas populares dos territórios suburbanos.

A segunda dimensão a ter em conta prende-se com os encargos das famílias portuguesas com a sua habitação face à contração económica vivida no confinamento, e das consequências desta nova crise no emprego e nos rendimentos dos trabalhadores. Os dados disponíveis indicam que uma franca dose de inquietação é aconselhável. Na sequência do chamado "período da troika", Portugal viveu uma subida

\footnotetext{
1 Fonte: Eurostat: [ilc_lvho05a]. Ver aqui.

2 Fonte: Eurostat: [ilc_Ivho05d]. Ver aqui.
} 
vertiginosa dos preços na habitação, ${ }^{3}$ que se iniciou nos territórios mais afluentes das áreas metropolitanas e se propagou pelas periferias urbanas. Com essa escalada nos preços, os custos de habitação têm vindo a subir para alguns segmentos sociais: camadas jovens e trabalhadores precários que adquiriram casa nos últimos anos com hipotecas onerosas; e arrendatários nos grandes centros urbanos, onde as rendas subiram exponencialmente após a liberalização do arrendamento urbano de 2012. Os indicadores disponíveis indiciam que as despesas habitacionais têm aumentado o seu peso nos orçamentos familiares e, no caso do arrendamento, os valores de sobrecarga de despesas com habitação eram, em 2019, superiores aos valores anteriores à crise de 2011-2013. Mais de um quarto dos arrendatários $26,3 \%$ - não protegidos pelo controlo de rendas vive sobrecarregado com os custos da sua habitação. ${ }^{4} \mathrm{E}$ é sobre os mais pobres que esse peso da habitação já era significativo - cerca de $20 \%$ dos agregados familiares do primeiro quintil de rendimentos viviam já sobrecarregados com custos habitacionais, um valor que é quatro vezes superior ao segundo quintil e dez vezes o valor relativo ao terceiro quintil de rendimentos. ${ }^{5}$

Estranhamente, aquando da declaração inicial de Estado de Emergência em Portugal, em março de 2020, os pagamentos relativos à habitação não foram identificados como colocando um problema no primeiro pacote de medidas governamentais apresentadas como necessárias para sustentar os rendimentos e necessidades das famílias. À época, o Primeiro-ministro argumentava que os instrumentos de substituição dos rendimentos do trabalho permitiriam manter esses pagamentos. Contudo, e à semelhança de muitos países europeus e nos EUA, em Portugal foram estabelecidos programas de empréstimo para os arrendamentos, moratórias nos pagamentos do crédito à

\footnotetext{
${ }^{3}$ Fonte: Eurostat: [prc_hpi_a]. Ver aqui.

${ }^{4}$ Fonte: Eurostat: [ilc_lvho07c]. Ver aqui.

${ }^{5}$ Fonte: Eurostat: [ilc_lvps08]. Ver aqui.
} 
habitação e foram proibidos os despejos. Meses depois, em meados de setembro, era noticiado que haviam sido feitos cerca de 2.100 pedidos de empréstimos ao IHRU ao abrigo deste programa de apoio ao arrendamento, um valor muito reduzido no universo de contratos de arrendamento, o que parece indicar que muitos inquilinos atingidos pela quebra de rendimentos terão conseguido negociar reduções nos pagamentos com os seus senhorios. Contudo, é de prever que esses acordos informais não durarão o tempo longo da crise que se anuncia e, embora o fim da proibição de despejos se deva prolongar até final de 2020, a provável duração da crise pelo próximo ano adentro coloca o risco de perda de habitação de contingentes significativos de arrendatários. Já no que toca às moratórias no pagamento das hipotecas de crédito à habitação, o Banco de Portugal divulgava antes do verão que estavam em vigor cerca de 322 mil moratórias relativas a crédito à habitação ou outros créditos hipotecários. Estas moratórias podem vigorar até final de março de 2021,6 mas também aqui se coloca a questão do prolongamento da crise económica.

Assim, dada a dificuldade de recuperação da atividade económica, a questão dos pagamentos na habitação deverá manter-se num horizonte temporal que irá bem além do primeiro trimestre de 2021. Os riscos de uma onda generalizada de despejos não foram, portanto, totalmente eliminados e têm vindo, aliás, a ser discutidos em vários países: pelos riscos epidemiológicos que obviamente colocam, mas também pela possibilidade de assistirmos a um (novo) colapso do mercado habitacional. E, como aprendemos em 2008, quando o mercado habitacional cai, arrasta consigo a economia.

6 Fonte: Banco de Portugal, COVID-19. Evolução das moratórias de crédito, 30 de junho de 2020. 
Em busca do futuro: cidade e contágio, apocalipse e utopia

Fechados em casa na primavera de 2020, foram chegando até nós as imagens distópicas de grandes cidades históricas como Paris, Roma, Nova lorque ou Lisboa esvaziadas de gente, agitação, convívio ou comércio. O futuro das grandes agregações urbanas parecia vacilar. As densidades habitacionais metropolitanas pareciam agora ameaçadoras e os contactos inevitáveis nesses espaços centrais deveriam ser repensados nos próximos tempos. A cidade enquanto espaço de vivências partilhadas surgia agora tingida de laivos de ameaça e risco.

Por esses dias, surgiram propostas que se debruçavam sobre o futuro da cidade e da habitação, retomando aliás uma prática de pensamento utópico e futurista que sempre animou os debates dos estudos urbanos e da arquitetura. Quase repegando a preocupação que a tradição higienista assumiu a partir do século XIX, à época em torno da salubridade das habitações e dos contágios noutros surtos virais, pretendia-se agora pensar como seguir a vida num mundo cada vez mais urbano em tempos de nova pandemia.

Nesses debates, surgiam vozes que apontavam as possibilidades demonstradas pelo teletrabalho - as grandes agregações humanas podiam ser desdensificadas pela inscrição do trabalho no espaço doméstico: trabalharíamos e viveríamos mais distantes uns dos outros. Apontava-se a "grande migração de 2020", como the chamou o Washington Post ${ }^{7}$ - fosse a experiência daqueles que fizeram uso das suas casas de férias em modelos confortáveis e afluentes de exurbia para viver o confinamento e trabalhar online na sala de estar; ou de muitos outros, estudantes ou trabalhadores precários dos sectores que pararam nos espaços metropolitanos, e que nesses meses rumaram à casa familiar de origem em territórios menos urbanos. Se o contágio permanecesse como risco e medo social, e o contacto social se mantivessem em suspenso por um tempo significativo, poderíamos

7 The Great American Migration of 2020: On the move to escape the coronavirus", Washington Post, 28 de março de 2020. 
eventualmente discutir a hipótese de caminharmos nos próximos anos para um movimento de desurbanização.

Noutras paragens, discutiu-se a necessidade de reinventar as formas de viver a cidade e a metrópole, sem desistir das concentrações habitacionais. Em meados de julho de 2020, o Financial Times divulgava as propostas de urbanistas que apontavam a necessidade de desafiar uma tradição de zonamento urbano organizado em torno de lógicas monofuncionais que separavam bairros e zonas, e que desenhavam a hierarquização centro/periferia das grandes metrópoles. Esse tempo da cidade-metrópole organizada em anéis concêntricos que partiam dos centros financeiros e zonas comerciais e/ou escritórios, rodeadas de vastas zonas suburbanas residenciais ou periferias industriais (as que restam) teria agora chegado ao fim. Retomando debates antigos, fez-se a defesa de espaços urbanos que agregassem a residência, o trabalho, o comércio e os serviços em distâncias curtas. Ou seja, desenhar unidades de organização urbana que colocassem "tudo" o que é necessário à vida comunitária contemporânea numa lógica de proximidade pedonal ou ciclável: a chamada 15 minute city. ${ }^{8}$

$\bigcirc$ pensamento especulativo é central nos momentos de crise: é assim que experimentamos possibilidades, avaliamos riscos e apontamos incertezas. Contudo, talvez algum ceticismo seja, de momento, aconselhável. Mudanças muito bruscas não parecem colocarse no horizonte - pelo menos por agora. $\bigcirc$ que parece estar em causa no campo da habitação é antes a aferição dos efeitos sociais e políticos que a brutal crise económica que iremos enfrentar, pelo menos no próximo ano, terá no campo da habitação.

Essa reflexão prospetiva sobre esses efeitos tem necessariamente de partir de inquietações que, na verdade, estavam já presentes nos nossos debates ainda antes de nos terem pedido para ficarmos em casa. Como dissemos, a habitação é casa, mercado, rendimento e, ao longo das últimas três décadas, tornou-se igualmente um veículo primordial de inscrição dos processos de financeirização nas sociedades

\footnotetext{
8 "Welcome to the 15-minute city", Financial Times, 17 de julho de 2020.
} 
da atualidade. Em Portugal, essa centralidade da relação entre habitação, financeirização e economia metropolitana é particularmente importante à luz das transformações que ocorreram ao longo da última década. Aqui, os riscos sociais são enormes.

Habitação na era da financeirização

A centralidade do mercado habitacional na financeirização do capitalismo dos nossos dias tornou-se uma evidência cristalina com o papel desempenhado pelo chamado crédito subprime americano no espoletar da Grande Crise Financeira em 2008. Esse papel de rastilho da crise assinalava não só como a financeirização se havia entranhado na estrutura de economias crescentemente globalizadas, como apontava também duas dimensões relevantes para a nossa conversa sobre habitação. Em primeiro lugar, indicava a crescente discrepância entre a valorização dos ativos habitacionais/imobiliários ao longo das últimas décadas em contraponto a uma estagnação ou mesmo contração salarial nas economias centrais. Isso implicou um desequilíbrio crescente entre rendimentos do trabalho e rendimentos de propriedade imobiliária, e esse desequilíbrio traduziu-se em sociedades crescentemente endividadas - alimentando, por isso, recorrentes crises financeiras. $E$, em segundo lugar, apontava um processo que merece ser sublinhado nos debates sobre a governação neoliberal - a habitação foi não apenas um dos alvos da agenda de privatização e retração das políticas públicas desde o final dos anos 80 , como esse processo implicou que o imobiliário se tornasse num dos principais instrumentos de inscrição das lógicas de financeirização nas estratégias de reprodução social de largos segmentos sociais.

Este não é o local adequado para discutir aprofundadamente esse processo de financeirização da habitação - essa argumentação foi já adequadamente feita (Aalbers, 2008). No entanto, é de notar que a partir do final dos anos 80 o recuo da provisão pública na habitação foi patente em diferentes economias europeias: o stock público de habitação foi alvo de amplos processos de privatização nas últimas três 
décadas; e o próprio processo de desindustrialização das economias centrais alavancou uma nova centralidade do imobiliário nas economias centrais.

Estagnação salarial, desindustrialização, retrocesso da provisão pública e a própria volatilidade dos mercados financeiros alimentam a corrida à propriedade imobiliária - uma estratégia de "assetização" através de ativos imobiliários e de habitação, e que aposta na sua rentabilização. O sector imobiliário é, assim, aquele que mais ativos agrega no contexto global; e as estratégias de rentabilização desses ativos ganharam nos últimos anos uma dinâmica imparável, com a aquisição de largos stocks habitacionais por fundos financeiros; processos de renovação urbana a funcionar como instrumentos de gentrificação à escala quase planetária; e, mais recentemente, a expansão sem precedente de turistificação nas principais cidades mundiais - todas estas novas rentabilidades se apoiam grandemente no sector da habitação (Madden e Marcuse, 2016).

Daqui resulta uma mutação relevante: passamos da financeirização da habitação para a financeirização da cidade - isto é, passamos de rentabilidades que ofereciam propriedade habitacional a largos segmentos sociais em troca do seu endividamento, para um processo que aposta em rentabilizar o stock habitacional para procuras externas que não os próprios habitantes da cidade - classes transnacionais de gentrifiers e turistas - dispensando as classes sociais "locais" para encontrar rentabilidades mais aliciantes. Ora, por causa desta financeirização da cidade, têm-se multiplicado nos últimos anos em várias cidades europeias os alertas para a emergência de uma nova crise habitacional - "nova" porque não se assemelha às carências habitacionais populares que marcavam o pós-guerra na Europa, ou dos bairros de lata no Sul da Europa até aos anos 80. Agora, a crise atinge "novas" camadas sociais.

Como referiam Madden e Marcuse (2016), para os pobres a habitação é sempre crise e precariedade - assim, os atuais debates sobre crise habitacional assinalam antes as novas dificuldades dos estratos intermédios no acesso à habitação. Não deixa, contudo, de ser 
relevante essa ampla abrangência social do problema habitacional na atualidade, que atinge pobres, migrantes, e agora também jovens e classes médias. E aponta igualmente que $\mathrm{O}$ acesso à propriedade habitacional organiza uma dualidade cada vez mais relevante, que traduz desigualdades fundamentais nos níveis de bem-estar e na distribuição de possibilidades de rendimento entre diferentes grupos sociais nas economias financeirizadas da atualidade.

Habitação pós-pandemia em Portugal: uma crise em cima de outra crise?

No contexto da crise de 2011-2013, esta mudança da financeirização da habitação para a financeirização da cidade foi particularmente sentida em Portugal. A resposta à crise de 2011 assentou numa estratégia deliberada de rentabilização do sector da habitação, que foi lançada com a liberalização dos arrendamentos em 2012 e com a criação de instrumentos de captação de investimento ou procuras externas dirigidas ao imobiliário. As Autorizações de Residência para Investimento (vulgo, "vistos gold"); o Regime Fiscal para Residentes Não-Habituais; e a própria legislação que em 2014 enquadrou a multiplicação do alojamento local turístico sem restrições - procuraram ativamente investimento externo que alimentou o empolamento dos preços na habitação e criou sérias dificuldades a arrendatários, camadas jovens, trabalhadores precários e segmentos sociais de rendimentos baixos ou até intermédios nos principais centros urbanos (Santos, 2019). Só o concelho de Lisboa contava no final de 2019 perto de 20 mil alojamentos locais registados, e pode-se estimar tendo por base os valores de 20189 que cerca de $75 \%$ dessas ofertas se referiam a apartamentos inteiros e não apenas quartos. Os "vistos gold" injetaram no mercado imobiliário português nada menos do que 4,8 mil milhões de euros em cerca de 8 anos e concentraram-se principalmente na

\footnotetext{
9 Fonte: Inside Airbnb.
} 
AML.10 As casas disponíveis parecem já não se destinar aos usos e rendimentos dos trabalhadores e habitantes da metrópole.

A pergunta que agora se impõe é qual o efeito da crise pandémica neste panorama, face à forte contração económica que já vivemos e principalmente ao quase colapso do turismo urbano. Apontemos duas inquietações e uma possibilidade.

Comecemos pelas inquietações. Em primeiro lugar, é certo que nestes tempos de crises recorrentes do capitalismo financeiro, a demanda de securitização de investimentos por estratégias de assetização (compra de ativos imobiliários) parece sempre seguir o famoso mote do Barão de Rothschild quando aconselhava "compra quando houver sangue a correr nas ruas, mesmo que seja o teu". Pelo mundo fora, são múltiplos os fundos de investimento troteando os mercados financeiros transnacionais com vastos recursos financeiros, e a propriedade - o imobiliário - pode parecer um refúgio adequado para atravessar mais uma crise. Contudo, e apesar dos valores atingidos no mercado de venda de habitação não terem (ainda) assinalado a chegada de uma nova crise, especialistas e comentadores têm argumentado que é improvável que os preços do imobiliário não venham a cair. Em vários países os instrumentos legais que proibiram despejos ou moratórias nos pagamentos relativos à habitação estão ainda em vigor, e parecem ser essenciais para impedir uma onda massiva de perda de habitação de largos segmentos sociais. Muitos têm argumentado que é necessário que estes mecanismos perdurem no tempo - "há que proteger os senhorios deles próprios"11 - caso contrário assistiremos a uma brutal vaga de despejos, que inevitavelmente arrastará consigo o mercado de habitação.

Em segundo lugar, no contexto português é preciso ter em conta que a contração económica terá efeitos avassaladores sobre o emprego que se organizou em torno da nova centralidade da oferta turística nos

\footnotetext{
${ }^{10}$ Dados acumulados de outubro de 2012 a junho de 2020.

11 "Suspending evictions is about saving landlords from themselves", Notes from the crisis.
} 
centros urbanos. Sabemos que esse emprego no sector do alojamento e restauração se caracteriza por salários mais baixos e maior precariedade do que o conjunto da economia. O desemprego que, tudo indica, atingirá parte desses trabalhadores, terá consequências na capacidade desses segmentos de fazerem face às despesas de habitação e nos mercados habitacionais das regiões onde essa oferta turística é particularmente relevante: nos centros metropolitanos, no Algarve e na Madeira. A crise será urbana, e há que desenhar políticas que tenham em conta a fragilidade social destes segmentos de trabalhadores e a territorialização da quebra económica.

Daqui que a possibilidade colocada pelo atual contexto se prenda com o eventual regresso das políticas públicas de provisão de habitação. Essa possibilidade pode ser a chave para as perspetivas inquietantes. Em primeiro lugar, a crise global que se perspetiva parece implicar uma retração de procuras externas que têm alimentado a escalada especulativa dos preços na habitação em Portugal. Esse cenário, mesmo no contexto de dificuldades orçamentais, pode colocarse como uma oportunidade para reforçar o parque habitacional público, não só alargando uma oferta compatível com o rendimento da esmagadora maioria dos residentes como permitindo que as políticas públicas condicionem o próprio mercado de habitação. Em segundo lugar, o colapso da procura turística teve obviamente um efeito fulminante na oferta de alojamento local que floresceu nos últimos anos nas principais cidades - de um dia para o outro, milhares de casas ficaram vazias. Nesse contexto, surgiram programas públicos que procuravam encaminhar esse stock habitacional para o arrendamento acessível - os programas Renda Segura da Câmara Municipal de Lisboa (CML) ou Porto com Sentido, na capital nortenha - que se juntaram ao programa governamental Arrendamento Acessivel que vinha, igualmente, procurando estimular a oferta de habitação a preços comportáveis através de incentivos fiscais. Os dados disponíveis sobre os resultados destes programas não são, contudo, muito animadores. Em Lisboa, por exemplo, a imprensa noticiava que no final de julho a CML tinha recebido apenas 177 candidaturas no Renda Segura, e que 
menos de metade destas provinha de anterior arrendamento local. Estes dados parecem indicar que este tipo de programas só terá capacidade de ganhar escala se se tornar claro que no período póspandemia o alojamento local será fortemente regulado; caso contrário, as rentabilidades são de tal forma aliciantes que os proprietários resistirão a estabelecer contratos mais longos. Por fim, dada a intensidade da crise social e económica que se anuncia, é necessário que as políticas públicas procurem conter a queda de largos segmentos sociais em situações de pobreza e privação. Assim, a regulação do mercado habitacional, nomeadamente das rendas habitacionais, tem de ser um instrumento disponível para responder às necessidades das famílias.

Os riscos são, portanto, imensos: o perigo de aprofundar, no campo da habitação, uma desigualdade que perdurou na democracia portuguesa e que se agravou na sequência da crise de 2011-2013. Mas as possibilidades de enfrentar essa desigualdade estão igualmente presentes: trata-se de convocar as políticas públicas para desafiar a asfixia das crises que se acumulam.

\section{Referências bibliográficas}

Aalbers, Manuel (2008), The financialization of home and the mortgage market crisis, Competion \& Change, 12 (2), pp. 148-166.

Banco de Portugal (2020), COVID-19. Evolução das moratórias de crédito, 30 de junho de 2020.

IHRU [Instituto da Habitação e da Reabilitação Urbana] (2018), Levantamento Nacional das Necessidades de Realojamento Habitacional.

INE [Instituto Nacional de Estatístical (2020), COVID-19: O que distingue as 19 frequesias em estado de calamidade do resto da AML? Indicadores de contexto e de impacto socioeconómico da pandemia COVID-19 em Portugal. Em Destaque: informaçã̃o à comunicação social, 17 de julho.

Madden, David; e Peter Marcuse (2016), In Defense of Housing. The Politics of Crisis, Londres, Verso Books. 
Rodrigues, João; Ana Santos; e Nuno Teles (2016), A Financeirização do Capitalismo em Portugal, Lisboa, Conjuntura Actual Editora.

Santos, Ana (coord.) (2019), A Nova Questão da Habitação em Portugal - Uma abordagem de economia política, Lisboa, Conjuntura Actual Editora.

Serra, Nuno (2019), Quanto custa ser parente pobre? Do lugar periférico da habitação nas políticas sociais à sua centralidade no processo de financeirização, em Ana Santos (coord.) A Nova Questão da Habitação em Portugal - Uma abordagem de economia política, Lisboa, Conjuntura Actual Editora, pp. 275-291. 
Entrevista realizada a Ana Drago no âmbito da rubrica "Um olhar sociológico sobre a crise Covid-19", publicada a 4 de maio de 2020.

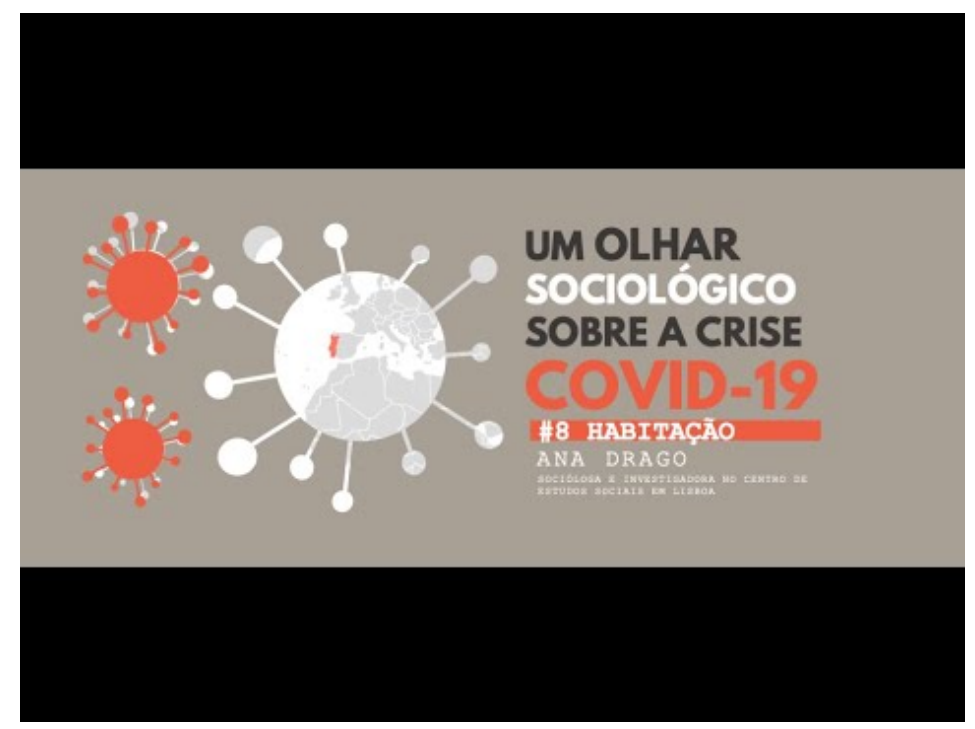




\section{CAPÍTULO 8}

PANDEMIA E AMBIENTE: IMPACTOS E CONSEQUÊNCIAS

\section{Luísa Schmidt}

Investigadora principal do Instituto de Ciências Sociais da Universidade de Lisboa

Em termos gerais, a pandemia veio revelar problemas e vulnerabilidades preexistentes. Desde logo, a vulnerabilidade de um sistema que entrou num imprudente descontrolo compulsivo, passando a criar mais problemas do que os que consegue resolver e deixando à vista vulnerabilidades ambientais, sociais, económicas, financeiras, laborais, territoriais, entre outras.

Neste texto começamos por ressaltar os impactos ambientais da Covid-19 tendencialmente positivos ou negativos. Passamos depois às mudanças sociais geradas ou potenciadas por esses impactos. Abordamos, por fim, as políticas públicas ambientais necessárias a várias escalas com ênfase na escala nacional.

Sobre os impactos ambientais da Covid-19

No caso das vulnerabilidades ambientais ficou evidente a pressão sobre os recursos naturais - renováveis ou não - que se está a exercer de forma insustentável. A pandemia veio reconfigurar a situação abrindo dinâmicas divergentes. Como constata um recente parecer do Conselho Nacional de Ambiente e Desenvolvimento Sustentável, "a experiência da pandemia é mista, revelando, por um lado, consequências sanitárias que as alterações climáticas e a intervenção desregrada na natureza não anteciparam, e, por outro, a desaceleração ou diminuição da intensidade de utilização de recursos naturais ao mesmo tempo que ocorre também a sua degradação" (CNADS, 2020: 3).

Assim, os impactos ambientais da pandemia, para além de globalmente muito nefastos, evidenciaram aspectos que se podem 
considerar "positivos" em algumas dimensões, a par de outros claramente negativos. De forma mais concreta, podemos destacar, no primeiro caso, a redução substancial da poluição atmosférica e da poluição sonora, sobretudo nas cidades. Uma geração urbana inteira experienciou pela primeira vez respirar ar limpo e até em certos casos ver o azul do céu como aconteceu em Nova Deli e em algumas cidades chinesas. E experienciou também o valor do silêncio urbano em contraste com o ruído do tráfego aéreo e rodoviário. Tornou-se inevitável assumir que a sociedade civil vai continuar a querer respirar melhor e, por isso, requerer junto das autarquias mais espaços verdes e menos automóveis, ou seja, ambientes urbanos mais inteligentes e saudáveis. Várias cidades europeias, como Milão, Paris ou Amsterdão, tomaram medidas neste sentido.

Lisboa, que é Capital Verde Europeia 2020, aponta tendencialmente no mesmo sentido, pois a apetência por uma cidade menos motorizada e mais verde já é evidente para os lisboetas. Mas não só Lisboa. Há quatro anos atrás, no rescaldo da saída da troika, o Primeiro Inquérito sobre Sustentabilidade em Portugal, realizado no âmbito do Observa (Observatório de Ambiente, Território e Sociedade), mostrou que durante a crise se, em geral, os portugueses tinham reduzido algumas actividades de lazer, havia duas práticas que haviam aumentado: passear em jardins públicos e parques naturais e, embora em menor grau, cultivar uma horta (Schmidt et al., 2018). Ou seja, a crise fez valorizar os espaços públicos verdes de usufruto gratuito que passaram a desempenhar um crescente papel compensatório no quotidiano dos cidadãos. Foi, aliás, uma prática que veio para ficar pois, em 2019, em pleno período de retoma, o Segundo Inquérito sobre Sustentabilidade em Portugal revelou que o uso e frequência de espaços públicos verdes expandira-se e afirmara-se como prática regular (Truninger et al., 2019). Hoje, no contexto pandémico, estes espaços tornaram-se ainda mais necessários, até à nossa própria sobrevivência, e restam poucas dúvidas quanto a que, num futuro próximo, a crise socio-económica vai levarnos a procurar cada vez mais os lazeres gratuitos, e as preocupações com a saúde física e mental vão fazer-nos requerer mais espaços verdes. 
Vimos, no caso de Lisboa, o Parque Florestal de Monsanto tornar-se num lugar de crescente fruição para os lisboetas, tal como o Corredor Verde para Monsanto, um projecto do arquitecto Gonçalo Ribeiro Telles inaugurado em 2013 para benefício de todos nós (Schmidt, 2016).

Lisboa e Porto necessitam de mais espaços verdes e livres, mas a situação vai muito para além dos centros das maiores cidades portuguesas, dado que ao nível suburbano as carências são maiores, pois aí multiplicaram-se os bairros construídos sem quaisquer condições de enquadramento e densidade, sem espaços públicos, muitas vezes sem árvores sequer.

Outro aspecto positivo do ponto de vista ambiental advém de uma tendência que já é anterior à crise pandémica e tem a ver com uma maior consciencialização dos consumidores. Nos dois inquéritos referidos sobre Sustentabilidade, aplicados em 2016 e em 2019, evidenciaram-se alguns grupos já significativos de consumidores que tendem a ser cada vez mais criteriosos e exigentes quanto à qualidade e às condições de produção ambientais, e que valorizam cada vez mais a produção de proximidade no que respeita aos produtos alimentares (Graça et al., 2019). São os chamados "prosumidores" e 'consumidores éticos' ou simplesmente advertidos e sensíveis à grave crise ambiental que o mundo atravessa. Trata-se de cidadãos que vivem tanto na cidade como no campo, mas renunciaram ao uso da maior parte dos plásticos, reduziram drasticamente o consumo alimentar não responsável nem justo, frequentam mercados biológicos ou compram cabazes online, e usam transportes amigáveis. Incluem-se também neste grupo os que já produzem a própria energia eléctrica que consomem.

A agricultura de proximidade assumiu uma maior visibilidade e um papel mais destacado, adquirindo relevância as cadeias curtas entre produção e consumo - "do prado ao prato" como propõe o Pacto Ecológico Europeu (Comissão Europeia, 2019). Não só pela racionalidade nas formas de produção como, sobretudo, pela necessidade evidenciada de maior autonomia alimentar no quadro nacional. Neste sentido, ficou também claro que o sistema de compras 
públicas - tanto para escolas como para hospitais, lares e serviços públicos - terá a beneficiar se recorrer directamente à produção nacional, em vez de manter o sistema habitual que apenas leva em conta o critério do preço. Estas mudanças acarretam também uma maior valorização do território e das paisagens, ou seja, das Áreas Protegidas e dos ecossistemas naturais que são o nosso garante vital da saúde pública à biodiversidade, até aos recursos básicos como água, solo e ar.

A pandemia acentuou também vários aspectos negativos do ponto de vista ambiental. Desde logo, houve um abrandamento relativamente à recolha de resíduos urbanos - com a suspensão temporária da recolha porta-a-porta, e o aumento dos descartáveis de plástico com um destino incerto, habitualmente desadequado e ainda sem resposta eficaz. Este é um problema a necessitar de uma resposta urgente, que passa desde já pela promoção de campanhas de comunicação e controlo, de modo a evitar a sua transformação num problema ambiental de grande alcance.

Um segundo aspecto negativo tem a ver com o agudizar de um problema crítico anterior, o da pobreza energética, agravado pela impreparação das habitações para enfrentar ondas de calor e frio. Analisados os índices de mortalidade causados pelo frio na União Europeia (UE), os dados mostram que, por absurdo, se morre menos de frio na Finlândia do que em Portugal (Eurostat, 2020). Parece bizarro, mas no fundo não é. Muitos de nós já ouvimos estrageiros do Norte e Centro da Europa queixarem-se do frio que passam em Portugal dentro de casa, apesar do sol que cá vieram procurar. No nosso país uma grande parte das casas são miseravelmente isoladas. Não têm dispositivos estruturais de climatização e, por isso, as pessoas vivem numa vulnerabilidade extrema ao frio, e sobretudo ao nosso frio húmido do Atlântico. Este facto denuncia outro: Portugal tem um índice de pobreza energética diametralmente oposto ao da Finlândia e um dos mais elevados da UE, ficando apenas atrás de dois países do exleste (Horta et al., 2019). Há inúmeras doenças crónicas - sobretudo de 
índole respiratória, cardiovascular e reumática - provocadas ou agravadas por este problema do mau desempenho energético das habitações. A mesma reflexão pode ser replicada na situação inversa das ondas de calor. Nem isolamentos, nem ensombramentos, nem o respeito por regras de orientação do edificado ou das cérceas, nem por tradições úteis que protegiam as casas e os espaços públicos das canículas, têm sido devidamente respeitados num mundo de prédios e loteamentos densos. Acresce que as alterações climáticas vieram agravar toda esta condição disseminada pelo país, que se alastra com uma dinâmica mais vasta do que a prevista.

Com o aumento das carências económicas e a necessidade de confinamento provocado pela pandemia, o problema da impreparação dos edifícios que habitamos tornou-se cada vez mais premente. É, pois, urgente pensar a vida, as casas e os espaços públicos em termos de segurança térmica e da saúde pública que lhes está associada. Para isso conta-se também com uma dimensão importante do Pacto Ecológico Europeu e respectivo Fundo de Transição Justa, através de um pacote financeiro especificamente dedicado para investimentos a realizar na eficiência energética dos edifícios, na criação de comunidades energéticas, na micro geração de electricidade e nas redes inteligentes (vide também o PNEC 2030, em Ministério do Ambiente e da Transição Energética (2020)). Tudo para melhorar o conforto térmico, a qualidade do ar e a saúde pública, reduzindo as referidas bolsas de pobreza energética que nos indignam e envergonham no quadro europeu.

Impactos ambientais e mudanças sociais

Se estes impactos - positivos e negativos - serão geradores de mudanças sociais efectivas, ainda é prematuro afirmar. Mas há mudanças na área do ambiente que serão inevitáveis, dado que a crise pandémica também veio chamar a atenção para a possibilidade de outros colapsos que continuam ameaçadores, como é o caso das crises da biodiversidade e das alterações climáticas. 
A crise da biodiversidade tem sido particularmente referida, pois muitos cientistas relacionam este vírus com causas zoonóticas, ou seja, com a excessiva intervenção humana nas florestas tropicais e na devastação de ecossistemas e da vida selvagem, alertando para outras pandemias que the poderão suceder se continuar este processo de destruição ambiental. O mais recente relatório Living Planet Report (WWF, 2020) vem tornar clara a situação dramática das perdas de biodiversidade global: entre 1970 e 2016 as populações de mamíferos, aves, peixes, répteis e anfíbios sofreram um declínio de $68 \%$, sendo que, nas águas doces, o decréscimo atingiu $84 \%$. Acresce que os oceanos encontram-se profundamente poluídos e cerca de $85 \%$ das zonas húmidas interiores e costeiras foram perdidas. Mais grave ainda, o declínio de $94 \%$ nas populações animais verificado na América Latina e Caraíbas é muito maior do que em qualquer outra região.

Por seu lado, as alterações climáticas, que continuam com os seus impactos a vários níveis, podem gerar outros colapsos - desde a subida do nível do mar, aos eventos extremos, às ondas de calor e frio, bem como o potencial surgimento de vectores geradores de doenças, passando pelas secas prolongadas e incêndios. Tudo fenómenos geradores do aumento do número de refugiados ambientais e climáticos obrigados a abandonar países e regiões ambientalmente - e muitas vezes politicamente - destruídos. Num relatório do Instituto para Economia e Paz de Sydney (2019), as previsões para 2050 apontam para mais de mil milhões de migrantes por motivos ambientais, onde se destaca as que resultam em escassez de água.

Reflectindo mudanças sociais importantes, tornam-se cada vez mais notórios novos movimentos cívicos ambientais chamando a atenção para os problemas da insustentabilidade do sistema em que vivemos. Parecendo por vezes modestos e às vezes defensivos, estes movimentos cívicos têm-se instalado e multiplicado de forma progressiva e diversificada. É o caso dos chamados "movimentos de transição" que integram em geometrias muito variáveis experiências que passam pela permacultura, transição energética, conservação da biodiversidade e paisagem, mas também por projectos como as 
eco-aldeias, as comunidades em rede dentro de áreas protegidas dedicadas à conservação do património natural e cultural, ou até os designados "novos rurais", dedicados a produções biológicas e à recuperação de espaços abandonados ou improdutivos. Muitas vezes não constituem organizações, não estão juridicamente formatados, nem têm ambições políticas institucionais. São pessoas que decidiram, individual ou colectivamente, mudar de vida e fundar a sua existência às avessas das insustentabilidades.

Estas experiências têm em comum a vontade de construir um modelo de vida em harmonia com a Natureza e, na sua maior parte, encontram-se ligadas em rede e integradas em projectos conjuntos de escala maior, como é o caso do Ecolise (European Network for Community-Led Initiatives on Climate Change and Sustainability), ou do movimento das chamadas ecoaldeias - a Global Ecovillage Network que, aliás, já conta com 26 casos em Portugal.

Refiram-se também os recentes movimentos sociais de jovens ambientalistas, sobretudo os inspirados pelas rupturas trazidas pelas alterações climáticas. $\bigcirc$ mais visível actualmente é sem dúvida o da Greve Climática - Fridays for the Future - um movimento juvenil que ganhou corpo sob a inspiração de Greta Thunberg, mas que evidentemente nunca teria existido nem expandido a este ponto se a preocupação climática não estivesse já latente entre esta nova camada juvenil. A consciência destes jovens adolescentes, entre o final do secundário e o início do universitário, hábeis nas redes sociais e de informação que a web faculta, conseguiu estruturar um importante movimento que já hoje desafia os poderes políticos e institucionais a todos os níveis.

Este movimento da greve pelo clima é, aliás, dos fenómenos políticos mais curiosos e interessantes a que se assistiu ultimamente. Mas não é o único. Outros movimentos têm surgido, alguns mais radicais, posicionando-se contra o sistema da insustentabilidade global no uso e abuso de recursos finitos ou poluentes. É o caso do Extinction Rebellion, que surgiu em Inglaterra em 2018 e já se expandiu a outros 
países europeus. Manifestam-se através da desobediência civil contra as políticas e actividades ambientalmente danosas.

Há ainda à escala internacional o movimento Blockadia - sobretudo constituído por comunidades resistentes ao extractivismo. E há o Climate Justice Action (criado pós a COP 21), o Climate Reality Project (criado por Al Gore) e o 350.org (liderado por Bill McKibben desde 2009) que lutam, numa base não violenta, contra as alterações climáticas e por uma transição energética limpa e justa. Todos estes movimentos sociais viram realçada a sua importância com a crise pandémica.

Ainda não sabemos as consequências desta tragédia, mas, em termos do que são as práticas sociais instaladas, haverá certamente mudanças sociais que se vão reflectir também no ambiente. Desde logo, as novas rotinas de distanciamento e das limitações à concentração social estão a alterar a nossa relação com o consumo, bem como as deslocações e as viagens. Tudo indica que, nos próximos anos, haverá menos viagens aéreas, mais teletrabalho e, por isso, menos deslocações diárias, bem como alterações na produção e nos consumos - iremos consumir de forma diferente, produzir mais alimentos e outros bens a uma escala mais próxima porque precisamos de maior segurança e de investir em soluções da economia circular para poupar recursos (Sarkis et al., 2020).

\section{Políticas públicas renovadas}

Para ancorar todo este potencial de mudança serão necessárias políticas públicas inovadoras e efectivas na área do ambiente a diversas escalas: do global ao local. À escala europeia temos o já referido Pacto Ecológico Europeu que inclui um programa de políticas públicas para uma transição justa organizadas em 10 acções principais: desde a acção climática e energia limpa, à mobilidade e construção sustentáveis, passando pela conservação da biodiversidade e a ecologização da política agrícola comum, até à economia circular, financiamento e investimentos obrigatoriamente sustentáveis. 
No entanto, nenhum Pacto Ecológico ou Green Deal terá verdadeiro sucesso se não tiver ressonância global. Ou seja, se não houver apoio directo à capacitação para os países mais pobres, não haverá justiça ambiental e, portanto, não haverá saída para a crise ambiental global num mundo sem fronteiras e interligado. Ninguém está imune; ninguém está dispensado.

Como refere o Papa Francisco na Encíclica Laudato Si (2015), os problemas ambientais estão directamente ligados aos problemas das desigualdades, não sendo possível pensar uns sem os outros, pois o ciclo é vicioso: a degradação dos recursos vai de par com a degradação social e humana. A encíclica sublinha a dívida dos países do Norte pelo uso e abuso dos recursos naturais e pelo excesso das suas emissões fósseis - aos países mais pobres do Sul, que já sofrem as consequências das alterações climáticas e que agora vêem a sua situação dramaticamente agravada pelos impactos da Covid-19. $\bigcirc$ problema da dívida - das dívidas - está hoje mais do que nunca na ordem do dia e tem que ser assumido. Não se trata apenas de reequacionar a(s) dívida(s), mas sim de a(s) pagar objectivamente com a transferência de conhecimento e tecnologias limpas e apropriadas; apoios explícitos à capacitação; assistência técnica e manutenção dos recursos de sobrevivência (água, floresta, recursos marinhos, etc.). Num mundo global e interdependente não se trata apenas de uma obrigação, mas de uma medida inteligente de segurança, uma espécie de investimento na nossa sobrevivência colectiva. O Green Deal terá mesmo que ser global.

Quanto a Portugal, precisamos de mudanças decisivas. A crise mostrou que são necessárias políticas preventivas, cientificamente baseadas, para evitar novos colapsos e assim diminuir as suas consequências devastadoras. Entre estas destacam-se sete áreas-chave, a começar pela água, um recurso vital e transversal que é preciso monitorizar em contínuo - acautelando aquíferos e caudais, com especial atenção aos rios internacionais, bem como uma gestão de proximidade, por região hidrográfica, como prevê a Directiva Quadro 
da Água transposta em 2005 para a Lei da Água. Implícito está também o combate à desertificação e seca.

Em segundo lugar, é urgente uma política dinâmica para a conservação da natureza, dado que o que temos hoje é o estado lastimável em que se encontram as estruturas administrativas do actual Instituto da Conservação da Natureza e Florestas (ICNF) e a visível delapidação do nosso património de biodiversidade e paisagem, devido aos incêndios, à urbanização, à agricultura intensiva e a muitos outros abusos dos recursos naturais. É preciso inverter este processo, pois o Sistema Nacional de Áreas Classificadas (SNAC) é a base do metabolismo da riqueza nacional que tudo assegura - desde a biodiversidade, sem a qual não haverá nem agricultura, nem alimentos, até à qualidade da água, à saúde pública, passando pelo património natural e cultural. As Áreas Protegidas, que integram o SNAC, são um fulcro da soberania nacional e da nossa articulação territorial, implicando uma política pública séria que tarda a ser implementada.

Um terceiro aspecto, bem na vizinhança de uma política que nos faz falta para a conservação da natureza, é a gestão das florestas, cujo impulso depois da tragédia dos incêndios de 2017 corre o risco de ficar esmorecido se não se der continuidade e reforço às iniciativas que foram tomadas ou anunciadas. Urge, pois, uma política florestal continuada que permita a gestão da floresta em Portugal e privilegie o ordenamento, os povoamentos mistos e o controle de espécies mais combustíveis, bem como a elaboração do cadastro (Castro Rego et al., 2020). A floresta multidiversa tem de ser incentivada; a tragédia dos incêndios tem que ser eliminada.

Em perigo está também a nossa linha de costa e esse é o quarto aspecto a sublinhar. $O$ desordenamento do território e o caos administrativo na faixa litoral permitiram uma ocupação insana, incluindo em zonas de vulnerabilidade extrema expostas à erosão, subida do mar e tempestades de intensidade crescente. $O$ país continua a não ver aplicar na sua linha de costa uma política pública de retirada e recuo, de renaturalização e, o que é mais absurdo, de suspensão de novas ocupações como continuam a acontecer. A linha de 
costa deveria estar sujeita a um regime de "emergência climática" e sob gestão de uma agência que integrasse funcionalmente as 93 instituições e mais de 100 leis que intervêm actualmente sobre a gestão do litoral (Duarte Santos et al., 2015).

Em seguida, a mobilidade urbana e metropolitana. As auréolas crescentes de residentes pendulares obrigam a um vaivém que continua a ser suprido sobretudo pelo automóvel particular. Agora que já foi dado um passo fundamental com o passe Navegante, torna-se urgente melhorar os equipamentos de transporte eléctrico. Para mais, essa é uma das prioridades do Pacto Ecológico Europeu, e o país precisa como de pão para a boca, ou melhor, como de ar para os pulmões, de aproveitar fundos e dotar-se finalmente de uma rede pública de comboio, de metro e de redes diversificadas de mobilidade limpa, reforçando seriamente o transporte colectivo bem como o transporte eléctrico de pessoas e mercadorias.

Articulada à mobilidade limpa, segue-se a urgência de alterar a nossa condição energética, considerando princípios básicos de justiça social, o que passa pela já referida expansão da autonomia energética, das redes inteligentes à escala local, e do apoio à eficiência energética e isolamento térmico das habitações "sem deixar ninguém para trás", como refere o Pacto Ecológico. Já o referimos, não podemos continuar a bater os recordes europeus da pobreza energética e, se não houver políticas públicas explícitas e inclusivas para a reconversão do parque habitacional em termos da sua eficiência energética, tudo se agravará. Para que isso seja eficaz é necessário chegar às pessoas e alargar o entendimento público da questão da energia e, por isso, tornam-se fundamentais novos processos de envolvimento cívico e social e uma cultura de ciência participativa.

Por seu lado, a agricultura terá de garantir actividades estratégicas para o abastecimento interno seguro, dentro de uma política integrada de conservação da natureza e de uma infra-estrutura nacional que proteja os solos e a água, ou seja, o futuro.

Finalmente, para um país que se habituou ao sucesso rápido do turismo e que acabou por ficar dele dependente, a pandemia trouxe 
um alerta que não pode ser ignorado: o turismo industrial de massas em descontrole destrói mais recursos do que aqueles que vem utilizar e não traz rendimento nem emprego estáveis ao país.

A grande oportunidade que temos agora baseia-se em perceber a importância do ambiente, da sustentabilidade e das exigências ambientais e sanitárias para um futuro menos vulnerável. Não se trata de promover o regresso a uma economia da "pedra lascada", mas sim o avanço para uma modernidade com futuro. O país tem hoje boas condições para isso: boa ciência e tecnologia; unidades industriais criativas; e alguns recursos e condições positivas a começar pelo mar, pelo vento e pelo sol, bem como outros recursos naturais. Recordemos as águas, termais ou não, e o seu enorme potencial para a regeneração ambiental e paisagística, para a saúde e para um turismo sustentável.

Em suma, para que os impactos desta pandemia se possam tornar uma grande oportunidade para corrigir deficiências crónicas do país, é preciso olhar de frente para alguns obstáculos crónicos ao nosso desenvolvimento inteligente, acima de tudo a educação e as desigualdades sociais. É a partir da correcção destes obstáculos que poderemos transformar a pandemia e as suas crises num começo novo para um futuro mais equilibrado, sustentável e até mais produtivo.

\section{Referências bibliográficas}

Castro Rego, Fancisco; Paulo Fernandes; Joaquim Sande Silva; João Azevedo; José Manuel Moura; Emanuel Oliveira; Rui Cortes; Domingos Xavier Viegas; Duarte Caldeira; e Filipe Duarte Santos (coords) (2020), Observatório Técnico Independente, Relatório de atividades do Observatório Técnico Independente referente ao $1 .^{\circ}$ semestre de 2020, Lisboa, Assembleia da República.

\section{Comissão Europeia (2019), Pacto Ecológico Europeu.}

Conselho Nacional do Ambiente e Desenvolvimento Sustentável (CNADS) (2020), Reflexão do CNADS sobre Desenvolvimento Sustentável e Inclusivo na fase pós-COVID 19 e Visão Estratégica para o Plano de Recuperação Económica de Portugal 2020-2030, Lisboa, CNADS. 
Duarte Santos, Filipe; António Mota Lopes; Gabriela Moniz; Laudemira Ramos; e Rui Taborda (2015), As Recomendações do Relatório do Grupo de Trabalho do Litoral - 2014 e a sua aplicação. Actas do VIII Congresso sobre Planeamento e Gestão das Zonas Costeiras dos Países de Expressão Portuguesa, Universidade de Aveiro, Portugal, pp. 1-9.

Eurostat (2020), Inability to keep home adequately warm - EU-SILC survey.

Graça, João; Monica Truninger; Luís Junqueira; e Luísa Schmidt (2019). "Consumption orientations may support (or hinder) transitions to more plantbased diets", Appetite (140), pp. 19-26.

Horta, Ana; João Guerra; Madalena Dias Santos; e Luísa Schmidt (2019). "Pobreza energética: análise da utilização doméstica de energia, habitação adequada e transportes acessíveis ". em Ferrão, J. e Delicado, A. (eds.), Portugal Social em Mudança. Objectivos de desenvolvimento sustentável, Lisboa, Instituto de Ciências Sociais da Universidade de Lisboa, pp. 37-45.

Instituto para Economia e Paz de Sydney (2019) Índice Global da Paz, Sydney Austrália.

Ministério do Ambiente e da Transição Energética (2020), Plano Nacional Energia e Clima 2021-2030 (PNEC 2030).

Papa Francisco (2015) Carta Encíclica Laudato Si do Santo Padre Francisco Sobre o Cuidado da Casa Comum, Vaticano.

Sarkis, Joseph; Maurie J. Cohen; Paul Dewick; e Patrick Schroder (2020), "A brave new world: Lessons from the COVID-19 pandemic for transitioning to sustainable supply and production", Resources, Conservation \& Recycling, 159.

Schmidt, Luísa (2016), Portugal: Ambientes de Mudança. Erros, Mentiras e Conquistas, Lisboa, Temas e Debates e Círculo de Leitores.

Schmidt, Luísa; Monica Truninger; João Guerra; e Pedro Prista (2018), Sustentabilidade. Primeiro Grande Inquérito em Portugal, Lisboa, Imprensa de Ciências Sociais.

Truninger, Monica; e Luísa Schmidt (coord) (2019), Segundo Grande Inquérito sobre Sustentabilidade em Portugal - Relatório Síntese, OBSERVA ICSULisboa. 
UM OLHAR SOCIOLÓGICO SOBRE A CRISE COVID-19 EM LIVRO

WWF (2020), Living Planet Report 2020, World Wide Fund for Nature (WWF). 
Entrevista realizada a Luísa Schmidt no âmbito da rubrica "Um olhar sociológico sobre a crise Covid-19", publicada a 22 de maio de 2020.

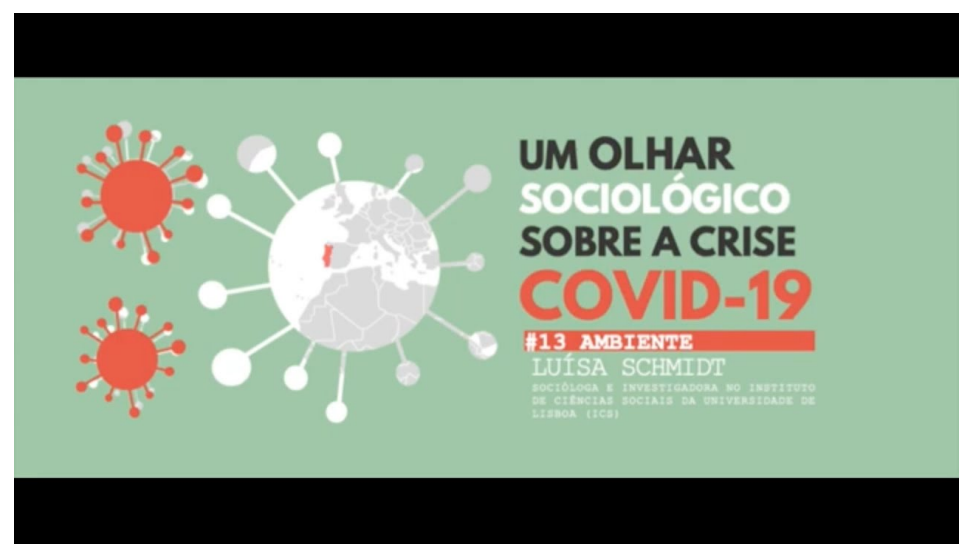




\section{CAPÍTULO 9}

COVID-19 E DESIGUALDADES DE GÉNERO: UMA PERSPETIVA INTERSECCIONAL SOBRE OS EFEITOS DA PANDEMIA

\section{Sofia Aboim}

Instituto de Ciências Sociais da Universidade de Lisboa

Vários meses depois de o primeiro caso de Covid-19 ter sido registado em Portugal, a 2 de março de 2020, os números da pandemia continuam a crescer diariamente, sem previsão exata da real dimensão que assumirá a crise económica e social que se alarga a cada dia.

Em qualquer dos cenários, 2020 marca o início de uma crise de efeitos devastadores, apenas comparáveis aos embates provocados pelos mais graves colapsos dos últimos 150 anos. E tal como no passado sucedeu com a grande maioria dos eventos traumáticos, a Covid-19 colocou a nu os regimes de desigualdade que estruturam as nossas sociedades, denunciando as fragilidades das políticas de combate à exclusão, marginalização e desigualdade, em geral.

Em pouco tempo esfumou-se, nas mensagens mediáticas, a metáfora igualitária que nos bombardeou no início da pandemia e o "vírus democrático" rapidamente cedeu lugar ao "vírus da desigualdade" (entre as quais a de género, Amador, 2020), porque afinal "não estamos nisto todos juntos" (Bowleg, 2020). Em pouco tempo vieram à tona as enormes fraturas da nossa sociedade, denunciando a vulnerabilidade de muitos grupos sociais e a precariedade dos esforços para garantir os seus direitos a uma plena igualdade. A Covid-19 gerou certamente uma crise, mas veio sobretudo agravar as desigualdades que já existiam, pondo a sociedade diante do espelho, agora visto pelas lentes de um aumento do efeito de lupa.

Invariavelmente, a crise sanitária e económica atinge mais penosamente quem é mais vulnerável, seguindo linhas de género, classe, racialidade ou geração, como sistematicamente têm apontado 
as teorias da interseccionalidade (Hill Collins, 2019). ${ }^{1}$ Sabemos que a pobreza, o desemprego, a falência dos pequenos negócios, a precariedade e a incerteza aumentaram a pique. Sabemos que a crise sanitária é arrasadora para a economia, lançando milhões na pobreza e desemprego. Mas sabemos igualmente que estas desigualdades aumentam ainda mais entre as mulheres, acentuando as disparidades entre homens e mulheres e, sobretudo, expondo as frágeis fundações do regime de género na nossa sociedade (Walby, 2020). A 21 de julho de 2020 lia-se, no blogue do Fundo Monetário Internacional, um retrato funesto das desigualdades de género provocadas pela pandemia da Covid-19. Apenas meses depois dos primeiros casos serem públicos, "A pandemia da Covid-19 [já] ameaça reverter os ganhos obtidos em termos de oportunidades econômicas para as mulheres e, assim, ampliar as disparidades de gênero que persistem apesar de 30 anos de avanços." (Georgieva et al., 2020: 1). Com efeito, a crise sanitária tem sido o gatilho de gritantes desigualdades, cujo diagnóstico exige tanto uma perspetiva de género quanto lentes interseccionais, isto é, ajustadas para identificar os "cruzamentos" onde o aumento das disparidades tem sido maior. Exige ainda que se faça uma pergunta mais importante, a de saber porque é que a igualdade conquistada pelas mulheres e por minorias $\mathrm{LBGTIQ}+$ ou étnico-raciais, entre outras, continua repetidamente a ser a primeira a fragilizar-se ou mesmo a cair. Esta é a indagação que orienta esta nossa reflexão, ainda algo perplexa com a fria clareza dos números.

Afinal não estamos todos no mesmo barco: o género da pandemia

A muito maior vulnerabilidade das mulheres e raparigas aos efeitos catastróficos da pandemia traz consigo pouca ou nenhuma novidade. Se é verdade que a pandemia tem género, o impacto do

\footnotetext{
1 Mais especificamente, a teoria da interseccionalidade, hoje dominante nas análises das relações de género, propõe, como avança Hill Collins (2019: 151), uma "análise que afirma que os sistemas de raça, classe social, género, sexualidade, etnia, nação, e idade mutuamente formam as características construtivas da organização social." Neste sentido, importa mais identificar as matrizes da dominação do que advogar a precedência de uma desigualdade sobre outra.
} 
SARS-CoV-2 limita-se, não obstante, a seguir um trajeto semelhante aos efeitos de outras emergências sanitárias (Nunes, 2019; Diniz, 2017). O novo coronavírus desencadeou uma crise social, que relembra, acima de tudo, a persistência de resistentes estruturas patriarcais nas sociedades contemporâneas. As fundações de uma ordem de género em que o feminino é o elemento subordinado têm sido difíceis de destruir, ressurgindo vitalizadas ao mínimo abalo. Sendo certo que os efeitos da pandemia da Covid-19 estão longe de ser superficiais, também é verdade que a disparidade entre mulheres e homens se tornou notória quase de imediato, quase antecipando outros impactos económicos e sociais, tal a celeridade com que abalou as estruturas da vida quotidiana. Ao contrário da ética dos ideais cavalheirescos do passado, em que se devia salvar as mulheres e as crianças, protegendo-as da sua alegada fragilidade, as crises mostram uma realidade bem diversa, que tende a repetir-se. Desta vez não foi diferente. Mas, das heranças patriarcais, sobrou muito mais o lado negro da subordinação do que os mitos de heróis protetores de face masculina.

Em geral, quando comparadas com os homens, as mulheres são sempre mais afetadas pelos efeitos sociais e económicos de surtos de doenças infeciosas. Inúmeros estudos o têm demonstrado (Human Rights Watch, 2017, entre outros). São habitualmente elas quem suporta o peso das tarefas da casa e das responsabilidades de cuidados à medida que as escolas fecham e os membros da família ficam doentes (Wenham et al., 2020a e 2020b; Cerqueira, 2020). Não é por acaso que, em Portugal, segundo dados de junho de 2020, foram sobretudo as mulheres a fazerem pedidos de apoio excecional à família. Cerca de $81 \%$ dos pedidos foram submetidos por mulheres (Gabinete de Estratégia e Planeamento do Ministério do Trabalho, Solidariedade e Segurança Social). A pandemia não penaliza, contudo, apenas as mulheres no papel de cuidadoras. Em fases mais jovens da vida, ainda antes da chegada dos filhos, as raparigas, já mais atingidas pelo desemprego e a precariedade, são igualmente as mais afetadas pela pandemia. Como alerta a Organização Mundial do Trabalho, pelo 
menos um em cada seis jovens entre os 18 e os 29 anos deixará de trabalhar devido à Covid-19, proporção que será maior entre as mulheres jovens. As mulheres são, efetivamente, as principais vítimas do desemprego. Mundialmente, os empregos das mulheres são 1,8 vezes mais vulneráveis a esta crise do que os empregos dos homens. As mulheres representam 39\% do emprego global, mas são responsáveis por $54 \%$ da perda global de postos de trabalho. Uma razão para este maior efeito nas mulheres é que o vírus está a aumentar significativamente a carga de cuidados não remunerados, que é desproporcionadamente transportada pelas mulheres. Isto, entre outros fatores, significa que o emprego feminino está a diminuir mais rapidamente do que a média, também consequência do facto de mulheres e homens trabalharem em diferentes sectores. Em Portugal as tendências manifestam a mesma realidade. Entre abril de 2019 e abril de 2020, desapareceram 85 mil empregos; 66\% eram de mulheres (Expresso, 2020). Por comparação com o primeiro trimestre de 2020, no segundo trimestre do ano, o desemprego das mulheres cresceu cerca de $26 \%$ ao passo que o dos homens apenas aumentou $12 \%$ (fonte: Pordata).

São também as mulheres quem mais revelou sentir as agruras do confinamento durante o período de Estado de Emergência vivido na primavera de 2020. Como mostraram vários inquéritos realizados em Portugal durante o período de confinamento, eram elas quem revelava maiores níveis de stress, sobrecarga e mesmo maior pessimismo, assim como maiores dificuldades de ajustamento entre o regime de teletrabalho e a vida doméstica e familiar (Magalhães et al., 2020; Silva et al., 2020; Escola Nacional de Saúde Pública, 2020). O confinamento e as medidas de saúde pública destinadas à contenção da infeção afetaram profundamente as mulheres, desde a vida doméstica e profissional até às experiências de gravidez e parto, submetidas, também estas, a formas de controlo sanitário rigorosas (Barata et al., 2020). Por outro lado, o acesso à saúde sexual e reprodutiva, incluindo o direto à interrupção voluntária da gravidez, ficou comprometido, 
quando não posto em causa (veja-se, sobre os EUA, o artigo de Bayefsky et al., 2020).

O impacto negativo sobre as mulheres e a igualdade de género repete-se sem que nada tenha entretanto sido feito para mitigar o problema. Houve seguramente um fracasso em aprender com a história recente da crise do Ébola em três países africanos em 2014, do Zika em 2015-16, dos recentes surtos de síndrome respiratória aguda, gripe suína e gripe das aves. Os rendimentos femininos sofreram quedas maiores e mais difíceis de recuperar até hoje. Agravando o impacto sentido pelas mulheres, a violência doméstica cresceu também exponencialmente, e como antes tinha sucedido, um pouco por todo o mundo. O surto de Ébola que grassou na África Ocidental em 2014-2015 revelou que mulheres e meninas sofreram altos índices de violência e abuso sexual, ao mesmo tempo que enfrentaram escassez de abrigo e cuidados de saúde. No surto de Ébola na República Democrática do Congo foi difícil oferecer serviços específicos de saúde sexual e reprodutiva, incluindo atendimento a sobreviventes de violência familiar. A mesma "epidemia silenciosa" gerada pela violência constitui também legado do vírus Zika, cujos efeitos afetaram muitíssimo mais as mulheres do que os homens, quando usamos lentes comparativas. Com efeito, a violência de gangues no Brasil impactou diretamente $\mathrm{o}$ acesso das mulheres a serviços de saúde sexual e reprodutiva durante a crise do Zika, com redes informais a exercerem controlo sobre quem tinha ou não acesso a tratamentos médicos. Essa emergência de saúde criou epidemias semelhantes de violência sexual e doméstica em situações de alto risco, aumentando a vulnerabilidade já experienciada no feminino.

Como esperado, a pandemia da Covid-19 não está a ser diferente, repetindo-se a associação entre traumas ou crises e violência contra as mulheres enquanto fenómeno global. Na Turquia, Argentina, Canadá, França, Alemanha, Espanha, Reino Unido ou EUA (UNWomen, 2020), as autoridades governamentais, os ativistas dos direitos das mulheres e os parceiros da sociedade civil têm assinalado relatos crescentes de violência doméstica e sexual. As linhas de ajuda em Singapura, Malásia, 
Chipre ou Austrália haviam registado um aumento das chamadas em mais de $30 \%$ durante os meses do grande confinamento, abril e maio. Como referiu o secretário geral das Nações Unidas, António Guterres, no início de abril, tem havido um "horrendo aumento global da violência doméstica". No contexto europeu, os números são preocupantes e Portugal não é exceção. Segundo dados da Rede Nacional de Apoio às Vítimas de Violência Doméstica, após uma quebra de cerca de 39\% nos pedidos de ajuda durante o período de confinamento, as solicitações dispararam para o dobro com o desconfinamento. Por seu lado, a linha de apoio da Comissão para a Cidadania e a Igualdade de Género (CIG) recebeu 727 contactos entre 19 de março e 15 de junho, o que representa um aumento de $180 \%$ face ao primeiro trimestre de 2020. Segundo a Associação de Apoio à Vítima (APAV), o número de mulheres com mais de 65 anos a pedir ajuda tem aumentado e revelou-se ainda mais evidente após a pandemia (Público, 2020).

Intersecções: para além do género

As mulheres têm sofrido e continuam a sofrer o impacto da crise sanitária com mais força, realidade que afeta a esmagadora maioria das mulheres por comparação com os homens. Não é por acaso que as mulheres muito qualificadas, docentes universitárias e investigadoras científicas, viram a sua produtividade cair em comparação com a dos homens. As responsabilidades familiares acrescidas e a sobrecarga de trabalho que o confinamento aumentou tiveram visível impacto sobre a produtividade profissional, com o número de publicações autoradas por mulheres a diminuírem manifestamente, ao contrário do que sucedeu com os homens durante o mesmo período, em que houve, antes, um aumento da produtividade (ver o estudo de Kim e Patterson, 2020). Quer isto dizer que os efeitos diferenciados do género se fazem sentir entre mulheres de todos os grupos socioeconómicos, em maior ou menor grau. 
Porém, é entre as mulheres mais desfavorecidas economicamente, as migrantes, as portadoras de deficiência ou entre as minorias LBGTIQ+ que mais dramáticos se têm feito sentir os impactos da Covid-19. No mundo, e em Portugal, as múltiplas desigualdades aumentadas pela crise pandémica têm afetado com mais rigor quem está em situação de maior vulnerabilidade, ocupando uma posição na intersecção de vários fatores de desvantagem. Entre estes tem-se destacado a raça e a etnia, elementos sobre os quais não existem dados em Portugal. Mas sabemos que pessoas migrantes e de minorias étnicas estão tanto a morrer mais como a sentir maior exclusão e vulnerabilidade à pobreza nos EUA, Reino Unido ou Brasil (veja-se para - Brasil, Santos et al., 2020). Independentemente de quaisquer explicações sobre a vulnerabilidade à contração da infeção, importa salientar que é a acumulação de desvantagens que se torna responsável pelo padrão social de impacto da pandemia. Não é por acaso que na Área Metropolitana de Lisboa a infeção se agigantou na periferia suburbana da cidade, atingindo populações específicas. Na verdade, o género, a etnicidade, a classe social, a orientação sexual ou a identidade de género constituem fatores de desvantagem evidente.

Neste sentido, a interseccionalidade permite-nos desafiar comparações simples entre homens e mulheres para perguntar, ao invés, que mulheres e que homens são específica e desproporcionadamente afetados pela Covid-19. Como revela a teoria da interseccionalidade, a homogeneização dos grupos (por exemplo, homens versus mulheres) tende habitualmente a privilegiar as experiências de quem é relativamente privilegiado dentro do grupo (por exemplo, mulheres portuguesas brancas, heterossexuais e de classe média). Desta forma, corre-se o risco de generalizar e caracterizar uma dada categoria de pessoas com base numa posição particular no seu interior, obscurecendo as dinâmicas de marginalização interseccional. Mobilizando uma perspetiva de género, importa sobretudo refletir sobre as intersecções de várias formas de desigualdade, que tanto sugerem possíveis direções para futuras investigações sobre as desigualdades e a pandemia como evidenciam a 
necessidade de melhorar e expandir o sistema de recolha de indicadores sobre os efeitos da crise pandémica. Um dos grandes obstáculos com que nos deparamos é, antes de mais, a escassez de informação desagregada que permita identificar quem mais sofre os efeitos do descalabro social e económico desta crise. Precisamos de saber mais sobre intersecções que, além do género, incluam elementos como deficiência, identidade de género, orientação sexual, classe, nacionalidade, estatuto migratório, religião.

A desagregação de indicadores que permitam analisar detalhadamente o impacto de género da pandemia concorda com uma operacionalização da desigualdade como múltipla e interconectada. A proposta feminista da intereseccionalidade (veja-se Hill Collins, 2019) não se encontra distante de outras abordagens teóricas, como a de Göran Therborn, que mobilizando uma definição multidimensional, entende a desigualdade como uma "desigualdade existencial das capacidades ou dos graus de liberdade atribuídos às pessoas" (Therborn, 2013: 49). O conceito multidimensional de desigualdade existencial permite abranger várias manifestações da desigualdade: as mulheres oprimidas pelo patriarcado e o sexismo, os imigrantes e as minorias étnicas, as pessoas com deficiências, os homossexuais ameaçados pela intolerância, os ocupantes dos escalões mais baixos da maioria das hierarquias. Os exemplos abundam e grande parte deles são experienciados e vividos no feminino. Todos se referem a atribuições desiguais de autonomia pessoal, reconhecimento e respeito, a negações de uma igualdade existencial das pessoas humanas. Neste sentido, a desigualdade existencial está patente na perda de autonomia das mulheres afetadas pelo desemprego e a pobreza, no enclausuramento das populações migrantes em bairros estigmatizados e com falta de condições sanitárias, bem como na exclusão mais acentuada de pessoas homossexuais e transgénero, como relevam as tendências da crise. A verdade é que os arranjos institucionais que temos não conseguem travar $\circ$ agudizar da penalização a quem já se encontrava em posições de menor autonomia existencial, para parafrasear Therborn, ou em posição de inferioridade 
num regime de género que continua a beneficiar quem se encontra em posições de maior poder económico e social. Mau grado as diferenças que também dividem o grupo dos homens em diversas posições de privilégio e subalternidade, continuam a ser eles, habitualmente brancos, heterossexuais e de classe média/alta, quem menos sofre o impacto da crise.

pressuposto de que os padrões de desigualdade de género são co-construídos por diferentes regimes, múltiplos e relativamente autónomos, cada um com a sua forma específica de desigualdade institucionalizada, foi bem desenvolvido por Raewyn Connell (1987). Cada regime de género - Poder, Produção, Emoções, Simbólico - é, na verdade, um regime de desigualdade interseccional (Walby, 2020). Cada regime tem uma dinâmica própria, ainda que se articule com os restantes regimes que compõem a ordem de género, ela própria uma ordem de desigualdade organizada em função da hierarquização gerada por princípios impostos pela classe social, a racialidade e a orientação sexual. A maior ou menor subalternidade de um indivíduo dependeria da sua posição nessa mesma ordem, constituída por regimes desiguais e uma hierarquia de posições, inspirada na teoria de Gramsci sobre a hegemonia. Afinal, a masculinidade é hegemónica porque impõe, mesmo com contradições e diferenças internas, a cada regime em particular, a sua dominância sobre o feminino e todas as formas subalternas de ser homem e de ser pessoa humana.

A teoria multidimensional de Connell e a sua mobilização do conceito de hegemonia é particularmente útil por duas razões. Em primeiro lugar, permite observar posições ocupadas numa realidade que é material e estrutural a partir de uma lente de género. A teoria da interseccionalidade, por seu lado, apega-se mais a categorias de identidade que, ainda que importantes, podem limitar a observação dos processos de desigualdade de género de carácter exógeno, como aqueles que abruptamente são despoletados por crises profundas. As contradições institucionais e estruturais necessitam de ser analisadas e criticadas. Em segundo lugar, a utilização que Connell faz do conceito de hegemonia e a sua teorização da masculinidade hegemónica 
permite-nos encontrar pistas para explicar por que razão ainda hoje as crises sanitárias (ou outras) têm efeitos imediatos sobre as mulheres e as minorias em geral. Seguindo Connell, diríamos que os elementos patriarcais, por vezes ocultos por detrás de discursos inclusivos e igualitários, ganham ascendência suficiente para impor mais claramente a hegemonia de um certo perfil de homem (branco, de classe média/ alta, heterossexual).

As mudanças operadas em cada regime institucional de género, da casa e da família ao emprego e à rua, foram ainda insuficientes para alterar este cenário, que ganha contornos mais claros em tempos de crise. Mais ainda, as crises visibilizam o regime de violência de que se constituem as relações de género. As crises, e a Covid-19 não constitui exceção, viabilizam a expansão de forças regressivas ao mesmo tempo que alimentam reações virulentas de proteção de poderes ameaçados, como sucede com os populismos de direita ou os grupos de defesa da masculinidade tradicional.

É possível que venhamos a assistir a retrocessos em matéria de igualdade de género. Habitualmente, períodos conturbados fomentam a proliferação de discursos sobre os efeitos da crise. $\bigcirc$ campo do género não é diferente. Antes pelo contrário. Tem sido terreno fértil para discursos sobre a crise da masculinidade, que tendem a suceder-se no tempo e podem ser facilmente rastreados até ao século XVII, quando o termo "masculinidade" começou a ser usado para qualificar as "qualidades apropriadas do sexo masculino como másculo, viril, poderoso." Recorrendo a um exemplo do final do século XIX apontado pelo historiador Christopher E. Forth (2008), podemos ver como durante o período de expansão colonial dos impérios ocidentais emergiram discursos sobre uma alegada crise fomentada pelo medo da diferença e da perda de poder masculino, um medo da degeneração. Esse medo abriu caminho para um intenso processo de remasculinização. A solução de então passou por promover o valor da violência na preservação da virilidade. A lição chave neste exemplo é que as noções de crise facilmente se associam ao género e à masculinidade e, como 
prova a história, em diferentes momentos e por diferentes razões, tenderam a propiciar aumentos de violência e desigualdade.

\section{Crise e contradição}

Sem dúvida, parece que voltamos sempre à mesma situação. No entanto, existem interpretações mais benignas e otimistas da crise pandémica, enquanto oportunidade de construção de maior igualdade, incluindo, claro está, as relações de género (Wenham et al., 2020c). Olhando para o passado, sabemos que as pandemias mudaram, ou ajudaram a mudar, a história. Desta vez talvez não seja diferente. Talvez assistamos ao que Walter Scheidel chama de "grande nivelamento". Para Scheidel (2018: 6), o nivelamento profundo e duradouro da desigualdade de riqueza dependeu, ao longo da história humana, do curso de ação imposto por pelo menos um dos "Quatro Cavaleiros" (expressão que usa como alegoria do apocalipse) do nivelamento, a saber: a guerra de mobilização de massas; as revoluções transformadoras (como o comunismo); o colapso do Estado; e, finalmente, os episódios de peste e pandemia. Se a tese de Scheidel estiver correta, poderemos almejar a mudanças também na desigualdade de género. O tempo dirá que futuro pós-pandemia nos está reservado. Por enquanto, importante, contudo, é identificar e mitigar os efeitos danosos da pandemia.

Sem dúvida, a crise sanitária acentua as desigualdades. E acentua também as contradições que organizam a nossa ordem de género. A primeira dessas contradições está hiper-diagnosticada e continua a afetar muitíssimo as mulheres. Presas a diferentes regimes de género, como o são a vida doméstica da família e as obrigações do trabalho pago, as mulheres parecem sistematicamente enfrentar os desafios das contradições sistémicas da ordem de género. Lembrando o conceito de 
lugar contraditório de classe de Erik Olin Wright (1983), ${ }^{2}$ o género também padece de contradições, implicando não uma posição (por exemplo, derivada a partir do sexo biológico), mas um conjunto interconectado de posições em diferentes regimes institucionais, cada um definido por regras e modos de funcionamento diversos. A sobrecarga das mulheres, assoberbadas com uma dupla jornada de trabalho e responsabilidades que a pandemia veio agudizar, permanece profundamente enraizada nas sociedades contemporâneas porque não conseguimos resolver as contradições associadas ao género, como regime de diferença, desigualdade e violência.

É preciso notar que longe de imaginários conservadores e patriarcais, as mulheres estão na linha da frente da luta contra o vírus. Afinal, a maioria dos profissionais de saúde são mulheres: na União Europeia, 4 em cada 5. Na verdade, segundo dados do Eurostat, em 2019, dos quinze milhões de trabalhadores da saúde, 78\% eram mulheres, e mais de um terço do total (36\%) tinha mais de 50 anos. Porém, mau grado o papel fundamental exercido pelas mulheres nesta área vital, continuam a ser elas quem assume a maioria das tarefas domésticas e dos cuidados com os filhos. São elas também quem mais perde em termos laborais e enfrenta maiores dificuldades de conciliação. Finalmente, continuam a ser elas as principais vítimas de violência no cenário doméstico, tendência acentuada pelo confinamento.

Quando operamos com uma perspetiva interseccional atenta às posições estruturalmente contraditórias no seio da ordem de género,

\footnotetext{
2 Erik Olin Wright argumentava que em cada modo de produção certas classes sociais são definidas ao serem completamente polarizadas dentro das relações sociais de produção relevantes. No entanto, na ausência de polarização, surgem também locais contraditórios dentro de um modo de produção. Por exemplo, os gestores têm interesses contraditórios enquanto classe: tal como os trabalhadores, são explorados pelos capitalistas (que lucram com o trabalho de gestão), mas, tal como os próprios capitalistas, dominam e controlam os trabalhadores. Além disso, as formações sociais concretas raramente compreendem um único modo de produção, de modo que as sociedades capitalistas, por exemplo, normalmente contêm certas formas não capitalistas de relações de produção.
} 
conseguimos perceber ainda melhor quem mais sofre com a pandemia. Conseguimos sobretudo perceber as limitações das normas de igualdade e inclusão, que construídas sobre as promessas das políticas de reconhecimento, vão cedendo à dura realidade imposta pelos constrangimentos económicos e sociais.

Notas finais: sobre os limites do reconhecimento e os regimes interseccionais da desigualdade de género

As lutas pelo reconhecimento têm sido fundamentais pelo menos desde a década de 1990, sendo difícil, senão impossível, imaginar a igualdade e a inclusão de género fora do escopo político do reconhecimento de que cada um tem inalienável direito a expressar e legitimar a sua identidade. Sem a linguagem do reconhecimento, as reivindicações de vários movimentos sociais, desde os movimentos feministas e LBGTIQ+ às lutas de minorias étnicas e raciais ou religiosas, não teriam produzido os efeitos que hoje conhecemos, ainda que parcial e muito aquém de qualquer noção de justiça de género. Os feminismos negros e a luta do Black Lives Matter que marcam a agenda contemporânea mostram bem, no entanto, a iniquidade que atinge com mais força as pessoas e as mulheres pertencentes a grupos marginalizados. Através destas lutas, ganhámos também familiaridade com a linguagem analítica da interseccionalidade que nos mostra que a mobilização política de um dado grupo, como as mulheres ou as minorias sexuais e de género, tenderá a deixar para trás as experiências de quem é mais marginalizado.

Os modelos de prevenção contra a Covid-19 não tiveram, aliás, em real consideração a desigualdade de condições e posições, ajustando-se à vida de indivíduos e famílias com habitações confortáveis e espaçosas, acesso a recursos materiais e bons conhecimentos do universo digital, seja para as crianças seja para as mães e pais em regime de teletrabalho. Estes modelos de prevenção de classe média, que, em razão de facilidades de acesso online, são, na verdade, aqueles até agora mais estudados e escrutinados pelas 
ciências sociais, como verificamos analisando as características sociodemográficas das amostras inquiridas e entrevistadas, comportam uma elevada desigualdade de género. Essa desigualdade será tanto mais grave quanto maiores as dificuldades e marginalizações enfrentadas pelas pessoas, mulheres, homens ou pessoas trans e não-binárias. Para segmentos mais empobrecidos, os quartos com casa de banho privada onde o familiar infetado convalesce não abundarão, as possibilidades de teletrabalho não existem e os telemóveis e computadores portáteis com ligação segura à internet estarão em falta. Com efeito, a desigualdade das famílias face à educação das crianças é gritante. De acordo com dados do Instituto Nacional de Estatística, divulgados em novembro de 2019,3 cerca de 5,5\% dos agregados familiares com crianças até aos 15 anos afirmavam não ter acesso à internet em casa. Mais, um quarto dos alunos do $1 .^{\circ}$ ciclo da rede escolar pública de Lisboa não tem meios digitais para estudar em casa.

A par do reconhecimento do direito à identidade e à diferença, a redistribuição de recursos materiais é assim prioritária. Como bem alertou Nancy Fraser, o modelo de reconhecimento identitário que tem sido dominante não consegue resolver o problema da falha da redistribuição. Esta falha tornou-se ainda mais patente na pandemia. À medida que os recursos faltam e a precariedade das condições materiais de existência se agrava, imediatamente se agravam também todas as outras desigualdades. Neste sentido, a lupa gigante com que de momento somos forçados a olhar para as desigualdades permitir-nos-á entender mais profundamente as conexões, por vezes ocultas, entre diferentes formas de desigualdade e deslindar, no interior da ordem de género, quais as interligações entre diferentes regimes de género. Sem esse olhar interseccional teremos dificuldade em entender que existe uma ordem de desigualdade feita de intersecções múltiplas entre posições de vulnerabilidade. No campo do género, como em outros, o reconhecimento, por si só, não é suficiente. Ou não seriam

\footnotetext{
${ }^{3}$ Ver aqui.
} 
mais uma vez os grupos expectáveis a ser os mais punidos pela pandemia. O grande desafio é reverter esta tendência de vez.

\section{Referências bibliográficas}

Amador, Susana (2020), O vírus da desigualdade de género, Público, 28 agosto 2020.

Barata, Catarina; Dulce Morgado Neves; e Mário JDS Santos (2020), COVID-19 Containment Measures, Perinatal Experiences, and the Fight for Childbirth Rights in Portugal, Medical Anthropology Quarterly. International Journal for the Analysis of Health.

Bayefsky, Michelle J.; Deborah Bartz; e Katie L. Watson (2020), Abortion during the Covid-19 Pandemic - Ensuring Access to an Essential Health Service, New England Journal of Medicine, 382/19: e47.

Bowleg, Lisa (2020), We're not all in this together: on COVID-19, intersectionality, and structural inequality, American Journal of Public Health, 110 (7), pp.917-918.

Cerqueira, Carla (2020), Desigualdades de género em tempos de pandemia, Communitas Think Tank-Ideias.

Connell, Raewyn W. (1987), Gender and Power: Society, the Person and Sexual Politics, Cambridge, Polity.

Diniz, Debora (2017), Zika em Alagoas: a urgência dos direitos, Brasília, Letras Livres.

Escola Nacional de Saúde Pública (2020), "Opinião Social", Que condições têm os portugueses em teletrabalho?, Barómetro Covid-19.

Expresso (2020), Covid-19. Quase 90\% dos empregos destruídos eram de Mulheres, 15 junho 2020.

Forth, Christopher E. (2008), Masculinity in the Modern West: gender, civilization and the body, New York and Basingstoke, Palgrave.

Fraser, Nancy; e Axel Honneth (2003), Redistribution or Recognition? A politicalphilosophical exchange, Londres, Verso. 
Georgieva, Kristalina; Stefania Fabrizio; Gheng Hoon Lim; e Marina M. Tavares (2020), A COVID-19 e as diferenças de gênero, FMI.

Hill Collins, Patricia (2019) Intersectionality as Critical Social Theory, Durham, Duke University Press.

Human Rights Watch (2017), Esquecidas e desprotegidas. O impacto do vírus Zika nas meninas e mulheres no nordeste do Brasil.

Kim, Eunji; e Shawn Patterson (2020), The Pandemic and Gender Inequality in Academia.

Magalhães, Pedro; Rita Gouveia; Rui Costa Lopes; e Pedro Adão e Silva (2020), O Impacto Social da Pandemia. Estudo ICS/ISCTE Covid-19. Abril 2020.

Nunes, João (2019), The everyday political economy of health: Community health workers and the response to the 2015 Zika outbreak in Brazil, Review of International Political Economy.

Público (2020), Covid-19. Pandemia agudizou situações de violência doméstica já existentes, 16 junho 2020.

Santos, Márcia Pereira Alves dos; Joilda Silva Nery; Emanuelle Freitas Goes; Alexandre da Silva; Andreia Beatriz Silva dos Santos; Luís Eduardo Batista; e Edna Maria de Araújo (2020), População negra e Covid-19: reflexões sobre racismo e saúde, Estudos Avançados, 34 (99), pp. 225-244.

Scheidel, Walter (2018), The Great Leveler: Violence and the History of Inequality from the Stone Age to the Twenty-First Century, Princeton, Princeton University Press.

Silva, Pedro Adão; Renato Miguel do Carmo; Frederico Cantante; Catarina Cruz; Pedro Estevão; Luís Manso; e Tiago Santos Pereira (2020), Trabalho e desigualdades no Grande Confinamento (Estudos CoLABOR, N. ${ }^{\circ} 2 / 2020$ ), COLABOR.

Therborn, Göran (2013), The Killing Fields of Inequality, Cambridge, Polity Press.

UNWomen (2020), The Shadow Pandemic: Violence against women during COVID-19.

Walby, Sylvia (2020), Varieties of Gender Regimes. Social Politics, Fall 2020, pp. 414-431. 
Watkins-Hayes, Celeste (2014), Intersectionality and the Sociology of HIV/AIDS: Past, Present, and Future Research Directions, Annual Review of Sociology 40, pp. 431-457.

Wenham, Clare; Julia Smith; e Rosemary Morgan (2020a), COVID-19: the gendered impacts of the outbreak, Lancet, 395 (10227), pp. 846-848.

Wenham, Clare; Julia Smith; Sara E. Davies; Huiyun Feng; Karen A. Grépin; Sophie Harman; Asha Herten-Crabb; e Rosemary Morgan (2020b), Women are most affected by pandemics - lessons from past outbreaks, Nature, 583, pp. 194-202.

Wenham, Clare; Julia Smith; Rosemary Morgan (2020c), Covid-19 is an opportunity for gender equality within the workplace and at home, BMJ (online), 369:m1546.

Wright, Erik Olin (1983), 'Class boundaries and contradictory class locations', em A. Giddens and D. Held (eds), Classes, Power, and Conflict - Classical and Contemporary Debates, California, University of California Press, pp. 112-129. 
Entrevista realizada a Sofia Aboim no âmbito da rubrica "Um olhar sociológico sobre a crise Covid-19", publicada a 21 de abril de 2020.

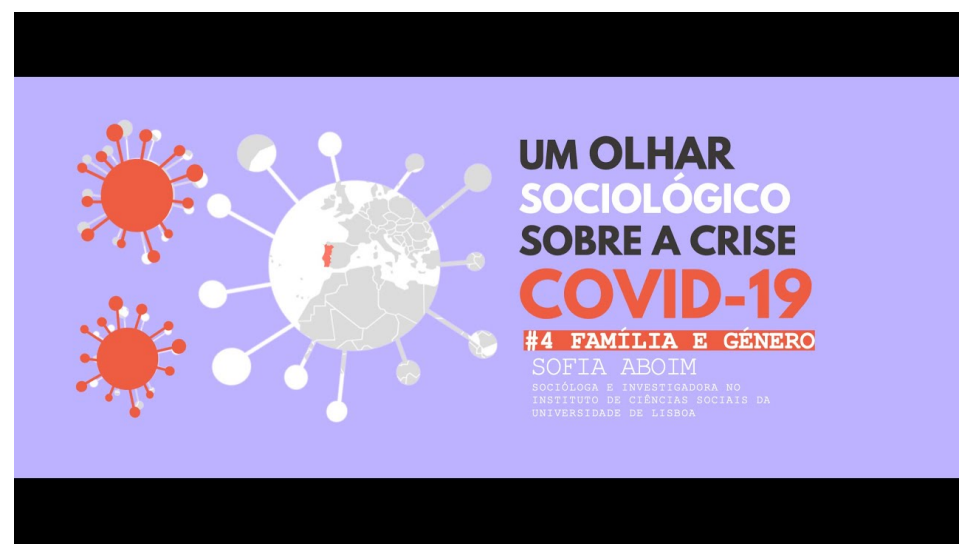




\section{CAPÍTULO 10}

O IMPACTO DA COVID-19 NA VIOLÊNCIA NAS RELAÇÕES DE INTIMIDADE: PISTAS PARA REFLEXÃO

\section{Madalena Duarte}

Professora Auxiliar da Faculdade de Economia da Universidade de Coimbra, Investigadora do Centro de Estudos Sociais

\section{Introdução}

Os contextos de crise - seja económica, ambiental, política e/ou de saúde pública - tendem a potenciar cenários de agudização de múltiplas violências, entre as quais a violência de género. A pandemia causada pela Covid-19 parece não ser exceção, impondo-se uma reflexão sobre os seus impactos nas violências de género e nos grupos com uma maior incidência de vitimação, em particular mulheres, crianças e pessoas LGBTIQ+. Mas esta análise deve ter presente que a pandemia não criou, per se, situações de violência de género. Os números conhecidos destas violências eram já preocupantes, falando mesmo alguns/mas autores/as em dupla pandemia (Bettinger-Lopez e Bro, 2020). A insegurança relativamente ao futuro, assim como a instabilidade e a precariedade que marcam logo no presente estes contextos, contribuem para que grupos sociais já vulneráveis se encontrem ainda mais desprotegidos. A crise pandémica atual evidencia, pois, que o cruzamento entre um cenário estrutural, produzido pelo patriarcado e marcado pela desigualdade de género, e um contexto ocasional, mas de emergência, provocado pelo vírus, pode intensificar as situações de abuso quer para vítimas de violência de longo-termo, quer para aquelas que apenas mais recentemente começaram a sofrer abuso.

$\mathrm{Na}$ altura em que escrevo este texto, estamos ainda a viver a crise pandémica, pelo que é prematura uma análise sociológica objetiva sobre os seus impactos nas violências de género. Podemos, apesar do 
imediatismo, refletir sobre algumas evidências e, tendo em conta o que a história nos tem dado a conhecer, sobre ausências que persistem.

Para esta reflexão há duas notas prévias que devem ser consideradas. Em primeiro lugar, o meu foco será na violência nas relações de intimidade. Na sequência das medidas de confinamento social impostas por diferentes governos em todo o mundo (em alguns locais e momentos com carácter coercivo), houve um aumento significativo de casos registados pelos órgãos de polícia criminal e organizações estatais e da sociedade em países social e culturalmente tão diversos como a China, Austrália, França, Alemanha, EUA, África do Sul ou Brasil (UN Women, 2020). Portugal não foi exceção. ${ }^{1}$ O alarme social causado pelo aumento das denúncias possibilitou, por um lado, o reforço de medidas destinadas a mitigar as consequências da pandemia nas vítimas (na sua maioria mulheres); mas, por outro lado, poderá ter contribuído para a invisibilização de outras violências de género. Este ensaio não colmata essa insuficiência analítica. Em segundo lugar, se o aumento de casos de violência nas relações de intimidade se verificou um pouco por todo o mundo, é necessário ter em atenção que estes processos são diversos tendo em conta as especificidades sociais, culturais, históricas e políticas dos diferentes países e, também, a importância dada pelo poder político a este tipo de violência e o seu enquadramento jurídico normativo.

"Fica em casa": o lar como espaço de segurança

Como forma de conter a propagação do vírus, a maioria dos governos apelou ao distanciamento social, sendo o confinamento uma medida de exceção imposta em vários países. A mensagem "fica em casa"

1 Como anunciado aos meios de comunicação social pela Secretária de Estado para a Cidadania e a Igualdade, em junho de 2020, entre 19 de março e 15 de junho houve um aumento de cerca de $180 \%$ dos pedidos de ajuda de vítimas em situação de violência doméstica para a linha de apoio da Comissão para a Cidadania e a Igualdade de Género face ao primeiro trimestre de 2019. Ver aqui. 
rapidamente se disseminou, contrapondo a insegurança do espaço público, marcado pela propagação do vírus, com a proteção pessoal oferecida pelo lar. No entanto, a violência nas relações de intimidade evidencia que as geografias sociais do medo das mulheres são muitas vezes deslocadas do espaço público para o espaço privado, onde a violência corrompe o conceito de intimidade. Como elucida a análise histórico-jurídica de Reva Siegel (1996), a perda de legitimidade do direito a bater na mulher, dominante até ao século XIX, foi substituída progressivamente pela afirmação do direito à privacidade, emergindo a intimidade afetiva como uma retórica adequada para legitimar a impunidade da violência nos tempos modernos. É necessário desconstruir este imaginário do "lar", disseminado já no Estado Novo, e olhar com particular atenção para os espaços de domesticidade, sobretudo quando também se pressupõe que o agressor está em confinamento.

A violência nas relações de intimidade é uma realidade dinâmica, heterogénea, que se expressa de múltiplas formas - ao nível físico, sexual, psicológico, económico, de discriminação sociocultural, malestar social, insegurança e medo - e que pode ser mais ou menos prolongada no tempo, combinando vários atos de violência. Todas estas formas de exercício da violência podem ser mais frequentes e severas num contexto de confinamento social. Como demonstram as estatísticas², a violência de género tende a agudizar-se após longos períodos de convivência familiar, como no final das férias de verão ou de natal, ocorrendo muitos dos assassinatos a mulheres precisamente no final destes períodos. $O$ contexto de isolamento social provocado por esta pandemia, em particular aquando do Estado de Emergência, propiciou um desses momentos de convivência prolongada entre agressor e vítima, com a agravante de ser marcado por stress emocional e por ansiedade provocados pela incerteza relativamente ao presente e ao futuro e, em muitos casos, pela instabilidade financeira. Desde logo, o confinamento possibilita um maior controlo do agressor sobre a

\footnotetext{
2 Ver aqui.
} 
vítima, os seus movimentos e o seu trabalho, o que, consequentemente, reforça a já existente assimetria de poder entre agressor e vítima e afeta a saúde física e mental da vítima. Depois, não só permite o agravamento, como já se referiu, de formas de violência já existentes, como também abre espaço para novas formas de controlo, abuso e manipulação. Por exemplo, ameaçar expor a vítima e os seus dependentes a cenários em que haja um maior risco de contaminação com o vírus. As imposições normativas dos papéis de género podem, de facto, fazer com que os homens exibam comportamentos de segurança despiciendos, expondo-se a si e às suas famílias mais facilmente ao vírus, aumentando o medo e insegurança. Este é um contexto igualmente propício, sobretudo para as mulheres vítimas de violência numa relação de namoro, à ciberviolência.

As próprias estratégias de sobrevivência e resiliência quotidianas desenvolvidas pelas vítimas para sua própria proteção, mas também dos seus dependentes, em particular crianças, pode estar condicionada. As vítimas, mesmo em situação de necessidade, podem não se deslocar a nenhuma unidade de saúde pelo medo de serem contaminadas, o que pode colocar em causa inclusive a sua saúde sexual e reprodutiva e, consequentemente, reforçar a posição de poder do agressor (Lokot e Avakyan, 2020). O isolamento não só fragiliza as redes familiares e de amizade, como também constrange 0 acesso às redes de apoio institucionais, necessariamente com menos recursos humanos e menos serviços presenciais. Por tudo isto, as medidas de confinamento que surgiram na sequência da pandemia parecem ter criado, na opinião de alguns/mas peritos/as, uma "tempestade perfeita" no que diz respeito à violência nas relações de intimidade (Bettinger-Lopez e Bro, 2020).

Obviamente que tal não significa que a violência no espaço público tenha diminuído com o confinamento. $\bigcirc$ apelo ao distanciamento social, o incentivo ao teletrabalho e as medidas de emergência que encerraram muitos serviços e comércio contribuíram para o esvaziamento das ruas, tornando os espaços urbanos e rurais mais propícios à violência (em particular sexual) contra as mulheres mais vulneráveis (como as sem abrigo) ou aquelas que trabalham nos 
serviços essenciais, como a enfermagem e a assistência social, altamente feminizados.

Assim, para muitas pessoas, em particular mulheres e crianças, o apelo ao confinamento social para proteção do bem comum, aqui entendido como saúde pública, significou uma perda (ainda mais) significativa da sua qualidade de vida individual.

Os efeitos da pandemia na esfera económica

Uma análise dos impactos da Covid-19 na violência de género não pode ser restrita ao curto prazo. A pandemia e as medidas implementadas para conter a propagação do vírus têm já consequências visíveis na esfera económica e no mercado de trabalho, estimando-se que a médio e longo prazo aumente a precariedade, o desemprego, a desregulação e, consequentemente, a pobreza e a exclusão social. A crise económica e financeira de 2008 mostrou-nos, claramente, que estas consequências têm profundos impactos na desigualdade de género (Alcañiz et al., 2015; Ferreira e Monteiro, 2015; Ribeiro et al., 2015) e o mesmo se antecipa relativamente à presente pandemia. Como nos dizem Lopes e Coelho, "a informação sobre a evolução socioeconómica mostra que o afastamento forçado do local de trabalho, o desemprego e a perda de rendimento estão a afetar desproporcionalmente as mulheres" (2020: 43). Para as mulheres, o contexto de pandemia vem reforçar um contexto socioeconómico já marcado pela precariedade, pela elevada exigência de conciliação da vida familiar com a vida profissional, por uma sociedade-providência com um rosto marcadamente feminino, por uma valorização e um reconhecimento desiguais de mulheres e de homens, por uma distribuição estereotipada e assimétrica dos papéis, tarefas e funções masculinas e femininas. Acresce que o facto de a área da saúde e do serviço social ser maioritariamente ocupada por mulheres exigiu destas uma pressão adicional no desempenho das suas tarefas e, possivelmente, uma maior negligência com as suas necessidades pessoais. 
A violência nas relações de intimidade - apesar de estar associada à esfera privada - tem múltiplas interferências e consequências no trabalho da vítima, com custos (económicos e pessoais) elevadíssimos (Duarte et al., 2019). A violência provoca perdas de produtividade consideráveis, absentismo laboral, causa danos na carreira profissional da vítima e pode levar à perda do seu emprego (idem). Num contexto de pandemia, estas consequências podem ser mais imediatas. Por exemplo, o agressor mais facilmente controla e prejudica a produtividade da vítima se esta estiver em regime de teletrabalho. Os contextos de precariedade e fragilização económica das famílias são também menos propícios a que as vítimas procurem ajuda ou denunciem práticas abusivas. Em suma, a violência nas relações de intimidade enfraquece a posição da vítima no mercado de trabalho, posição já por si muito vulnerável. A violência contribui efetivamente para a vulnerabilização social, económica, cultural e política de muitas mulheres e, por sua vez, essa vulnerabilização concede a manutenção do abuso. Deste modo, qualquer política de apoio às vítimas de violência de género no atual contexto deve ter em conta a situação económica das mulheres pré e pós pandemia, a sua posição no mercado de trabalho, o seu lugar central em serviços e cuidado (determinantes nesta crise pandémica) e a conciliação entre a esfera profissional e familiar.

"Estamos todos juntos": um (necessário) olhar interseccional

A gestão da crise pandémica tem passado pelo apelo a uma responsabilidade coletiva bem traduzida na mediática mensagem "estamos todos juntos". É certo que o vírus pode contaminar qualquer pessoa, mas a mensagem "estamos todos juntos" assenta num pressuposto errado: a homogeneização das condições de todos e todas nós, como se fossemos iguais antes da pandemia e perante a pandemia. Como escrevia recentemente Paul B. Preciado (2020) refletindo sobre o conceito de biopolítica de Michel Foucault e sobre a ligação entre comunidade e imunidade sugerida por Roberto Esposito 
-, a gestão política das epidemias tende a criar uma utopia de comunidade. Esta comunidade comporta deveres, mas também privilégios; é inclusiva, mas reproduz e intensifica ativamente os processos de marginalização de diversos grupos sociais. $\bigcirc$ conceito de interseccionalidade (Crenshaw, 1991) é útil neste ponto, na medida em que traz desassossego à ideia de um "nós" e de um "todo" coletivo ao enfatizar o carácter permanente da desigualdade e injustiça social que afetam determinados grupos. A breve reflexão encetada até agora já nos mostrou que um desses grupos sociais é constituído pelas vítimas de violência nas relações de intimidade, em particular mulheres. Mas mesmo dentro deste grupo há diferenciações que devem ser tidas em conta (historicamente, o conceito de interseccionalidade procurou mostrar isso mesmo nos feminismos). As mulheres vítimas de violência experienciam, simultaneamente, diferentes formas de opressão e de controlo social, uma vez que estão imersas em contextos sociais onde o patriarcado se cruza com outros sistemas de poder que as fragiliza, como o colonialismo e o capitalismo. A Covid-19, tal como a violência de género, é transversal a todas as mulheres, mas há desigualdades estruturais que podem agravar os seus impactos e, do mesmo modo, conceder diferentes níveis de acesso aos serviços e recursos disponíveis de combate e proteção.

A pandemia atual tem-se revelado particularmente grave para as mulheres mais velhas e de classes sociais mais baixas. Mas também as mulheres imigrantes, refugiadas, racializadas, de minorias étnicas e culturais, transgéneros, de orientações sexuais não normativas, com deficiência, entre muitas outras, se encontram mais nas margens da sociedade e sujeitas a violências múltiplas que extravasam a esfera íntima (mas que nela interferem) e que não podem ser invisibilizadas. Se tal é preocupante em contextos de paz social, política e económica, é-o ainda mais numa altura como a que vivemos presentemente, na qual estas mulheres se podem encontrar mais isoladas e sem redes de apoio informal. 
"Vai ficar tudo bem": a exceção como normalidade

Boaventura de Sousa Santos (2020) diz-nos que esta pandemia nos permite ver a "normalidade como exceção". A violência de género, e em particular a violência nas relações de intimidade, é paradigmática da banalização de um estado que devia ser de exceção. $O$ autor olha para as crises globais, nomeadamente para a crise financeira, de modo a explicar que o que devia ser percebido como passageiro transforma-se em permanente, relativizando-se as soluções porque também não se questionam mais as causas. Ora, se é certo que o vírus proporcionou uma maior atenção mediática para com a violência nas relações de intimidade, o patriarcado não saiu enfraquecido, porque em momento algum foi questionado. Nesta esteira, será que as medidas que, em bom tempo, foram desenvolvidas e implementadas em diversos países (e.g. aumento das campanhas de prevenção em diversos locais, adaptação das estruturas de atendimento e acolhimento às vítimas, reforço das respostas institucionais, etc.), sobretudo a partir do segundo trimestre de 2020, são respostas realmente capacitantes e transformadoras?

Para as vítimas de violência numa relação de intimidade, o final da pandemia não permite o regresso a uma normalidade que possamos aceitar enquanto sociedade. A concretização da ideia mais disseminada e romantizada desta crise - "vai ficar tudo bem" - depende também da nossa atenção e atuação relativamente às condições e processos que contribuem para a vulnerabilização quotidiana destas mulheres e da nossa luta, enquanto cidadãos/ãs e cientistas sociais por políticas de dignidade, cidadania e reconhecimento.

Referências bibliográficas

Alcañiz, Mercedes; Vicent Querol; e Ana Marti (2015), "Las mujeres jóvenes en

España. (Nuevas) precariedades y (viejas) desigualdades", Revista ex aequo "Dossier: Austeridade e Regimes de Bem-estar e de Sexo/Género", 32, pp. 117-137. 
Bettinger-Lopez, Caroline; e Alexandra Bro (2020), "A Double Pandemic: Domestic Violence in the Age of COVID-19", Gender-Based Violence, 3.

Duarte, Madalena (org.), e outros (2019), Prevenção e Combate à violência contra as mulheres e violência doméstica nas entidades empregadoras: guião de boas práticas, Lisboa, CIG.

Ferreira, Virgínia; e Rosa Monteiro (2015), "Austeridade, emprego e regime de bem-estar em Portugal: Em processo de refamilização?", Revista ex aequo "Dossier: Austeridade e Regimes de Bem-estar e de Sexo/Género", 32, pp. 49-67.

Crenshaw, Kimberlé W. (1991), "Mapping the Margins: Intersectionality, Identity Politics, and Violence against Women of Color", Stanford Law Review, 43(6), pp. 1241-1299.

Lokot, Michelle; e Yeva Avakyan (2020), "Intersectionality as alens to the COVID-19 pandemic: implications for sexual and reproductive health indevelopment and humanitarian contexts", Sexual and Reproductive Health Matters".

Lopes, Mónica; e Lina Coelho (2020), "(Des)igualdades entre mulheres e homens", em José Reis (org.), Palavras para lá da pandemia: cem lados de uma crise", Coimbra, CES.

Preciado, Paul B. (2020), "Aprendendo com o vírus".

Ribeiro, Raquel; Lina Coelho; e Alexandra Ferreira-Valente (2015), "Unemployment and gender equality within the family in Portugal", Revista ex aequo "Dossier: Austeridade e Regimes de Bem-estar e de Sexol Género", 32, pp. 69-85.

Santos, Boaventura de Sousa (2020), A Cruel Pedagogia do Vírus, Coimbra, Edições Almedina.

Siegel, Reva B. (1996), "The Rule of Love: Wife Beating as Prerogative and Privacy", Faculty Scholarship Series, Paper 1092.

UN Women (2020), Violence Against Women and Girls: the Shadow Pandemic, United Nations. 
Entrevista realizada a Madalena Duarte no âmbito da rubrica "Um olhar sociológico sobre a crise Covid-19", publicada a 19 de maio de 2020.

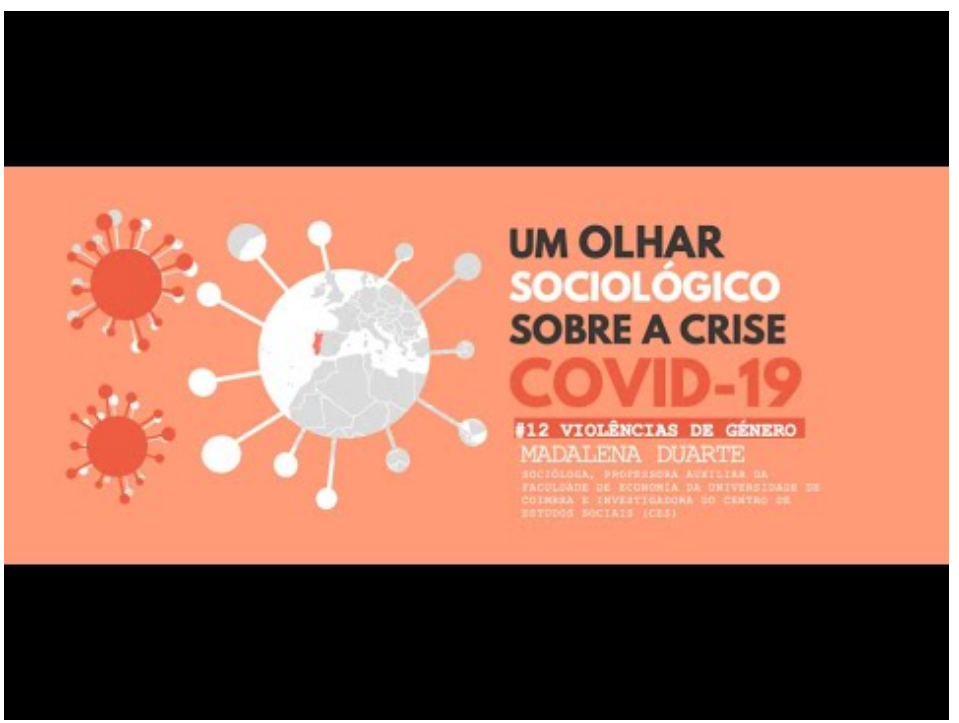




\section{CAPÍTULO 11}

ENVELHECIMENTO NAS COMUNIDADES NO PÓS-COVID-19

\section{Alda Botelho Azevedo}

Investigadora Auxiliar do Instituto de Ciências Sociais da Universidade de Lisboa

\section{Introdução}

Globalmente, no final de setembro de 2020, registam-se mais de 33,5 milhões de casos confirmados de Covid-19 e pouco mais de um milhão de óbitos desde o início da pandemia (World Health Organization, 2020a). No mesmo período, Portugal conta com mais de 75,5 mil casos confirmados e quase 2 mil óbitos mas, apesar dos casos confirmados se distribuírem por todas as idades, é no grupo etário dos 70 e mais anos que se concentra a grande maioria dos óbitos (Direção-Geral da Saúde, 2020). Este grupo etário, em 2019, representa $16 \%$ da população residente em Portugal (Instituto Nacional de Estatística, 2020a). ${ }^{1}$

Depois de, em Maio de 2020, se ter reflectido sobre o envelhecimento na crise Covid-19,2 neste texto, a partir do conhecimento sobre a população com idades avançadas residente em Portugal e sobre os factores estruturais das desigualdades no envelhecimento, antecipa-se que a pandemia poderá vir a reforçar, directa e indirectamente, as preferências das pessoas mais velhas pelo envelhecimento em casa e na comunidade, quando as condições de saúde o permitam.

Ainda que o grau de incerteza sobre o desfecho da pandemia da Covid-19 permaneça elevado e mesmo considerando os efeitos

1 Este texto é financiado com fundos nacionais através da FCT, I.P., no âmbito do Projeto PTDC/GES-URB/28853/2017 (SustainLis: Requalificação Urbana Sustentável e Populações Vulneráveis no Centro Histórico de Lisboa).

2 Ver aqui. 
diferenciados segundo coortes, grupos sociais ou regiões do mundo, esta pandemia tem estimulado o debate sobre em que comunidades queremos envelhecer e exposto as desigualdades no envelhecimento. Isto porque, sendo o envelhecimento individual determinado por diversos factores (biológicos, socioeconómicos, culturais e ambientais), as condições de vida nas idades avançadas são o resultado dos percursos individuais.

Reforço das preferências pelo envelhecimento em casa e na comunidade

Envelhecer em casa e na comunidade, isto é, envelhecer no lugar (do inglês "ageing in place"), refere-se à "possibilidade de as pessoas mais velhas viverem na sua própria casa e comunidade, em segurança, independência e conforto, independentemente da idade, do rendimento ou do nível de autonomia" (World Health Organization, 2015: 36). Quer isto dizer que apoiar o envelhecimento em casa e na comunidade pressupõe a existência de um conjunto de políticas e de respostas sociais, de serviços e de equipamentos.

Já existem, em Portugal, exemplos de boas práticas propícias a envelhecer no lugar (ver Fonseca, 2018). Alguns destes projectos são relacionados com o ambiente físico, nomeadamente os que incidem sobre a melhoria das condições habitacionais e dos espaços públicos. Outros estão no âmbito dos serviços como o apoio domiciliário, a provisão de bens de primeira necessidade e o transporte. Outros ainda inserem-se na esfera social, principalmente da inclusão e da participação, como os projectos dirigidos ao combate ao isolamento e à participação na comunidade.

Contudo, a distribuição destas iniciativas é territorialmente dispersa e assimétrica, o que significa que, em primeiro lugar, muitas das pessoas mais velhas residentes em Portugal permanecem sem respostas orientadas para a promoção do envelhecimento em casa e na comunidade. Em segundo lugar, as pessoas que beneficiam dos projectos implementados na área de residência têm uma melhoria das 
condições favoráveis ao envelhecimento em casa e na comunidade limitada ao âmbito de actuação desses mesmos projectos, logo, de impacto parcial.

Por conseguinte, a referência em Portugal continua a ser o envelhecimento em casa, stricto sensu, com o apoio possível da família, das redes de vizinhança e das respostas sociais existentes na área de residência. Com efeito, de acordo com os Censos 2011, em Portugal, a maioria das pessoas com 65 e mais anos vive em famílias clássicas com um núcleo familiar (66\%). Sozinhas vivem $20 \%$ das pessoas neste grupo etário, em partilha de casa $10 \%$ e, por último, em instituições vivem $4 \%$ (Instituto Nacional de Estatística, 2020b). Factores biológicos e demográficos que interagem no envelhecimento individual, nomeadamente o aumento das limitações de saúde à medida que a idade avança e a vantagem das mulheres relativamente aos homens quanto à esperança de vida, explicam, por um lado, que a proporção de pessoas a viver só e em instituições aumente sobretudo a partir do grupo etário dos 75 e mais anos e, por outro lado, a sobrerepresentação do sexo feminino nas idades avançadas (Azevedo e Baptista, 2014).

Não obstante existir ainda um longo caminho a percorrer até que o envelhecimento em casa e na comunidade, na plena acepção do termo, se generalize em Portugal, as profundas alterações na forma como utilizamos e interagimos nos espaços públicos e privados e as limitações à circulação de pessoas que decorreram da situação de pandemia aceleraram mudanças que contribuem para a criação de condições mais favoráveis ao envelhecimento em casa e na comunidade.

Os serviços de apoio

O início da pandemia em Portugal desencadeou iniciativas, sobretudo da responsabilidade do poder local e do terceiro sector, mas também do sector privado, de prestação de serviços de apoio a grupos vulneráveis, como as pessoas com idades avançadas, que vieram completar as respostas existentes nas comunidades pré-Covid-19. Os 
serviços com maior destaque foram a compra e entrega ao domicílio de bens de primeira necessidade e de medicamentos, e algumas medidas sociais, como a criação de linhas de apoio telefónico e o contacto, presencial ou telefónico, com pessoas em situação de vulnerabilidade.

Sendo a população portuguesa extremamente envelhecida, situação que irá acentuar-se pelo menos nas próximas duas décadas (Moreira et al., 2019), o acesso aos serviços de apoio tem estado dependente de uma distribuição no território desigual e, no caso das iniciativas privadas, do rendimento das pessoas que deles necessitam. A pandemia veio assim precipitar a implementação de medidas que resultaram no alargamento e na diversificação da oferta de serviços de apoio ao envelhecimento que, a perdurarem no período pós-Covid-19, contribuem para ambientes mais favoráveis ao envelhecimento no lugar e na comunidade. Uma cobertura mais generalizada destes serviços permite não só ultrapassar importantes obstáculos à vida independente, como os problemas de mobilidade e os constrangimentos de transporte, mas também operar no combate às desigualdades territoriais e de rendimento no envelhecimento.

Com vista à criação de comunidades mais propícias ao envelhecimento em casa e na comunidade, e no que respeita ao ambiente físico, importaria ainda prever o apoio à adaptação das casas e dos edifícios, por forma a responderem às limitações motoras que decorrem do processo de envelhecimento biológico. Podendo ser ancorado nas disposições do Decreto-Lei n. ${ }^{\circ}$ 163/2006 que "aprova o regime da acessibilidade aos edifícios e estabelecimentos que recebem público, via pública e edifícios habitacionais", esse apoio poderia comparticipar obras realizadas por cidadãos particulares proprietários de alojamentos ou de edifícios destinados à habitação de residência habitual que beneficiassem a acessibilidade por pessoas com mobilidade condicionada. As intervenções comparticipadas poderiam incluir melhorias que incidissem na acessibilidade quer no alojamento quer no edifício como, por exemplo, a instalação de bases de duche e de sanitas acessíveis, a colocação de barras de apoio e de corrimões nas escadas, a instalação de plataformas elevatórias, entre outras. 


\section{O acesso aos cuidados de saúde}

Em resultado da Covid-19, foram adiados ou não foram realizados inúmeros actos médicos como consultas, cirurgias e tratamentos. De referir que, em Portugal, três em cada dez pessoas que se sentiram doentes durante a pandemia não recorreram aos cuidados de saúde, sendo o receio de contágio o principal motivo apontado (Jornal Médico, 2020). Na população com idades avançadas, este afastamento dos cuidados de saúde, seja por iniciativa das unidades de saúde ou dos utentes, é ainda mais alarmante porque o envelhecimento biológico é muitas vezes acompanhado por doenças físicas e mentais que necessitam de cuidados médicos regulares.

No intuito de conter a pandemia em Portugal, a Direção-Geral da Saúde privilegiou a realização de teleconsultas, em detrimento das consultas presenciais, contribuindo para a introdução acelerada de uma modalidade de acesso aos cuidados de saúde com vantagens para as pessoas com idades avançadas, sobretudo as que vivem em casa.

Constituindo a idade um factor de risco, a adesão à telemedicina protege as pessoas mais velhas do risco de contágio que advém da proximidade física com outras pessoas nas unidades de saúde (salas de espera, consultórios, sanitários, etc.). A telemedicina anula ainda os obstáculos colocados pelas necessidades de deslocação às unidades de saúde, com vantagens económicas e logísticas para as pessoas com idades avançadas que dependem de meios de transporte, públicos ou privados, para se deslocarem a uma consulta presencial.

Por último, a coexistência de consultas presenciais e à distância poderá ajudar a ultrapassar alguns dos constrangimentos decorrentes das restrições à presença do acompanhante do utente. Apesar de estar garantida essa possibilidade nas situações em que tal seja imprescindível, existem muitos outros casos em que a presença do acompanhante é necessária ou recomendável para uma maior tranquilidade e confiança do utente em como compreende as indicações médicas. 
A familiarização com a telemedicina abre caminho para comunidades pós-Covid-19 em que os cuidados de saúde possam ser prestados presencialmente ou à distância, consoante as necessidades dos utentes, contribuindo para uma resposta mais eficiente dos serviços de saúde e a optimização dos recursos. A difusão da telemedicina contribui ainda para combater as desigualdades territoriais no acesso aos cuidados de saúde, principalmente relevantes nas áreas remotas do país, onde a distância e a falta de transportes públicos constituem uma barreira no acesso aos cuidados de saúde.

\section{A utilização da internet}

A situação de pandemia contribuiu, por um lado, para a intensificação e diversificação dos usos da internet e, por outro lado, para incentivar novos utilizadores. No início do Estado de Emergência, a Anacom estimou um aumento de aproximadamente 50\% no tráfego das comunicações electrónicas, tendo particular relevância o crescimento do tráfego de voz e de dados por ligação à rede fixa (Anacom, 2020). As limitações às restrições impostas pelo Estado de Emergência levaram à intensificação das chamadas telefónicas e das videochamadas, e ao aumento do comércio electrónico. Num período em que a circulação de pessoas esteve muito condicionada, é ainda de referir a importância da internet para o acesso à cultura e o papel das redes sociais.

A internet confere aos seus utilizadores a possibilidade de se manterem em contacto regular com os familiares e amigos, de fazerem visitas virtuais, de assistirem a eventos culturais e desportivos, de participarem em grupos com interesses comuns, de aprenderem novas competências, entre muitas outras actividades. Nas pessoas mais velhas esta possibilidade é ainda mais relevante porque se coaduna com algumas das limitações motoras que decorrem do processo de envelhecimento biológico, combate o isolamento e a exclusão social, e pode comportar benefícios para o bem-estar e para a saúde mental. Contudo, em 2019, apenas 34\% das pessoas com idades entre os 65 e os 74 anos haviam utilizado a internet no ano anterior (Instituto Nacional 
de Estatística, 2020c), ou seja, a idade faz sobressair desigualdades digitais, sobretudo no acesso e utilização da internet, mas também nos serviços com esta relacionados, por exemplo, nos meios de pagamento electrónico, indispensáveis em compras online.

$\mathrm{Se}$, por um lado, é expectável que, no futuro próximo, a proporção de utilizadores da internet nas gerações mais velhas continue a aumentar, em virtude de gerações mais escolarizadas e de equipamentos e software de utilização cada vez mais amigáveis, por outro lado, as competências digitais, muitas vezes relacionadas com as desigualdades na educação e no rendimento, continuarão a desencorajar alguns utilizadores com idades avançadas. É, por isso, importante facilitar o acesso e a utilização da internet pelas pessoas mais velhas, através de formação concebida à medida das necessidades e dos interesses destes utilizadores, bem como de apoio técnico para a compra de equipamentos adequados e a contratualização de serviços de internet.

\section{As estruturas residenciais para idosos}

O reforço das preferências por envelhecer em casa e na comunidade surge ainda como consequência da gestão da pandemia nas estruturas residenciais para idosos, doravante designadas de lares. De acordo com as declarações da Ministra da Saúde, Marta Temido, numa conferência de imprensa realizada em Agosto de 2020, "existem em Portugal 2.526 lares para idosos nos quais estão institucionalizadas 99.234 pessoas e onde trabalham 60 mil profissionais" (Serviço Nacional de Saúde, 2020).

Quem vive num lar tem frequentemente uma condição de saúde mais complexa sendo, por esse motivo, mais vulnerável a ameaças epidemiológicas. A esta vulnerabilidade acresce um risco de disseminação mais elevado por os lares se tratarem de alojamentos colectivos com ambientes usualmente fechados. É, por isso, fundamental a adopção de medidas preventivas, como a monitorização de sintomas e a testagem periódica de todos os residentes e funcionários, e medidas de contenção, como a identificação de cadeias 
de transmissão perante casos confirmados e meios para garantir o isolamento e o tratamento dos casos confirmados que não requeiram hospitalização (World Health Organization, 2020b).

A teoria revelou-se bem mais simples do que a prática e as notícias sobre a elevada mortalidade relacionada com a Covid-19 entre residentes e funcionários dos lares, um pouco por todo o mundo, não preveniu os surtos em Portugal, que têm atingido lares legais e ilegais, comparticipados pela Segurança Social e privados, de custos baixos e elevados. $\bigcirc$ desconhecimento da doença, a falta de meios, de preparação adequada e também, em alguns casos, a desvalorização do risco resultou na perda de inúmeras vidas. No início de Setembro de 2020, 39\% do total dos óbitos relacionados com a doença dizia respeito a residentes em lares (Costa, 2020), num cenário semelhante ao observado em muitos países (World Health Organization, 2020b). Para uma conotação menos positiva dos lares contribuiu ainda a suspensão das visitas entre 7 de Março e 18 de Maio de 2020, entretanto substituída por rígidas regras que privam os seus residentes do contacto presencial com familiares e amigos, com consequências no bem-estar dos residentes.

Contudo, demonizar os lares é contraproducente porque esta é uma resposta social sem alternativa equivalente na actualidade e porque a sua função será tanto mais importante quanto maior for o número de pessoas em situação de dependência e/ou de elevada vulnerabilidade. A contratação de serviços privados de apoio domiciliário não está ao alcance financeiro da grande maioria das pessoas que poderiam beneficiar desses cuidados. E o Estatuto do Cuidador Informal, aprovado em 2019, encontra-se ainda em fase de implementação de projectos-piloto em 30 municípios do país (Departamento de Prestações e Contribuições, 2020).

A Covid-19 surge num contexto em que as ofertas institucionais dirigidas à população com idades avançadas são cada vez mais diversificadas no que respeita às condições de saúde e níveis de dependência, mas que permanecem assentes em modelos de alojamentos colectivos que precisam de ser repensados. Nesta 
redefinição poderão privilegiar-se estruturas com mais espaços privados e espaços exteriores, distribuídas no território de acordo com a proporção de pessoas com idades avançadas na população residente, por forma a possibilitar o envelhecimento na comunidade de pertença em melhores condições de conforto, de privacidade e de segurança dos residentes.

\section{Notas conclusivas}

A pandemia da Covid-19 fomentou nuns casos a introdução e noutros a consolidação de importantes alterações que contribuem de forma directa para que as pessoas mais velhas tenham mais oportunidades e melhores condições para viverem em famílias clássicas, reforçando as preferências pelo envelhecimento em casa e na comunidade. As restrições à circulação de pessoas, como medida de contenção da pandemia, precipitaram o alargamento e a diversificação dos serviços de apoio domiciliário e das modalidades de acesso aos cuidados de saúde e aceleraram uma transformação digital que, estando já em curso, excluía ainda uma grande parte das pessoas com idades avançadas.

Já a gestão da Covid-19 nos lares tem contribuído para uma quebra na confiança das pessoas com idades avançadas e suas famílias, acabando por reforçar, ainda que indirectamente, as preferências pelo envelhecimento em casa e na comunidade. Porque os lares desempenham um papel fundamental nos cuidados e porque a pandemia veio questionar os modelos de alojamentos colectivos instituídos, é importante redefinir as condições de organização, funcionamento e instalação dos lares com vista a, no futuro, melhor garantir o bem-estar dos residentes e dos funcionários.

Numa retrospectiva dos primeiros seis meses de pandemia, tudo aponta para que as pessoas mais velhas estejam a ser as grandes protagonistas, na medida em que é sobretudo sobre elas que têm recaído os fardos do isolamento forçado e da elevada mortalidade. Não podemos desresponsabilizar-nos deste facto justificando-o com a maior 
vulnerabilidade epidemiológica das pessoas mais velhas comparativamente aos restantes grupos etários. Ter uma idade avançada conjuga-se frequentemente com outros factores de vulnerabilidade, como, por exemplo: ter uma incapacidade, receber rendimentos baixos, ser mulher, ser imigrante laboral, pertencer à comunidade LGBTQl ou a minorias nacionais ou étnicas, religiosas e linguísticas, entre muitos outros. Nas comunidades pós-Covid-19, encontrar os instrumentos de combate às desigualdades no envelhecimento poderá passar por compreender a heterogeneidade das pessoas com idades avançadas enquanto produto de percursos de vida diferenciados e, por conseguinte, das desigualdades nas outras idades.

Referências bibliográficas

Anacom (2020), COVID-19 - Tráfego de comunicações eletrónicas aumenta em cerca de $50 \%$.

Azevedo, Alda Botelho; e Maria Isabel Baptista (2014), A Mortalidade em Portugal, 1950-2011. Em Bandeira, Mário Leston (dir), Dinâmicas Demográficas e Envelhecimento da População Portuguesa (1950-2011): evolução e perspectivas, Lisboa, Fundação Francisco Manuel dos Santos, pp. 227-402.

Costa, Filipe Santos (2020), Lares e Covid: um filme de terror global, Jornal Eco, 6 Setembro 2020.

Decreto-Lei n. ${ }^{\circ} 163 / 2006$ de 8 de Agosto do Ministério do Trabalho e da Solidariedade Social, Diário da República n. ${ }^{\circ}$ 152/2006, Série I de 2006-08-08.

Departamento de Prestações e Contribuições (2020), Guia Prático. Estatuto do Cuidador Informal: Cuidador Informal Principal e Cuidador Informal não Principal (8004 - v1.02), Instituto da Segurança Social, I.P..

Direção-Geral da Saúde (2020), Ponto de Situação Atual em Portugal.

Fonseca, António M. (org.) (2018), Boas Práticas de Ageing in Place. Divulgar para valorizar. Guia de boas práticas, Fundação Calouste Gulbenkian / Faculdade de Educação e Psicologia - Universidade Católica Portuguesa. 
Instituto Nacional de Estatística (2020a), População residente $\left(\mathrm{N}^{\circ}{ }^{\circ}\right)$ por Local de residência (NUTS - 2013), Sexo e Grupo etário; Anual - INE, Estimativas anuais da população residente.

Instituto Nacional de Estatística (2020b), Censos 2011, Pessoas residentes segundo o grupo etário, por estatuto da pessoa na família.

Instituto Nacional de Estatística (2020c), Proporção de indivíduos com idade entre 16 e 74 anos que utilizaram Internet nos 12 meses anteriores à entrevista (\%) por Grupo etário; Anual - INE, Inquérito à utilização de TIC pelas famílias.

Jornal Médico (2020), Três em cada dez portugueses que se sentiram doentes durante a pandemia não recorreram aos cuidados de saúde.

Moreira, Amílcar; Alda Botelho Azevedo; Luís P. Manso; e Rui Nicola (2019), Financial and Social Sustainability of the Portuguese Pension System, Lisboa, Fundação Francisco Manuel dos Santos.

Serviço Nacional de Saúde (2020), Estruturas Residenciais para idosos.

World Health Organization (2015), World report on ageing and health, Genebra, World Health Organization.

World Health Organization (2020a), WHO Coronavirus Disease (COVID-19) Dashboard.

World Health Organization (2020b), Preventing and managing COVID-19 across long-term care services: policy brief, Genebra, World Health Organization. 
Entrevista realizada a Alda Botelho Azevedo no âmbito da rubrica "Um olhar sociológico sobre a crise Covid-19", publicada a 26 de maio de 2020.

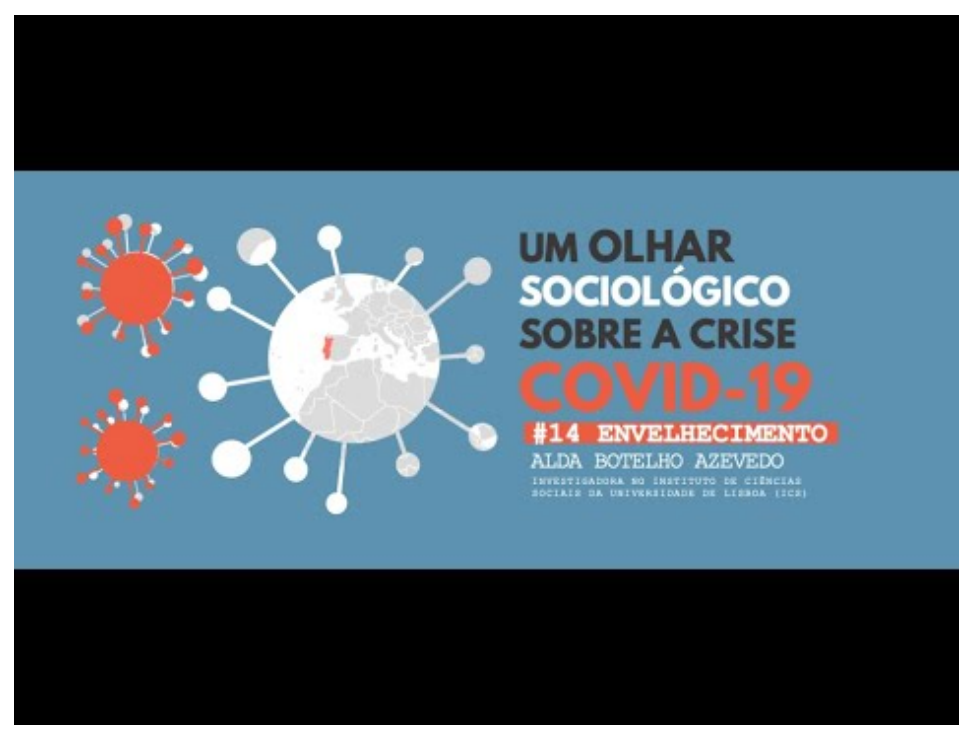




\section{CAPÍTULO 12}

\section{A DESIGUALDADE ECONÓMICA E A CRISE EXISTENCIAL DO PAÍS}

\section{Frederico Cantante}

Investigador Doutorado do COLABOR

\section{PIB e (des)emprego}

Os debates sobre desenvolvimento económico e desigualdade são antigos e plurais. Desde logo, a análise da relação entre o patamar de desenvolvimento dos países e os seus níveis de desigualdade, a medição e compreensão dos impactos da desigualdade no crescimento económico, a problematização dos efeitos negativos da elevada desigualdade (que tendem a diminuir o bem-estar social potencialmente associado a um determinado rendimento agregado dos países) ou a análise dos principais beneficiários do crescimento económico e dos principais perdedores num contexto de recessão económica. ${ }^{1}$

Em relação a esta última questão, sabemos que quem mais beneficiou do crescimento económico das últimas décadas foram os grupos do topo da distribuição do rendimento. Entre 1980 e 2016, 18\% do crescimento económico na Europa foi "capturado" pelos 1\% com rendimentos mais elevados - valor que atinge os 35\% nos EUA/Canadá (Alvaredo et al., 2018). Sabemos também que os que mais perderam na anterior crise económica e financeira foram os grupos da base da distribuição. Tal como foi demonstrado por Rodrigues, Figueiras e Junqueira (2016) a respeito do caso português, o rendimento disponível dos 10\% mais pobres diminuiu 25\% entre 2009 e 2014, um valor cerca de duas vezes superior face ao registado em termos médios para o

\footnotetext{
1 Este texto teve uma primeira versão, mais sintética, intitulada "O que significa mesmo uma queda de $10 \%$ do PIB?", publicada no blog da FFMS.
} 
conjunto da população. Os proventos do crescimento não são distribuídos democraticamente. A fatura das recessões também não.

○ principal indutor de aprofundamento da desigualdade de rendimento em Portugal na anterior crise foi o aumento muito acentuado do desemprego, em particular do desemprego desprotegido. Este mecanismo de aumento da desigualdade está novamente a produzir efeitos no atual contexto e a sua magnitude não é, até agora, superior graças às sucessivas medidas extraordinárias aprovadas pelo governo vocacionadas para a manutenção do nível de emprego e para o alargamento da proteção social, mas também aos apoios financeiros, contributivos e fiscais às empresas. Os trabalhadores por conta de outrem precários, os trabalhadores independentes economicamente dependentes, os microempresários, os mais desqualificados, os trabalhadores das atividades fortemente dependentes do turismo e os das artes e espetáculos têm sido os mais afetados e os que enfrentarão no curto e médio prazo situações de maior carência económica (extrema, em muitos casos). Apesar das medidas emergenciais, a queda de muitos deles não foi amortecida pela rede de proteção social ou foi-o de forma insuficiente - e com condicionalismos excessivos, em alguns casos. Num contexto recessivo terão grandes dificuldades em encontrar trabalho.

$\bigcirc$ aumento abrupto dos números do desemprego registado e a abrangência do regime simplificado de layoff são tremendos. Tal como é tremenda a pergunta "quantos empregos serão destruídos por uma queda abrupta do PIB?". De acordo com as estimativas do Banco de Portugal, a queda do PIB em Portugal, no ano de 2020, será de 8,1\% (projeção de 6/10/2020) - um valor mais baixo em relação à projeção anteriormente apresentada, segundo a qual o PIB iria contrair 9,5\% (ou ainda mais, nos cenários mais pessimistas veiculados nesse momento). A correlação entre o aumento do PIB e a criação de emprego pode não ser simétrica à verificada entre a queda do PIB e a destruição de emprego, desde logo devido ao papel que as políticas públicas podem exercer, mas também à capacidade de resistência de uma parte das empresas (as de maior dimensão, nomeadamente), 
durante algum tempo, a períodos recessivos. Mas façamos um exercício simples (simplista, concedo): entre 2013 e 2019, o PIB cresceu em termos reais cerca de 13,6\% (contas a partir de dados da AMECO) e, nesse período, houve uma criação líquida de emprego de 484 mil indivíduos; assumindo um efeito simétrico (cuja admissibilidade faz sentido tendo em conta que a destruição de emprego e a incidência do layoff estão a ser mais intensas nos sectores que suportaram boa parte da criação de emprego entre 2013 e 2019), a queda do PIB de $8,1 \%$ implicaria uma destruição de cerca de 290 mil postos de trabalho cerca de 340 mil novos desempregados num cenário de queda do PIB de $9,5 \%$. Como se referiu atrás, as medidas diretas e indiretas de apoio ao emprego mitigaram o impacto da queda acentuada da atividade económica. Mas essa capacidade é necessariamente limitada. E o que trará o ano de 2021? Muito provavelmente mais recessão ou um crescimento pouco significativo. É neste momento muito pouco provável a admissibilidade de uma recuperação de amplitude significativa.

As respostas são difíceis num contexto de incerteza extrema como é o atual. Mas sabemos algumas coisas: muito dificilmente a criação de emprego no curto e médio prazo poderá ser sustentada nas atividades económicas fortemente dependentes do turismo; e mesmo que tal fosse possível, não seria desejável que acontecesse dada a vulnerabilidade estrutural que esse perfil de especialização implica; é necessário reorientar o perfil de especialização da economia portuguesa e qualificar os atuais e futuros trabalhadores e empregadores; é fundamental alargar de forma sustentada os mecanismos de proteção social e combater de forma firme as várias formas de precariedade de quem trabalha. Face às incertezas do presente, é necessário assumir que os apoios excecionais às empresas, ao emprego e aos desprotegidos poderão ter uma duração relativamente longa (mais longa do que o ano de 2020), mas é também imprescindível preparar um futuro económico e social mais robusto e equitativo. 
Um país no divã: a crise existencial que sobreveio à crise económica

O ano de 2019 é um mundo distante. Esta impressão será certamente partilhada em várias latitudes do globo, devido às ruturas que a atual pandemia introduziu nos estilos de vida e nos projetos pessoais e profissionais de cada um, bem como na deterioração, muitas vezes dramática, das condições materiais de existência de milhões de pessoas. A distância subjetiva e material face a um tempo de normalidade é particularmente evidente em Portugal. Nessa normalidade, o país apresentava resultados orçamentais positivos sem paralelo em democracia e apoiava-se num mercado de trabalho que tinha gerado quase 500 mil empregos desde 2013 - com tudo o que isso implica no aumento global do rendimento disponível das famílias e na redução de despesa da proteção social. Portugal tinha voltado a ser um bom aluno na Europa - aluno travesso quando ousou aumentar significativamente o salário mínimo nacional -, e a devastação social que emergiu da anterior crise (e das políticas que a potenciaram) parecia também ela parcialmente ultrapassada. $\bigcirc$ país tendeu a melhorar e a vida das pessoas também. O problema é que as vulnerabilidades estruturais subsistiram. Agudizaram-se, até, em certas áreas.

O modelo de desenvolvimento económico dos últimos anos apresenta vários problemas, entre os quais o facto de se basear em áreas de especialização de baixo valor acrescentado, em atividades económicas que tendem a alimentar-se de precariedade laboral e numa estrutura empresarial fortemente atomizada.

A especialização em atividades de reduzido valor acrescentado tende a refletir-se em salários baixos. Se o aumento nominal de 95 euros entre 2015 e 2019 (130 euros entre 2015 e 2020) permitiu melhorar sensivelmente a situação dos trabalhadores mais mal remunerados, a verdade é que metade dos trabalhadores do setor privado continuavam a auferir, em 2018, cerca de menos de 800 euros mensais. $O$ salário mínimo está cada vez mais próximo do salário mediano e, em termos 
reais, os salários médios aumentaram de forma pouco significativa em quase todo o período mencionado.

Em relação à precariedade contratual, Portugal é um dos países europeus onde este fenómeno está mais disseminado e em que a involuntariedade da contratação não-permanente é mais expressiva: cerca de oito em cada dez trabalhadores (81,5\%) com vínculos não permanentes referem que estão nessa situação porque não conseguiram encontrar um trabalho com vínculo permanente, valor significativamente acima do apurado para os países da UE27 (51,5\%). Estes valores dizem respeito ao total da população empregada. Atentando apenas no setor privado (e nos trabalhadores do setor público com contratos individuais de trabalho), a incidência da precariedade contratual é ainda mais vincada: 36,4\% tinham, em 2018, contratos não permanentes, um valor que tem vindo a aumentar de forma sustentada nos últimos anos, e que se explica em grande medida pelo peso desproporcionado da criação de emprego em setores onde esse tipo de vínculo tende a ter uma expressão maior, nomeadamente o conjunto de atividades que orbitam em torno do turismo. Veja-se que, entre 2013 e 2018, 76\% do emprego líquido criado no setor privado baseou-se em contratações precárias (mais 377 mil trabalhadores por conta de outrem com contratos não permanentes, num total de 494 mil postos de trabalho criados em termos líquidos).

Os trabalhadores por conta própria, isolados ou empregadores, enfrentam também situações precárias na relação com o emprego. Essa realidade é evidente no caso dos falsos trabalhadores independentes, mas atinge igualmente uma parte significativa dos trabalhadores por conta própria sem empregados ou os que empregam um número muito reduzido de trabalhadores (microempresários). Na verdade, a estrutura empresarial portuguesa é fortemente atomizada. Veja-se que $96 \%$ do tecido empresarial é constituído por microempresas, grande parte delas com apenas uma pessoa ao serviço (o seu proprietário), que tendem a ter um perfil financeiro particularmente suscetível (Caldas, Silva e Cantante, 2020). 
As precariedades de inserção no mercado de trabalho e um modelo de proteção social cada vez mais seletivo (com algumas exceções) traduzem-se na desproteção de uma fatia muito significativo dos trabalhadores. Normalizou-se o facto de metade dos desempregados não ter acesso ao subsídio de desemprego, algo impensável no início do milénio e que ajuda a explicar porque é que 47,5\% da população desempregada encontrava-se, em 2018, numa situação de risco de pobreza (32,2\% em 2003). A precariedade do trabalho por conta de outrem é um fator que exponencia os riscos de desemprego (em períodos de normalidade e ainda mais em contextos de crise) e restringe as possibilidades de acesso à proteção social. E, no caso dos trabalhadores por conta própria, os mecanismos de proteção no desemprego introduzidos durante o período de intervenção da troika em Portugal mostraram-se muito pouco efetivos.

O crescimento económico e do emprego verificado nos últimos anos permitiu sarar parte das feridas causadas pela Grande Recessão. Algumas das políticas de rendimento melhoraram efetivamente as condições de existência da população com menores recursos. Alguns dos dogmas do anterior ciclo político defendidos cá dentro e lá fora, em particular a inevitabilidade e desejabilidade da desvalorização interna, com tudo o que isso acarreta do ponto de vista da (des)regulamentação das relações laborais e da (des)proteção social, foram desconstruídos - pelo menos em parte. Mas vários dos desequilíbrios no mundo do trabalho persistiram e o crescimento económico do país alavancou-se, em boa medida (embora não exclusivamente), em atividades económicas e em emprego estruturalmente vulneráveis. A especificidade da atual crise, em particular os seus impactos diretos nos setores ligados ao turismo, colocou em evidência a fragilidade do tipo de crescimento económico e do emprego verificado nos últimos anos. Os impactos da atual crise são transversais à atividade económica e à estrutura do emprego, mas penalizam de forma mais severa certos setores (os que mais contribuíram para os sucessos pré-Covid-19) e categorias de trabalhadores (os mais precários, menos qualificados e/ou empregados 
nas atividades do alojamento e restauração, artística, dos espetáculos e recreativas e também das atividades administrativas e dos serviços de apoio) (Silva et al., 2020).

Percebemos agora que as principais forças motrizes que alavancaram o crescimento dos últimos anos são estruturalmente frágeis. Nas ruínas provocadas até agora pela Covid-19 e na destruição económica e social que se antevê ser difícil de contrariar no curto e médio prazo, deparámo-nos com a necessidade de encontrar um modelo de desenvolvimento mais industrializado, menos dependente do exterior, com introdução de mais inovação e tecnologia na produção. Elaborámos a uma mão um documento estratégico que servisse de guião ao robustecimento da economia e da sociedade portuguesa. Admitimos que precisamos de ir por outro caminho, embora ainda não seja totalmente claro que caminho é esse.

$\mathrm{Na}$ prospeção desses caminhos afirma-se que as crises económicas são oportunidades. Não é verdade. As crises são, digamos assim, crises. Ou seja, períodos em que de forma mais ou menos grave, devido a problemas estruturais mais ou menos latentes, em contextos onde as políticas públicas têm uma capacidade muitas vezes limitada de conter parte significativa dos problemas emergentes, os países ou regiões são impactados negativamente numa ou em mais esferas da vida coletiva. Há, na verdade, muito menos oportunidades nas crises. A maior parte das pessoas encontrará essencialmente muros, abismos. Talvez seja preferível afirmar que contextos como o atual responsabilizam as políticas públicas no sentido de serem criadas condições de robustecimento do tecido económico e social dos países e regiões. Se parecem existir consensos em relação à necessidade de superar um modelo de desenvolvimento intrinsecamente vulnerável, as políticas concretas merecem maior debate, maior especificação. Importa também alargar o debate das apostas estratégicas no campo económico à proteção social e a outros instrumentos de política pública, em particular na área da fiscalidade e ao nível da regulação das relações laborais. É por aqui que se poderão criar condições que favoreçam um crescimento económico sustentado e nivelador do ponto 
de vista da distribuição dos recursos. Entre um futuro que se quer diferente, mais robusto, mais produtivo, mais igualitário, e um passado recente feito de sucessos de amplitude limitada e pouco estruturantes, Portugal olha-se ao espelho e problematiza-se. A crise sanitária, económica e social que o país atravessa reflete-se hoje com bastante evidência numa crise existencial que importa superar.

\section{Efeitos da Covid-19 nas desigualdades de rendimento}

A atual crise económica terá efeitos particulares na distribuição dos recursos monetários consoante o tipo de rendimento em causa. Em relação ao rendimento disponível, o nível de desigualdade na sua distribuição tenderá a definir-se pela oposição entre população empregada e desempregada. A extensão dessa desigualdade dependerá da efetividade das políticas destinadas à manutenção dos postos de trabalho e de outros instrumentos de apoio às empresas no sentido de se conter a vaga de desemprego, mas também da cobertura da proteção social aos trabalhadores que transitarem do emprego para a situação de desemprego. Parece ser neste momento evidente que a manutenção do nível de emprego e a sobrevivência das empresas dependerá de apoios públicos muito significativos. Não é por acaso que o governo já admitiu que o mecanismo de retoma à atividade económica, menos generoso para as empresas em relação ao regime de layoff simplificado inicialmente introduzido, será substituído por uma medida semelhante a este regime. Importará a este nível introduzir alguma condicionalidade no acesso ao apoio que permita garantir que os recursos disponíveis são encaminhados para as empresas que de facto necessitam e que seja acautelado o respeito por um conjunto de regras associadas à limitação de distribuição de dividendos, à relação das empresas com paraísos fiscais, a proibições de despedimentos durante um período razoável, entre outras.

Embora este tipo de medidas tenha até agora permitido mitigar o aumento do desemprego, o avanço desta realidade é já bastante evidente e tenderá a aprofundar-se. A criação de medidas ad hoc e a 
facilitação no acesso às prestações existentes permite alargar a cobertura da proteção social e, portanto, amortecer parcialmente a queda dos rendimentos - diminuindo por essa via a amplitude do aumento da desigualdade. Mas muitas famílias enfrentarão situações de pobreza e destituição material. Na verdade, o país está já a enfrentar uma situação de emergência social grave. O número de famílias que recorrem à caridade para não passar fome é cada vez mais elevado e isso não é tolerável se entendermos a proteção social como um direito social inalienável.

No caso da população empregada, em particular entre os assalariados, a crise económica poderá ser acompanhada, no curto prazo, por um nivelamento das retribuições, já que a transição do emprego para o desemprego incidirá sobretudo nos trabalhadores precários e/ou de atividades pior remuneradas. O salário médio da base da distribuição deverá, portanto, aumentar, favorecendo a redução da desigualdade face à parte superior da distribuição. No entanto, no médio prazo, o exército de reserva de desempregados já em formação tenderá a pressionar os salários e a nivelar por baixo as (re)entradas no emprego, potenciando, portanto, o aumento da disparidade salarial. Também por isso é imprescindível conter, tanto quanto possível, o caudal de trabalhadores a transitarem para o desemprego, tal como reforçar a negociação coletiva.

Os efeitos atrás descritos da crise económica nos rendimentos poderão ser acompanhados por alterações profundas na provisão de serviços públicos, um canal redistributivo fundamental e pilar essencial de integração e coesão social. Caso a resposta para as dificuldades financeiras que se avizinham passe por cortar despesa na saúde e na educação, então não aprendemos nada com a crise anterior. Nem estamos a aprender com esta. 
Referências bibliográficas

Alvaredo, Facundo; Lucas Chancel; Thomas Piketty; Emmanuel Saez; e Gabriel Zucman (2018), World Inequality Report, Paris, World Inequality Lab.

Caldas, José Castro; Ana Alves da Silva; e Frederico Cantante (2020), As Consequências Socioeconómicas da COVID-19 e a Sua Desigual Distribuição, Lisboa, CoLABOR.

Rodrigues, Carlos Farinha (coord.); Rita Figueiras; e Vítor Junqueira (2016), Desigualdade do Rendimento e Pobreza em Portugal. As Consequências Sociais do Programa de Ajustamento, Lisboa, FFMS.

Silva, Pedro Adão; Renato Miguel do Carmo; Frederico Cantante; Catarina Cruz; Pedro Estêvão; Luís Manso; Tiago Santos Pereira; e Filipe Lamelas (2020), Trabalho e Desigualdades no Grande Confinamento II: Desemprego, Layoffe Adaptação ao Teletrabalho, Lisboa, CoLABOR. 
Entrevista realizada a Frederico Cantante no âmbito da rubrica "Um olhar sociológico sobre a crise Covid-19", publicada a 7 de maio de 2020.

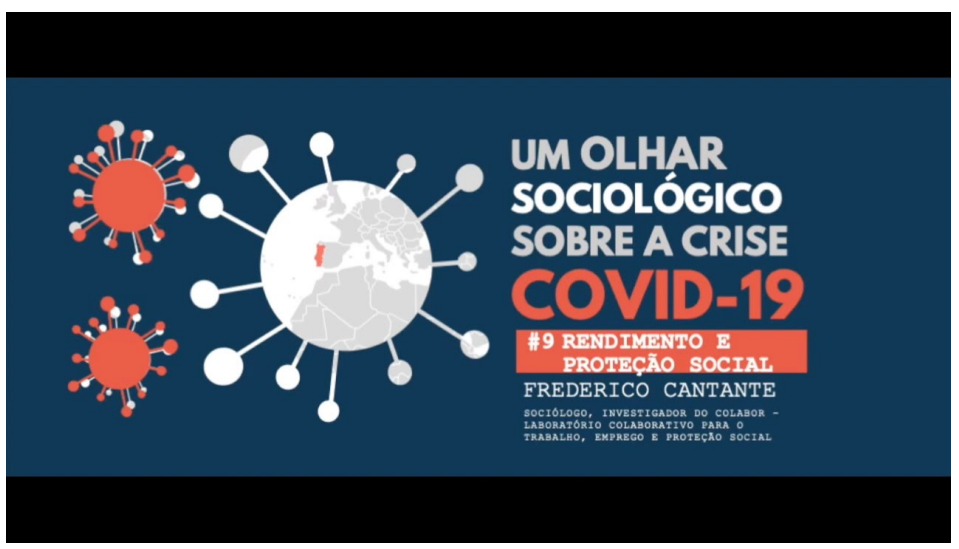




\section{CAPÍTULO 13}

\section{A POBREZA E A PANDEMIA EM PORTUGAL, UM ENSAIO}

\section{Fernando Diogo}

Professor Associado com Agregação, Universidade dos Açores e CICS.NOVA

Ao fazermos este ensaio sobre a relação entre a pobreza em Portugal e a pandemia, a primeira questão que emerge respeita à incerteza. Incerteza pelos escassos dados sobre o que aconteceu desde que os efeitos sociais e económicos da pandemia se fizeram sentir em Portugal e no mundo e incerteza em relação ao que vai acontecer nos próximos meses. ${ }^{1}$

Podemos encontrar quatro grandes questões de enquadramento que fundamentam esta incerteza. Assim, em primeiro lugar, tudo o que pudermos dizer agora é provisório e terá sempre alguma distância da realidade, considerando que esta se encontra numa fase de mudança intensa e rápida. O que está aqui em causa é, portanto, o efeito do tempo, amplificado pela intensidade da mudança.

Acresce que o fenómeno tem tão pouco tempo - no momento em que escrevemos - que ainda não se produziram as estatísticas necessárias para se fazer uma primeira verificação dos efeitos sociais já acumulados. Excetuam-se aqui algumas estatísticas económicas e de emprego que, por terem uma periodicidade mensal ou trimestral, permitem já algumas comparações e análises (INE, 2020). O mesmo é verdade para a miríade de estudos que foram feitos e que estão a ser feitos. Mas, mesmo estes estudos, ainda precisam de ser lidos e

\footnotetext{
1 Este ensaio é financiado por fundos nacionais através da FCT - Fundação para a Ciência e a Tecnologia, I.P., no âmbito do projeto «UIDB/04647/2020» do CICS.NOVA - Centro Interdisciplinar de Ciências Sociais da Universidade Nova de Lisboa.
} 
assimilados, nuns casos, e de apresentarem resultados, noutros. ${ }^{2}$ Além disso, são prejudicados pelo facto dos fenómenos sociais que analisam estarem a mudar com rapidez. Os seus resultados podem-se desatualizarem depressa. ${ }^{3}$

Em terceiro lugar, muito do que vai acontecer nos próximos tempos dependerá da rapidez da recuperação. Se esta for bastante rápida muitos dos problemas nacionais ficarão atenuados (mas não resolvidos). A profundidade da crise económica nacional, e nos nossos principais parceiros comerciais, indicia que esta recuperação não será rápida mas tudo está - ainda - por perceber e até por acontecer.

Em quarto, não nos podemos esquecer de que existe um contexto internacional que influencia decisivamente o que se passa no país, acentuando a incerteza. Desde logo na União Europeia (UE), mas também nos EUA e no Sul Global.

No que respeita à UE está em causa a incerteza resultante das negociações e dos equilíbrios políticos de grande complexidade para apoio à recuperação. É certo que há já algum fumo branco - os apoios entretanto decididos. Mas há uma margem de incerteza associada ao evoluir da situação e às negociações futuras que espoletará. $O$ êxito das negociações passadas não é garantia do êxito das negociações futuras. Para mais, o Brexit parece um poço sem fundo de complicações, amplificando a incerteza.

No segundo caso está em causa o poder que os EUA têm a nível global. O poder norte-americano no mundo está longe de se confinar às suas dimensões económica e militar, assumindo uma centralidade enorme do ponto de vista das indústrias culturais e da produção científica, sem esquecer as organizações internacionais e a influência bi e multilateral (dimensão política). Aqui, a incerteza está associada aos

\footnotetext{
2 É nesse sentido que a Universidade de Oxford criou uma aplicação para dar conta de todo o trabalho científico que tem sido feito no mundo. Ver aqui.

3 Especificamente sobre a pobreza veja-se Veiga, Cruz e Santos (2020). De notar que os resultados deste trabalho são, em nossa opinião, claramente enviesados pela natureza dos inquiridos, reduzindo a sua pertinência.
} 
efeitos disruptivos das principais bandeiras políticas do partido republicano e do seu presidente. Ou seja, o poder dos EUA amplifica a todo o mundo a incerteza trazida ao sistema político norte-americano por um partido republicano cuja força motriz é uma ideologia que maximiza as desigualdades sociais e menospreza a ciência.

No terceiro caso, releva-se a influência do Sul Global na produção da incerteza. Aqui estão em causa os potenciais efeitos na situação política, económica e epidemiológica nos grandes volumes populacionais que este encerra. Há que contar com a corrupção (endémica, generalizada e de grande amplitude), bem como a desorganização e falta de recursos a todos os níveis. ${ }^{4}$ Tudo fatores que amplificam a incerteza (e o impacto global da pandemia) no papel que o Sul Global joga no desenrolar dos acontecimentos, no mundo como em Portugal.

Mas, mau grado toda a incerteza, a rapidez e a profundidade da mudança que referimos, é já inegável que os cidadãos mais afetados pelas consequências do que está a acontecer, e do que acontecerá, são os mais vulneráveis e os pobres. Em Portugal como no mundo em geral.

${ }^{4}$ Sobre os fatores que condicionam o desenvolvimento a Sul veja-se, por exemplo, Easterly (2002), Acemoglu e Robinson (2013) e Sachs (2017). Em concreto, Sachs desenvolve argumentos minimizando o impacto da corrupção no desenvolvimento, ao contrário do que defendemos. 
Não é precisamente uma novidade. Na anterior crise políticoeconómica ${ }^{5}$ (grosso modo 2008-2014) já tinham sido os mais pobres a serem mais afetados, como ficou cabalmente demonstrado (Rodrigues, Figueiras e Junqueiro, 2016 e Wall et al., 2015). Isso está associado a diversos fatores que os tornam especialmente desprotegidos. Referimonos, em especial, i) à escassez de todo o tipo de recursos que os caracteriza, destacando-se nesta instância a influência política (cf. Champagne, 1993); ii) e à posição periférica no sistema produtivo que, em regra, ocupam. Aqui agigantam-se as questões da informalidade, ${ }^{6}$ da precariedade e da escassez dos rendimentos de trabalho.

Consideramos que a atual crise, no contexto português, está a ter efeitos em especial em três áreas: i) no trabalho: nos baixos salários, na precariedade e informalidade, no desemprego; ii) na educação, entre os que têm menores qualificações escolares e os que têm piores

\footnotetext{
5 Temos vindo a defender que a crise anterior foi, no seu essencial, política. Claro que com consequências económicas claras e graves. Estas consequências tenderam a ocultar a origem política da crise. Assim, consideramos que em Portugal existem fatores específicos no sistema político que motivaram a crise e que justificam a sua gravidade e amplitude (e que são anteriores a 2008, embora a crise internacional os tenha amplificado). Estes fatores estão associados à apropriação do Estado pelas elites, para angariarem recursos em seu benefício e em detrimento do desenvolvimento socioeconómico da sociedade portuguesa. Em nosso entender, este processo de instrumentalização está institucionalizado e não se tem verificado qualquer alteração significativa. Não interessa qual o partido que está no poder. É algo que transcende pessoas, estilos de liderança e programas (cf. Acemoglu e Robinson, 2013 para um enquadramento teórico desta afirmação). Com este pano de fundo é de esperar que os recursos do Estado português, próprios e vindos da União Europeia, continuem a ser canalizados, em larga medida, para as elites, tendo como consequência a continuação da estagnação da economia e o arrastar do atraso no desenvolvimento.
}

6 Entende-se aqui informalidade como o desenvolvimento de atividades que não se enquadram nos direitos e obrigações legais associadas ao trabalho. Nestes casos não são pagas contribuições e impostos e os trabalhadores não gozam de proteção no desemprego e na doença, bem como não se constitui direito à reforma. Em regra, a informalidade está associada a situações em que, com regularidade, as atividades são desempenhadas em contextos laborais penosos e perigosos, sem respeito pelas regras de segurança legalmente instituídas. No limite, e apenas em alguns casos, podem ser atividades ilegais. 
desempenhos escolares (os primeiros são os ativos e os segundos os atuais alunos); iii) na saúde: considerando os que mais precisam de um sistema de saúde e que não podem recorrer a uma alternativa privada. Neste caso estão especialmente em causa os idosos, os pobres e os indivíduos com problemas crónicos incapacitantes.

Se é possível abordar o problema através da análise das áreas mais atingidas, o nosso foco passa, sobretudo, por uma análise centrada nos públicos mais afetados (onde estas áreas estão consideradas). Aqui há vários recortes a ter em consideração para compreendermos o que se está a passar.

Desde logo um primeiro: é necessário distinguir entre os que já eram pobres antes da crise e os que ficaram ou ficarão numa situação de pobreza por causa da crise. É possível que as problemáticas de uns sejam diferentes das problemáticas dos outros e, por isso, precisem de soluções algo distintas.

Em concreto está em causa a definição de vulnerabilidade e o que ela significa para a análise do fenómeno da pobreza. Aqui, a grande problemática é a falta de empregos de qualidade ${ }^{7}$ no seio do agregado familiar, por contraponto com outros casos em que as problemáticas dos indivíduos e das suas famílias não se esgotam na escassez e na qualidade dos empregos e dos recursos monetários que deles derivam. Sendo certo que entre os que já eram pobres muitos terão apenas como problemática a escassez de recursos (monetários e de outros tipos, como os escolares). Cremos que é entre os vulneráveis empobrecidos que existe um maior número de indivíduos onde a questão dos recursos é a mais relevante ou a única relevante. Portanto, com mais probabilidade, uma família vulnerável caída em situação de pobreza precisará apenas (e é um apenas muito grande) de melhorar a situação laboral dos seus membros para deixar a situação de pobreza.

Há aqui que fazer uma observação importante de carácter metodológico para se compreender bem o impacto da pobreza e do

\footnotetext{
7 Temos vindo a definir empregos de qualidade a partir de quatro indicadores: ordenado, precariedade, penosidade e perigosidade das atividades desenvolvidas.
} 
desemprego nos vulneráveis empobrecidos. Esta observação, dada a sua complexidade, tem que ser dividida em dois pontos. Num primeiro chama-se a atenção para que a base de cálculo da taxa de pobreza é o Agregado Doméstico Privado (em resumo o agregado familiar). Isto é, o INE recolhe os rendimentos do agregado e depois individualiza-os de acordo com uma fórmula - neste caso a escala modificada da OCDE8, validada pelo Eurostat. Isto significa que um indivíduo pode ter um rendimento que o coloca acima do limiar da pobreza mas como este rendimento é somado ao conjunto de rendimentos da sua família e depois individualizado, o resultado pode ser, e é em muitas situações, a de que é pobre (mesmo com o ordenado que o coloca acima do limiar da pobreza). Mas a situação gerada também pode ser de vulnerabilidade, se esse rendimento individualizado for pouco acima do limiar de pobreza.

O segundo ponto a ter em conta respeita às características específicas dos vulneráveis. Estes têm duas características importantes: por um lado os rendimentos da sua família colocam-nos pouco acima do limiar de pobreza (como afirmado); por outro, são vulneráveis (justamente) a um qualquer acidente de percurso. Desde que este se traduza numa perda de rendimento, seu ou de outro membro do agregado: uma situação de desemprego, uma doença grave, um acidente grave, uma morte. 9 Em Portugal a pobreza é persistente e existem indivíduos que entram e saem dessa situação várias vezes ao longo da vida (Costa et al., 2008; Alves, 2015; Bastos, 2015). Em particular em situações de crise económica, como a que vivemos neste

\footnotetext{
8 Assim: os rendimentos são distribuídos com um peso (ponderação) de 1 para o primeiro adulto, de 0,5 para os restantes indivíduos com 14 ou mais anos e de 0,3 para os que têm menos de 14 anos.

9 Temos vindo a defender a existência do que designamos por três D's da pobreza. Por contraponto aos três D's existentes no programa do MFA, por alturas do 25 de Abril: Desemprego, Doença e Divórcio. Estes sistematizam e resumem os fatores que levam à pobreza, que permitem a sua persistência no tempo ou que aumentam a sua intensidade.
} 
momento. Portanto, o principal problema dos vulneráveis empobrecidos é o desemprego no seio do agregado familiar.

Além destes dois pontos, é ainda preciso fazer um alerta importante, um terceiro ponto. A forma como a taxa oficial de pobreza é calculada (taxa de risco de pobreza no léxico do Eurostat e do INE) torna-a vulnerável às alterações da conjuntura. Concretizando, a base de cálculo do limiar da pobreza é a mediana do rendimento nacional, ora, nas situações de crise esta mediana desce - como está a acontecer neste momento - e o resultado é que num ano um determinado rendimento está abaixo do limiar da pobreza e, no ano seguinte, já está acima. Isto implica que em situações de crise económica grave, como a que vivemos, a taxa de pobreza não reflita toda a amplitude do agravamento da pobreza. Foi precisamente isso que aconteceu na crise de 2008-2014. O que está em causa é um efeito estatístico e não tem correspondência com os rendimentos efetivamente auferidos pelos indivíduos. 10 Este problema torna difusas as fronteiras entre a pobreza e a vulnerabilidade.

Precisamente, pelo facto dessas fronteiras serem difusas, existem diversas situações em que faz sentido falar, ao mesmo tempo, de pobres e de vulneráveis. Algo que temos vindo a ter em atenção.

Um outro recorte a ter em conta tem a ver com o que se passa dentro das pessoas que já estavam em situação de pobreza. Nem todas estão a ser atingidas da mesma maneira. De seguida apresentaremos as nossas reflexões sobre algumas categorias sociais de indivíduos nessa situação. Estas categorias são, em primeiro lugar, organizadas em função da sua relação com o mundo do trabalho. Isto tendo em consideração que vivemos numa sociedade de classes onde a posição do mundo do trabalho é determinante para prover os indivíduos de recursos (que lhes permitam não serem pobres) e o seu lugar de classe.

10 Cientes deste problema, o INE produziu taxas de risco de pobreza ancoradas a 2009, isto é, tendo como base de cálculo o ano de 2009 e os valores de outros anos (2009, 2010 e 2011). Isso permitiu uma comparação mais aturada do evoluir da situação. Escusado será dizer que a taxa de pobreza assim calculada foi muito maior do que a taxa oficial (INE, 2014). 
Além disso, o posicionamento no mundo do trabalho também condiciona a produção e reprodução das suas identidades sociais. E, em segundo, são organizadas em função do volume demográfico que comportam. São muitos os indivíduos que nelas podem ser agregados.

A primeira dessas categorias é constituída pelos que já deixaram o mundo do trabalho. Estamos a falar dos idosos reformados pobres (e pensionistas). Em nosso entender, este é o grupo menos atingido pelos efeitos sociais da epidemia na sua situação de pobreza. São, é já claro, bastante vulneráveis à epidemia em si mas as suas reformas, pelo menos enquanto não sofrerem cortes, devem dar-lhes alguma estabilidade financeira. Há, contudo, vários fatores preocupantes para este grupo, por um lado um possível aumento dos casos de solidão e, por outro, os impactos financeiros que a pandemia pode ter no seu rendimento. Em relação a este último caso, estão em causa dois cenários bastante prováveis. O primeiro respeita à necessidade de muitos terem de esticar a sua reforma para apoiar familiares - filhos e outros. O segundo tem a ver com o fenómeno inverso: diversos filhos, e outros familiares, complementam as pensões dos seus ascendentes com pequenas transferências de dinheiro. É muito possível que alguns deixem de estar em condições de poder continuar a proporcionar este apoio de família providência. Neste caso, a pensão não se reduz mas o dinheiro à disposição do(a) idoso(a) sofre uma diminuição, por uma ou por outra via. Em ambas as situações aumenta a intensidade ${ }^{11}$ da sua pobreza.

A estes fatores há que acrescentar, no caso dos idosos pobres, um outro, pressionando a sua qualidade de vida e, claramente, a sua própria morte: referimo-nos ao acesso aos serviços de saúde. Num contexto em que parte significativa dos recursos está consignada ao

11 A intensidade da pobreza refere-se ao facto de nem todos os pobres auferirem rendimento iguais. É muito diferente ter um rendimento a rondar o limiar da pobreza, metade disso ou mesmo menos. Todos estes casos referem-se a indivíduos pobres mas quanto mais longe do limiar de pobreza se posicionam, mais dura, mais intensa, é a sua pobreza. E para rendimentos muito baixos uma diferença de alguns euros tem um grande impacto nas despesas realizadas ao longo do mês e na qualidade de vida. 
problema da pandemia e onde, no sistema de saúde, existe um importante atraso de prestação de serviços, acumulado neste período pandémico, os idosos pobres não têm recursos para recorrem a uma alternativa privada.

Uma segunda categoria é a dos trabalhadores pobres, à qual podemos juntar a dos trabalhadores com baixos salários e rendimentos familiares próximos do limiar da pobreza (os vulneráveis). Se é certo que entre estas populações uma diferença de rendimento de 20, 30 ou 50 euros por mês é muito significativa, os dois grupos partilham uma grande vulnerabilidade no emprego. Quer pela informalidade dos vínculos laborais, quer pela precariedade, situações muito frequentes.

De notar que a informalidade e a precariedade não se distribuem de forma uniforme pelo tecido social, sendo muito mais prováveis entre os mais pobres (e os vulneráveis). Isto significa que a facilidade de os despedir é muito grande. Para alguns nem faz sentido falar em despedimento, dado que a forma como se relacionam com o mundo do trabalho não abriga esta figura. Por exemplo, um trabalhador a prazo que vê o seu contrato não ser renovado ou um empregado de um restaurante que faz umas horas ao fim de semana (sem descontos ou contrato) e que vê essa possibilidade esgotar-se, ou ainda um guia turístico por conta própria (com ou sem tuk-tuk) que se vê subitamente sem turistas.

A probabilidade de deixarem de ter atividade laboral é grande e a probabilidade de não estarem ao abrigo do subsídio de desemprego é ainda maior. Aqui, o que está em causa é o aumento da intensidade da pobreza para os que já são pobres e a entrada em situação de pobreza para os vulneráveis.

No entanto, existe um número indeterminado mas significativo de trabalhadores pobres que se encontram ao abrigo de um contrato sem termo. Neste caso, está em causa um salário, em regra baixo, associado a uma determinada composição do agregado familiar (Capucha, 2005; Diogo, 2007). Aqui, o que está em causa é uma família com um provedor único (de rendimentos) ou, nos casos em que há um segundo provedor, este aufere rendimentos (ainda mais) baixos e irregulares. Daí 
a situação familiar de pobreza. O desemprego deste provedor único, ou do segundo provedor, tem o efeito de aumentar a intensidade da pobreza.

Por outro lado, parte destes trabalhadores estão enquadrados em micro e pequenas empresas que, elas próprias, são vulneráveis à atual crise. Podemos encontrar aqui a possibilidade de termos empregados efetivos em situação de pobreza que se tornam desempregados por falência das suas empresas. Mais uma vez, a probabilidade de falência não se distribui de forma uniforme, é mais provável em empresas e sectores de atividade onde habitualmente se empregam os indivíduos em situação de pobreza: agricultura, pescas, turismo, serviços pessoais e domésticos, restauração e similares. Em regra empresas de pequena dimensão, com mão de obra intensiva e baixa produtividade. Estes fatores também têm impacto na probabilidade dos vulneráveis se tornarem pobres.

Para os trabalhadores que estão pouco acima do limiar da pobreza, uma perda parcial de rendimento, por layoff por exemplo, pode significar a entrada na situação de pobreza, e, mesmo que não signifique, as condições de vida vão certamente endurecer. Lembramos que quanto menor for o rendimento maior é o impacto de qualquer perda, mesmo que seja um terço. Nos salários mais baixos, de acordo com a lei de Engel (Clark, 2008), a maior parte do dinheiro é gasto nas necessidades mais básicas, em particular alimentação. Os cortes de um terço do rendimento são nessas necessidades, por contraponto com salários mais altos, onde há margem para se reduzir noutro tipo de despesas. Nestes últimos, mesmo que se corte nos bens alimentares, há margem para continuar a assegurar uma alimentação adequada, embora mais barata.

O layoff, nas suas várias formulações, também tem um efeito no Ganho. Isto é, no conjunto do rendimento do trabalho, onde se devem acrescentar outros ganhos para além do salário base e onde se destacam as horas extraordinárias. Em alguns casos, é o acumulado de horas extraordinárias mensais que aumenta o Ganho e impede a 
situação de pobreza (ou que a atenua). Em layoff não há trabalho nem, em consequência, acumulação destas horas extraordinárias.

Quer isto dizer que o layoff, associado à inexistência de outras componentes no Ganho, pode implicar o ingresso numa situação de pobreza ou o aumento da sua intensidade. Consoante se fale de agregados familiares vulneráveis ou pobres.

Uma terceira categoria a destacar é sempre muito desprotegida: os desempregados, aos quais podemos acrescentar os desocupados. Neste caso, o que está em causa é, por um lado, a competição acrescida pelas atividades laborais disponíveis, em especial os empregos. Para os indivíduos que já estão em situação de desemprego e desemprego de longa duração (ou desocupação), torna-se agora muito mais árduo encontrar um emprego. Por outro, a pressão do volume dos novos desempregados nos apoios sociais faz com que a competição por alguns destes apoios se torne maior. Desde logo, e por exemplo, estão em causa os programas ocupacionais. Estes últimos têm desempenhado um papel muito importante na atenuação dos efeitos mais graves da perda de rendimento e, ao mesmo tempo, permitem aos indivíduos ter uma relação com o mundo do trabalho que os dignifica, aos seus olhos e aos olhos dos outros que os rodeiam. ${ }^{12}$ Especialmente em situações de crise. Acresce que a pressão sobre os recursos públicos não se exerce apenas em função do maior número de desempregados. Existe uma concorrência forte para a sua alocação a outras necessidades sociais, designadamente para apoiar as empresas.

\footnotetext{
12 Isto não impede que os programas ocupacionais tenham algumas disfuncionalidades, quer para os seus beneficiários quer para a economia. Por exemplo, porque as instituições os preferem a empregos normais, prejudicando os putativos empregados e distorcendo o mercado de trabalho. Saem-lhes bem mais barato e não criam obrigações contratuais para a entidade contratante. Não obstante, em situações de crise aguda como a atual, são uma alternativa incontornável. Não é por acaso que as primeiras referências a este tipo de estratégia, neste tipo de condições, têm já mais de dois mil anos.
} 
Um segundo recorte nas populações pobres opõe as crianças e jovens até aos 17 anos $^{13}$ aos adultos. Este primeiro grupo não é pobre em si próprio, afinal crianças e jovens em idade escolar não são titulares de rendimentos. São pobres no seio de agregados familiares pobres. Contudo, os dados mostram que a pobreza das crianças e jovens é maior do que a pobreza em geral, e que os agregados familiares onde vivem têm uma probabilidade de pobreza acrescida em relação aos agregados onde não estão presentes (Bastos, 2015; Diogo, 2018). Acresce que, em regra, os apoios sociais do Estado dirigem-se aos idosos. Para os membros desta categoria social resta alguma coisa na escola, como as refeições e a Ação Social Escolar; o abono de família e o Rendimento Social de Inserção. Lembramos que o valor desta última prestação social está bastante abaixo do limiar da pobreza. Dependendo do agregado familiar, apresenta um montante máximo por indivíduo entre 20 e $30 \%$ desse limiar.

Se as famílias com crianças são já bastante afetadas pela pobreza, a crise deverá trazê-las para esta condição em maior número.

Mas os impactos da pandemia entre as crianças e jovens em situação de pobreza não se esgotam na dimensão financeira. Se, no caso desta categoria social, não se coloca a questão do trabalho, considerando que estão legalmente impedidos de trabalhar, colocamse diversas questões em relação à sua participação escolar. Desde logo, e em primeiro lugar, uma questão material, designadamente as suas maiores dificuldades de acesso às Tecnologias de Informação e Comunicação (TIC). Quer estejamos a falar de computadores e tablets, quer de acesso à internet. Esta foi uma questão muito discutida publicamente, resta ver com que consequências práticas.

Ainda do ponto de vista material, é incontornável mencionar as dificuldades que o confinamento e as aulas à distância trouxeram à sua alimentação, por via de uma menor possibilidade de acederem às

13 Seguimos aqui a definição das Nações Unidas, também adotada pelo Eurostat organismo produtor de estatísticas da União Europeia que orienta os conceitos usados pelo INE. 
cantinas e às refeições escolares. Esta é uma questão que pode passar despercebida mas que tem um grande peso para os indivíduos em situação de pobreza mais intensa. Lembremos que em muitos casos a fome está, literalmente, a uma refeição de distância.

Acresce o impacto no sucesso escolar durante o período de confinamento e as suas consequências duradouras na sua trajetória escolar. Lembremos que, em regra, em Portugal, o insucesso escolar está associado às classes mais baixas, onde a escolaridade dos pais é baixa (Benavente e Correia, 1980; Diogo e Diogo, 2013; Justino, 2013, por exemplo). Por um lado, a capacidade de trabalho autónomo que foi exigida no confinamento pode não ter estado ao alcance de boa parte destas crianças e jovens e, por outro, a baixa escolaridade dos seus pais impediu um apoio eficaz aos esforços escolares dos filhos. $E$ isto no contexto das dificuldades de acesso às TIC acima referenciadas. Para muitos, as suas desvantagens em relação aos demais amplificaram-se. Mas mesmo que o acesso às TIC tenha ficado resolvido, isso não tem um impacto mágico nas aprendizagens. Não basta ter os instrumentos, é preciso saber usá-los. A real dimensão do impacto do confinamento nas crianças e jovens mais pobres ainda está por medir mas isso não a torna menos real na vida dos indivíduos. ${ }^{14}$

Poderíamos multiplicar as populações especialmente vulneráveis à pobreza e aos efeitos da pandemia. ${ }^{15}$ Mas as categorias sociais já apresentadas cobrem a maior parte das situações e interseccionam-se com outras propostas de recorte da população pobre em categorias.

A probabilidade de se ser infetado não se distribui de forma uniforme no tecido social, tende a ser maior entre determinados grupos e categorias sociais. Em regra, os pobres são especialmente vulneráveis.

\footnotetext{
14 A última edição do Education at a Glance (OECD, 2020) apresenta já boas pistas para se discutir mais esta questão.

15 Como por exemplo: imigrantes, minorias étnicas, deficientes, reclusos e ex-reclusos, população sem-abrigo, toxicodependentes... todas estas categorias caracterizam-se por terem efetivos muito baixos e por estarem incluídas, de uma forma ou de outra, nas já referenciadas.
} 
Em primeiro lugar, porque não têm alternativa aos transportes públicos (para ir trabalhar, para ir para a escolar, ou ainda para qualquer outro fim). Em segundo, porque as atividades laborais que geralmente têm não podem ser desenvolvidas em teletrabalho. Os sectores de atividade onde se tendem a concentrar implicam o trabalho fora de casa e o contacto com os outros (na generalidade das situações), como é o caso dos serviços pessoais e domésticos ou da restauração, por exemplo. Assim, a probabilidade de contraírem o vírus e de o virem a passar aos seus familiares é grande. Para mais, muitas vezes vivem em espaços relativamente reduzidos, obrigando a uma proximidade física elevada. $\mathrm{E}$ o vírus vive, literalmente, da proximidade física.

Acresce que muitos destes indivíduos, mesmo doentes (ou assintomáticos positivos) poderão optar por ir trabalhar, expondo, em primeiro lugar, outros indivíduos em situação de pobreza à possibilidade de apanhar o vírus. Isto porque na economia informal, e mesmo em situação de precariedade, não há propriamente baixa por doença e as poupanças, em regra, não são muitas. Mesmo testando positivo terão que ir trabalhar, o não trabalho significa ausência de rendimento e esta ausência não é compensável por poupanças. Este é um problema já identificado, resta saber com que eficácia se têm implementado medidas mitigadoras.

Do ponto de vista territorial, os pobres tendem a concentrar-se em determinados lugares, sobretudo no que respeita à pobreza urbana (Capucha, 1990; Guerra, 1994; Carmo, Cachado e Ferreira, 2015). Portanto, a possibilidade de se apanhar um vírus num contexto urbano pobre, onde as pessoas estão mais expostas e onde têm obrigatoriamente de circular, é maior do que noutros contextos territoriais, mesmo que fisicamente próximos.

○ vírus não é democrático, contribui para a reprodução das desigualdades. Cremos que, no médio e no longo prazo, o principal efeito deste vírus, e da pandemia que provoca, é acentuar as desigualdades a partir das linhas de fratura sociais previamente existentes. Obviamente que as políticas implementadas, de todo o tipo e não apenas sociais em sentido estrito, terão um papel fundamental 
para minimizar o impacto do vírus, quer na economia quer na vida dos mais pobres.

As diferenças internacionais, estamos convictos, terão também como base as diferenças previamente existentes. Neste caso, e em primeiro lugar, entre países ricos e países em desenvolvimento. Mas também entre países do Norte e do Sul da Europa.

O Sul Global está obviamente menos preparado para enfrentar a crise, mas nunca saberemos com um mínimo de confiança o que lá vai acontecer. Está nas mãos das suas elites cleptocratas, mais preocupadas em prosseguir com a pilhagem sistemática dos seus recursos para benefício próprio do que com prioridades sociais ou económicas (cf. o conceito de instituições extrativas em Acemoglu e Robinson, 2013). Não cremos que este colonialismo interno tenha qualquer modificação. As pessoas simplesmente morrerão e nunca se saberá do que é que morrerão, isto perante a absoluta indiferença dessas elites, a incapacidade dos Estados e a indiferença cúmplice do Norte.

Em suma, o impacto desta crise nas desigualdades e na pobreza dependerá, como já se disse, das políticas aplicadas a nível nacional, europeu e nos países centrais. Neste momento cremos que está tudo em cima da mesa, todos os cenários são possíveis. Obviamente que a própria evolução da pandemia e da vacina tem um papel central.

Não obstante, existem distintas probabilidades de concretização destes cenários. Em nossa opinião é muito possível que assistamos a um reforço do neoliberalismo e, com ele, a um agravar das desigualdades e da pobreza, em todas as escalas territoriais. Os períodos de instabilidade e de incerteza tendem a reforçar as soluções autoritárias e, neste momento, as únicas ofertas dinâmicas de autoritarismo são as de direita. E nestas soluções de direta autoritária o neoliberalismo assume um papel central. 


\section{Referências bibliográficas}

Acemoglu, Daron e James A. Robinson (2013), Porque falham as nações: as origens do poder. da prosperidade e da pobreza, Lisboa, Temas e Debates.

Alves, Nuno Melo (2015), A dinâmica da pobreza em Portugal. Em Diogo, Fernando; Alexandra Castro; e Pedro Perista, Pobreza e exclusão social em Portugal: contextos, transformações e estudos, Ribeirão, Húmus, pp. 65-77.

Bastos, Amélia (2015), Pobreza infantil: diagnóstico e reflexão sobre os indicadores de aferição. em Diogo, Fernando; Alexandra Castro; e Pedro Perista, Pobreza e exclusão social em Portugal: contextos, transformações e estudos, Ribeirão, Húmus, pp. 101-113.

Benavente, Ana; e Adelaide Pinto Correia (1980), Obstáculos ao sucesso na escola primária, Lisboa, Instituto de Estudos para o Desenvolvimento.

Capucha, Luís (1990), Associativismo e modos de vida num bairro de habitação social, Sociologia, Problemas e Práticas (8), pp. 29-41.

Capucha, Luís (2005), Desafios da Pobreza, Oeiras, Celta.

Carmo, Renato Miguel do; Rita Cachado; e Daniela Ferreira (2015), Desigualdades em Tempos de Crise: Vulnerabilidades Habitacionais e Socioeconómicas na Área Metropolitana de Lisboa, Revista Portuguesa de Estudos Regionais (40), pp. 5-22.

Champagne, Patrick (1993), La vision médiatique. Em Bourdieu, Pierre (dir.), La misère du monde, Paris, Seuil, pp. 61-79.

Clark, Gregory (2008), Um adeus às esmolas: uma breve história económica do Mundo, Lisboa, Bizâncio.

Costa, Alfredo Bruto da (coord.); Isabel Baptista; Pedro Perista; e Paula Carrilho (2008), Um olhar sobre a pobreza: vulnerabilidade e exclusão social no Portugal contemporâneo, Lisboa, Gradiva.

Diogo, Ana; e Fernando Diogo (orgs.) (2013), Desigualdades no sistema educativo: percursos, transições e contextos, Lisboa, Mundos Sociais.

Diogo, Fernando (2007), Pobreza, Trabalho, Identidade, Oeiras, Celta. 
Diogo, Fernando (2018), A pobreza infantil e o Rendimento Social de Inserção em Portugal: o mesmo problema tendências distintas, Sociologia, Problemas e Práticas (87) pp. 71-86.

Easterly, William (2002), The elusive quest for growth: economist's adventures and misadventures in the tropics, Cambridge (M.), MIT Press.

Guerra, Isabel (1994), As pessoas não são coisas que se ponham em gavetas, Sociedade e Território (20), pp. 11-16.

INE (2014), Destaque: rendimento e condições de vida 2013 (dados provisórios), Lisboa, INE. acedido em 22 de setembro de 2020.

INE (2020), Síntese INE@covid-19, Setembro, Lisboa, INE.

Justino, David (2013), Origens sociais, expectativas, oportunidades e desempenho escolar em Portugal. Em Diogo, Ana; e Fernando Diogo (orgs.) (2013), Desigualdades no sistema educativo: percursos, transições e contextos, Lisboa, Mundos Sociais, pp. 7-20.

OECD (2020), Education at a Glance 2020: OECD Indicators, Paris, OECD Publishing.

Rodrigues, Carlos Farinha (coord.); Rita Figueiras; e Vitor Junqueiro (2016), Desigualdade de Rendimento e Pobreza em Portugal 2009-2014, Lisboa, Fundação Francisco Manuel dos Santos.

Sachs, Jeffrey (2017), A era do desenvolvimento sustentável, Lisboa, Atual Editora.

Veiga, Fátima; Paula Cruz; e Elizabeth Santos (2020), O Combate à Pobreza em Contexto da Covid 19. Resultados do Inquérito às Organizações, Porto, EAPN.

Wall, Karin; Ana Nunes de Almeida; Maria Manuel Vieira; Vanessa Cunha (coord.); Leonor Rodrigues; Filipa Coelho; Mafalda Leitão; e Susana Atalaia (2015), Impactos da Crise nas Crianças Portuguesas: Indicadores, Políticas, Representações, Lisboa, ICS. 
Entrevista realizada a Fernando Diogo no âmbito da rubrica "Um olhar sociológico sobre a crise Covid-19", publicada a 11 de maio de 2020.

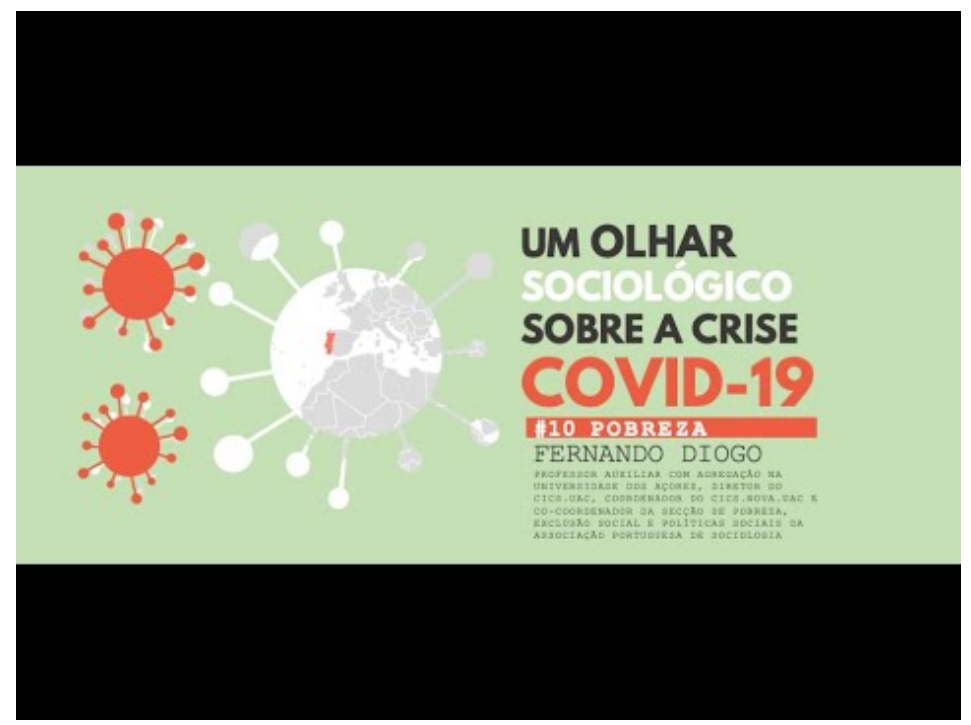




\section{CAPÍTULO 14}

A PANDEMIA NA ACADEMIA: FAZER, E TRANSFORMAR, O TRABALHO CIENTÍFICO EM TEMPOS DE COVID-19

\section{Maria do Mar Pereira}

Professora associada de sociologia na University of Warwick e investigadora no Centro Interdisciplinar de Estudos de Género da Universidade de Lisboa

Quando em junho de 2020 recebi o convite para redigir este texto, com instruções para o enviar até 15 de setembro desse ano, imaginei que ele seria relativamente fácil de escrever. "Em setembro", calculei eu, "será tudo mais calmo. As crianças estarão de regresso à escola, eu voltarei a ter horas de autonomia e espaços de silêncio para ler, pensar e escrever, a poeira da pandemia terá assentado, e a passagem do tempo tornará mais fácil compreender, finalmente, esta experiência extraordinária que estamos a atravessar". Recordando isso agora, dia 11 de setembro, sinto-me embaraçada com a ingenuidade dos meus cálculos, e com o simplismo do meu otimismo. Em ciências sociais é bom ser otimista, sim, mas uma socióloga experiente não devia ser simplista, porque afinal - como se aprende na primeira aula de Sociologia - os processos sociais são sempre complexos. Mas há, desta vez, uma boa justificação para este lapso momentâneo no meu pensamento sociológico - e para todas as centenas de outros lapsos pontuais e prolongados no meu trabalho científico ao longo dos últimos meses... É tudo culpa da pandemia de Covid-19 (doença causada pelo coronavírus SARS-CoV-2). Não estava a pensar direito por causa do caos, exaustão, incerteza, ansiedade e desorientação que a pandemia tem causado em pessoas, comunidades e organizações por todo o mundo. ${ }^{1}$

$1 \bigcirc$ trabalho de investigação apresentado neste texto foi financiado por um Philip Leverhulme Prize, concedido pelo Leverhulme Trust, e por uma Warwick Academic Returners Fellowship, concedida pela Universidade de Warwick. 
É verdade que alguma da poeira inicial da pandemia já assentou, mas vêm aí novos turbilhões. Na manhã em que escrevo estas palavras, anunciaram um novo período de confinamento na região em que resido no Reino Unido. Ontem, a professora do meu filho mais velho começou a ter sintomas de Covid-19 e logo à tarde receberemos os resultados do teste para saber se ela, e toda a turma da escola primária, têm de fazer quarentena. Amanhã, Portugal passará a estar de novo excluído do corredor aéreo com o Reino Unido. Dentro de alguns dias, na data exata em que tenho de submeter a versão final deste texto, Portugal continental entrará em situação de contingência, com a aplicação de novas medidas de restrição da interação e circulação, destinadas a limitar a propagação da Covid-19 depois de, esta semana, se ter registado o maior aumento diário de novas infeções desde abril. No momento em que componho esta frase, já houve em todo o mundo 28.525.510 casos de Covid-19 e mais de 916.000 mortes (Coronavirus Resource Center, 2020). É verdade que com o benefício da passagem do tempo conseguimos compreender melhor os impactos fisiológicos e sociais desta pandemia, mas o futuro próximo - e distante - em termos epidemiológicos e sociológicos parece ainda incerto. É também verdade que já tenho mais horas de autonomia e espaços de silêncio, mas o cérebro ainda não está a funcionar como dantes. Quando tento ler, absorvo pouco porque a cabeça está distraída com uma cacofonia de considerações. Quando tento escrever, fico parada a olhar para o ecrã e os meus dedos ganham vida própria. Em vez de permanecerem em cima do teclado, fogem para o rato, abrem outra janela e começam (outra vez!) a clicar "refresh" numa qualquer página de notícias ou na caixa de correio onde recebo as notificações da escola primária. Acabo, assim, hipnotizada de novo pelas contagens constantes (e crescentes) da Covid-19, nervosamente à espera de novas atualizações sobre eventuais alterações à nossa vida. Pelo menos quando as crianças estavam em casa havia sempre tanto para fazer no imediato que sobrava pouco tempo para a solitária e ansiosa ruminação (Utoft, 2020) que me está a distrair agora. Afinal, este texto não vai ser nada fácil de escrever. 
No fundo, é justo que este texto seja complicado de produzir pois ele analisa, precisamente, as complicações que a Covid-19 veio gerar para a produção científica. As experiências pessoais que descrevo nos parágrafos acima não são estranhas ou excecionais - elas refletem fenómenos e tendências analisados nos muitos estudos e testemunhos publicados sobre este tema nos últimos meses, em vários países e disciplinas. Na próxima secção, uso essa literatura para identificar os impactos que a pandemia tem tido no trabalho académico a nível internacional, com especial atenção para a forma como esses impactos são afetados por desigualdades de género, e afetam, eles próprios, essas desigualdades. Em seguida, contextualizo estes impactos recentes e conjunturais da pandemia em processos mais vastos e antigos de transformação da academia nos países ocidentais, argumentando que muitos dos problemas com que nos confrontamos neste momento não são, de forma alguma, problemas novos ou imprevistos. Concluo o texto olhando para o futuro, refletindo sobre a forma como devemos reorganizar o trabalho académico nos meses e anos que aí vêm, e juntando a minha voz às vozes de muitxs outrxs colegas que propõem que se utilize esta pandemia como oportunidade para transformar as universidades.

O impacto da Covid-19 no trabalho científico e nas desigualdades académicas

Embora tenham passado apenas seis meses desde que a Organização Mundial de Saúde classificou a Covid-19 como uma pandemia, existem já muitos milhares de artigos científicos publicados sobre este vírus, e centenas de textos dedicados especificamente a analisar os efeitos da pandemia no funcionamento das universidades, nas condições de trabalho e aprendizagem no ensino superior, na estrutura das carreiras académicas e nos processos de produção e circulação de conhecimento científico. Esta vasta literatura inventaria um grande conjunto de transformações no trabalho científico nos últimos meses, nomeadamente: 
- transferência massiva e extremamente rápida do trabalho presencial para um regime de teletrabalho (regime que antes da pandemia já era relativamente comum na academia, mas apenas para certas formas de trabalho científico);

- disrupção e reestruturação das atividades letivas a todos os níveis;

- cancelamento, suspensão ou adiamento de um grande número de eventos e processos científicos (como conferências ou exercícios de avaliação e auditoria);

- interrupção ou perturbação do trabalho de investigação devido a níveis mais elevados de doença e ansiedade, ao fechamento das universidades, às restrições à mobilidade, às cargas mais intensas e complexas de cuidado aos mais variados tipos de dependentes e às condições de trabalho menos propícias (por exemplo, com menos acesso a tecnologias, livros e outros materiais, com mais distrações e multi-tasking, em espaços confinados partilhados com outras pessoas);

- surtos de despedimentos e congelamento das contratações e progressão na carreira;

- transformações nos calendários letivos, e nos calendários de candidaturas, execução ou avaliação de bolsas e projetos de investigação;

- alterações no número de candidaturas de alunxs a cursos, com efeitos ao nível dos orçamentos das universidades;

- redução ou redirecionamento do financiamento disponível para certas atividades ou áreas científicas (e consequente aumento do financiamento disponível para outras).

Muitas destas transformações são comuns a várias regiões do mundo, mas todas assumem manifestações e intensidades diferentes em cada contexto, instituição ou disciplina particular.

Essa literatura salienta que apesar destas alterações afetarem uma extraordinária quantidade de pessoas em sistemas académicos por todo o mundo, elas têm impactos muito desiguais em diferentes grupos de pessoas. Sabemos, por exemplo, que quem trabalha em condições contratuais mais precárias tem sofrido um impacto desproporcionalmente negativo, pois muitas universidades estão a 
rescindir contratos ou suspender renovações e contratações como forma de diminuir custos (Castela, 2020; Corbera et al., 2020; Hall, 2020; Shelley-Egan, 2020). Importa, a este nível, salientar que entre xs trabalhadorxs científicxs precárixs registam-se proporções mais elevadas de mulheres, de pessoas racializadas e de jovens do que entre xs trabalhadorxs com contratos permanentes ou de longo-prazo, o que significa que esses impactos negativos estão desigualmente distribuídos. Observa-se também, e previsivelmente, que as disciplinas em que o ensino e a investigação assentam em trabalho presencial e coletivo em espaços concretos e com instrumentos especializados (por exemplo, em laboratórios, hospitais, estúdios ou no terreno) têm sofrido efeitos mais profundos com as medidas de restrição do movimento e interação (Myers et al., 2020). A literatura salienta também os efeitos desproporcionalmente disruptivos sobre o pessoal e estudantes que têm menos acesso aos recursos económicos e tecnológicos substanciais que são necessários para criar em casa condições de teletrabalho académico funcionais e fiáveis (Corbera et al., 2020; Dobusch e Kreissl, 2020). Várixs autorxs argumentam que no início da pandemia (e, em algumas universidades, ainda hoje) se assumiu em muito do discurso coletivo e na política institucional que a transferência de aulas, conferências e encontros para plataformas digitais seria uma medida inclusiva porque essas plataformas digitais, por estarem online, seriam supostamente acessíveis a todxs. No entanto, rapidamente se tornou evidente que existe uma grande quantidade de fatores individuais e estruturais que tornam a participação nessas plataformas difícil ou impossível para muitas pessoas. Esses fatores incluem, por exemplo, condições de habitação, capital económico, acesso aos equipamentos, características das infraestruturas de internet a nível local, regional e nacional, estrutura das famílias, problemas de saúde e deficiência, familiaridade com a tecnologia e à-vontade com comunicação tecnologicamente mediada (Boncori, 2020; Dobusch e Kreissl, 2020; Jenkins, 2020; Malisch et al., 2020; Matthewman e Huppatz, 2020; Nash e Churchill, 2020; Shelley-Egan, 2020). 
Desde o início da pandemia, tem havido na academia e nos meios de comunicação um debate particularmente intenso sobre o carácter genderizado do impacto da Covid-19 no trabalho remunerado em geral e no trabalho científico em particular. $O$ encerramento de muitos locais de trabalho, escolas e jardins-de-infância, e de serviços de apoio a adultos idosos ou dependentes produziu um aumento muito significativo da quantidade e variedade de trabalho doméstico, de cuidados e de ensino a recair sobre as famílias (Abdellatif e Gatto, 2020; Boncori, 2020; Gaspar, 2020; Lopes e Coelho, 2020). A esta carga de cuidado mais intensa juntou-se ainda todo o trabalho adicional de gestão dos impactos da pandemia - cuidar de pessoas doentes, dar apoio material e virtual a pessoas isoladas ou lidar com os obstáculos novos e complexos que a pandemia trouxe à execução de tarefas velhas e habitualmente simples, como comprar comida. Esta transformação significativa, com carácter de emergência, na natureza do trabalho doméstico e de cuidados levou a uma alteração profunda na dinâmica de muitas famílias. Alguns textos reportam, por exemplo, níveis mais altos de participação masculina nestas esferas de trabalho durante a pandemia (Abdellatif e Gatto, 2020; Alon et al., 2020), abrindo a porta e a esperança - a mudanças futuras na organização social e familiar desse tipo de trabalho. Mas num mundo em que o trabalho reprodutivo continua a ser entendido como trabalho feminino, essas novas tarefas recaíram desproporcionalmente sobre as mulheres (Lopes e Coelho, 2020). Isto significa, claro, que entre as mulheres foi, no geral, mais intensa a disrupção profissional causada não só pelo aumento do volume e variedade de trabalho doméstico e de cuidados, mas também pela repentina e radical dissolução das fronteiras espaciais e temporais entre esse trabalho e o trabalho profissional (Boncori, 2020; Cardel et al., 2020; Lopes e Coelho, 2020; Matthewman e Huppatz, 2020). Como escrevem Guy e Arthur, "[n]ow that a worldwide pandemic is upon us, working mothers, particularly in academia, are struggling to keep up with their male counterparts more than ever before" (2020: 887).

É ainda cedo para identificar de forma completa e exaustiva as manifestações e efeitos que estas desigualdades estruturais de género 
terão especificamente no trabalho e carreiras científicas tanto no presente como no futuro. Saberemos muito mais daqui a alguns meses, quando estiverem concluídos vários projetos de investigação em curso sobre estas questões, incluindo em Portugal dois estudos importantes financiados pelo programa FCT-CIG: Gender Research for COVID-19: "SAGE19: Scientific and Academic Gender (in)equality during COVID19", coordenado por Thais França e "Pandemia e Academia em casa - Que Efeitos no Ensino, Investigação e Carreira? Estudo sobre as Mudanças no Sistema Científico e de Ensino Superior", coordenado por Virgínia Ferreira. No entanto, a literatura internacional disponível no momento em que escrevo este texto revela já desigualdades de género concretas e claras, tanto ao nível das estatísticas como ao nível das experiências, devido ao impacto da pandemia.

Estudos internacionais que analisaram o impacto dos primeiros meses da pandemia nas condições de trabalho científico concluem que para muitas pessoas houve uma alteração no número de horas de trabalho possíveis e na distribuição dessas horas por diferentes atividades, mas demonstram que essas alterações apresentam características diferentes para mulheres e homens (Alon et al., 2020; Cardel et al., 2020; Myers et al., 2020). Myers et al. inquiriram em abril de 2020 mais de 4.500 cientistas a trabalhar em universidades na Europa e nos EUA. No seu estudo, 55\% dxs inquiridxs declararam que a pandemia veio reduzir o seu número total de horas de trabalho, 27\% declararam não ter havido alteração, e 18\% passaram a trabalhar mais horas. Esta alteração nas horas de trabalho teve efeitos diferentes em cada área do trabalho científico, e a investigação foi uma das áreas mais negativamente afetadas. Xs inquiridxs reportaram, em média, uma redução de $24 \%$ no número de horas que conseguiam dedicar à investigação. Essa redução foi mais acentuada entre xs cientistas que trabalham em disciplinas que requerem laboratórios e também entre as mulheres (que registaram reduções 5\% maiores do que os homens com perfis idênticos) e entre as pessoas com crianças pequenas (que registaram reduções 17\% maiores). Estes efeitos são cumulativos, portanto as mulheres com crianças pequenas que trabalham em 
disciplinas com investigação laboratorial, por exemplo, são desproporcionalmente prejudicadas.

Com o objetivo de explorar mais a fundo o modo como a pandemia transformou as horas de trabalho das cientistas que são mães, Minello et al. (2020) realizaram (entre março e junho de 2020) entrevistas com 80 mulheres cientistas em Itália e nos EUA com pelo menos uma criança até aos 5 anos. Verificaram que a pandemia veio reestruturar a forma como estas cientistas distribuem o seu tempo por diferentes tarefas científicas. Confrontadas com uma redução do tempo de trabalho disponível, e com a necessidade urgente de adaptar as atividades letivas à nova situação, muitas investiram a maioria do tempo em ensino e administração, e interromperam ou abrandaram a investigação. Mas, segundo este estudo, a falta de tempo não era o único obstáculo à investigação; muitas entrevistadas explicaram também que não tinham o espaço, a energia mental ou a concentração para fazer atividades que exigissem reflexão mais profunda e prolongada. Estes dados são confirmados por outros estudos. Jung (2020), por exemplo, descreve os resultados de um inquérito conduzido em maio de $2020 \mathrm{com}$ quase 2.000 cientistas a trabalhar em universidades nos EUA nas áreas da Biologia, Bioquímica e Engenharia: 49\% das mulheres cientistas inquiridas declararam que o período de confinamento teve um efeito negativo significativo na sua capacidade de concentração em atividades de investigação, mas esse valor foi apenas de $29 \%$ entre os homens inquiridos; $34 \%$ das mulheres disseram que responsabilidades inesperadas de cuidados a outrxs afetaram a sua investigação de forma negativa durante o confinamento, enquanto entre os homens apenas $21 \%$ reportaram o mesmo.

Considerando estes e outros dados, é previsível que a pandemia tenha efeitos diretos, mas desiguais, na capacidade e velocidade de produção de publicações. De facto, esse é um dos principais domínios onde se tem investigado e detetado um aumento das desigualdades de género académicas durante a pandemia. Andersen et al. (2020), por exemplo, analisaram a distribuição de género na autoria de 1.893 artigos sobre Covid-19 publicados entre janeiro e junho de 2020 em 
revistas científicas na área da medicina e verificaram que a proporção de artigos em que a primeira autora é uma mulher desceu 19\% relativamente ao mesmo período no ano anterior. Kitchener (2020) cita dados partilhados nos primeiros meses da pandemia por editorxs de revistas em várias disciplinas. $\bigcirc$ seu artigo demonstra que a situação varia muito consoante a revista e a disciplina, mas há alguns exemplos de diferenças profundas na produtividade de mulheres e homens durante a pandemia: em revistas de astrofísica houve uma diminuição de $50 \%$ no número de artigos submetidos por mulheres durante os primeiros meses da pandemia (quando comparados com os mesmos meses no ano anterior) e há revistas de ciência política que durante a pandemia registaram um aumento de 30\% a 50\% no número de artigos submetidos por homens. Uma das principais revistas australianas em Sociologia, o Journal of Sociology, comparou as submissões de artigos no período de março - maio em 2019 e em 2020 e detetou entre os dois anos um aumento de 12,5\% nas submissões de artigos por homens, mas uma queda de $25 \%$ nos números de artigos submetidos por mulheres (Matthewman e Huppatz, 2020).

Se, como demonstram estes estudos, a pandemia está a ter efeitos desiguais na produtividade, afetando mais negativamente alguns grupos (como as pessoas - e principalmente as mulheres - que têm dependentes a cargo) então é fundamental monitorizar esses efeitos. É também fundamental implementar - a nível institucional, nacional e internacional - políticas de mitigação e compensação dessa desigualdade (Andersen et al., 2020; Cardel et al., 2020; Cui et al., 2020; Malisch et al., 2020). Como escrevem Cardel et al.:

domestic burdens and childcare responsibilities are being amplified during COVID-19 and their combined impact on career productivity and funding acquisition will result in a triple-threat to tenure and/or promotion for early career women. (...) Lack of support and resources for women scientists will lead to a secondary epidemic of lost early career (...) scientists, particularly 
among those already vulnerable to leaks in the academic pipeline (e.g., early career women and women of color) (2020: 3).

A literatura sugere várias medidas diferentes que as instituições científicas podem tomar proativamente nos próximos meses e anos para apoiar pessoas e grupos cujo trabalho tenha sido afetado pela pandemia. As medidas propostas incluem: ajustar os critérios de contratação e promoção nas carreiras científicas e os objetivos de produtividade estabelecidos para indivíduos e equipas; organizar soluções de apoio ao cuidado de crianças ou dar apoio financeiro a trabalhadorxs que têm de assumir custos acrescidos para criar essas soluções; conceder licenças sabáticas adicionais ou mais longas às pessoas responsáveis por dependentes; prolongar o período de duração de bolsas e de projetos financiados; avaliar e reajustar regularmente as políticas de mitigação dos efeitos da pandemia, integrando nesses processos uma atenção explícita ao género e outras desigualdades; produzir estratégias de recuperação da pandemia que incluam planos de ação concretos de combate às desigualdades (de género e outras) geradas ou intensificadas pela pandemia; e comunicar estes problemas e medidas no seio das instituições de forma aberta, regular e transparente, envolvendo uma grande diversidade de colegas na discussão, desenho, implementação e avaliação dessas políticas (Alon et al., 2020; Andersen et al., 2020; Cardel et al., 2020; Lopes e Coelho, 2020; Malisch et al., 2020; Stadnyk e Black, 2020).

Os problemas das nossas perguntas sobre desigualdades no trabalho científico

$\mathrm{Na}$ literatura sobre desigualdades de género no trabalho científico durante a pandemia, dá-se muita atenção a dados relacionados com a publicação de artigos em revistas, por comparação com outros aspetos da atividade académica. Isto pode ser explicado, por um lado, pelo facto de ser relativamente fácil e rápido recolher dados sobre publicação que permitam identificar tendências ao longo do tempo e 
fazer comparações entre grupos de pessoas e entre áreas de estudo. Depois de anos de expansão da metrificação e auditoria na vida académica em Portugal e noutros países (Burrows, 2012; Pereira, 2017, 2018; Santos Pereira, 2020; Shore e Wright, 2000), temos agora na ponta dos dedos os mais variados dados e instrumentos de análise da produtividade em publicações. Esses processos apontam para uma segunda explicação para o grande interesse em analisar, em tempos de pandemia, novas desigualdades de género a nível da produção de publicações. Com a institucionalização em muitos países de sistemas universitários mercantilizados e culturas académicas performativas (Ball, 2000; Bebiano, 2020; Pereira, 2017, 2018, 2019; Sousa, 2020), as publicações assumiram na vida científica um papel cada vez mais central - e desproporcional - como indicador de valor, símbolo de suposta "excelência" e critério de progressão na carreira (Santos Pereira, 2020). Isso significa que alterações, mesmo que pequenas ou temporárias, nas taxas de produtividade em termos de publicações podem ter, a médio ou longo prazo, efeitos diretos na progressão individual na carreira ou na performance bibliométrica de equipas, disciplinas e instituições. Como sugerem já vários estudos (Cardel et al., 2020; Cui et al., 2020; Minello et al., 2020), estes efeitos podem vir a intensificar desigualdades de género (bem como de raça, por exemplo) já existentes nas carreiras científicas, nomeadamente formas de desigualdade salarial e segregação vertical como os chamados "tetos de vidro" e "fugas na canalização" (Comissão Europeia, 2019; Delicado e Alves, 2013).

A Covid-19 gera, como vimos, desigualdades de género na capacidade de produção científica e é importante, pelas razões acima mencionadas, conhecer e combater essas desigualdades... mas pareceme fundamental proceder com atenção na investigação e intervenção nesta área, para evitar abordagens simplistas a fenómenos complexos. Tomar as diferenças entre mulheres e homens ao nível do ritmo de publicação como o elemento ou símbolo mais importante da desigualdade de género na academia em tempos de pandemia (como fazem muitos textos), levanta vários problemas. Nesta secção, quero analisar em detalhe dois exemplos de problemas. 
O primeiro problema é que o enfoque neste tipo de produtividade normaliza e reproduz a fetichização da publicação (e, concretamente, a publicação de artigos em revistas indexadas) como objetivo principal da atividade académica (Santos Pereira, 2020). Esta fetichização parece-me desadequada por duas razões. Por um lado, ela gera a impressão de que a única razão (ou desculpa!) para uma pessoa não conseguir produzir ao ritmo normal durante uma pandemia é a obrigação - muitas vezes genderizada - de tomar conta de dependentes ou de fazer trabalho doméstico. Como perguntam Corbera et al., "[e]ven if the household conditions were more 'favorable', could someone be expected to conduct business-as-usual in the wake of a global pandemic and maintain the same pace of productivity and engagement with our job duties?" (2020: 193). Ahmad (2020) vai ainda mais longe e apela ao abandono de preocupações e desejos de produtividade:

While it may feel good in the moment, it is foolish to dive into a frenzy of activity or obsess about your scholarly productivity right now. That is denial and delusion. (...) [D]enial only serves to delay the essential process of acceptance [of the permanent change caused by the pandemic], which will allow us to reimagine ourselves in this new reality (2020: parág. 3 e 20).

Por outro lado, esta fetichização da publicação como expressão máxima do trabalho científico obscurece outras dimensões cruciais desse trabalho, como o ensino e orientação, o apoio a alunxs, a gestão académica, a comunicação de ciência nos média, escolas e sociedade, ou a trabalho com parceiros e populações fora da academia. Ao privilegiar a análise dessas dimensões quantificáveis, individualizadas, rápidas e produtivas do trabalho académico, reproduzimos a desvalorização destas dimensões mais qualitativas, coletivas, lentas e reprodutivas desse trabalho (Bebiano, 2020; Berg e Seeber, 2016; Branicki, 2020; Cardozo, 2017; Corbera et al., 2020; Guarino e Borden, 2017; Mountz et al., 2015; Pereira, 2017; Stadnyk e Black, 2020). Apesar de pouco reconhecidas formalmente, estas outras dimensões do 
trabalho científico são extremamente importantes, especialmente em tempos de pandemia (e também de intensificação de populismos e preconceitos na sociedade e de agudização de problemas de saúde mental entre estudantes). Tendo em conta tudo isto, quando debatemos o trabalho científico presente e futuro devemos recusar tratar a produtividade como um estado expectável, desejável ou normal em tempos de pandemia, e devemos considerar o impacto da Covid-19 nas diferentes dimensões do trabalho científico.

Um segundo problema com as perguntas mais frequentemente colocadas na literatura sobre desigualdade de género no trabalho científico é que elas tendem a construir o género de forma enviesada e enviesadora. Ao concetualizar a desigualdade de género em tempos de pandemia como uma desigualdade que decorre necessária ou principalmente da desigual divisão entre mulheres e homens do trabalho doméstico e cuidados a dependentes, estamos a fazer várias suposições potencialmente problemáticas. Muita literatura sobre este tema assume, por exemplo, que as pessoas vivem em agregados heterossexuais e duo-parentais, e que todas as pessoas têm identidades de género binárias (isto é, que a população só se divide em mulheres e homens). A literatura assume também que analisar a experiência das mães é equivalente a analisar a experiência das mulheres (o que implica imaginar todas as mulheres como mães) (Utoft, 2020). Como salienta Clancy, "women's academic productivity seems primarily to be discussed in relation to a different kind of productivity motherhood" (2020: 857). Assume-se ainda que todos os homens académicos com crianças beneficiaram da presença em casa de uma mulher durante a pandemia, o que não é verdade em qualquer altura, mas especialmente durante a pandemia da Covid-19, que mobilizou muitxs trabalhadorxs essenciais em setores profundamente feminizados (Abdellatif e Gatto, 2020; Lopes e Coelho, 2020). Finalmente, ao centrar a oposição "mulher (= mãe) interrompida, em estado de subprodução" vs. "homem sem constrangimentos, em estado de sobreprodução", a literatura causa outro problema: ela contribui para reproduzir a ideia de que os homens cientistas, no geral, têm taxas de produção científica 
elevadas e que todos se identificam com um modelo (machista) de masculinidade académica que privilegia níveis elevadíssimos de competitividade, produtividade, individualismo e autoconfiança. No entanto, sabemos que essa não é a experiência, identidade ou prática profissional de muitos homens cientistas, tanto antes como durante a pandemia (Abdellatif e Gatto, 2020; Alcadipani, 2020; Corbera et al., 2020; Hall, 2020; Nash e Churchill, 2020; Pereira, 2018; Santos Pereira, 2020; Sparkes, 2007). Como tal, é importante não representar e normalizar esse modelo como o único modelo existente de masculinidade académica contemporânea.

Todas as suposições acima reproduzem estereótipos antigos de género e sexualidade. Mas elas são problemáticas também por uma outra razão. Uma abordagem que explica as desigualdades científicas de género que estão a emergir com a pandemia em função de fatores externos à academia - como são as dinâmicas genderizadas de gestão doméstica e familiar privada - obscurece as desigualdades que decorrem de fatores internos à academia. Isso inclui, por exemplo, a tendência, observada já em diversas instituições (Boncori, 2020; Flaherty, 2020; Guy e Arthur, 2020; Minello et al., 2020), de atribuir desproporcionalmente às mulheres $\mathrm{o}$ trabalho emocional e material de cuidar do bem-estar de alunxs e colegas durante a pandemia, reduzindo o tempo que elas têm disponível para outras tarefas (como a investigação, mas não só), uma tendência que já se registava, aliás, muito antes da pandemia de Covid-19 (Andersen et al., 2020; Cardozo, 2017; Guarino e Borden, 2017; Pereira, 2017).

Estudar os impactos que a Covid-19 tem tido no trabalho científico e nas desigualdades académicas gera assim alguns desafios complexos. Como medir o trabalho científico que as pessoas estão a fazer durante a pandemia sem reproduzir a ideia de que é possível e desejável continuar a fazer trabalho científico nestas condições extremas e excecionais de ansiedade, enfermidade e mortalidade? Como reconhecer o (evidente) impacto desigual que as obrigações domésticas e familiares têm tido nas condições de trabalho das mulheres, sem reproduzir a ideia de que todas as mulheres têm certas 
obrigações domésticas e familiares? Como denunciar as ameaças à produtividade científica das mulheres cientistas durante a pandemia e exigir melhores condições de produção para elas, sem reproduzir a ideia de que o valor dxs cientistas se mede pela sua produtividade e que a sua produção deve ser protegida e maximizada a qualquer custo?

Perante estes desafios, considero que uma análise das desigualdades de género no trabalho científico durante a pandemia tem de analisar a disrupção desproporcional da produtividade das mulheres, mas deve ao mesmo tempo questionar a comparação e competição em torno da produtividade, recusar o ideal de produtividade elevada e promover outros critérios de valor científico. Em termos mais gerais, eu argumentaria que qualquer debate sobre as condições de trabalho científico durante a pandemia tem de estudar a disrupção do trabalho científico normal, mas deve ao mesmo tempo questionar criticamente esse "normal", rejeitar explicitamente o regresso a ele, e propor ativamente normas de trabalho científico diferentes. Para fazer esse trabalho crítico e criativo, é necessário examinar as nossas práticas de trabalho "normais" (isto é, pré-Covid-19) à luz daquilo que estamos a viver e a aprender com a pandemia.

Problemas velhos ou um mundo novo? Mudança e continuidade no trabalho científico durante a Covid-19

"Sem precedentes". É essa uma das expressões mais recorrentes no discurso diário sobre a Covid-19 em Portugal e outros países. Mas será que no que diz respeito ao trabalho científico, esta é, de facto, uma situação totalmente sem precedentes? O Dicionário Infopédia da Língua Portuguesa (2020) define precedente como "algo que está imediatamente antes", "o modo de viver anterior de um acusado", um "procedimento ou circunstância anteriores que permitem explicar ou autorizar acontecimentos ou circunstâncias análogas". Será verdade que as práticas de trabalho que observamos hoje não existiam "imediatamente antes" da Covid-19, não faziam parte do nosso "modo de viver anterior" nas universidades? É correto afirmar que não havia, 
nas formas de trabalho científico anteriores à pandemia, "procedimento[s] ou circunstância[s] que permitem explicar ou autorizar" o modo como estamos a trabalhar agora?

Esta pandemia constitui, claro, um fenómeno raro e excecional, que está a criar problemas novos para as universidades e outras organizações científicas. Não obstante esse facto, várixs autorxs têm argumentado que devemos analisar muitas das práticas e desigualdades de trabalho científico emergentes durante a pandemia não como uma realidade nova, ou rutura completa, mas sim como uma agudização e generalização de tendências já presentes há vários anos (Corbera et al., 2020; Hall, 2020). Estes tempos de crise são tempos de mudança, sim, mas - como tantas outras crises (Branicki, 2020) - são também tempos de muitas continuidades. Como argumentam Pereira et al. (2020), quando falamos sobre os desafios causados pela pandemia como um estado excecional e imprevisível, invisibilizamos os problemas estruturais antigos e as políticas e práticas passadas que estão na base desses novos desafios. Estas autoras argumentam, por isso, que é necessário "[c]olocar a ênfase nas políticas dos tempos de «normalidade» e nas suas consequências na gestão de políticas de tempos de exceção" (Pereira et al., 2020: 16). É isso que procuro fazer nesta secção, recorrendo a três exemplos: o espaço e o tempo do trabalho científico, a conciliação do trabalho científico com a vida pessoal e as experiências de desgaste e doença no trabalho científico.

Nas secções acima referi que a pandemia veio dissolver as fronteiras espaciais e temporais em torno do trabalho científico, pondo-nos a fazer e ensinar ciência em casa, a qualquer hora do dia (Boncori, 2020). Mas há já muitos anos que se fala na literatura da colonização do espaço e tempo privado pelo trabalho científico (Pereira, 2017; Weeks, 2011) e do facto de xs cientistas sentirem que não têm tempo suficiente para completar todo o trabalho que há para fazer (Araújo, 2016; Gill, 2010). Considere-se, por exemplo, este parágrafo retirado de um texto que publiquei há quase 10 anos (Pereira, 2011: 8): 
Uma das tendências de mudança [no trabalho científico no século XXI] é a extensificação (Gill, 2010; Jarvis e Pratt, 2006) e elastização (Lynch, 2010: 57) do tempo e espaço de realização do trabalho científico. Adaptando o conceito de "fábrica sem paredes" de Antonio Negri (1989), Rosalind Gill argumenta que trabalhamos actualmente numa "academia sem paredes" (Gill, 2010: 237). Graças ao acentuado desenvolvimento das tecnologias de comunicação e informação, qualquer local e momento pode em princípio servir para realizar actividades académicas. Para além disso, a actual carga de trabalho média nas universidades é de tal forma intensa que só é possível completar todas as funções pedagógicas, de investigação e administrativas trabalhando também de noite, aos fins-desemana e feriados, e/ou nas férias (Butterwick e Dawson, 2005). Dissolvem-se assim as fronteiras entre espaço/tempo de trabalho e espaço/tempo de lazer, e as/os investigadoras/es passam a estar sempre potencialmente "on", contactáveis e de serviço (Alvanoudi, 2009; Fantone, 2007).

Esta descrição podia ter sido escrita sobre o ano de 2020, tais são as semelhanças com as experiências que estamos a viver agora e com a linguagem que usamos para as narrar.

Vimos também acima que a pandemia está a causar profundas dificuldades de conciliação entre trabalho científico e responsabilidades familiares para muitas pessoas. Mas esse também não é um problema inteiramente novo para muitas pessoas que trabalham e estudam em universidades. Há muitos anos que temos de gerir os efeitos, por exemplo, de escolas encerradas ou de vírus transmitidos entre crianças. Eu própria já dei aulas com um bebé às costas (ele estava com diarreia e, portanto, foi excluído da creche durante 48 horas, caso tivesse um vírus contagioso) e fiz comunicações em conferências com uma criança sentada ao meu lado, no pódio, a pintar (estávamos em período de férias e a escola estava fechada). A literatura produzida sobre estas experiências denuncia há muitos anos os impactos negativos que esses 
desafios de conciliação (distribuídos de forma profundamente desigual em termos de género) têm no bem-estar, na capacidade de trabalho, na mobilidade académica e na progressão de carreira dxs cientistas (Andersen et al., 2020; Burk et al., 2020; Cardel et al., 2020; Henderson e Moreau, 2020).

Nas secções acima identifiquei um terceiro impacto da pandemia: o facto de nos últimos meses as pessoas que trabalham e estudam nas universidades (Marelli et al., 2020) estarem a fazer esse trabalho em condições de grande distração, desgaste e doença, e num estado de profunda "insegurança ontológica" (Wright et al., 2020). Estado esse que é particularmente profundo para aquelas pessoas que fazem parte de grupos mais vulneráveis aos efeitos da Covid-19, nomeadamente pessoas racializadas, mais velhas ou com doenças crónicas e deficiências. É evidente que a extensão e severidade desses problemas não tem precedentes no passado recente... Mas a distração, desgaste e doença já faziam parte do "nosso modo de viver anterior" na academia. As pessoas que trabalham e estudam nas universidades sempre tiveram capacidades e energias limitadas, e sempre tiveram deficiências e problemas de saúde física e mental. No entanto, essa vulnerabilidade traço humano mais do que antigo - nem sempre foi explicitamente reconhecida e adequadamente salvaguardada pelas instituições científicas em Portugal e noutros países, que tendem a concetualizar o trabalho científico como trabalho intelectual, separado do corpo. Essa é, aliás, uma das causas da subalternização passada (e também presente) das mulheres (ou das pessoas racializadas) na ciência: elas foram, e às vezes ainda são, entendidas como sujeitos muito mais determinados pelo corpo, e muito mais limitados pelas suas supostas funções biológicas e reprodutivas, do que os homens (e as pessoas brancas) (Code, 1991; França, 2016).

Para além de nem sempre reconhecer o desgaste, doença e deficiência que os indivíduos trazem consigo para a academia, a vida académica também contribui muitas vezes para causar desgaste, doença e deficiência, especialmente nas duas últimas décadas. A institucionalização de culturas académicas performativas produziu várias 
transformações no trabalho científico - por exemplo, precarização, maiores exigências de produtividade ou novos regimes de auditoria e avaliação - que nos últimos anos têm causado entre cientistas não só problemas de stress e ansiedade, mas também várias outras doenças e perturbações de saúde física e mental, algumas delas graves e às vezes fatais (Gill, 2010; Hall, 2020). A situação é tão séria em alguns países que há autorxs que a descrevem há já vários anos como "a psychosocial and somatic catastrophe in universities" (Gill e Donaghue, 2016: 91) ou como uma "deep, affective, somatic crisis [that] threatens to overwhelm us" (Burrows, 2012: 355). De facto, podemos dizer que já existia um estado de crise de saúde na academia muito antes da pandemia. Verificam-se fenómenos semelhantes em Portugal; considere-se, por exemplo, este excerto de uma entrevista que fiz a uma investigadora em ciências sociais numa universidade portuguesa (analisado em detalhe em Pereira, 2017, 2019):

Entrevistada: [As transformações recentes na academia] mexeram com as pessoas no mais profundo do seu íntimo. (...) MMP: Outras pessoas têm-me dito que notam uma, como hei-de dizer, não vou dizer depressão, é uma palavra muito forte, mas um estado...

Entrevistada: Mas podes dizer depressão, porque em alguns casos foi mesmo isso. (...) Nota-se perfeitamente que as pessoas, no dia-a-dia, (...) andam mais ansiosas, depressivas, (...) pessoas com problemas de saúde física, dor crónica, necessidade de medicação para dormir (...). Convives com as pessoas e sentes que elas andam sempre no limite das suas forças e capacidade, andam a arrastar-se, (...). Têm sempre a sensação que estão a correr, a correr, sem saber bem para onde, percebes? (...) Isto afeta o ambiente, afeta a vontade das pessoas de conviverem porque o cansaço instala-se e é generalizado e sente-se no ar. 
Muita gente dentro da comunidade científica reconhece que estes problemas existem, discute-os informalmente, e é afetada direta ou indiretamente por eles. Mas apesar de estes problemas serem, como diz a entrevistada, "generalizados", eles continuam a ser explícita ou implicitamente entendidos em muita política institucional e discurso oficial em Portugal como problemas individuais. Na cultura académica dominante, tendemos a ver o desgaste, a doença e a deficiência como fragilidades pessoais, desequilíbrios indesejáveis e algo embaraçosos que devem ser geridos de forma relativamente privada por cada indivíduo recorrendo a soluções individuais (como consultar profissionais de saúde para arranjar terapia ou tratamento; procurar técnicas e tecnologias para tornar o trabalho mais produtivo; gerir melhor o tempo e o e-mail; ou fazer massagens ou meditação) (Gill, 2010; Gill e Donaghue, 2016). Normaliza-se, assim, a expectativa individualista e neoliberal de que cientistas (e também estudantes, outro pessoal universitário e profissionais de tantos outros setores) trabalhem como máquinas, sempre a funcionar, sempre com energia, sempre passiveis de upgrade para produzirem ainda mais e melhor (Gill, 2010; Scharff, 2016). Ninguém consegue, como é óbvio, corresponder sempre e totalmente a este ideal, portanto ele é potencialmente tóxico para toda a gente; mas ele prejudica e exclui, em particular, as pessoas com deficiência e xs trabalhadorxs cuja saúde e situação pessoal (nomeadamente as responsabilidades familiares e domésticas) não Ihes permitem encaixar tão facilmente nos modelos muito restritivos que esta cultura valoriza. Como concluí no meu estudo etnográfico longitudinal da academia portuguesa (Pereira, 2017, 2018, 2019), esta cultura cria nas universidades um clima doente e doentio. Isso significa que já antes da pandemia muitxs cientistas trabalhavam e estudavam em Portugal em estado de crise e em condições de enfraquecimento e adoecimento, num regime que não era, de modo algum, sustentável em termos de saúde.

Os três exemplos que discuti nesta secção demonstram que em muitos aspetos do trabalho científico, a pandemia não veio trazer problemas completamente novos, mas sim aumentar o grau de 
disrupção causado por esses problemas e distribuir os seus efeitos disruptivos de forma mais generalizada (embora ainda desigual), afetando uma maior quantidade (e variedade) de pessoas. Esse aumento da severidade e incidência destes problemas gerou, por sua vez, algumas mudanças importantes. Por um lado, essa maior severidade e incidência veio pôr em primeiro plano o carácter coletivo e estrutural destes problemas antigos (e, até agora, privatizados) de extensificação, conciliação e desgaste. De repente, eles já não são, afinal, apenas problemas de mulheres, ou problemas de pessoas que não têm tanta dedicação ou "estaleca" para o trabalho científico, ou pessoas com doenças ou com deficiência. Por outro lado, essa maior severidade e incidência causou a interrupção da atividade científica "normal". A suspensão da "lufa-lufa" (Pais, 2010) científica quotidiana não só criou espaço e tempo para questionar a "ordem natural das coisas", como também tornou esse questionamento mais urgente e público, obrigando comunidades e instituições a confrontar problemas estruturais que há muito varriam para debaixo do tapete.

Isto significa que em tempos de pandemia estamos a lidar com problemas antigos, mas num contexto radicalmente diferente. Temos agora um contexto de muito maior consciencialização, reflexão e mobilização. Trata-se também de um contexto em que as instituições são obrigadas a fazer reestruturação e, portanto, há mais portas abertas à transformação e, como tal, mais potencial para implementar as mudanças ao trabalho científico que muitxs colegas exigem há tanto tempo (Bebiano, 2020; Berg e Seeber, 2016; Ferreira, 2018; Gill, 2010; Mountz et al., 2015; Pereira, 2017, 2018; Santos Pereira, 2020). Infelizmente, essa janela de oportunidade é curta. Apesar de estarmos, supostamente, às portas de uma segunda vaga da Covid-19 e muita gente estar ainda a recuperar do choque físico, mental e emocional da pandemia (Guy e Arthur, 2020), há muitas universidades em Portugal e noutros países que começam a fechar de novo os olhos à vulnerabilidade de pessoal e estudantes e que exigem já um regresso à normalidade (isto é, um regresso ao campus, à produtividade elevada, à 
disponibilidade constante) (Anónimx, 2020; Bebiano, 2020; Hall, 2020; Vale de Almeida, 2020).

No contexto britânico, esse regresso é frequentemente motivado e justificado por motivos financeiros. Num sistema mercantilizado em que as universidades são negócios que têm de dar lucro, e muito desse lucro vem das rendas pagas em residências de estudantes ou do consumo nos cafés e restaurantes geridos pelas universidades, a necessidade de reanimar a economia do campus torna-se tão, ou mais importante, como fator de gestão da pandemia quanto as considerações pedagógicas, científicas ou de saúde (Anónimx, 2020). Este exemplo demonstra bem os riscos da mercantilização do ensino superior e a necessidade de a combater em países - como Portugal em que essas tendências, embora presentes, não estão ainda tão avançadas. Na academia portuguesa haverá outras motivações para a exigência de regresso ao campus: quem sabe, talvez, "uma certa mentalidade patronal que mede o valor do trabalho, neste caso o dos docentes, pela presença física, imaginando a ausência como lazer" ou a vontade de fazer "«realidade por decreto», parte do desejo de [repor a] "normalidade»" (Vale de Almeida, 2020: parág. 8 e 9), um desejo defensivo que tantas vezes guia a reação de comunidades e instituições quando confrontadas com mudança social rápida ou intensa (Branicki, 2020; Faludi, 1993). Perante esta pressão para voltar depressa a uma "normalidade" de trabalho científico que já tinha efeitos nocivos (para a saúde, o ensino, a produção de conhecimento ou a igualdade) ainda antes de haver Covid-19, temos de agir de forma rápida, reflexiva e coletiva. Só assim conseguiremos aproveitar esta extraordinária janela de oportunidade para criar novas normas, e normalidades, de trabalho científico. Como demonstro na secção seguinte, as experiências da pandemia podem ajudar-nos a identificar princípios orientadores desse novo "normal". 
O futuro do trabalho científico depois da Covid-19: criando um novo normal

Segundo Branicki, as estratégias dominantes de gestão de crises enfatizam a medição de custos e benefícios e a implementação de práticas que têm como objetivo repor o estado original da comunidade ou instituição afetada pela crise. "In contrast, a feminist [approach to] crisis management might emphasize a relational logic grounded in preserving and extending relationships during a crisis through caring, and seeking opportunities for a crisis to lead to a social transformation" (2020: 880). É esta abordagem assente na crítica e no cuidado que eu proponho que adotemos neste período de crise na comunidade académica em Portugal.

Para recuperar não só dos impactos disruptivos recentes da pandemia, mas também dos efeitos tóxicos antigos dos regimes científicos performativos, temos agora de construir culturas académicas guiadas por uma ética do cuidado (Bebiano, 2020; Pereira, 2017, 2018, 2019). Segundo Bebiano, isso implica uma prática científica assente "na construção coletiva e solidária do conhecimento; na solidariedade humana"; no trabalho em ritmo mais lento "com tempo para ter conversas «inúteis», para o riso e para o choro (...) [de forma a] pode[r] devolver o humano à academia" (2020: 13). Para construir essa cultura, que tem também de ser inclusiva e igualitária, podemos usar como ponto de partida, motivação e modelo algumas das experiências causadas pela pandemia: por exemplo, a constatação da nossa vulnerabilidade (física, emocional, social, institucional, etc.) (De Coster, 2020; Guy e Arthur, 2020); a consciência das relações de interdependência que nos ligam a outras pessoas (relações tantas vezes invisibilizadas num regime que assume que os sujeitos são autónomos e que o sucesso é individual) (Clavijo, 2020; De Coster, 2020; Dobusch e Kreissl, 2020; Pereira et al., 2020); a compreensão do impacto e importância do corpo e das emoções (e do seu bem-estar) no trabalho científico (Bebiano, 2020; Clavijo, 2020); os laços de solidariedade gerados pela experiência coletiva de adversidade (Boncori, 2020; 
Matthewman e Huppatz, 2020); a criatividade gerada por uma crise que veio demonstrar que outras práticas e relações são possíveis (Matthewman e Huppatz, 2020); e a consciência da importância que o chamado trabalho doméstico académico (e as pessoas que o fazem) tem no funcionamento das universidades (Motta, 2020). Promover uma ética do cuidado implica, na prática, transformar uma série de práticas e procedimentos, como por exemplo:

prioritizing collective rather than individual goals (...). This means paying increased attention to teaching, mentoring and supporting students; (re-)designing research projects in ways that are more socially meaningful, environmentally sustainable and less stressful for those involved; and contributing to institutional initiatives aimed at fostering collegiality and collective support. This should also involve prioritizing tasks where we can really make a difference, writing less but better, avoiding as much as possible a hectic race for new projects and articles, and engaging more seriously with knowledge transfer to civil society and policy change activities. (...) When the COVID-19 crisis fades away, which it will, we have a chance to make academia a more ethical, empathetic, and thus rewarding profession (Corbera et al., 2020: 193-195).

Segundo Branicki (2020), a reorganização das interações e do trabalho com base na ética do cuidado tem, de facto, impactos muito recompensadores nos indivíduos e comunidades; mas ela tem também efeitos positivos no funcionamento das organizações, tornando-as mais resilientes e dinâmicas, e aumentando a "sustentabilidade organizacional".

Sustentabilidade é, aliás, um termo que aparece com frequência na literatura sobre o futuro do trabalho científico depois da pandemia. Muitxs autorxs argumentam que esse futuro deve ser orientado não só pela ética do cuidado, mas também por uma ética de sustentabilidade. Isto é importante não só porque ainda vamos sentir as repercussões da 
Covid-19 durante muito tempo, mas também porque as pandemias e outras crises são cíclicas e arriscam tornar-se mais regulares nesta época de catástrofe climática. A literatura convida-nos a entender a sustentabilidade académica de forma muito lata e implementá-la a vários níveis. Durante os períodos de confinamento, fomos forçadxs a experimentar formas de trabalho virtual que não só permitem ultrapassar alguns dos constrangimentos da distância física (possibilitando a colaboração com pessoas que estão mais distantes ou que não se podem deslocar facilmente) mas que também são menos nocivas para o ambiente (Shelley-Egan, 2020). Esta repentina "desnormalização" (Shelley-Egan, 2020) da mobilidade aérea, dos grandes congressos e de outras práticas muito intensivas em termos de emissão de carbono pode, e deve, ser o incentivo que faltava para reestruturar as práticas e valores do trabalho científico de forma a tornálo mais sustentável em termos ambientais e climáticos (Corbera et al., 2020).

Para além da sustentabilidade ambiental, é também necessário promover a sustentabilidade humana, o que implica garantir condições de trabalho e de vida sustentáveis, nomeadamente em termos de saúde (por exemplo, abandonando normas e práticas tóxicas de trabalho excessivo) e em termos financeiros (por exemplo, reduzindo a precariedade e a "temporariedade competitiva" (Castela, 2020: 57) do trabalho científico) (Connell, 2020; Corbera et al., 2020). Urge também combater as tendências de mercantilização do ensino superior que muitas vezes comprometem a sustentabilidade financeira das universidades e a sua capacidade de resistir aos choques e pressões causados por crises como a da pandemia da Covid-19 (Anónimx, 2020; Hall, 2020). Além disso, é crucial promover a sustentabilidade intelectual e, no caso específico da Sociologia, a sustentatibilidade e renovação da imaginação sociológica. Muitxs autorxs argumentam que temos de adaptar e revitalizar teorias, conceitos e métodos de investigação para conseguir compreender a pandemia e o mundo que dela vai resultar (Corbera et al., 2020; Matthewman e Huppatz, 2020; Shelley-Egan, 
2020). Refletindo sobre as transformações que são necessárias na Sociologia, Connell escreve:

There is no quick fix. I don't have a clear picture of the path sociologists should follow and I don't know anyone who does. (...) Perhaps it will be important to publish less and so free up more time for sustained thought. (...) This will need collective action. (...) If we can develop sociologies adequate to the moment of COVID-19, they are likely to involve scary leaps beyond our current rules of sociological method. They are likely to be connected with, perhaps embedded in, forms of social action beyond those familiar today. (...) Quite simply, we need more imaginative social thinking, especially about the new structures of power, and new means of change and ways of organizing (2020: 6).

Transformar o pensamento sociológico, o trabalho científico e, claro, transformar o mundo, não será fácil, especialmente numa altura em que muitos dos nossos corpos, cérebros e comunidades estão desgastados e sobrecarregados. Por isso mesmo, conseguir estas transformações vai levar muito tempo. Também para mim levou muito tempo - bem mais do que previa - escrever este texto. Depois de vários dias de trabalho constrangido e interrompido - por crianças, compromissos e desassossego com o que se passa nas notícias - estou agora, finalmente, a acabar o texto, cinco dias depois do prazo que me foi dado para o entregar. À medida que foi aumentando o número de páginas escritas dentro do documento, foram crescendo lá fora os números da Covid-19: neste momento, já houve 30.911 .999 casos e 959.059 mortes (Coronavirus Resource Center, 2020). Mas apesar de ter demorado tanto tempo, o processo de escrita deste texto acabou por ser menos difícil e mais inspirador do que eu esperava, precisamente por causa do cuidado, da cooperação e da colegialidade. Ao ler as análises de tanta gente espalhada pelo mundo, discutir ideias face-aface (na mesa da sala) e ecrã-a-ecrã (em salas de zoom) e "ter conversas 
«inúteis»" e "lentas", cheias de "riso e (...) choro" com colegas e alunxs (Bebiano, 2020: 13), reencontrei muita vitalidade e uma poderosa sensação de comunidade. ${ }^{2}$ Esse "novo" normal que queremos construir não precisa de ser inventado - ele já existe aqui e já existe agora... só resta, então, torná-lo a norma, usando a nossa capacidade de crítica e de cuidado.

\section{Referências bibliográficas}

Abdellatif, Amal; e Mark Gatto (2020), "It's OK Not To Be OK: Shared Reflections from Two PhD Parents in a Time of Pandemic", Gender, Work \& Organization, 27 (5), pp. 723-733.

Ahmad, Aisha S., (2020), "Why You Should Ignore All That Coronavirus-Inspired Productivity Pressure", The Chronicle of Higher Education, 16/03/2020.

Alcadipani, Rafael (2020), "Pandemic and Macho Organizations: Wake-up Call or Business as Usual?", Gender, Work \& Organization, 27 (5), pp. 734-746.

Alon, Titan; et al. (2020), "The Impact of Covid-19 on Gender Equality", Covid Economics, 4.

Alvanoudi, Angeliki (2009), "Teaching Gender in the Neoliberal University" em D. Gronold, et al. (orgs.), Teaching with the Third Wave: New Feminists'

\footnotetext{
2 Muitas das ideias desenvolvidas neste texto foram inspiradas pelo excelente debate com Thais França, Virgínia Ferreira, Lígia Amâncio, Beatriz Padilla, Tiago Santos Pereira, Luísa Winter e outrxs colegas durante a videoconferência "Velhas Desigualdades, Novos Desafios: Género, COVID-19 e Academia" (15 de setembro de 2020); quero agradecer às organizadoras por me terem convidado para participar neste evento, por terem partilhado as suas análises da Covid-19 e pelo trabalho que estão a fazer para desenvolver investigação sobre estes temas em Portugal. A escrita do texto também beneficiou de imensas conversas úteis, e também "inúteis", com Jonathan Dean, Liliana Azevedo, Mia Liinason, Nickie Charles, Caroline Wright, Sara Bamdad, Rose Ernst, Sofia Martinho, Paulina Mata e Violeta Pereira; muito obrigada! Agradeço especialmente ao Renato Miguel do Carmo, Inês Tavares e Ana Filipa Cândido por me terem convidado para fazer este texto, por aguardarem por ele com tanta paciência e o lerem com tanto cuidado, e por assim me terem permitido descobrir que afinal é possível fazer Sociologia no meio de uma pandemia.
} 
Explorations of Teaching and Institutional Contexts, Utrecht, ATHENA, pp. 37-54.

Andersen, Jens Peter; et al. (2020), "Covid-19 Medical Papers Have Fewer Women First Authors Than Expected", eLife, 9, artigo e58807.

Anónimx (2020), "Universities are Being Forced to Lie About Being COVID Safe", openDemocracy, 10/09/2020.

Araújo, Emília Rodrigues (2016), "Uma Abordagem sobre o Tempo de(Para) na Ciência e Academia", Sociologia On-line, 12, pp. 110-136.

Ball, Stephen J. (2000), "Performativities and Fabrications in the Education Economy: Towards the Performative Society?", The Australian Educational Researcher, 27 (2), pp. 1-23.

Bebiano, Adriana (2020), "Academia e Ética do Cuidado" em J. Reis (org.), Palavras para Além da Pandemia: Cem Lados de uma Crise, Coimbra, Centro de Estudos Sociais, p. 13.

Berg, Maggie; e Barbara Seeber (2016), Slow Professor: Challenging the Culture of Speed in the Academy, Toronto, University of Toronto Press.

Boncori, Ilaria (2020), "The Never-Ending Shift: a Feminist Reflection on Living and Organizing Academic Lives During the Coronavirus Pandemic", Gender, Work \& Organization, 27 (5), pp. 677-682.

Branicki, Layla J. (2020), "COVID-19, Ethics of Care and Feminist Crisis Management", Gender, Work \& Organization, 27 (5), pp. 872-883.

Burk, Brooke N.; et al. (2020), "Pandemic Motherhood and the Academy: a Critical Examination of the Leisure-Work Dichotomy", Leisure Sciences, online before print.

Burrows, Roger (2012), "Living with the H-Index? Metric Assemblages in the Contemporary Academy", The Sociological Review, 60 (2), pp. 355-372.

Butterwick, Shauna; e Jane Dawson (2005), "Undone Business: Examining the Production of Academic Labour", Women's Studies International Forum, 28 (1), pp. 51-65.

Cardel, Michelle I.; et al. (2020), "Preventing a Secondary Epidemic of Lost Early Career Scientists: Effects of COVID-19 Pandemic on Women with Children", Annals of the American Thoracic Society, online before print. 
Cardozo, Karen (2017), "Academic Labor: Who Cares?", Critical Sociology, 43 (3), pp. $405-428$.

Castela, Tiago (2020), "Emprego Académico" em J. Reis (org.), Palavras para Além da Pandemia: Cem Lados de uma Crise, Coimbra, Centro de Estudos Sociais, p. 57.

Clancy, Annette (2020), "On Mothering and Being Mothered: a Personal Reflection on Women's Productivity during COVID-19", Gender, Work \& Organization, 27 (5), pp. 857-859.

Clavijo, Nathalie (2020), "Reflecting upon Vulnerable and Dependent Bodies during the COVID-19 Crisis", Gender, Work \& Organization, 27 (5), pp. 700-704.

Code, Lorraine (1991), What Can She Know?: Feminist Theory and the Construction of Knowledge, Ithaca, Cornell University Press.

Comissão Europeia (2019), She Figures 2018, Luxemburgo, Publications Office of the European Union.

Connell, Raewyn (2020), "COVID-19/Sociology", Journal of Sociology, online before print.

Corbera, Esteve; et al. (2020), "Academia in the Time of COVID-19: Towards an Ethics of Care", Planning Theory \& Practice, 21 (2), pp. 191-199.

Coronavirus Resource Center (2020), COVID-19 Dashboard, Center for Systems Science and Engineering - Johns Hopkins University.

Cui, Ruomeng; et al. (2020), Gender Inequality in Research Productivity During the COVID-19 Pandemic, SSRN.

De Coster, Marjan (2020), "Towards a Relational Ethics in Pandemic Times and Beyond: Limited Accountability, Collective Performativity and New Subjectivity", Gender, Work \& Organization, 27 (5), pp. 747-753.

Delicado, Ana; e Nuno de Almeida Alves (2013), " «Fugas de Cérebros», «Tetos de Vidro» e "Fugas na Canalização»: Mulheres, Ciência e Mobilidade" em E. Araújo; et al. (orgs.), Para um Debate sobre Mobilidade e Fuga de Cérebros, Braga, Centro de Estudos de Comunicação e Sociedade (Universidade do Minho), pp. 8-31.

Dicionário Infopédia da Língua Portuguesa (2020), Precedente. 
Dobusch, Laura; e Katharina Kreissl (2020), "Privilege and Burden of Im-/mobility Governance: on the Reinforcement of Inequalities during a Pandemic Lockdown", Gender, Work \& Organization, 27 (5), pp. 709-716.

Faludi, Susan (1993), Backlash: the Undeclared War Against Women, London, Vintage.

Fantone, Laura (2007), "Precarious Changes: Gender and Generational Politics in Contemporary", Feminist Review, 87, pp. 5-20.

Ferreira, Virgínia (2018), Estudos sobre as Mulheres, de Género e Feministas: Visibilidade versus Legitimação, comunicação apresentada na Conferência "Mujeres Investigadoras e Investigación sobre Mujeres en las Universidades Ibéricas", Salamanca.

Flaherty, Colleen (2020), "Early Journal Submission Data Suggest COVID-19 is Tanking Women's Research Productivity", Inside Higher Education, 21/04/2020.

França, Thais (2016), "Mulheres, Imigrantes e Acadêmicas: Teorias da Interseccionalidade para Pensar a Mobilidade Científica", Tomo, 28 (Jan/ Jun), pp. 203-240.

Gaspar, Maria Filomena (2020), "Parentalidade" em J. Reis (org.), Palavras para Além da Pandemia: Cem Lados de uma Crise, Coimbra, Centro de Estudos Sociais, p. 76.

Gill, Rosalind (2010), "Breaking the Silence: the Hidden Injuries of the Neoliberal University" em R. Ryan-Flood, e R. Gill (orgs.), Secrecy and Silence in the Research Process: Feminist Reflections, Abingdon, Routledge, pp. 228-244.

Gill, Rosalind; e Ngaire Donaghue (2016), "Resilience, Apps and Reluctant Individualism: Technologies of Self in the Neoliberal Academy", Women's Studies International Forum, 54, pp. 91-99.

Guarino, Cassandra; e Victor Borden (2017), "Faculty Service Loads and Gender: Are Women Taking Care of the Academic Family?", Research in Higher Education, 58, pp. 672-694.

Guy, Batsheva; e Brittany Arthur (2020), "Academic Motherhood During COVID-19: Navigating our Dual Roles as Educators and Mothers", Gender, Work \& Organization, 27 (5), pp. 887-899. 
Hall, Richard (2020), "Covid-19 and the Hopeless University at the End of the End of History", Postdigital Science and Education, online before print.

Henderson, Emily F.; e Marie-Pierre Moreau (2020), "Carefree Conferences? Academics with Caring Responsibilities Performing Mobile Academic Subjectivities", Gender and Education, 32 (1), pp. 70-85.

Jarvis, Helen; e Andy C. Pratt (2006), "Bringing it All Back Home: the Extensification and "Overflowing» of Work: the Case of San Francisco's New Media Households", Geoforum, 37 (3), pp. 331-339.

Jenkins, Fiona, (2020), "Did our Employers just Requisition our Homes?", Canberra Times, 04/04/2020.

Jung, Heyjie (2020), COVID-19 Stay-at-Home Orders Worsen Academic Scientists' Home-Life: Women Experience More Difficulties, SSRN.

Kitchener, Caroline, (2020), "Women Academics Seem to be Submitting Fewer Papers During Coronavirus", The Lily, 24/04/2020.

Lopes, Mónica; e Lina Coelho (2020), "(Des)lgualdades entre Mulheres e Homens" em J. Reis (org.), Palavras para Além da Pandemia: Cem Lados de uma Crise, Coimbra, Centro de Estudos Sociais, p. 43.

Lynch, Kathleen (2010), "Carelessness: a Hidden Doxa of Higher Education", Arts and Humanities in Higher Education, 9 (1), pp. 54-67.

Malisch, Jessica L.; et al. (2020), "In the Wake of COVID-19, Academia Needs New Solutions to Ensure Gender Equity", Proceedings of the National Academy of Sciences, 117 (27), pp. 15378-15381.

Marelli, Sara; et al. (2020), "Impact of COVID-19 Lockdown on Sleep Quality in University Students and Administration Staff", Journal of Neurology, online before print.

Matthewman, Steve; e Kate Huppatz (2020), "A Sociology of Covid-19", Journal of Sociology, online before print.

Minello, Alessandra; et al. (2020), "The Pandemic and the Academic Mothers: Present Hardships and Future Perspectives", European Societies, online before print.

Motta, Sara C. (2020), "F*** Professionalism: or Why We Cannot Return to 'Normal' ", Gender, Work \& Organization, 27 (5), pp. 868-871. 
Mountz, Alison; et al. (2015), "For Slow Scholarship: A Feminist Politics of Resistance through Collective Action in the Neoliberal University", ACME, 14 (4), pp. 1235-1259.

Myers, Kyle R.; et al. (2020), "Unequal Effects of the COVID-19 Pandemic on Scientists", Nature Human Behaviour, 4 (9), pp. 880-883.

Nash, Meredith; e Brendan Churchill (2020), "Caring during COVID-19: a Gendered Analysis of Australian University Responses to Managing Remote Working and Caring Responsibilities", Gender, Work \& Organization, 27 (5), pp. 833-846.

Negri, Antonio (1989), The Politics of Subversion: A Manifesto for the 21st Century, Cambridge, Polity Press.

Pais, José Machado (2010), Lufa-Lufa Quotidiana: Ensaios sobre Cidade, Cultura e Vida Urbana, Lisboa, Imprensa de Ciências Sociais.

Pereira, Ana Cristina; et al. (2020), "Analogia entre Pandemia e Guerra" em J. Reis (org.), Palavras para Além da Pandemia: Cem Lados de uma Crise, Coimbra, Centro de Estudos Sociais, p. 16.

Pereira, Maria do Mar (2011), "Activismo na «Academia sem Paredes»: (Im)possibilidades de Intervenção Política em Tempos de Performatividade e Precariedade", LES Online, 3 (1), pp. 3-13.

Pereira, Maria do Mar (2017), Power, Knowledge and Feminist Scholarship: an Ethnography of Academia, London, Routledge.

Pereira, Maria do Mar (2018), "Em Defesa da Pesquisa Lenta numa Época de Ciência Acelerada", Revista Crítica de Ciências Sociais, 116, pp. 197-202.

Pereira, Maria do Mar (2019), "«You Can Feel the Exhaustion in the Air Around Youn: The Mood of Contemporary Universities and its Impact on Feminist Scholarship", ex aequo, 39, pp. 171-186.

Santos Pereira, Tiago (2020), "Publicação Científica" em J. Reis (org.), Palavras para Além da Pandemia: Cem Lados de uma Crise, Coimbra, Centro de Estudos Sociais, p. 86.

Scharff, Christina (2016), "The Psychic Life of Neoliberalism: Mapping the Contours of Entrepreneurial Subjectivity", Theory, Culture \& Society, 33 (6), pp. 107-122. 
Shelley-Egan, Clare (2020), "Testing the Obligations of Presence in Academia in the COVID-19 Era", Sustainability, 12 (16), artigo 6350.

Shore, Cris; e Susan Wright (2000), "Coercive Accountability: the Rise of Audit Culture in Higher Education" em M. Strathern (org.), Audit Cultures: Anthropological Studies in Accountability, Ethics and the Academy, London, Routledge, pp. 57-89.

Sousa, Sofia Branco (2020), "Conhecimento, Ciência e Mercado" em J. Reis (org.), Palavras para Além da Pandemia: Cem Lados de uma Crise, Coimbra, Centro de Estudos Sociais, p. 33.

Sparkes, Andrew C. (2007), "Embodiment, Academics, and the Audit Culture: a Story Seeking Consideration", Qualitative Research, 7 (4), pp. 521-550.

Stadnyk, Tricia; e Kerry Black (2020), "Lost Ground: Female Academics Face an Uphill Battle in Postpandemic World", Hydrological Processes, 34 (15), pp. 3400-3402.

Utoft, Ea Høg (2020), "'All the Single Ladies' as the Ideal Academic During Times of COVID-19?", Gender, Work \& Organization, 27 (5), pp. 778-787.

Vale de Almeida, Miguel (2020), Não Compliquem, 13/09/2020.

Weeks, Kathi (2011), The Problem With Work: Feminism, Marxism, Antiwork Politics, and Postwork Imaginaries, Durham, Duke University Press.

Wright, Katharine A. M.; et al. (2020), "Equalities in Freefall? Ontological Insecurity and the Long-Term Impact of COVID-19 in the Academy", Gender, Work \& Organization, online before print. 
Entrevista realizada a Maria do Mar Pereira no âmbito da rubrica "Um olhar sociológico sobre a crise Covid-19", publicada a 30 de maio de 2020.

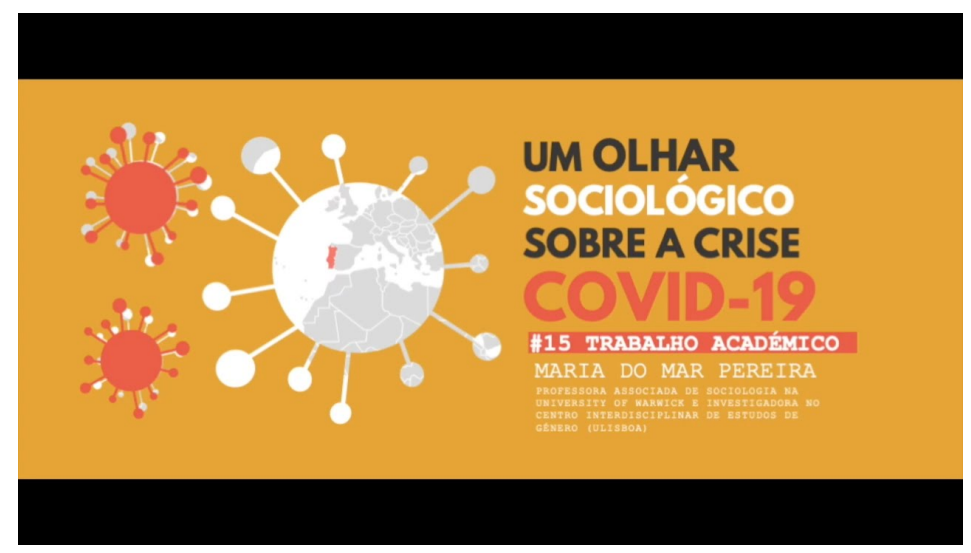




\section{CAPÍTULO 15}

\section{HABITAR O TEMPO: UMA POLÍTICA DE RECONSTRUÇÃO DO SIMBÓLICO}

\section{Renato Miguel do Carmo}

Professor associado no Iscte - Instituto Universitário de Lisboa, Diretor do Observatório das Desigualdades, Investigador do CIES-Iscte

Confinados em casa, mas desabitados

Durante o período do confinamento escrevi conjuntamente com o filósofo André Barata uma série de dez artigos intitulada Soberanos do Tempo, publicados semanalmente no Jornal Económico'. Ao longo dos escritos fomos detetando relações e interceções entre os vários temas abordados e o modo como as diferentes temporalidades se manifestaram no contexto da pandemia de Covid-19, aprofundando, em muitos casos, tendências que já vinham de trás.

Embora a série não se tenha focado especificamente sobre o tema das desigualdades, é possível evidenciar, através da leitura transversal dos diversos artigos, que a interseccionalidade gerada entre as diferentes desigualdades e injustiças sociais tornam-se ainda mais vincadas e irredutíveis quando cruzadas com as temporalidades vigentes, tanto as dominantes que se uniformizam crescentemente e atingem quase todos, como as que corporizam opressões, vulnerabilidades e precariedades. Na verdade, as temporalidades interseccionam-se com as múltiplas desigualdades (de rendimento, de género, de etnia e raça, etc.), com os distintos modos de vida (incluindo os da vivência da morte), com os ritmos de aceleração e os momentos de paragem, com as dimensões do humano e a dificuldade de

1 Este artigo baseia-se e aprofunda o conteúdo do último texto da série, intitulado Soberanos do Tempo (10). 
superação da biologia, com a dura realidade dos processos distópicos ou a alternativa das utopias realistas.

O tempo social está embutido nos poros da sociedade, das suas superfícies mais ásperas e irregulares aos seus recantos mais escondidos e impercetíveis (Carmo e d'Avelar, 2020). Daí ser um conceito difícil de abordar e que requer um constante debate entre diferentes disciplinas e saberes. A referida série de artigos teve a preocupação de recorrer a diversos autores e referências das ciências sociais e da filosofia. Por outro lado, tentámos, na redação de cada um dos tópicos, descodificar e desvelar algumas invisibilidades nem sempre discutidas no espaço púbico, nos debates políticos ou nos fóruns científicos. De facto, apesar da sua transversalidade enquanto assunto de discussão, o tempo social é recorrentemente remetido para uma certa clandestinidade, um tema que não merece grande aprofundamento. Contudo, no que diz respeito ao impacto da crise pandémica, parece não haver grande dúvida de que esta intensificou a periferização das temporalidades destoantes do modelo produtivista, ou seja, aquelas que não se encaixam na engrenagem da indústria que transforma quase tudo em mercadoria.

Num dos seus mais recentes livros, o filósofo Byung-Chul Han (2019) refere que o capitalismo atual intensificou a coação para produzir, estendendo-a a múltiplas esferas do económico e do social. Nas suas palavras, "a actual coacção para produzir priva as coisas da sua durabilidade" (Han, 2019: 13). A referida privação alicerça-se, entre outros fatores, na destituição dos rituais que marcavam a vida quotidiana e que, segundo o autor, são substituídos por um "fluxo inconsistente" em que os gestos e ações tendem a ajustar-se e a formatar-se aos ritmos da produtividade. Outro filósofo, Bernard Stiegler (2018), fala-nos da industrialização de quase todas as coisas e da consequente uniformização e acomodação das diversas temporalidades do social aos ciclos da produção económica. Em parte, esta estandardização significa a sobreposição de um tempo abstrato e contínuo às restantes formas de temporalidade, confinando-as, por sua vez, para as margens dos sistemas e das arenas de comunicação e 
debate. André Barata (2018) refere-se a esta continuidade como um tempo sem fissuras, que não permite desvios, paragens ou meras pausas que não estejam previstas no funcionamento da engrenagem.

Outro aspeto salientado por Han (2019), que decorre da atual coação para produzir, revela-se no esvaziamento do simbólico nas relações sociais e nas formas de interpretação do mundo que são acionadas pelos indivíduos. Como refere Ken Plummer, vários sociólogos enquadrados na perspetiva teórica do interacionismo simbólico, como Herbert Mead ou Erving Goffman, demonstraram que "os mundos distintamente humanos não são só mundos materiais e objetivos, mas também fortemente simbólicos" (Plummer, 1996: 225). Contudo, o que se verifica na atual fase do capitalismo globalizado e de cariz neoliberal é, ao invés, uma forte pressão para uma visão ou um pensamento único, invariável e indiscutível que aponta para uma única direção, como se não existisse alternativa ou outros significados possíveis (Bourdieu, 1998).

Os rituais são elementos incontornáveis de estabilização e de organização da vida social. Representam um pressuposto para tornar o mundo num lugar plausível e que faça sentido. Ou, segundo o filósofo de origem coreana, "tornam o mundo um lugar fiável" (Han, 2019: 12). O tempo não pode existir nos indivíduos e persistir nas sociedades contemporâneas apenas como passagem e fluxo. Uma mera sequência numérica que impõe ritmos externos, aos quais não conseguimos escapar. Em contrapartida, o tempo deve poder ser morada habitável, onde se está mais do que de passagem. É essa possibilidade de habitar que atribui durabilidade ao tempo, na qual os rituais se concretizam em ciclos recursivos que orientam a ação e as relações sociais. São eles que "transformam o estar-no-mundo num estar em casa" (Han, 2019: 12). Os rituais são estabilizadores da vida quotidiana e é a partir deles que se constituem e se corporizam muitas das ligações sociais e das formas de solidariedade no seio da comunidade. Os rituais são marcadores do dia-a-dia (a pausa para café que ocorre por voltas das $11 \mathrm{~h}$ e reúne os colegas de trabalho na cafetaria, o almoço aos domingos que junta a 
família, as saídas às sextas-feiras à noite com os amigos) e nesse sentido são antecipadores de encontros que se realizam recorrentemente.

A destituição dos rituais significa, entre outros aspetos, uma destabilização da vida quotidiana, afetando deste modo a noção de durabilidade no sentido em que quase tudo se apresenta como incerto, não se depreendendo antecipadamente se determinado encontro ou situação vai ou não realizar-se. Dificilmente este terá lugar se interferir no curso linear e contínuo da engrenagem produtivista. O tempo sem durabilidade é, assim, mero fluxo sem possibilidade de ser habitável, torna-se em tempo destituído de lugar.

A experiência do confinamento e do distanciamento físico (que em parte ainda se mantém) devido ao impacto da pandemia de Covid-19 aprofundou ainda mais esta perceção de perda de durabilidade do tempo vivido. Na verdade, a pandemia precarizou tanto a experiência de habitação do tempo como do próprio espaço, no sentido em que estar em casa deixou necessariamente de significar estar-no-mundo. Viveu-se durante a quarentena uma compressão do espaço-tempo que rompeu com a maior parte das ritualidades que caracterizavam até aí o dia-a-dia. De um momento para o outro, a vida de trabalho, a vida escolar (entre outras), confluíram para o espaço apertado da vida doméstica. A casa perdeu o seu significado social e simbólico, assim como a sua funcionalidade habitual, e incorporou outras exigências e demandas que não se coadunam com a vivência de um ambiente caseiro.

Por sua vez, muitos dos rituais foram interrompidos, na medida em que assentavam na realização de encontros e de relações que deixaram de poder acontecer. Ironicamente, o enclausuramento nas nossas casas, para aqueles que tiveram condições económicas e de habitabilidade de o fazer, representou para muitos uma guarida e uma proteção acrescida face ao surto viral, mas significou, simultaneamente, uma precarização da habitação do espaço-tempo com consequências profundas na desestruturação da vida quotidiana e da redução e compressão dos rituais à invariabilidade do tempo da produção (por exemplo, através 
do exercício quase permanente do teletrabalho, intermediado pelo apoio à telescola e às tarefas domésticas).

Num estudo realizado por uma equipa do CoLABOR - Laboratório Colaborativo para o Trabalho, Emprego e Proteção Social, que assentou na análise de um conjunto amplo de testemunhos recolhidos num inquérito por questionário durante o período do confinamento2, identificaram-se três tipos de temporalidade a partir da experiência abrupta do teletrabalho. O primeiro, designado de tempo contínuo como desgastante, caraCteriza-se precisamente pela vivência de uma temporalidade "em que basicamente se está sempre a trabalhar ou não se cessa de trabalhar por períodos que se prolongam, em alguns casos, até ao final da noite". Nestes casos, os testemunhos revelam que têm muito pouco controlo sobre a organização do seu tempo e que os marcadores quotidianos habituais que constituem as rotinas diárias se esvanecem, "não havendo fronteiras estabelecidas entre o tempo de trabalho e, por exemplo, as pausas para almoço ou jantar" (Silva et al., 2020: 22).

Um segundo tipo expressa também essa sensação de tempo contínuo, mas ao contrário do anterior, enfatiza que este lhe foi benéfico para aumentar o seu nível de produtividade, "perante o qual se valoriza o facto de se poder trabalhar sem interrupções ou grandes distrações" (Silva et al., 2020: 22). Para estas pessoas, a experiência do teletrabalho permite ser mais produtivo porque não se é sujeito a interferências e a quebras que resultavam, designadamente, da necessidade das deslocações ao local de trabalho ou das reuniões presenciais entre colegas que, por vezes, se prologavam por várias horas. Trata-se de um tipo de temporalidade que sublinha o

\footnotetext{
2 A aplicação do inquérito online "decorreu entre os dias 25 e 29 de março de 2020 (1. ${ }^{\text {a vaga) }}$ e entre os dias 24 de abril e 4 de maio (2. ${ }^{a}$ vaga). $O$ inquérito foi coordenado por uma equipa do Instituto de Ciências Sociais da Universidade de Lisboa (ICS-ULisboa) e do ISCTE Instituto Universitário de Lisboa (ISCTE-IUL). A amostra obtida é uma amostra 'bola de neve' ou 'guiada pelo respondente': o inquérito foi partilhado através das redes sociais Facebook e Twitter e de correio eletrónico pelos coordenadores do estudo e pelas instituições a que pertencem junto de uma amostra não-aleatória de indivíduos". (Silva et al., 2020: 39)
} 
ajustamento quase completo à coação para produzir. $\bigcirc$ tempo industrializado toma assim conta do quotidiano doméstico e torna-se ainda mais predominante e inquebrável.

O terceiro denomina-se de tempo fragmentado como improdutivo e desgastante, e afetou principalmente os agregados familiares com dependentes (crianças e/ou idosos) a cargo: "nestes casos, a perceção realçada nas respostas é de um tempo fragmentado e constantemente interrompido por um sem número de atividades e de solicitações que, por vezes, acontecem em simultâneo e são concentradas numa área reduzida que se circunscreve a poucas divisões da habitação. A produtividade diminui drasticamente e vive-se num stress permanente que afeta também a qualidade das relações sociais ocorridas em proximidade. A conciliação e a simultaneidade entre as atividades profissionais e o cuidar dos outros (que podem incluir familiares mais idosos) é vivida com grande dificuldade e com um peso acrescido que tende a sobrecarregar mais as mulheres" (Silva et al., 2020: 23).

Tendo como referência estas três modalidades, verifica-se que as duas primeiras enfatizam uma propensão de adaptação à coação para produzir, apesar de a primeira expressar uma insatisfação relativamente à perda de controlo sobre o tempo e ao facto de o trabalho se estender por horas inapropriadas e sem interrupções. Em contrapartida, a última revela uma incapacidade de adaptação, mas que decorre fundamentalmente das condições físicas, económicas e emocionais do agregado familiar, que impossibilita o ajustamento devido à pressão para a produtividade.

A apresentação sintética destes três tipos surge como mera ilustração de como o confinamento precarizou ainda mais a experiência de habitação. Embora relativamente protegidas em casa, as pessoas que transitaram abruptamente para o teletrabalho foram quase despojadas da possibilidade de habitar devidamente o tempo e o espaço. Na verdade, apesar de situadas no contexto do lar, muitas pessoas sentiram-se sitiadas dos direitos mais básicos, como o da soberania sobre o seu próprio tempo. Encontravam-se confinadas em casa, mas, simultaneamente, sitiadas da possibilidade de habitar o 
espaço e o tempo. Ou seja, desabitaram os seus mundos habituais. Deste modo, a experiência da quarentena significou a experiência de estar-em-casa, mas sem estar-no-mundo. Suspendeu-se assim a ligação ao mundo da vida (lebenswelt), segundo a conceção de Jürgen Habermas, isto é, aos significados e valores partilhados, aos processos comunicativos e aos aspetos mais rotinizados da vida social.

\section{Para desconfinar a política do tempo}

Só a partir das temporalidades destoantes se poderão gerar alguns curto-circuitos na fabricação da engrenagem do tempo abstrato e contínuo, que parece não ter fim. Assim, para que o tempo tenha futuro e não seja mais do que um constante presente agarrado ao simples mecanismo da passagem, é necessário que se dê a interrupção do fluxo.

Interromper a passagem mecanizada e meramente cronológica pode representar, por exemplo, reter uma membrana do tempo a que retornamos por vontade e desejo próprios, sem que uma força exterior nos impele a ter obrigatoriamente de seguir em frente e largá-la irremediavelmente para trás. Essa membrana pode deter um significado particular que apenas nós reconhecemos, como pode gerar novos esquemas simbólicos passíveis de serem partilhados em comunidades e coletividades. Interromper significa assim uma delonga que resiste à voragem da aceleração, ou um desvio à sequência antecipadamente traçada, ou uma fissura que altera irremediavelmente o sentido prévio do fluir. Resgatar o tempo do seu fluxo inconsistente é um desafio ambicioso, mas necessário, que se tornou ainda mais urgente com o deflagrar da pandemia e dos seus inúmeros e assimétricos impactos na vida comum. Resgatar o tempo pressupõe tomá-lo e moldá-lo com as nossas mãos, dotá-lo de autonomia e de vontade própria, recusando as inevitabilidades da indústria e do mercado. É transformá-lo em política para todos.

Não cabe aqui esgotarmos os eixos que deveriam nortear a política do tempo, contudo enuncia-se quatro princípios gerais que poderiam 
ser incrustados na conceção e ação das políticas públicas em várias escalas e domínios de intervenção. $\bigcirc$ primeiro tem a ver com a capacidade de projetar e de construir nas várias áreas da existência um plano. Esta crise destapou um sem número de fragilidades sociais e económicas, incluindo a maior ou menor capacidade dos Estados e dos governos fazerem face a crises profundas e inesperadas. Apesar de se ter assistido a respostas muito diferenciadas, umas mais capazes que outras, não resta grande dúvida sobre a necessidade de os governos centrais e locais incorporarem o plano como um instrumento imprescindível no seu roteiro de atuação. Não se trata de incutir a planificação das atividades por via de uma nova cultura burocrática, mas de incentivar a construção de planos que tracem horizontes previsíveis de futuro, constituídos por metas e objetivos a alcançar a partir de escolhas tomadas no presente. Escolhas essas alicerçadas no conhecimento científico e em processos democráticos de deliberação. E assim devolver, com significado, a dimensão de projeto ao tempo vivido.

O segundo eixo designa-se de proteção. A possibilidade de projetarmos autonomamente futuros próprios depende em grande medida da situação social e económica que se leva no presente. Se vivemos em presentes precários marcados pela desigualdade, pela constante incerteza e completa dependência aos fatores e às intempéries dos mercados, jamais teremos aptidão de criar projetos duráveis capazes de construir futuro. A manutenção da desproteção no presente é a melhor garantia para nos acomodarmos ao mero correr do fluxo, que nos transporta para um tempo sem rumo definido, inabitável. Proteger as pessoas nas várias esferas (do mundo laboral à sociedade do cuidar) é uma condição essencial para que o tempo tenha futuro.

$O$ terceiro eixo consubstancia-se em permitir a singularidade do tempo. Apesar da importância de criar condições para a implementação de planos, estes não podem esgotar todas as hipóteses de ação. Parte do nosso futuro deve ser imprevisível e aberto a possibilidades inesperadas que surjam, especialmente de forças criativas e emancipatórias. Neste sentido, é fundamental dar espaço e 
tempo ao tempo, para que este aconteça sem imposições prévias e direções pré-estabelecidas. Uma política do tempo não deverá recuar ao primeiro obstáculo que interfira no plano delineado na base de intenções meritórias, democraticamente escrutinadas, mas deve, concomitantemente, permitir a abertura a singularidades não antecipáveis e potenciadoras de improbabilidades virtuosas.

Precisamos induzir previsibilidade no tempo, para que a incerteza não se torne ainda mais dominante nas nossas vidas, contudo é necessário dar alguma margem a desarrumações geradas por sentidos inesperados e únicos, que a prazo possam ter retorno na melhoria geral das condições de vida e do bem comum. Só assim se resistirá e se combaterá as várias ditaduras do tempo.

Finalmente, é fundamental reconstruir o simbólico no nosso mundo, de maneira a entrelaçar o tempo e o espaço na (re)atualização de velhos e novos rituais vividos em comunhão e solidariedade. Reconstruir o sentido e a vivência do ritual, partilhado e em proximidade com os outros, representa um pressuposto básico para poder habitar o tempo no espaço comum. Ou, dito de outro modo, não é possível implementar uma política que aprofunde os eixos anteriores sem empreender previamente essa reconstrução do simbólico que garanta o (re)ligamento com o mundo (Barata, 2020).

Referências bibliográficas

Barata, André (2018), E se Parássemos de Sobreviver? Pequeno Livro para Pensar e Agir Contra a Ditadura do Tempo, Lisboa, Documenta.

Barata, André (2020), O Desligamento do Mundo e a Questão do Humano, Lisboa, Documenta.

Bourdieu, Pierre (1998), Contrafogos, Oeiras, Celta Editora.

Carmo, Renato Miguel do; e Maria Madalena d'Avelar (2020), A Miséria do Tempo: Vidas Suspensas pelo Desemprego, Lisboa, Tinta-da-China.

Han, Byung-Chul (2019), O Desaparecimento dos Rituais, Lisboa, Relógio D'Água. 
Plummer, Ken (1996), "O interaccionismo simbólico no século XX: a emergência da teoria", em Bryan S. Turner (ed.), Teoria social, Lisboa, Difel, pp. 225-245.

Silva, Pedro Adão; Renato Miguel do Carmo; Frederico Cantante; Catarina Cruz; Pedro Estêvão; Luís Manso; Tiago Santos Pereira; e Filipe Lamelas (2020), "Trabalho e desigualdades no Grande Confinamento (II)", Estudos CoLABOR, N. ${ }^{\circ} 3 /$ junho de 2020, CoLABOR.

Stiegler, Bernard (2018), Da Miséria Simbólica - I. A Era Hiperindustrial, Lisboa, Orfeu Negro. 
Entrevista realizada a Renato Miguel do Carmo no âmbito da rubrica "Um olhar sociológico sobre a crise Covid-19", publicada a 2 de junho de 2020.

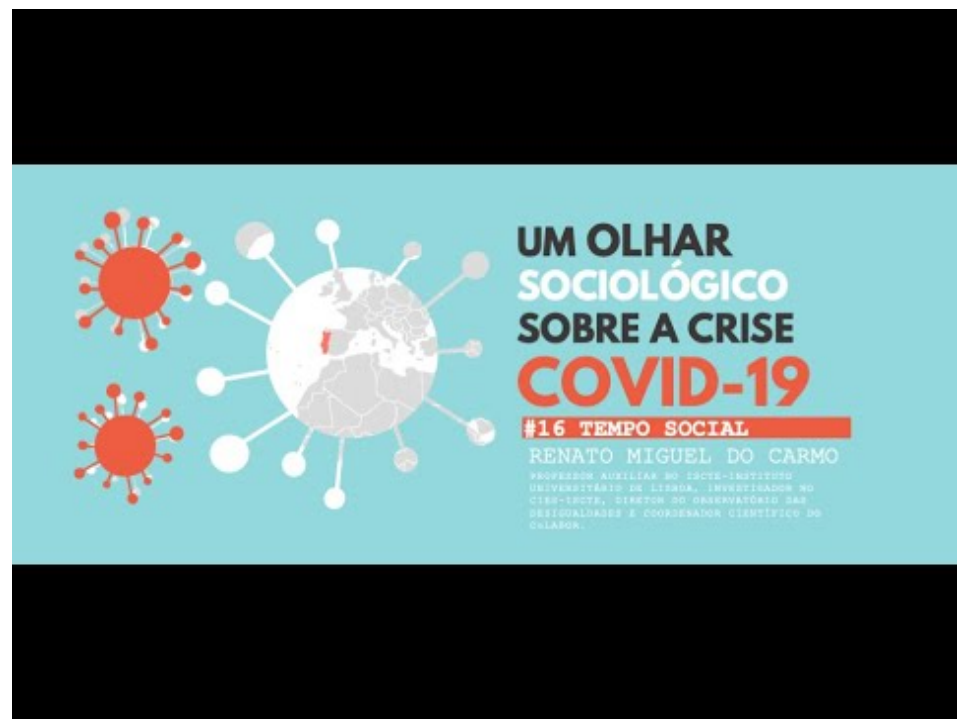




\section{CAPÍTULO 16}

BALANÇO E PERSPETIVAS DE FUTURO: O IMPACTO DA COVID-19 E A (RE)PRODUÇÃO DAS DESIGUALDADES SOCIAIS

\section{Inês Tavares e Ana Filipa Cândido}

Investigadoras do Observatório das Desigualdades, Iscte - Instituto Universitário de Lisboa, CIES-Iscte

O impacto da Covid-19 nas desigualdades sociais é ainda um tema bastante recente e qualquer análise poderá ser prematura e permeável ao confronto com a realidade futura. No entanto, existem já algumas evidências relevantes a sublinhar, nomeadamente que o impacto do vírus não é igual para todas as pessoas: existem diferenças sistémicas de saúde entre pessoas que estão em posições desiguais na hierarquia social e evidências que a saúde piora à medida que se desce na hierarquia social (Cabral et al., 2002; Scambler, 2012).

As pessoas mais afetadas por esta crise são também as mais vulneráveis do ponto de vista das desigualdades sociais, as que têm menos capitais sociais, económicos, culturais e simbólicos (no sentido exposto nos estudos acerca da reprodução social de Bourdieu, 2020 [1979]), na medida em que, por um lado, são as mais afetadas pela própria doença e, por outro lado, são as que sofrem mais consequências económicas e sociais negativas no presente e, previsivelmente, no futuro. Neste quadro, está-se perante um plano de reprodução das desigualdades sociais, particularmente centrado nos efeitos das desigualdades sociais preexistentes na resposta às consequências derivadas desta crise: os mais vulneráveis socialmente têm menos recursos para lidar com os efeitos originados pela Covid-19, estando precocemente numa posição de desvantagem social.

A pandemia é responsável pelo aumento da pobreza, podendo levar cerca de "(...) 71 milhões de pessoas de volta à pobreza extrema em 2020, no que seria o primeiro aumento da pobreza global desde 
1998." (United Nations, 2020: 3). ${ }^{1}$ Além desta possibilidade retomar a ideia da reprodução das desigualdades sociais numa lógica da sua intensificação, causada por esta crise, constitui-se também como um fator de produção das desigualdades sociais, colocando alguns atores sociais em novas posições e situações sociais.

A investigação e a imaginação sociológicas fornecem ferramentas importantes e um contributo relevante para pensar o mundo atual, no contexto da Covid-19. Se a biologia e a medicina têm um contributo na procura da solução para o surto do vírus, as ciências sociais, e particularmente a sociologia, têm o papel de aprofundar o conhecimento acerca do modo como o vírus afeta as sociedades em que vivemos, desvendando as desigualdades sociais que predominam, surgem e se acentuam com esta pandemia, bem como as consequências e os desafios que se colocam. Um melhor discernimento sobre a análise das desigualdades sociais é essencial para enfrentá-las de maneira mais consciente no momento presente e no desenho de políticas públicas futuras. Assim, a produção científica sistemática tem revelado uma importância elevada na elaboração de respostas adequadas.

Neste balanço e perspetivas de futuro reflete-se sobre três desafios estruturais para o futuro: (i) a reprodução e aumento das desigualdades sociais; (ii) a expansão do teletrabalho; e (iii) a questão da tecnovigilância.

Reprodução e aumento das desigualdades sociais

É importante compreender aprofundadamente e com rigor o modo como esta pandemia, a exemplo de outras pandemias e crises, potenciou e agravou novas e velhas desigualdades sociais. As desigualdades sociais são múltiplas, como este livro espelha, nomeadamente na saúde, cultura, educação, família e género, ensino superior, trabalho, habitação, rendimento e Segurança Social, pobreza,

\footnotetext{
1 Tradução feita pelas autoras.
} 
desigualdades sociolinguísticas e étnico-raciais, de género, ambiente, rendimento, trabalho académico, tempo social e as desigualdades sociais como um todo.

Como evidenciado previamente, o vírus não afeta de igual forma os indivíduos, existindo diferenças na vulnerabilidade à pandemia. Apesar de todas as pessoas correrem o risco de contrair a Covid-19, a verdade é que em termos de diagnóstico e resultado alguns indivíduos apresentam-se mais expostos à doença. Estas diferenças, apesar de teoricamente biológicas, são estruturalmente sociais, podendo ser interpretadas na perspetiva das desigualdades vitais, dado que existem países e regiões mais sujeitos à infeção e a estados mais gravosos da doença do que outros (Therborn, 2013: 49-53). Entre países existem desigualdades vitais perante a vida, a morte e a saúde, devendo-se em parte aos recursos de saúde insuficientes para prevenir e enfrentar determinadas doenças (Costa, 2012), pela falta de capacidade de teste, rastreamento e tratamento, além de outras condições desiguais que afetam as condições vitais diferenciadas entre países. ${ }^{2}$

A vertente social do vírus permite explicar melhor a maneira como este afeta os indivíduos, como atua e se espalha. As desigualdades sociais pré-existentes, vitais e de recursos, interferem: (i) na exposição ao vírus, afetando mais os grupos que têm maior incapacidade de se proteger; (ii) na forma como lidam com as consequências sociais imediatas da pandemia, especialmente $o$ isolamento social $e$ as medidas políticas associadas; (iii) e nas consequências desta pandemia no exacerbamento ou surgimento de novas desigualdades sociais.

\footnotetext{
2 Segundo Milanovic (2016: 128), a maioria das desigualdades globais dependem do local onde as pessoas nascem - location based inequality, i.e os indivíduos estão expostos a uma variedade de desigualdades sociais e económicas conforme o país em que nascem, sendo que uns usufruem de citizenship premium e outros de citizenship penalty (idem, ibidem: 132). Ainda que Milanovic se foque estritamente nas desigualdades de rendimento, esta ideia é facilmente aplicável às desigualdades sociais vitais, na medida em que alguns também usufruem de um citizenship premium ao nível vital por terem nascido num local com melhores condições de saúde e onde as taxas de mortalidade são menores, entre outros.
} 
No que diz respeito à exposição à doença, algumas das condições sociais que revelam uma maior vulnerabilidade são: (i) os locais com maior densidade populacional, pela maior sobrelotação das habitações e dependência do uso de transportes públicos lotados, que tornam mais difícil o distanciamento entre as pessoas, aumentando assim o risco de transmissão do vírus, logo mais incidência de casos acumulados; (ii) áreas industrializadas. A este respeito, Caldas, Lamelas e Estevão (2020) demonstraram que, em abril de 2020, as áreas com uma maior proporção de trabalhadores ao serviço das empresas da indústria são também os concelhos com um maior número de casos, o que se deve principalmente ao facto do sector da indústria transformadora, ao contrário de outros setores, se ter mantido em laboração ao longo deste período.

$\mathrm{Na}$ forma como lidam com as consequências sociais e económicas da pandemia, destacam-se alguns grupos pela desvantagem em que se encontram: os trabalhadores precários com contratos temporários ou sem contratos, por exemplo, estão muito mais expostos ao desemprego do que trabalhadores com contratos estáveis. Cruzando as duas desigualdades referidas acima de forma mais severa - isto é, tanto na exposição à doença como na posição de desvantagem perante as adversidades da pandemia - encontra-se a população com vínculos de trabalho precários que, de forma a não perder os seus rendimentos, tem de continuar a trabalhar presencialmente. Esta exposição é ainda mais agravada se se tiver em conta que esta população detém escassos recursos económicos e, por exemplo, as suas deslocações são feitas através de transportes públicos, espaços onde a contaminação é mais propícia, comparando com deslocações em carro individual. É de assinalar ainda que uma parte significativa destas profissões são bastante feminizadas, como os trabalhos de limpeza, de cuidados e assistência social. Parte destes trabalhadores, os mais vulneráveis, são imigrantes de grupos étnicos minoritários, os quais já se encontram em desvantagem pelo facto de a informação divulgada sobre o vírus, os sintomas, medidas de prevenção, entre outros, não corresponder à real diversidade linguística das populações. Além de um menor nível de 
literacia, logo potencialmente com mais dificuldades em adotar providências adequadas para se protegerem, previsivelmente também estão em situações de trabalho mais precárias.

Os indivíduos com trabalhos que não podem ser realizados à distância ou que estão em setores que suspenderam o funcionamento são tendencialmente trabalhadores de baixas remunerações, vínculos precários e baixas qualificações, o que revela o quadro mais amplo de intersecção de desigualdades sociais e coloca indivíduos em posições de múltiplas desvantagens sociais. Nestes casos, as desigualdades acumuladas, e acrescidas com a crise pandémica, coloca-os numa posição mais vulnerável à exposição ao vírus e na resposta à crise, por exemplo, casos de desemprego e diminuição acentuada dos rendimentos.

As desiguais condições de vida correspondem a desiguais riscos de infeção, sendo que condições de vida adversas estão, geralmente, associadas à prevalência de doenças infetocontagiosas, e a desiguais riscos socio-económicos, na medida em que as consequências da precariedade e do desemprego gerados pela pandemia tendem a afetar mais a população que já se encontrava nestas condições.

Considerando que as desigualdades sociais não só ficaram mais evidentes com esta crise pandémica, ganhando visibilidade social e sociológica, como se agravaram e tenderão a agravar no futuro e no pós-crise pandémica, acompanhar as tendências da evolução das desigualdades sociais a curto e a médio prazo apresenta-se como um desafio incontornável para a sociologia.

\section{Expansão do teletrabalho}

O recurso ao teletrabalho durante a presente crise poderá abrir campo à sua expansão no futuro e fez desde já sobressair algumas tendências: a perca do espaço e do ambiente de trabalho, mais custos para os trabalhadores - nomeadamente em material ou nos custos de eletricidade e internet -, menos organização coletiva ou, por exemplo, a extensão do tempo de trabalho (Silva et al., 2020a e Silva et al., 2020b). 
O teletrabalho é também uma modalidade que torna patente a dinâmica de desigualdades sociais, como se aprofundará nesta secção.

É importante referir que a população que aufere rendimentos mais baixos está não só mais exposta ao vírus como encontra maiores dificuldades quando colocada em situação de teletrabalho. Por um lado, o rendimento é condição importante para o acesso a melhores condições de habitabilidade, com adequada rede de abastecimento de água e energia, com uma maior eficiência energética, entre outros fatores que são fundamentais tanto para a higienização pessoal, importante na diminuição da exposição ao vírus, como para o maior e melhor acesso à internet e a um ambiente de trabalho confortável e calmo, propícios a um bom desempenho profissional. De acordo com os dados do Instituto da Habitação e Reabilitação Urbana (IHRU, 2018), em 2018 eram mais de 26 mil as famílias sem condições adequadas e que necessitavam de ser realojadas, logo, sem condições adequadas para fazer face a este período.

Por outro lado, o rendimento também é condição para um melhor apetrechamento de material de trabalho nas habitações. Na transição para o teletrabalho, questões como o acesso a um computador em casa ou uma cadeira confortável tornaram-se ainda mais relevantes. De facto, e sobretudo em agregados familiares que não possuem um computador por pessoa ou que estão sobrelotados, o teletrabalho afigura-se de maior dificuldade. Exemplo notório foi a dificuldade da adaptação à telescola em agregados familiares com dependentes a cargo: com os computadores disponíveis a serem necessários para teletrabalho ou para a telescola de outros elementos do agregado familiar. Por vezes, os alunos por vezes tiveram de trabalhar e assistir a aulas através do telemóvel ou enquanto desempenhavam outras funções domésticas, colocando-se num lugar de desvantagem perante outros alunos em que esta situação não ocorreu.

Ainda neste quadro, é importante relevar os desiguais (ou diferentes) níveis de literacia digital que potenciam a desigualdade entre as populações que se veem obrigadas a utilizá-las para a 
manutenção do seu trabalho, para apoiar os filhos na telescola, para acesso a informação ou para a comunicação com outras pessoas.

Além das desiguais condições materiais de acesso dos trabalhadores e estudantes, é relevante refletir acerca do que se perde no trabalho e na escola virtual, sendo o principal ponto a falta de interação presencial. Sem a possibilidade de um contacto direto entre trabalhadores, ou entre alunos e professores, a interação tende a ser remetida para um campo mais artificial, em que o contacto e a discussão por vezes se esvaziam, não se criando os momentos e os laços necessários para o desenvolvimento de um importante ambiente coletivo de partilha entre pares.

Considerando a sobrecarga que o teletrabalho acarreta, o trabalho doméstico é um elemento incontornável da reprodução das desigualdades. Com uma maior utilização da habitação e uma necessidade de mais tempo despendido em cuidados com as crianças e idosos, o trabalho doméstico assume ainda maior relevância no quotidiano. Sabendo que são geralmente as mulheres que acarretam estes trabalhos, além de aumentar a sua dupla jornada de trabalho, na medida em que é necessário mais tempo para os cuidados, o acompanhamento dos dependentes que agora se encontram a maior parte do tempo em casa, uma maior gestão do espaço doméstico e mais tempo despendido em limpezas e confeção de alimentação, cria uma óbvia desigualdade entre homens e mulheres que, por sua vez, se agrava com a execução em simultâneo do teletrabalho. Esta desigualdade já era assinalável no trabalho presencial, devido à maior sobrecarga resultante do duplo trabalho acumulado, mas fica ainda mais evidente com a transição para o teletrabalho durante o confinamento.

Assim, é importante refletir que efeitos terá o teletrabalho na relação entre a vida profissional e a vida pessoal e familiar. Algumas das vantagens apontadas ao teletrabalho prendem-se com a poupança de tempo e custos na mobilidade espacial e urbana (Silva et al., 2020b) e a flexibilização dos horários de trabalho, porém até que ponto é que isto de facto acontecerá ou se, pelo contrário, a vida profissional vai 
inevitavelmente sobrepor-se à vida pessoal e familiar? Até que ponto vai aumentar, de facto, o tempo de trabalho? Que consequências terá o aumento da impessoalidade e a diminuição das relações de sociabilidade nos locais de trabalho? De que modo é que o teletrabalho favorece uma maior rotinização do trabalho e, nalguns casos, poderá ser conducente a processos de desprofissionalização?

\section{Tecnovigilância}

Muitas das mudanças referidas já existiam e foram aceleradas pela pandemia, como é o caso do teletrabalho, mas também da tecnovigilância, podendo a nova dimensão que assume criar efeitos novos na sociedade. No caso da tecnovigilância é de notar o risco de normalização e até de legitimação da vigilância digital em nome de um suposto "bem comum".

O "bem comum" é, historicamente, uma premissa habitual quando se trata de legitimar uma maior vigilância das populações. Assim, se neste caso concreto a noção de "bem comum" consubstancia-se no controlo da infeção de um vírus, no futuro esta pode ser utilizada com qualquer outro pretexto para os mesmos fins. A tecnovigilância materializou-se, por exemplo, em drones que circundavam cidades de forma a "manter a ordem" e controlar se as pessoas estavam na rua ou em aplicações digitais para controlar a localização dos cidadãos ou se estes se tinham cruzado com pessoas infetadas. Mesmo não sendo de utilização obrigatória, estes e outros dispositivos podem pôr em causa a liberdade individual e a própria ideia de democracia. Portanto, de que modo as questões da cidadania e da vivência e qualidade da democracia vão ser afetadas pelo aumento da tecnovigilância?

Também a pretexto da propagação do vírus se suspenderam direitos e liberdades individuais, sendo a mais imediata e transversal à maioria dos países a de circulação e ajuntamento de pessoas. Neste ponto, a tecnovigilância assumiu um papel relevante, como mecanismo de controlo e policiamento da localização dos cidadãos. Sabendo que atualmente já existem ferramentas para um controlo minucioso das 
populações através de geolocalização ou de utilização de dados bancários, importa pensar as consequências passíveis da sua utilização para policiamento das populações num momento em que existam condições subjetivas para a sua utilização, assumida por parte das entidades tanto políticas como de policiamento. E, no caso de se estarem a criar essas mesmas condições subjetivas, ao fomentar-se a ideia de medo do vírus e da importância do controlo da população, que papel deverá ter um Estado democrático na sua (não) utilização?

Esta vigilância aumentou também nos espaços privados e na intimidade das populações, sendo impulsionada uma autovigilância. Como tal, mais uma vez, uma questão relacionada com a saúde constitui um pretexto para, nas palavras de Foucault (2018 [1975]): vigiar e punir.

\section{Notas finais}

A forma como os diferentes governos e instituições, incluindo a Organização Mundial de Saúde (OMS), foram gerindo esta crise convoca-nos para a ideia de sociedade de risco (Beck, 2015 [1986]), imperando a gestão da racionalização do risco, seja ele económico, social, de saúde, climático, entre outros. Num momento inicial, e focando especialmente os países ocidentais, verificou-se um encerramento generalizado de um conjunto significativo das atividades económicas devido ao confinamento da população que não trabalhava em áreas de bens essenciais (como a saúde e o abastecimento de bens essenciais, entre outros). Progressivamente, o confinamento foi dando lugar à "reabertura da economia" e à retoma do trabalho presencial, sobretudo em setores que não são passíveis de funcionar de outro modo. Se num primeiro momento de "fim do confinamento" os números de infetados pela Covid-19 estavam efetivamente em diminuição, num segundo momento situado no final de agosto e no mês de setembro deste ano, em que os números de infetados aparentam estar novamente a subir, poucos são os países que operaram um novo confinamento geral, pelo menos nos moldes rígidos do 
primeiro. Tal deve-se a uma gestão do risco, sobretudo entre os riscos de saúde e de aumento de infeções e os riscos económicos que um segundo confinamento acarretaria.

A pandemia ocasionou um panorama de isolamento social que transformou a vida de um momento para o outro, colocando alguns indivíduos numa situação vulnerável para lidar com as circunstâncias atuais, suscitando uma situação de desigualdades acrescidas perante as consequências da Covid-19. $\bigcirc$ agravamento das desigualdades sociais e algumas destas novas posições sociais e as consequências que daí advém, como o desemprego ou a adaptação mais ou menos difícil ao teletrabalho, são bastante condicionadas pelas condições sociais que os indivíduos têm, em termos de rendimento, de condições habitacionais, de escolaridade, de género, de capacidades linguísticas, entre outros. Porém, sendo a gestão do risco atual diferente, que impacto terá nas desigualdades sociais? ○ "fim do confinamento" envolve novos desafios pelo aumento da exposição ao vírus, mas quem serão os mais afetados? Será que aparecerão novas categorias em que aumentam severamente as desigualdades além das referidas previamente? $\bigcirc$ atual período de desconfinamento ainda é muito precoce para se realizar conjeturas sobre as consequências da nova gestão dos riscos, assim como da sua variabilidade entre países.

Por enquanto sabe-se que existem diversas consequências da paragem económica e do isolamento físico e social que foram abordadas nos capítulos deste livro e que permitem aferir que os mais vulneráveis tanto à infeção como a consequências sociais e económicas desta crise são os que já estavam numa situação de desigualdade social, tendo menos recursos e estando também mais expostos. Assim, condições de vida desiguais não só correspondem a riscos de infeção desiguais, como a formas desiguais de lidar com a pandemia e com as consequências desta. Esta evidência demonstra por si só que a pandemia Covid-19 ocasionou um panorama de aumento da reprodução das desigualdades sociais, que se concretizam em desafios em várias esferas do social, particularmente pelo seu exacerbamento que obstaculiza o desenvolvimento sustentável e o alcance de 
sociedades mais igualitárias. A pandemia veio descapacitar os indivíduos, impedindo-os de exercerem integralmente as suas liberdades, no sentido enunciado por Amartya Sen (Sen, 2003).

Referências bibliográficas

Beck, Ulrick (2015 [1986]), Sociedade de Risco Mundial - Em Busca da Segurança Perdida, Lisboa, Edições 70.

Bourdieu, Pierre (2010 [1979]), A Distinção - Uma Crítica Social da Faculdade do Juízo, Lisboa, Edições 70.

Cabral, Manuel Villaverde; Pedro Ancântara; e Hugo Mendes (2002), Saúde e Doença em Portugal, Lisboa, Imprensa de Ciências Sociais.

Caldas, José Castro; Filipe Lamelas; e Pedro Estêvão (2020), "Regresso ao trabalho? Participação dos trabalhadores na prevenção da covid-19 nos locais de trabalho", Políticas em análise, №4/abril de 2020, CoLABOR.

Costa, António Firmino (2012), Desigualdades Sociais Contemporâneas, Lisboa, Mundos Sociais.

Foucault, Michel (2018 [1975]), Vigiar e Punir, Lisboa, Edições 70.

IHRU [Instituto da Habitação e da Reabilitação Urbana] (2018), Levantamento

Nacional das Necessidades de Realojamento Habitacional.

Milanovic, Branko (2016), Global Inequality: A New Approach for the Age of

Globalization, Cambridge, Massachussetts, The Belknap Press of Havard University Press.

Silva, Pedro Adão; Renato Miguel do Carmo; Frederico Cantante; Catarina Cruz; Pedro Estêvão; Luís Manso; e Tiago Santos Pereira (2020a), Trabalho e Desigualdades no Grande Confinamento, (Estudos CoLABOR,N.02/2020), COLABOR.

Silva, Pedro Adão; Renato Miguel do Carmo; Frederico Cantante; Catarina Cruz; Pedro Estêvão; Luís Manso; Tiago Santos Pereira; e Filipe Lamelas (2020b), Trabalho e Desigualdades no Grande Confinamento (II) (Estudos CoLABOR, N.o3/2020), CoLABOR. 
Scambler, Graham (2012), Health inequalities, Sociology of Health and IIIness (34), n०1.

United Nations (2020), The Sustainable Development Goals Report.

Therborn, Göran (2013), The Killing Fields of Inequality, Cambridge, Polity Press.

Sen, Amartya (2003), "Development as capability expansion", em Fukuda-Parr et al. (eds.), Readings in Human Development, Oxford, Oxford University Press, pp.1-16 
Entrevista realizada a Inês Tavares e Ana Filipa Cândido no âmbito da rubrica "Um olhar sociológico sobre a crise Covid-19", publicada a 1 de julho de 2020.

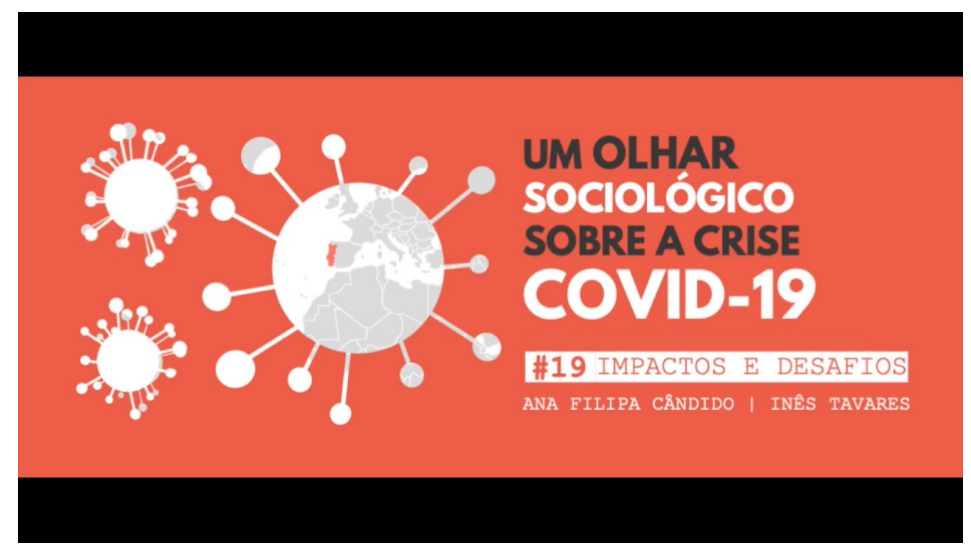




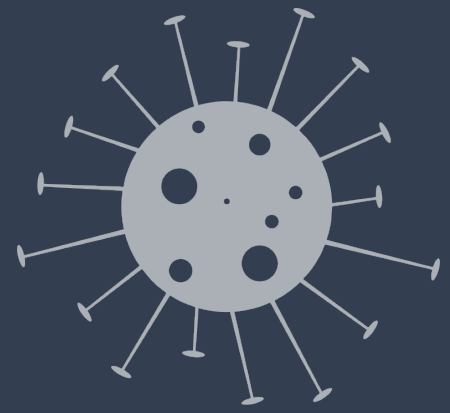

NESTE MOMENTO AS SOCIEDADES ATRAVESSAM UMA CRISE PROFUNDA E SINGULAR PROVOCADA PELA PANDEMIA COVID.
Q U

\section{U E}

\section{ESTAMOS A}
A IV ER
REPRESEN T A
U M A

19. 0

ANORMALIDADE Q UE N ÃO PODE ( N ÃO DEVE) TRANSFORMAR SE NO NOVO NORMAL. SE ISSO ACONTECER É A PRÓPIA NOÇÃO DE SOCIEDADE QUE PODE ESTAREM CAUSA.

DE MANEIRA A MELHOR COMPREENDERMOS OS IMPACTOS E AS
CONSEQUENCIAS
DESTA
CRISE
NAS
DESIGUALDADES

SOCIAIS, DESAFIÁMOS VÁRIOIAS SOCIÓLOGOIAS A REFLETIR SOBRE ESTA REALIDADE A PARTIR DO OLHAR ESPECIALIZADO. OS SEUS CONTRIBUTOS, PRIMEIRO EM FORMA DE ENTREVISTA E AGORA EM REGISTO ESCRITO, AJUDAM-NOS A INTERPRETAR E A DAR SENTIDO A TODA ESTA INCERTEZA E INSTABILIDADE QUE PARTILHAMOS COLETIVAMENTE.
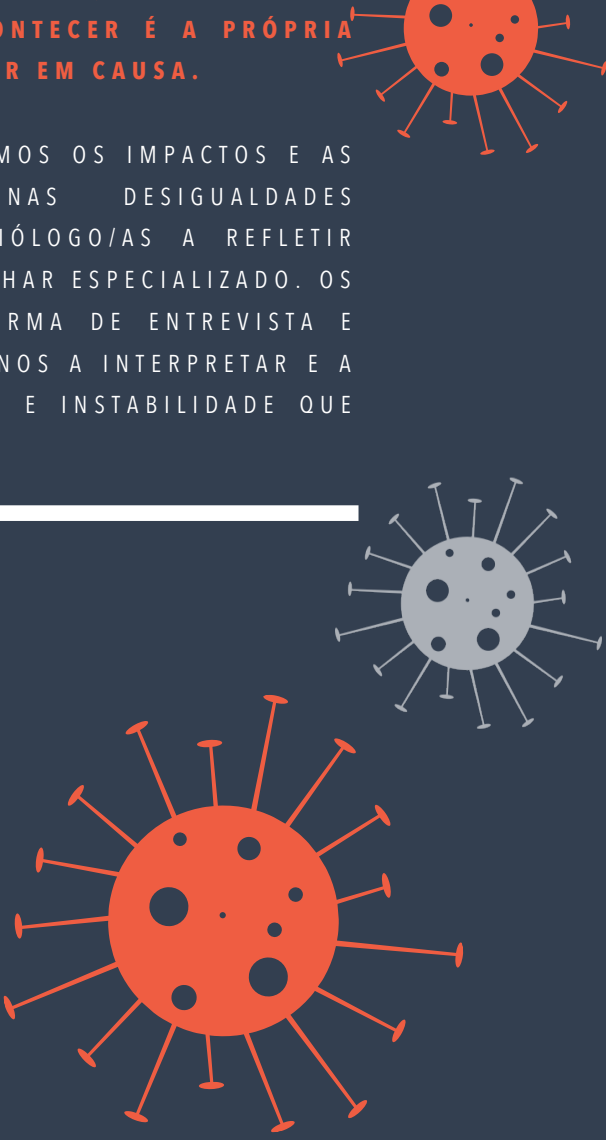